Historic, Archive Document

Do not assume content reflects current scientific knowledge, policies, or practices. 



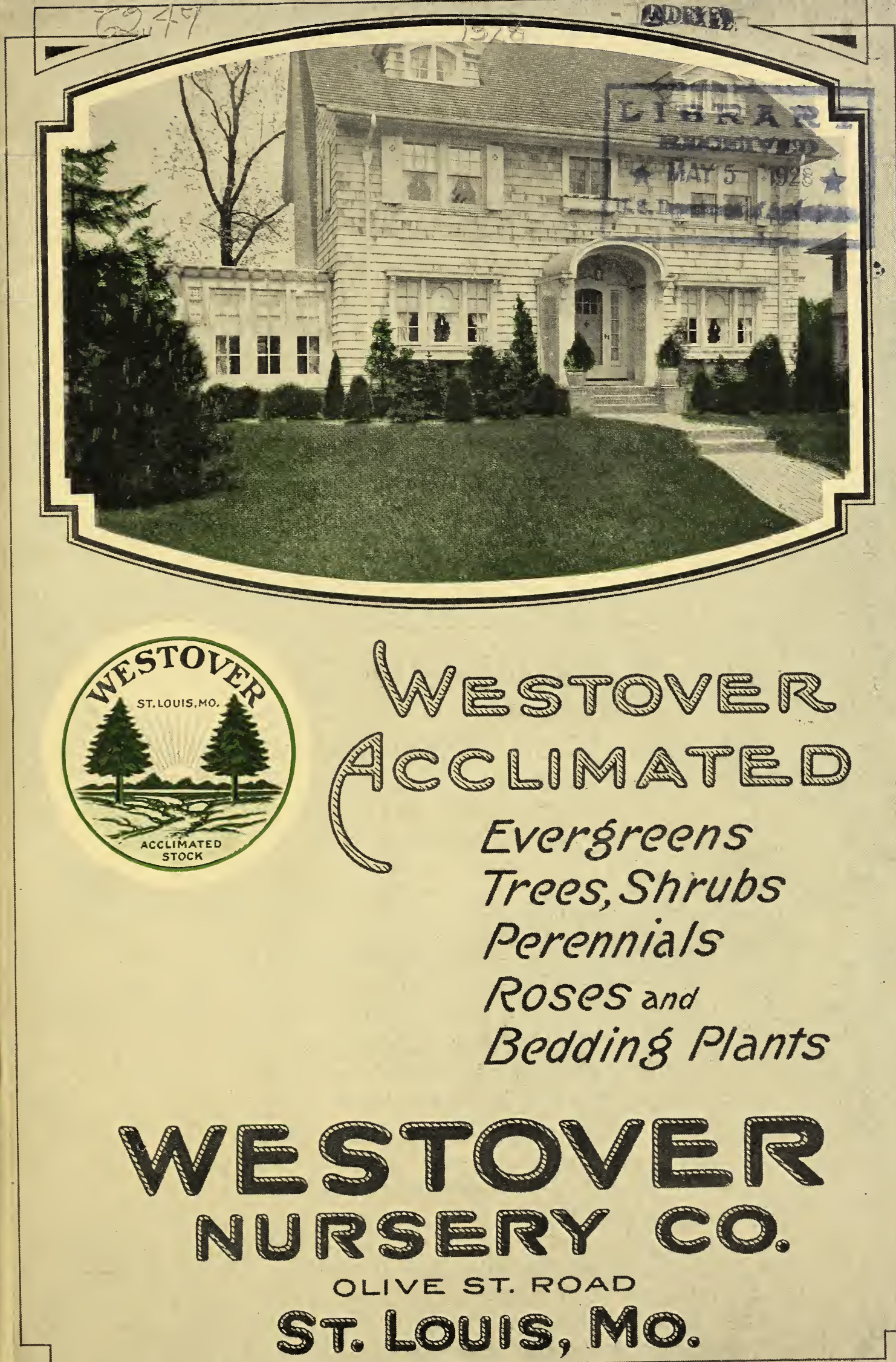




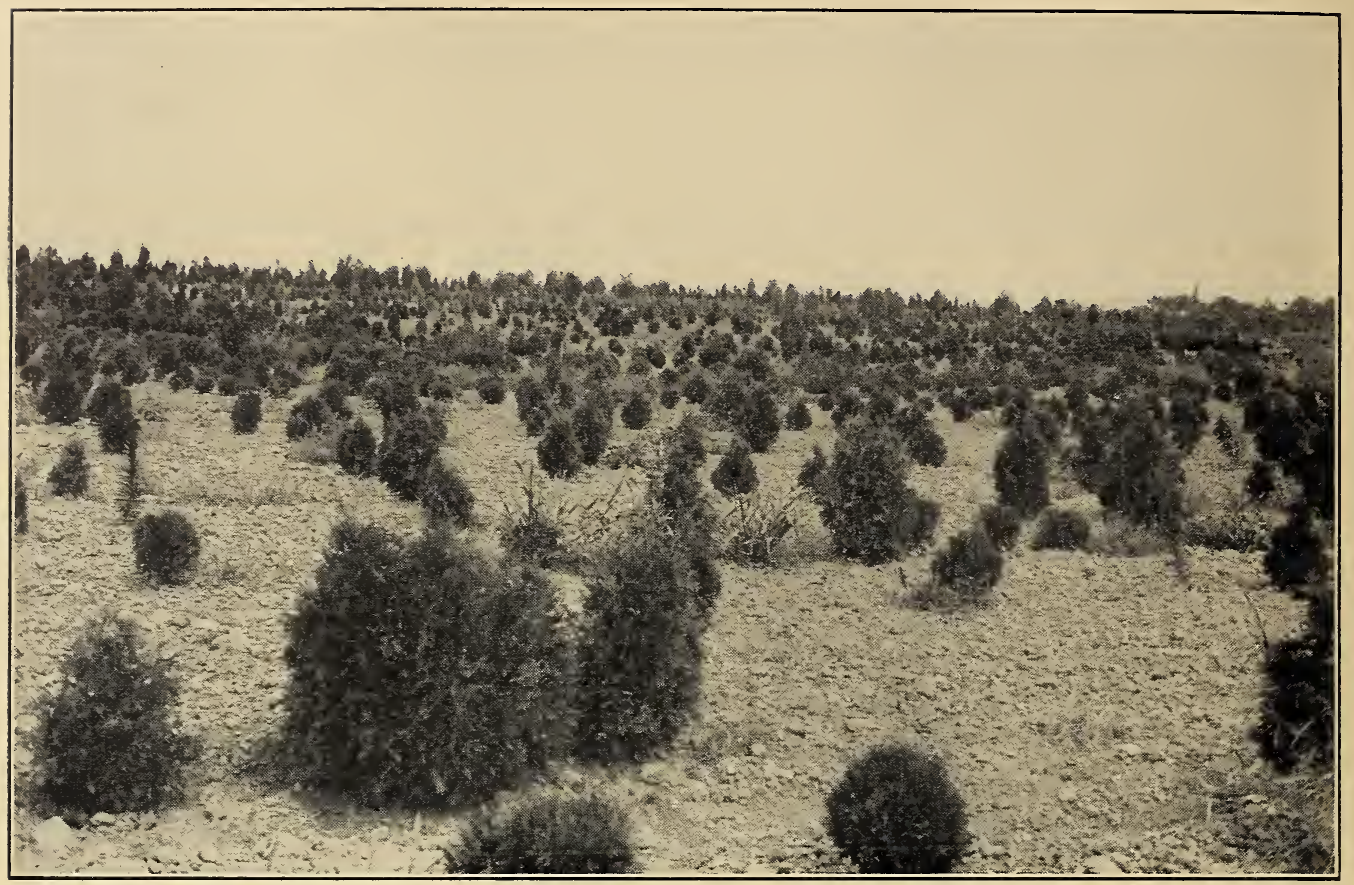

Evergreen Hill-A view of Westover Evergreens

\section{$\boldsymbol{F A L L}$}

1927

\section{Westover Acclimated Evergreens,}

$\mathrm{T}$ Westover Nursery - a garden spot spreading over sixtyone cul-
tivated acres of rich, heavy clay soil laying to either side of the
paved highway of Olive street road, west of north and south road, in Clayton, Mo., skirting St. Louis-we raise practically every one of the thousands of plants illustrated, described and priced in this catalog - Evergreens, Trees, Shrubs, Perennials, Bedding Plants, Roses and Fruits. Besides, we have a hundred and three acres on Tree Farm No. 2 - some seven miles west on the same road, in growing nursery stock. IVe sell direct to the home owner and landscape architect.

Westover Nursery Company is the originator of acclimating nursery stock that may best be defined as follows:

- what is true of men is equally true of trees and shrubs, and the human characteristics of nursery stock may best explain our use of the word "acclimated."

-it is no more possible for a thin-blooded negro from the South to withstand the rigors of our winter climate without protection from the cold than it is for a Laplander, raised upon a diet of tallow and grease, to survive one of our sweltering summers without protection from the heat. 


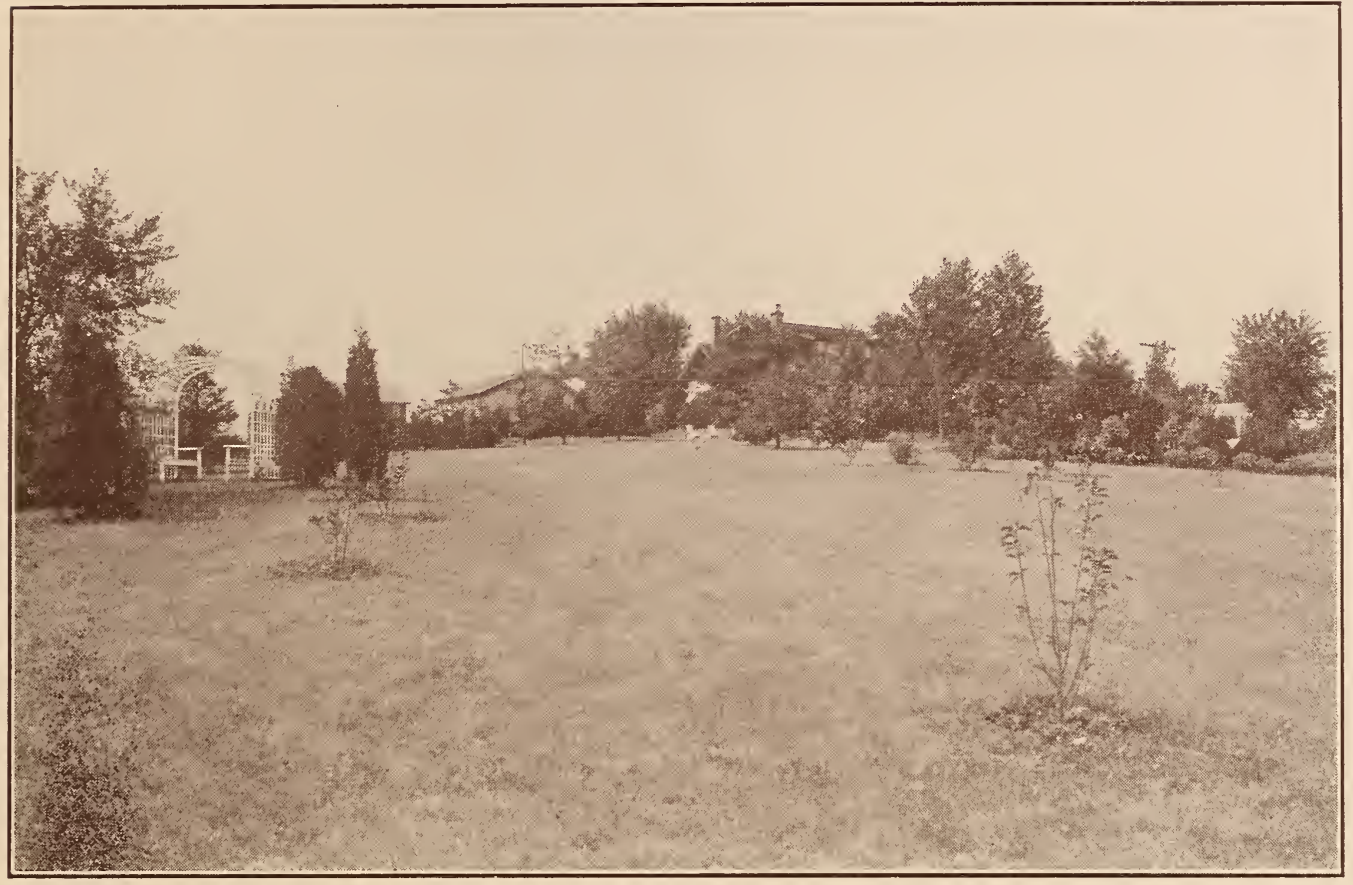

A view of display grounds at Westover Nursery

\section{Trees, Shrubs, Perennials, Roses ${ }_{1928}^{\text {SPRING }}$}

- conversely, you could not expect trees and shrubs grown under the ideal conditions of the East, with plenty of moisture, to thrive without protection by shade in summer, and heavy mulching in winter.

This the tender plants get at Westover's-hence the significance of the term "acclimated," and having developed under careful nursing a local root and twig growth, this young, hardy stock can be depended upon to grow, thrive and develop like the southern negro, whose blood has become thick, and the Laplander, whose blood has become thin.

Westover Nursery was started in 1916 by its present owners of practical and scientific nurserymen, who recognized the long felt need of a nursery in this section, where people could obtain every variety of plant suitable to this locality. The nursery began operation on a small tract of thirty acres, and has in a short span of ten years developed into a nursery of a hundred and sixty-four acres, with 47,500 feet of greenhouses and cold frames.

The founders realized full well that this locality was not the best suited for growing plants profitably, owing to our short growing season 


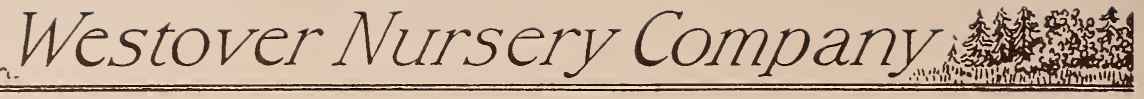

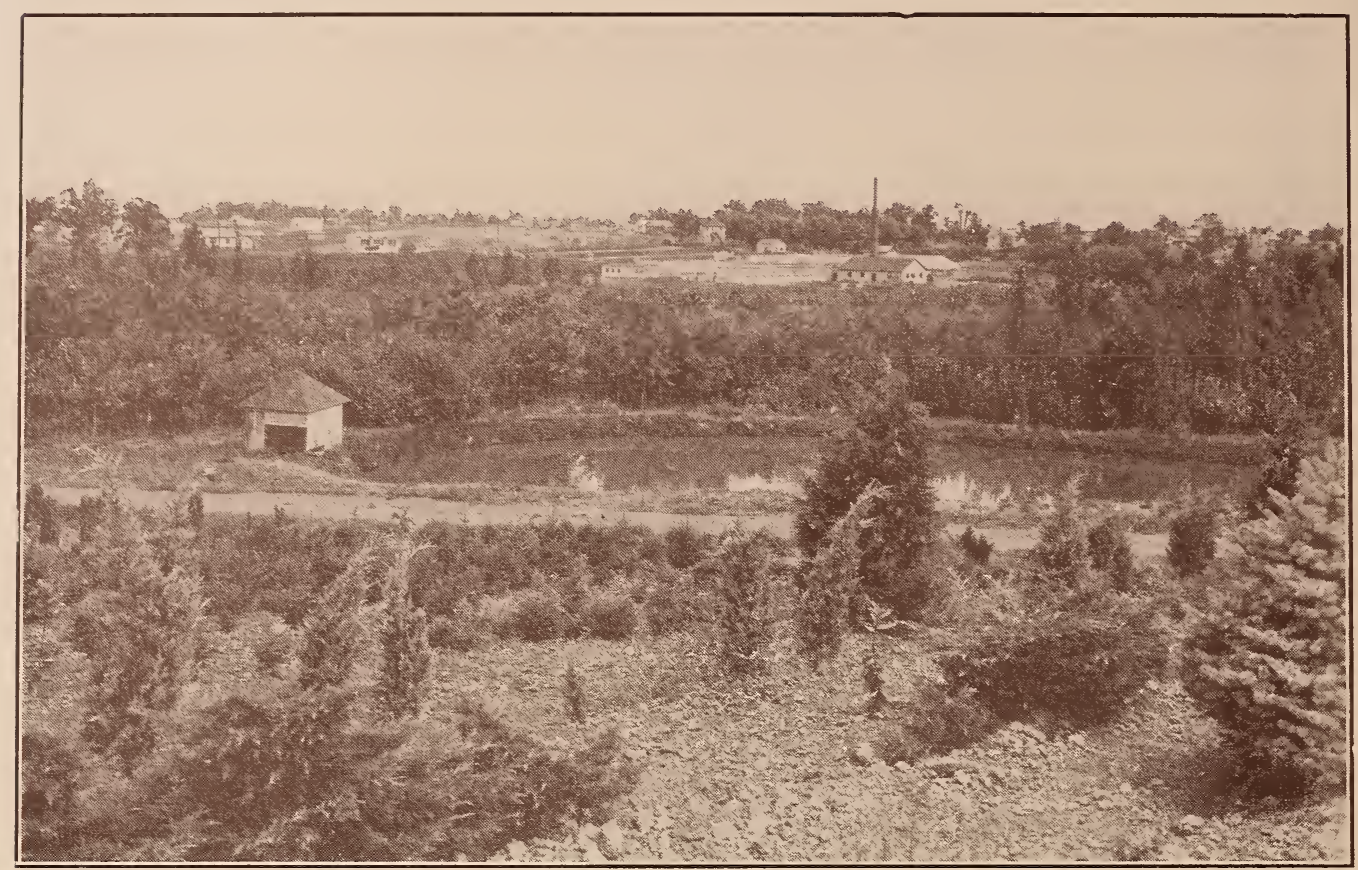

A view taken from Evergreen Hill, showing Lake and Shade Trees in foreground and Greenhouses in distance.

and otherwise unfarorable climatic conditions. Still, they reasoned that just as soon as people came to the realization that plants grown in this section would do better for them than those grown in far away localities, where soil and climatic conditions were more favorable to fast growth, they would gladly pay a little more for plants grown here. And so we attribute our marked success to the excellent results obtained with Westorer acclimated stock.

True, as our thousands of customers know, it does cost more to produce stock in this section, the sturdiness of our plants and the record of their growth more than offsets the price charged for stock grown in more farorable climate. We prefer to lose an order rather than to sell a plant which we know would not do well under conditions which surround it.

The filling of your first order is to us merely an introduction to your good will and your continued patronage.

As we do not employ agents or solicit business from any source other than our catalog, we take particular pride, and attribute our rapid growth to "repeat" orders, and from orders received from friends recommended by our customers who know our methods of doing business. 


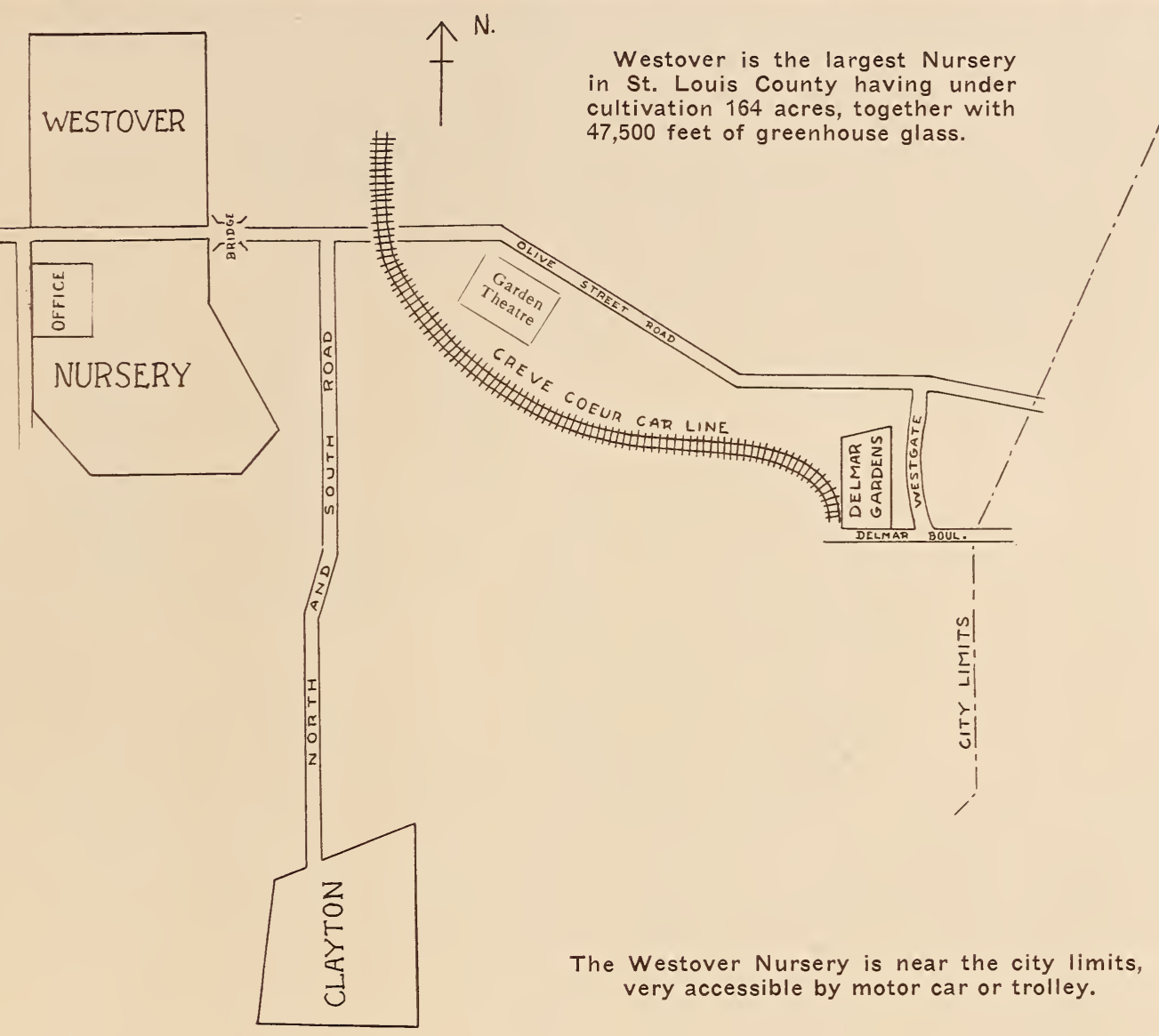

\section{Visitors Are Welcome}

The public is cordially invited to visit our nurseries and greenhouses. Visitor's are not annoyed by solicitations of a commercial nature.

\section{Westover Display Grounds}

For the benefit of our customers we have planted a large portion of our grounds near our office, where may be found practically every variety of plant we grow, and where rou may obtain ideas as to the desirability of the rarious specimens, by seeing the plants in bloom.

\section{General Directions}

Location-Our main office and display grounds are on the Olive Street Road just west of the north and south road; one mile west of Creve Coeur car line. Dartsdale Bus service which leares end of Delmar Olive car every hour goes direct to nursery. 


\section{Westover Nursery Company}

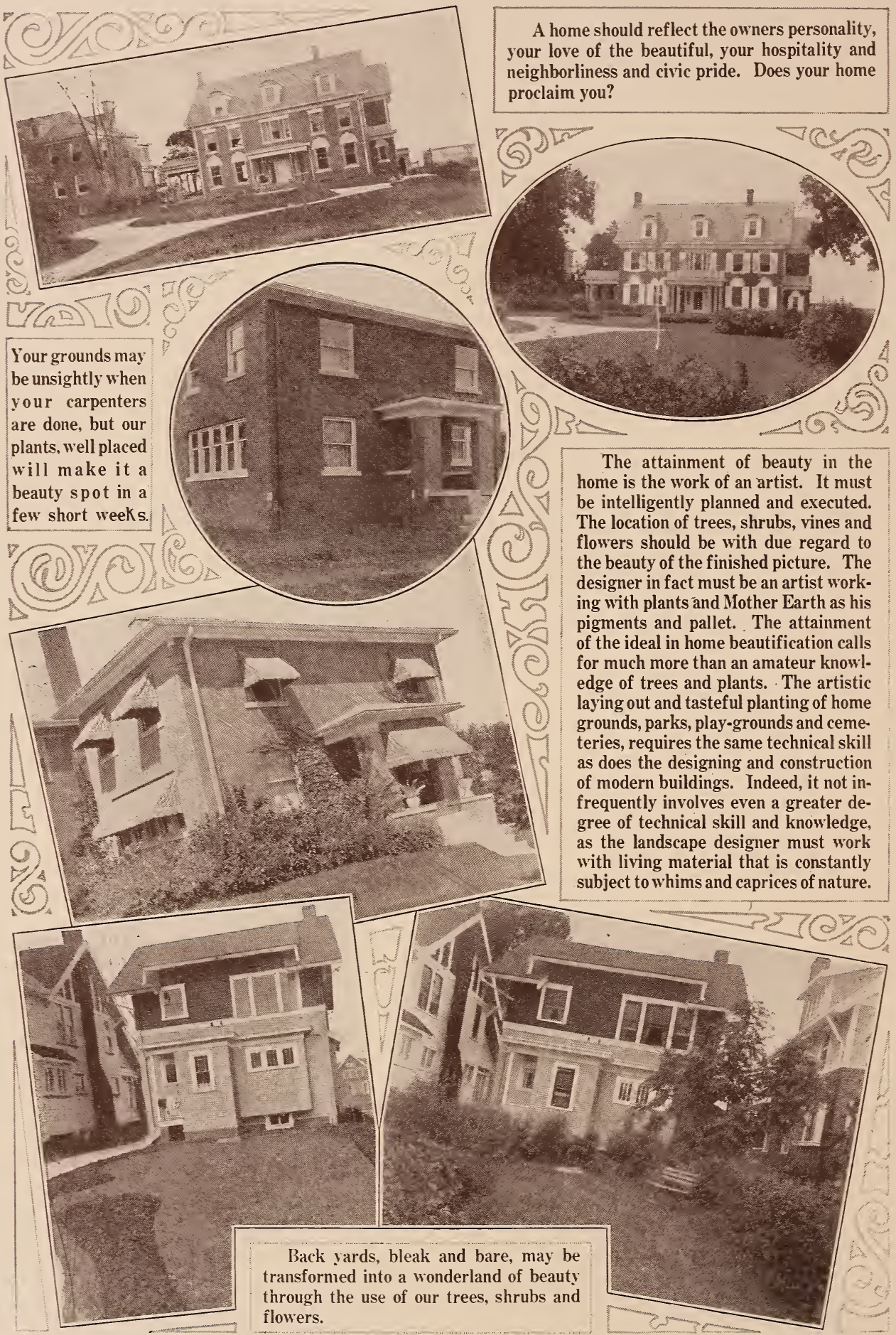




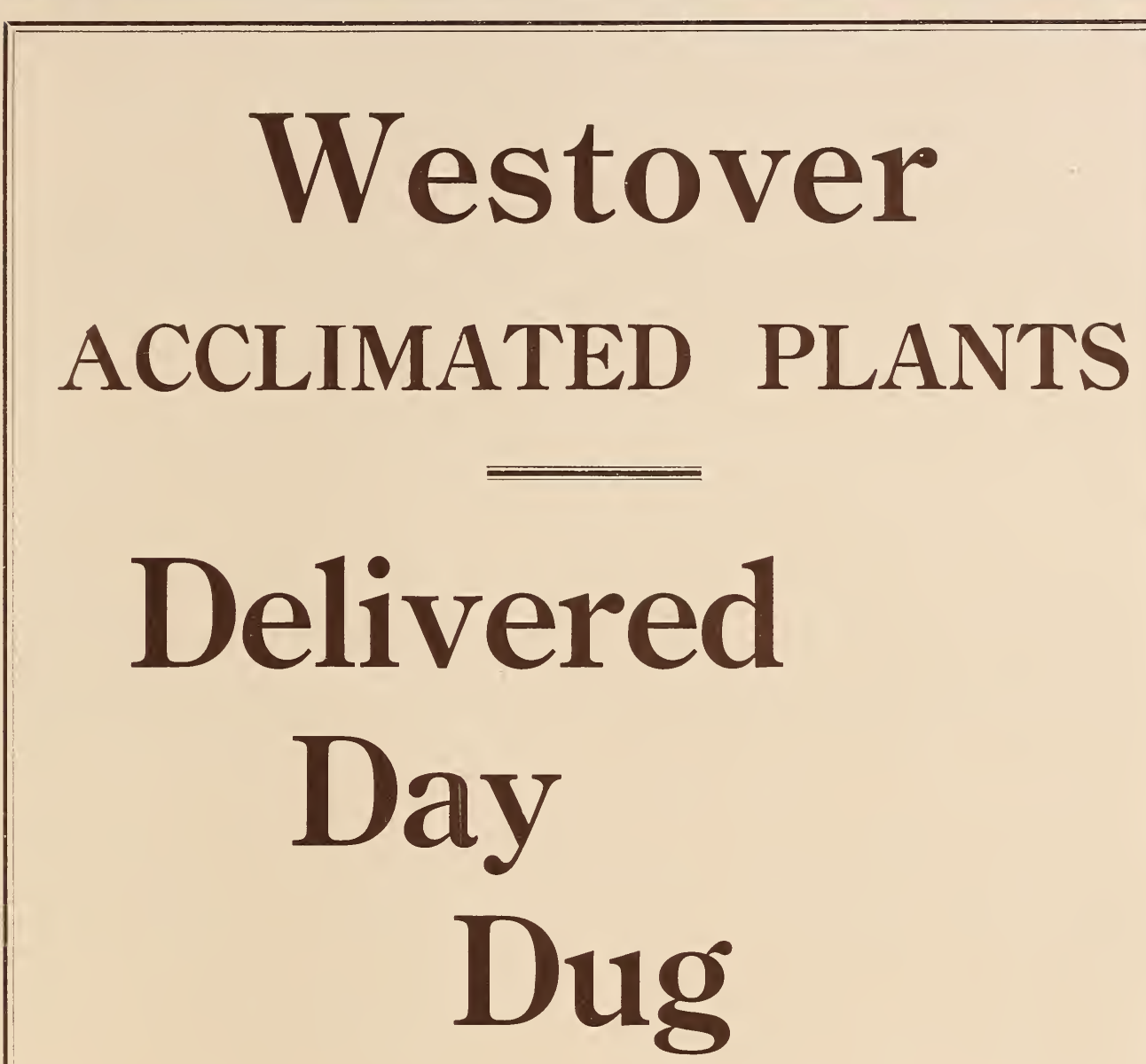

\section{ACCLIMATED PLANTS}

Delivered

The above is not merely a slogan, but is further reason why "Westover Acclimated Plants" are worth more than plants sold by various jobbers who do not have proper storage facilities to protect the roots of plants after they are dug, as it is most important to see that the roots of plants are covered with moisture retaining material, or better still to heel them in immediately after being dug.

\section{P. S.-PLANT SOMETHING}




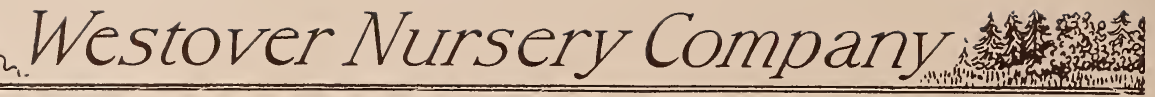

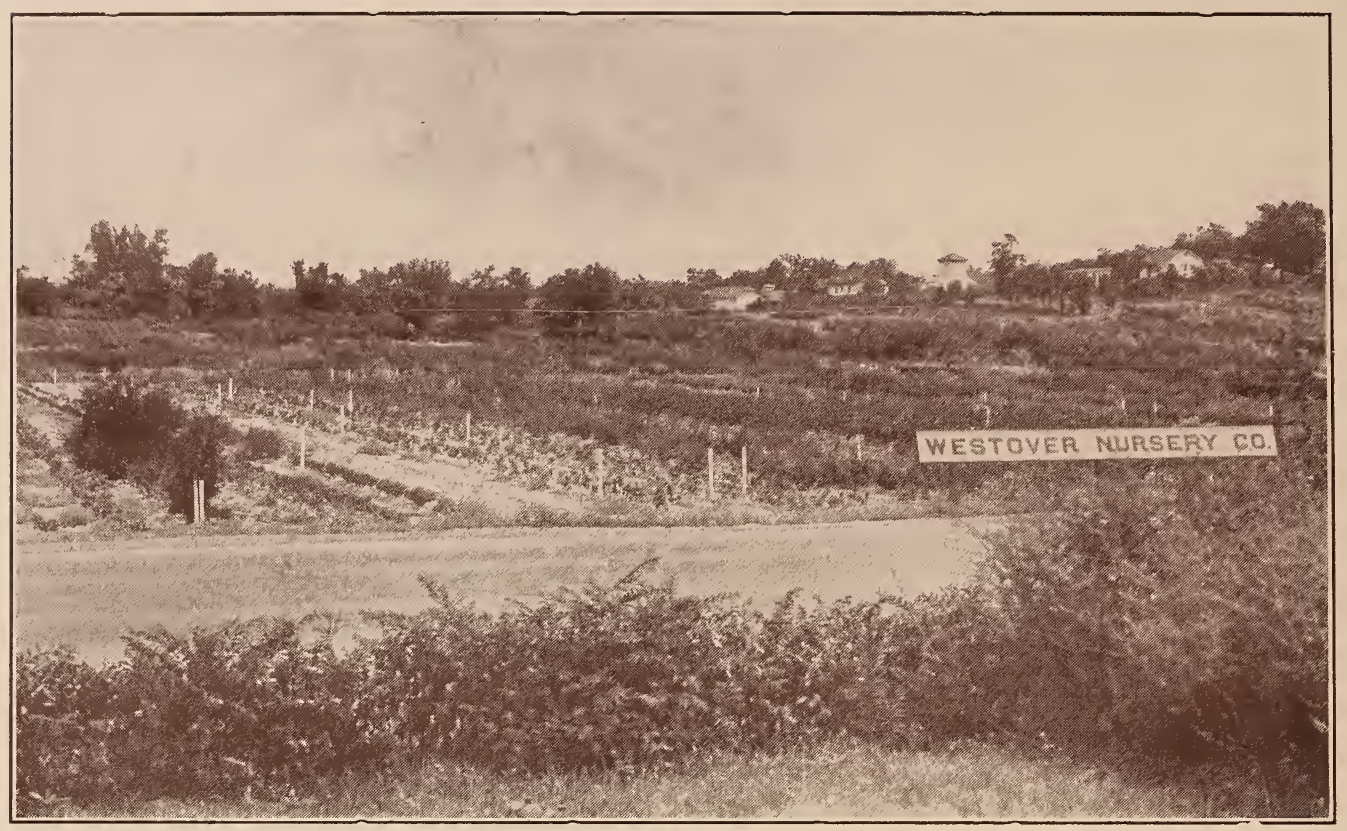

A view taken from display grounds showing field of Ornamental Shrubs in foreground, showing Barns and Bunkhouse in distance.

\section{Prices}

Prices noted in this catalogue are net, f. o. b. St. Louis, and are accepted subject to prior sale and loss caused by drought, fire, hail or other causes beyond our control.

Prices in this catalogue cancel all previous lists and quotations and are subject to change without notice. Prices do not include packing of shipping orders which will be charged for extra at cost, but does include delivery within the city limits of St. Louis. Stock specially selected by customers at the Nursery will be charged according to the value of the trees chosen irrespective of catalogue list price.

RATES: 1 to 4 of the same size and variety take each rate.

5 to 25 of the same size and variety take 10 rate.

25 to 100 of the same size and variety take 100 rate.

\section{Terms}

Cash must accompany all orders to insure prompt shipment.

Parties desiring credit must furnish satisfactory references and allow sufficient time for investigation. When credit is extended, invoice will be mailed on day of shipment and payment must be made on the 10 th of the month following date of invoice.

No orders accepted for C. O. D. shipment.

\section{Guarantee}

We are vitally interested in the success of everything purchased from us. We will cheerfully advise you what, where and when to plant. We will advise you how to care for stock after planting. All products sold by us are of selected quality, and when promptly and properly planted and given ordinary care, should thrive under the severe climatic conditions peculiar to this section, where they are grown.

We do not guarantee stock to grow, or results in any way. No complaint will be entertained that is not made immediately upon receipt of stock.

There are so many causes for failure over which we have no control that we can assume no responsibility after stock is delivered in good order. Poor soil, unfavorable weather, ignorant or careless culture, all contribute to failure and are beyond our control.

Our warranty insures the purchaser obtaining healthy, vigorous plants true to name.

\section{Landscape Contracting}

We do not execute any planting outside of our grounds, as this important work is a profession quite apart from the growing end of the industry, but we are in close touch with all the leading landscape architects and gardeners and will gladly furnish customers with the names of reliable specialists in this line, who are prepared to estimate on contracts of any magnitude.

\section{State Inspection}

The Westover Nurseries are inspected at frequent intervals during the year by the Nursery and Orchard Inspection Service of the Department of Agriculture of the State of Missouri; a Department Certificate of Inspection, attesting the fact that our nurseries are free from parasitic growths and harmful insects, accompanies each shipment.

"We are Members American Association of Nurserymen: All quotations, prices, contracts and grading both for purchase or sale are based on HORTICULTURAL STANDARDS adopted by this Association, June, 1923." 


\section{Transplanting Directions}

\section{Preparing the Soil}

No one thing is of more importance to the ultimate development of plants than thorough preparation of the soil. When the natural soil is of a poor quality, replace to a depth of about two feet with a good grade of. loam. For a single plant, dig out a hole twice as large as is really necessary to contain its roots. When group plantings are to be made, dig out the whole area. Well rotted manure may be mixed into the soil to good advantage, but always avoid the use of fresh manure in contact with roots of a plant. The problem of drainage must be considered. If the natural drainage is poor, artificial drainage must be made.

\section{Planting}

At the time of planting, most plants need a little shaping, both of tops and roots. Since a portion of the root system has been cut away in digging, a corresponding portion of the top should be removed. It is best to retain the general shape of the plant, cutting away any weak or injured branches and about one-third of the previous year's growth from the end of each branch. Evergreens and stock dug with a ball of earth are exceptions. The root system should be examined and all split or bruised roots removed with a diagonal cut.

Be careful not to set the plant too deep, for injury is sure to follow. Place the plant a little deeper than the point at which it is to remain, and carefully spread out all the roots (plants dug with a ball of earth excepted), now shovel in the dirt until the roots are covered about two inches. Lift the plant up and down until the soil settles in well and no cavities remain. Throw in more earth and with a blunt stick work well in under the roots. Press down the soil with a firmer or the foot, beginning at the center of the plant and working out. When the hole is filled, to within three or four inches of the top, pour in two or three pailfuls of water. Allow this to disappear, and then fill the hole, leaving a slight depression around the plant.

In planting evergreens or other plants dug with a ball of earth, care should be taken to prevent breaking the ball. Place the plant in the hole so that the top of the ball is not more than one inch below the level of the ground. Put in enough soil to hold the plant firmly in place. Do not remove the burlap covering from around the ball, but rip it at the top and down the sides in about three places and crowd to the sides of the hole. Fill up as described above.

\section{Watering and Mulching}

After a plant has been set in the ground it should be mulched with manure, leaves or lawn clippings to prevent evaporation of the soil's moisture. When mulching is unsightly or not practical, occasional watering and frequent loosening of the soil serves a similar purpose. The ground around plants should never be allowed to become dry and if there is not sufficient rain, artificial watering should be supplied.

\section{After Care}

It is our earnest desire to assist all lovers of trees and other plants, from a practical standpoint by helping them to attain desired results. Many plantings never receive the after care they require. This applies more especially to home foundation and other intensive plantings of both evergreens and shrubs. Such plantings are often massed with the plants placed close to one another to produce immediate effects. Unless these plantings are trimmed consistently from season to season, they soon lose their original attractiveness and become ragged and overgrown, whereas if they are given proper care, they improve in appearance from season to season and can be kept within any required limitations.

Deciduous shrubs should be pruned so as to remove a portion of the old wood each year, saving the new growth. By this method each plant is entirely renewed every few years. Judgment must be used in pruning so that as much of the blossoming wood as possible will remain. This refers especially to Spireas, Forsythia, Japan Quince, etc. Such shrubs as Hydrangeas, Altheas and most roses, bloom on the new growth and are improved by pruning before the spring growth begins.

A little mid-summer pruning is often advantageous, especially where plants are becoming unshapely or are overgrown. Massed plant. ings of evergreens need careful pruning and shaping each season, otherwise the stronger growers will overcrowd the others. This trimming can be done to advantage just before the new growth starts in the spring.

These brief instructions are only intended to give a few simple pointers. Write to us freely if you have any garden problems which are causing you anxiety. With our wide experience it is probable that we can help you.

\section{Protection}

It is advisable to stake a newly planted tree in locations where the wind blows severely. The continued shaking of the tree prevents the little roots from getting a hold in the soil and often results in failure of a plant to grow.

Suitable guards should be provided for all trees planted where exposed to horse bites, hub scars and similar injuries.

\section{Westover-Delivers Day Dug.}




\section{Westover Nursery Company i}

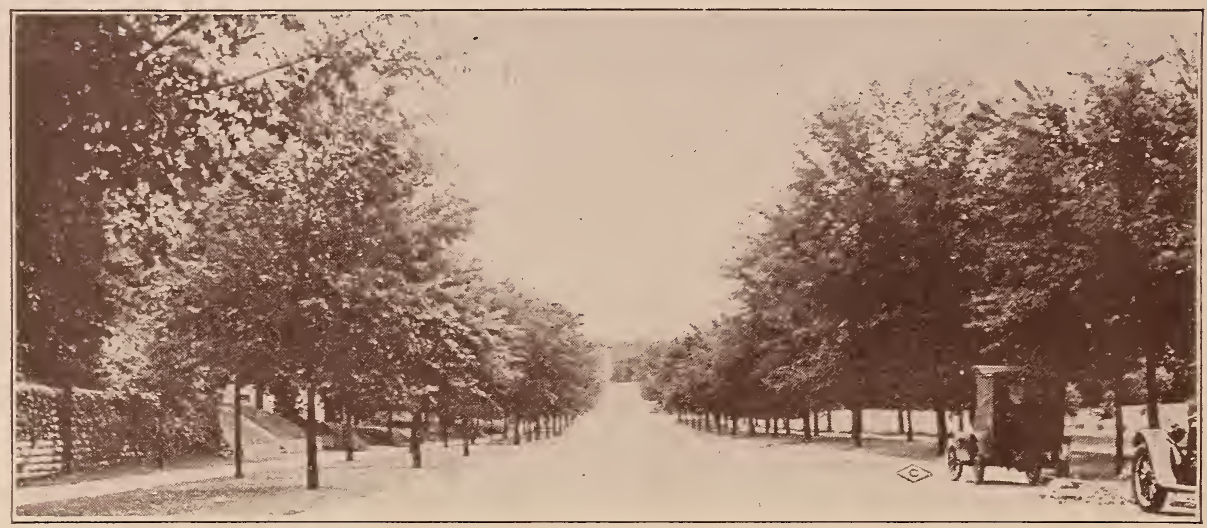

\section{Deciduous Trees}

T THERE anything more lovely than the continual change of trees with the season? Emerging from the cold breath of King Winter, into the soft, warm breezes of Springtime, the swelling buds open into bashful blossoms-retiring perhaps because of their precipitation into a new world, but none the less beautiful. With summer, their delicately expanding leaves take on a deep, rich greenand a few months later, the evolution into Autumn, with a myriad of gorgeous hues, is complete.

The trees we offer are produced under the most favorable conditions. They are thrifty, vigorous specimens, with great fibrous roots. Many of them are seedlings-some are reproduced by budding or grafting. All are transplanted at least two or more times.

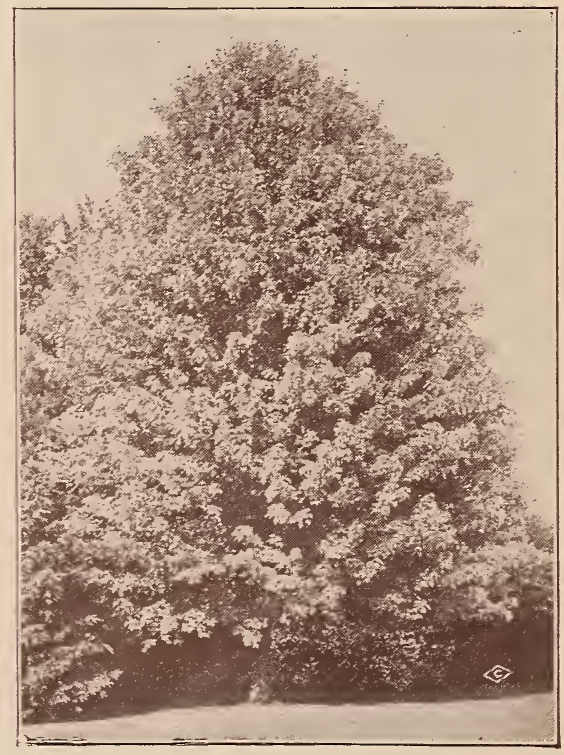

Silver or Soft Maple
(Clpr. is an abbreviation for Diameter)

ACER Dasycarpum-Silver or Soft Maple.

This is the quickest growing and largest of the maples. It is especially delightful on the lawn or park, where its broad, spreading head is given plenty of room.

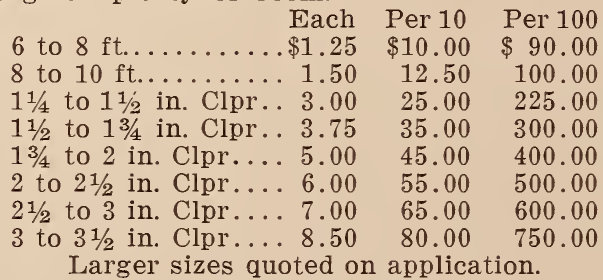

\section{A. Dasycarpum Pyramidalis-Pyramidal} Silver Maple.

This variety can only be produced by grafting or budding. It is a fast growing tree, low branched and pyramidal in growth.

Specimens............. $\$ 15.00$ to $\$ 25.00$

\section{A. Ginnala-Amur Maple.}

This is a beautiful tree, growing to medium height, low branched and bushy. Brilliant autumnal coloring.

4 to $5 \mathrm{ft}$. specimens........ \$5.00 $\$ 40.00$ 


\section{A. Dasycarpum Wierii-Wier's Cut-Leaved} Maple

The Wier Maple is a great deal like the Silver Maple. However, it is more upright in habit of growth, with pendulous branchlets; leaves deeply cleft and shredded. Grows very fast and makes a very shapely tree.

Sizes and prices quoted on request.

\section{A. Platanoides-Norway Maple.}

This is a beautiful, round topped tree. The foliage is a deep, rich green and its shape closely resembles that of the Sugar Maple.

Each Per 10

5 to $6 \mathrm{ft} . \ldots \ldots \ldots \ldots \ldots \ldots . \ldots 3.00 \$ 25.00$

6 to $8 \mathrm{ft} \ldots \ldots \ldots \ldots \ldots \ldots \ldots \ldots 4.50 \quad 40.00$

8 to $10 \mathrm{ft. \ldots \ldots \ldots \ldots \ldots \ldots \ldots .5.50 \quad 50.00}$

Larger sizes quoted upon request.

\section{A. Saccharum-Sugar Maple.}

The Sugar Maple has always been the grandest of all maples. It is a tall, stately tree and of the greatest beauty. Wonderful tones of orange and lemon characterize its leaves in the Autumn. Particularly fine for planting as a specimen on the lawn. It is however very slow growing.
8 to $10 \mathrm{ft} . . \ldots \ldots \ldots \ldots \ldots \ldots 4.0 \ldots$
$11 / 4$ to $11 / 2$ in. Clpr........ 4.50
$\$ 35.00$
$11 / 2$ to $13 / 4$ in. Clpr............ 5.50
40.00
2 to $2 \frac{1}{2}$ in. Clpr.......... 7.50
70.00

Per 10

AESCULUS Hippocastanum-Horse Chestnut. One of the finest of flowering trees-but of slow growth. Has white flowers in spikes or

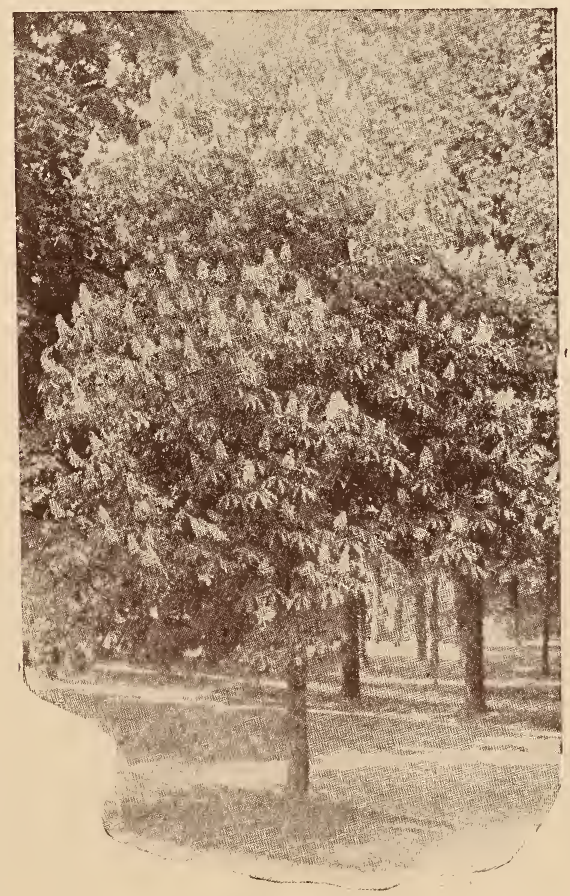

Horse Chestnut

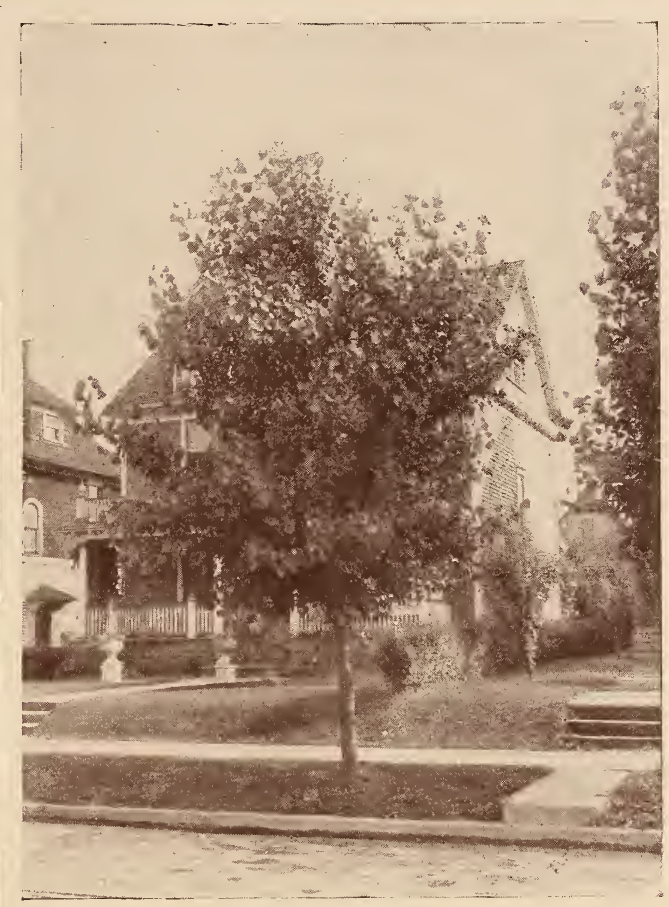

Norway Maple

panicles. Blooms to nearly middle of May. Each Per 10

$11 / 4$ to $11 / 2$-in. Clpr..........\$4.50 \$40.00

$11 / 2$ to $13 / 4$-in. Clpr.......... $5.50 \quad 50.00$

\section{ALNUS Glutinosa-European or Common}

Alder.

A vigorously growing tree with dark green dull foliage. Valuable for planting in damp situations.

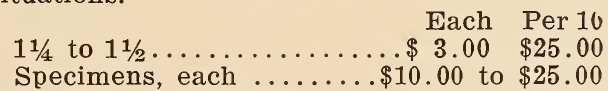

ARALIA-(See Shrubs).

BETULA Alba-European White Birch.

The beautiful white bark of this tree makes it very popular for lawn planting. Very upright in habit, reaching 60 feet or more.

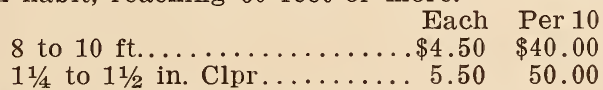

B. Alba Pendula Laciniata-Cut-Leaved Weeping Birch.

An elegant, erect tree, with slender drooping branches and fine cut leaves. White bark.

Each Per 10

6 to $8 \mathrm{ft} . \ldots \ldots \ldots \ldots \ldots \ldots . \ldots 5 . \ldots \ldots+\ldots 50.00$

8 to $10 \mathrm{ft} . \ldots \ldots \ldots \ldots \ldots \ldots . \ldots \ldots$. $7.50 \quad 70.00$

B. Nigra (Rubra)-Black Birch.

Excellent for screen or windbreak. Grows tall and graceful. Recommended by Shaw's Garden for planting in the city.

Each Per 10

$21 / 2$ to 3 in. Clpr..........\$5.00 \$45.00

3 to $3 \frac{1}{2}$ in. Clpr.........6. $6.00 \quad 50.00$ 


\section{Westover Nursery Company}

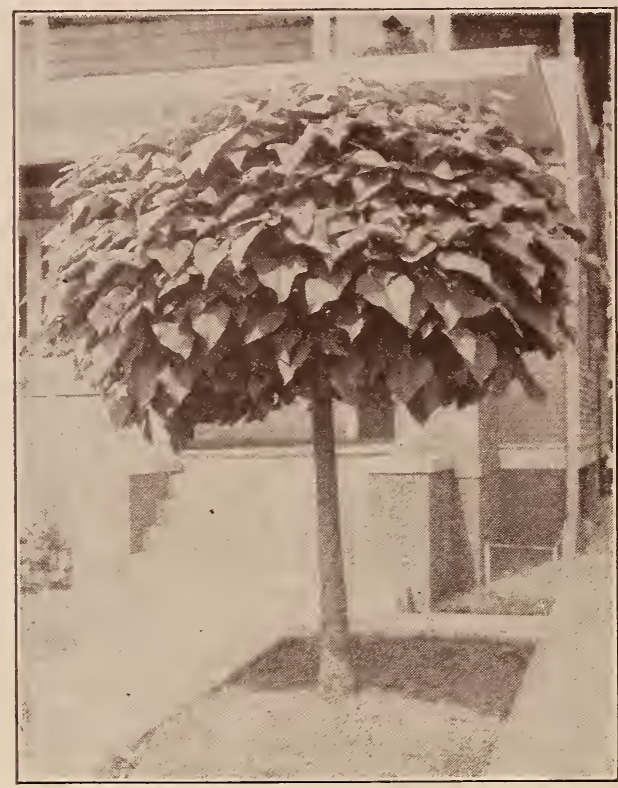

Catalpa Bungei

B. Papyrifera-Paper or Carve Birch.

A graceful tree with loose bark of a buff color.

Each Per 10

$11 / 2$ to $13 / 4$ in. Clpr........\$4.00 \$35.00

$13 / 4$ to 2 in. Clpr........... $5.00 \quad 45.00$

2 to $2 \frac{1}{2}$ in. Clpr.........6.00 50.00

\section{B. Populifolia-Gray Birch.}

A small graceful tree with smooth white bark. Thrives in poor dry soil better than any Birch.

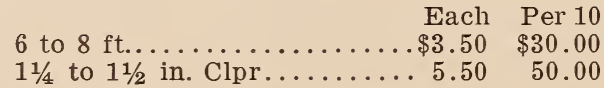

\section{CARPINUS Caroliniana-Horn Beam.}

Shrubby tree, good foliage. Valuable for screen or hedge. Can be sheared any shape.

Each Per 10

4 to $5 \mathrm{ft} . \ldots \ldots . . \$ 4.50 \$ 40.00$

Specimens B. \& B.......\$15.00 to $\$ 25.00$

\section{CATALPA Bungeii-Chinese Catalpa.}

This tree is better known as the Umbrella Catalpa. The branches form a globe shaped head, at the top of a straight stem averaging five feet in height. Leaves are very large, dark green and heart shaped. This is one of the most popular trees on our list and is particularly desirable for formal effects.

Each Per 10

2 year heads...........\$2.50 \$22.50

3 to 4 year heads......\$3.50 to $\$ 5.00$ each

\section{Speciosa-Western Catalpa or Indian Beam.}

In June, this rapid growing tree of very erect form, blossoms forth with large white llowers.
As a flowering tree it is equal to the less hardy Horse Chestnut. It is especially adaptable for fence post planting and timbers for general use.

Each Per 10

$11 / 2$ in. Clpr............\$2.75 \$25.00

$13 / 4$ to 2 in. Clpr..................... $3.00 \quad 27.50$

2 to $2 \frac{1}{2}$ in. Clpr........... $3.50 \quad 30.00$

$21 /$ to 3 in. Clpr..........4. $4.00 \quad 35.00$

\section{CELTIS Occidentalis-Hackberry.}

This very desirable shade tree thrives almost everywhere. When other trees have failed, try the Hackberry. Resembles the elm in appearance.

$11 / 4$ to $1 \frac{1 / 2}{2}$ in. Clpr........ $\$ 3.00 \quad \begin{aligned} & \text { Pach } \text { Per } 10 \\ & \$ 25.00\end{aligned}$

CERCIS Canadensis-Red Bud or Judas Tree.

The lovely pink, pea-shaped blossoms of this beautiful tree lend much cheerfulness in the spring. It is a native woodland beauty.

$\begin{array}{rrrr}4 \text { to } 5 \mathrm{ft} . \ldots \ldots \ldots \ldots . & \text { Each } & \text { Per } 10 & \text { Per } 100 \\ 5 \text { to } 6 \mathrm{ft} . \ldots \ldots \ldots \ldots & \$ 1.50 & 12.50 & \$ 90.00 \\ 6 \text { to } 8 \mathrm{ft} . \ldots \ldots \ldots \ldots & 2.00 & 15.00 & 125.00\end{array}$

\section{CHIONANTHUS-(See Shrubs).} CORNUS Florida-White Flowering Dogwood.

Of all the spring time bloomers, this small tree is one of the lovliest. The conspicuous white petal-like bracts, which are an inch broad, give the flowered clusters a charming loveliness.

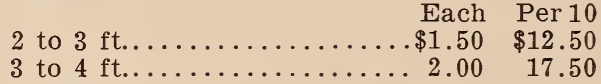

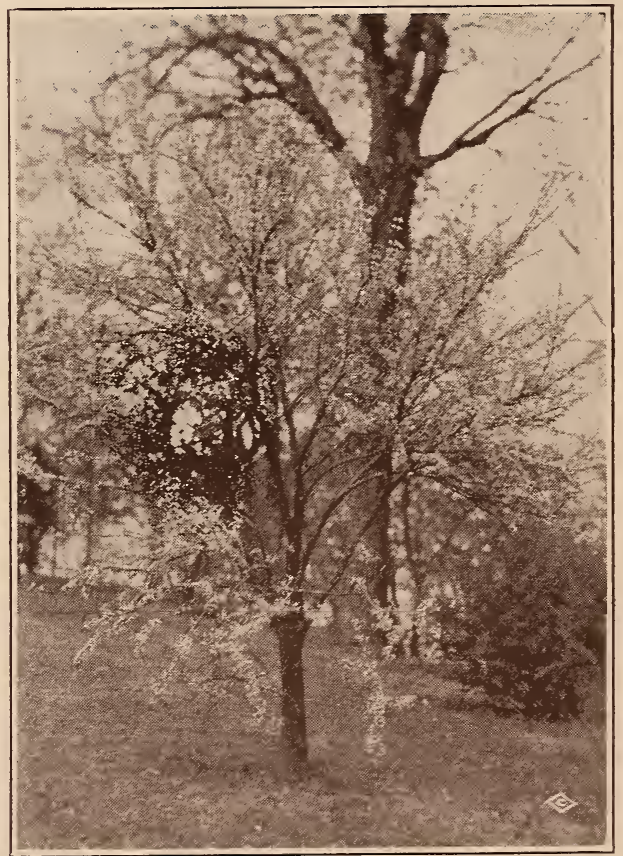

Red Bud or Judas Tree 

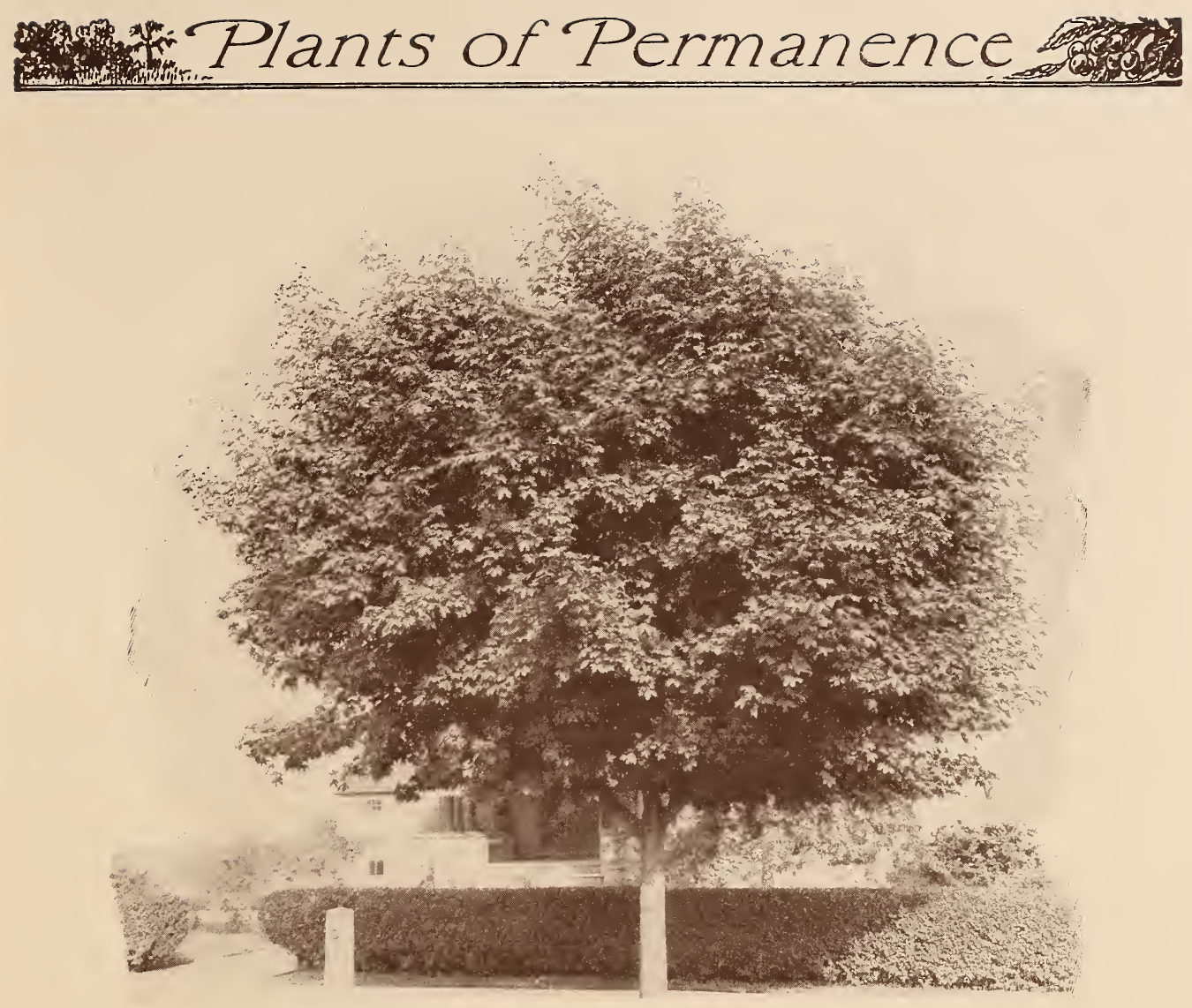

Hard Maple

\section{CRATAEGUS Coccinea-Scarlet Fruited Thorn.}

This beautiful tree-like shrub very often attains a height of fifteen feet and is perfectly beautiful when in bloom. It is equally ornamental when loaded with its crimson fruits.

Each Per 10

4 to 5 ft..............\$2.50 \$20.00

5 to $6 \mathrm{ft} \ldots \ldots \ldots \ldots \ldots \ldots \ldots 3.50 \quad 30.00$

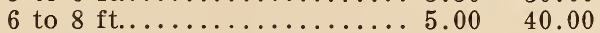

Specimens 8 to $10 \mathrm{ft}$., B. \& B..... 10.00

\section{Cordata-Washington Thorn.}

A very desirable dwarf tree with beautiful large clusters of bright red fruit remaining a long time on the branches.

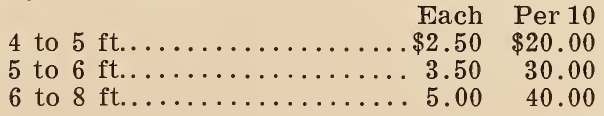

\section{Crus Galli-Cockspur Thorn.}

This tree gets its name from its lone, spurlike thorns. It is easily one of the most beautiful of all hawthorns, either in flower or fruit. It might be interesting to know the Hawthorne has been selected as the Missouri State Flower.

Each Per 10

3 to $4 \mathrm{ft} . \ldots \ldots \ldots \ldots \ldots \ldots . \ldots 2.00 \quad \$ 17.50$
C. Mollis-Scarlet Fruited Thorn.

The lovely blossoms of this beautiful tree are of a bright, scarlet color, large, very full. Each Per 10

5 to $6 \mathrm{ft} . \ldots \ldots \ldots \ldots \ldots \ldots \ldots 3.50 \$ \$ 30.00$

6 to $8 \mathrm{ft} . \ldots \ldots \ldots \ldots \ldots \ldots . \ldots . \ldots \ldots$

C. Oxycanttha-English Hawthorne.

This variety grows more spreading than some of the varieties.
5 to $6 \mathrm{ft}$
Each Per 10

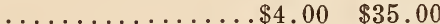
6 to $8 \mathrm{ft} . \ldots \ldots \ldots \ldots \ldots \ldots .50 \ldots$

C. Paul's Scarlet.

The lovely blossoms of this variety are a bright double scarlet.
5 to $6 \mathrm{ft}$
$\$ 5.00$
6 to $7 \mathrm{ft} . \ldots \ldots \ldots \ldots \ldots \ldots 6.60 \ldots \ldots$
$\$ 40.00$ 50.00

FRAXINUS Americana. Syn. alba-

American White Ash.

This becomes a beautiful tree when matured -is of large size and very shapely. Foliage is of dark green, lustrous above, whitened beneath. In autumn, it changes to the most gorgeous of purple and yellow tones. Very desirable for general planting, because of its rapid growth, long life and fine form.

Each Per 10 Per 100

8 to $10 \mathrm{ft} . \ldots \ldots \ldots . \$ 2.00 \quad \$ 17.50 \quad \$ 150.00$

$11 / 4$ to $1 \frac{1 / 2}{2}$ in. Clpr...2 2.50 $22.50 \quad 200.00$

$11 / 2$ to $13 / 4$ in. Clpr... $3.00 \quad 25.00 \quad 225.00$

$13 / 4$ to 2 in. Clpr.... $3.50 \quad 30.00 \quad 250.00$

2 to $2 \frac{1}{2}$ in. Clpr.... $4.00 \quad 35.00 \quad 300.00$

$21 / 2$ to 3 in. Clpr.... $5.50 \quad 45.00 \quad \ldots .$. 


\section{J. Sieboldi-Japan Walnut.}

These are large, spreading trees, with large compound leaves, producing nuts in clusters. The nuts are longer than those of the Persian (English) Walnut and rougher. The shell is almost as thick as that of the Black Walnut; kernel rich and of fine flavor.

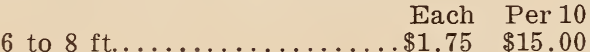

$11 / 4$ to $1 \frac{1}{2}$ in. Clpr..........2.25 20.00

2 to $2 \frac{1}{2}$ in. Clpr............ $3.50 \quad 30.00$

KOELREUTERIA Paniculata-Varnish Tree.

This tree, also known as the Golden Rain Tree, originated in China. It is a very desirable lawn tree, with large pinnate leaves. Produces a mass of showy orange-yellow flowers in July, which are followed by curious seed vessels.

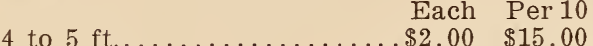

5 to $6 \mathrm{ft} \ldots \ldots \ldots \ldots \ldots \ldots 2.50 \quad 20.00$

\section{LABURNUM Vulgare-Golden Chain.}

This is an ornamental small tree, with showing yellow flowers. Excellent for planting among shrubs in shrubbery borders.

Each Per 10

3 to $4 \mathrm{ft} \ldots \ldots \ldots \ldots \ldots \ldots \ldots 1.25 \$ \$ 10.00$

4 to $5 \mathrm{ft} \ldots \ldots \ldots \ldots \ldots \ldots \ldots \ldots$

\section{LARIX Europea-European Larch.}

An elegant, rapid and pyramidal growing tree, with light green foliage; valuable as a lawn tree. Prefers moist situations.

Specimens from ........ $\$ 15.00$ to $\$ 25.00$

\section{LIQUIDAMBAR Styraciflua-Sweet Gum.}

This tree is beautiful at all stages and useful in all sorts of plantings. Has a narrow and ovate head, formed of short, corky-winged branches and masses of star-shaped, lustrous leaves that color to intense crimson-scarlet in

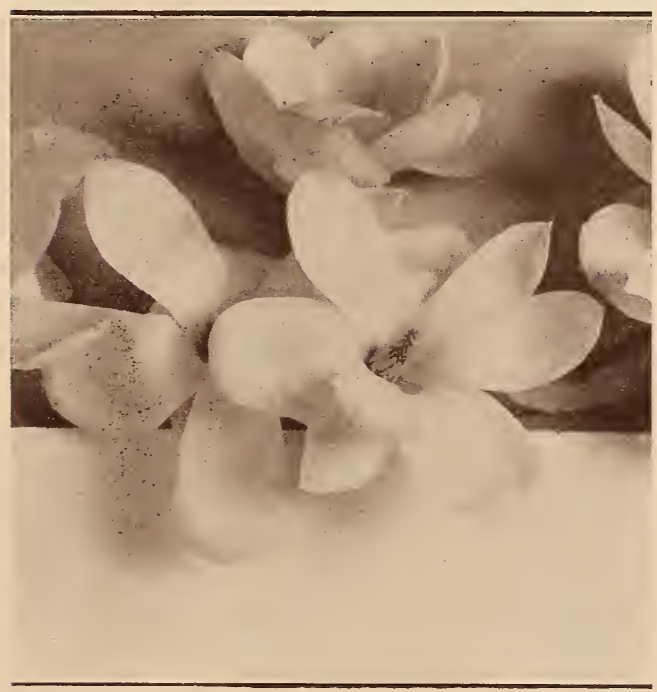

Sweet Magnolia

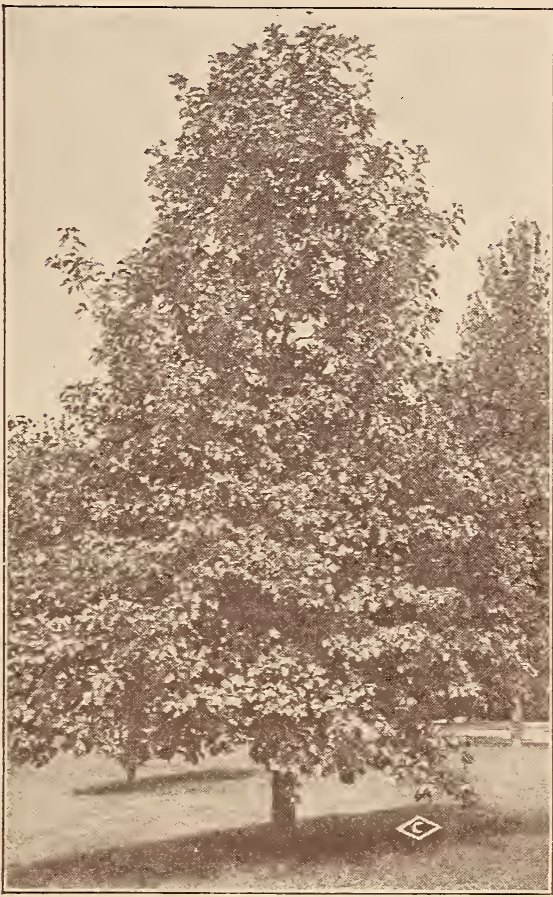

Tulip Tree

the Fall. It gets its name from its fragrant sap and leaves.

Each Per 10

4 to $5 \mathrm{ft}$. with ball........\$4.50 $\$ 40.00$

5 to $6 \mathrm{ft}$. with ball .......6. $6.00 \quad 50.00$

6 to $8 \mathrm{ft}$. with ball.......... $7.50 \quad 70.00$

Specimens B. \& B.......\$15.00 to $\$ 25.00$

\section{LIRIODENDRON Tulipifera-Tulip Tree.}

This is a tall, magnificent native tree, which reaches a rapid growth of 100 feet. Has a smooth, erect gray trunk and is clothed with a splendid vesture of large glossy leaves. In summer, it is spangled with large tulip shaped flowers of greenish yellow and orange. This is one of our most distinguished trees for broad avenues, parks and lawns.

Each Per 10

6 to $8 \mathrm{ft} . \ldots \ldots \ldots \ldots \ldots \ldots \ldots 2.50 \ldots \ldots \ldots \ldots$

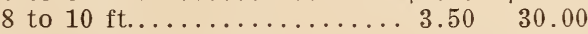

$11 / 4$ to $11 / 2$ in. Clpr....... $4.00 \quad 35.00$

\section{MAGNOLIA Glauca-Sweet Magnolia.}

A beautiful small shrubby tree, thriving in any good soil or situation and useful for yositions too damp for many trees. Has rich glossy green foliage which is silvery beneath. The creamy white wax-like flowers are highly fragrant and the seed pods which follow open to show brilliant coral seeds.

Each Per 10

4 to $5 \mathrm{ft}$. with ball.........\$8.00 $\$ 70.00$

5 to $6 \mathrm{ft}$. with ball........ $10.00 \quad 90.00$

6 to $8 \mathrm{ft}$. with ball.......\$15.00 to $\$ 25.00$ 


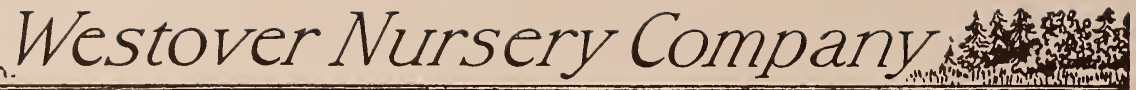

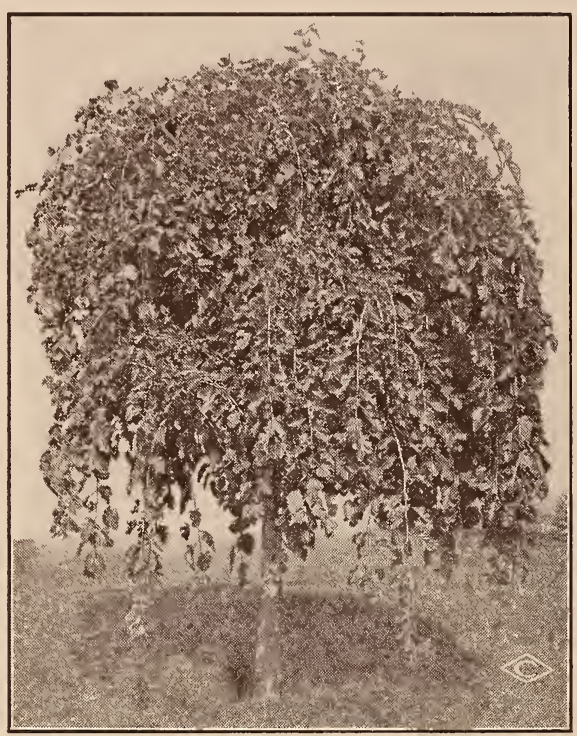

Tea's Weeping Mulberry

MORUS Tartarica-Russian Mulberry.

A very hardy low growing, bushy topped tree with variety of reddish fruit.

Each Per 10

4 to $6 \mathrm{ft} . \ldots \ldots \ldots \ldots \ldots \ldots \ldots \ldots 1.50 \quad \$ 12.50$

6 to $8 \mathrm{ft} \ldots \ldots \ldots \ldots \ldots \ldots \ldots \ldots 2.00 \quad 15.00$

M. Tartarica Pendula-Tea's Weeping Mulberry.

This is one of the best of the small weeping lawn trees. It forms a perfect umbrella shaped head. Foliage light green, deeply lobed. Fruit reddish purple. Thrifty and hardy.

2-year heads, each...........\$4.25

Specimens, $3 \& 4$-yr. heads, each.$\$ 5$ to $\$ 7.50$

PLATANUS Occidentalis-Buttonwood or American Sycamore.

Each Per 10 Per 100

8 to $10 \mathrm{ft} . \ldots \ldots \ldots . \$ 2.75 \$ 25.00 \quad \$ 200.00$

$1 \frac{1 / 4}{4}$ to $1 \frac{1 / 2}{2}$ in. Clpr... $3.50 \quad 32.50 \quad 250.00$

$11 / 2$ to $13 / 4$ in. Clpr... $4.00 \quad 35.00 \quad 300.00$

$13 / 4$ to 2 in. Clpr.... $5.50 \quad 50.00 \quad 450.00$

2 to $2 \frac{1}{2}$ in. Clpr.... $6.50 \quad 60.00 \quad 500.00$

$21 / 2$ to 3 in. Clpr..... $7.50 \quad 65.00 \quad 600.00$

\section{P. Orientalis-Oriental Plane or European} Sycamore.

This tree ranks as one of the best for street and avenue planting. It grows to a grand size, is bold, picturesque, healthy, free from insects, vigorous in all soils, especially at the water's edge. Grows from 60 to 80 feet tall.

Each Per 10 Per 100

8 to $10 \mathrm{ft} \ldots . . . \$ 2.75 \$ 25.00 \quad \$ 200.00$

$1 \frac{1 / 4}{4}$ to $1 \frac{1 / 2}{2}$ in. Clpr... $3.50 \quad 32.50 \quad 250.00$

$1 \frac{1 / 2}{2}$ to $13 / 4$ in. Clpr... $4.00 \quad 35.00 \quad 300.00$

$13 / 4$ to 2 in. Clpr.... $5.50 \quad 50.00 \quad 450.00$

2 to $2 \frac{1}{2}$ in. Clpr.... $6.50 \quad 60.00 \quad 500.00$

$21 / 2$ to 3 in. Clpr.... $7.50 \quad 65.00 \quad 600.00$

3 to $3 \frac{1}{2}$ in. Clpr.... $8.50 \quad 80.00 \quad \ldots .$.
POPULUS Alba Bolleana-Bolles Silver Poplar.

This tree is similar to the well-known Lombardy Poplar in habit, but broader. Well liked because of its ability to break the monotony of lower, round topped trees. Will grow to a tall spire, 80 feet high. Leaves are a glossy green above, silvery beneath. A farorite with landscape gardeners.

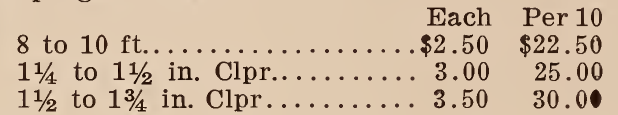

\section{P. Alba-Silver Spreading Poplar.}

Similar to Bolleana Poplar excepting that it grows into a spreading tree.

Each Per 10

$11 / 2$ to $13 / 4$ in. Clpr......... \$2.50 $\$ 20.00$

2 to $2 \frac{1}{2}$ in. Clpr........... $3.50 \quad 30.00$

\section{P. Monilifera-Carolina Poplar.}

This tree is a horticultural cottonwood, pyramidal in form and vigorous in growth. Leaves are large, glossy pale to deep green. Valuable for street planting on account of their extremely rapid growth.

\begin{tabular}{|c|c|c|}
\hline Each & Per 10 & Per 100 \\
\hline $3 / 4$ in. Clpr... $\$ 1.50$ & $\$ 12.50$ & $\$ 100.00$ \\
\hline in. Clpr. & 17.50 & 160.00 \\
\hline in. Clpr. & 20.00 & 175.00 \\
\hline n. Clpr. & 30.00 & \\
\hline a. Clpr. & 40.00 & \\
\hline n. Clpr.. & 50.00 & \\
\hline
\end{tabular}

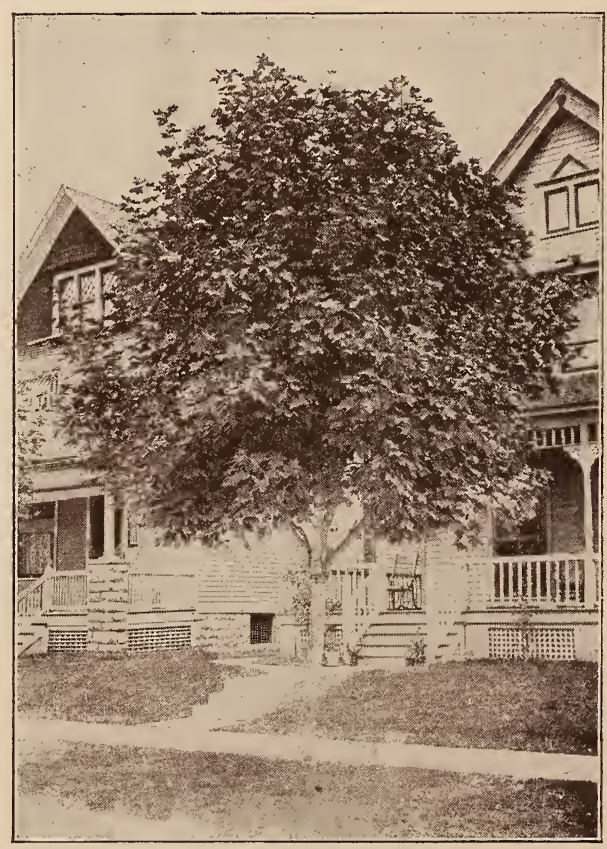

Sycamore 


\section{P. Nigra Fastigiata-Lombardy Poplar.}

The Lombardy Poplar is a well known and old horticultural variety. Grows narrow and upright, with light green, small leaves. Grows rapidly, often reaching 100 to 150 feet. Also very popular in landscape gardening, inasmuch as it breaks the ordinary and monotonous outline of other trees.

\begin{tabular}{|c|c|c|}
\hline & Each & Per 10 \\
\hline 8 to $10 \mathrm{ft} . \ldots . .$. &.$\$ 1.00$ & $\$ 9.00$ \\
\hline $13 / 4$ in. Clp & 2 & 20.00 \\
\hline 2 in. Clpr. & 3.00 & 25.00 \\
\hline n. $\mathrm{Clp}$ & 4.00 & 35.00 \\
\hline in. $\mathrm{Clp}$ & 5.00 & 40.00 \\
\hline
\end{tabular}

\section{P. Simoni-Simon's Poplar.}

This tree grows pyramidal like the Lombardy Poplar, the leaves however being rounded at the base similar to the leaves of a pear tree.

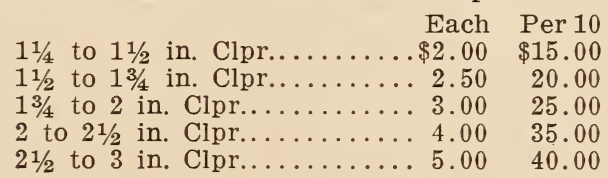

\section{PRUNUS Persica Rubra and Alba-Double}

Red or White Flowering Peach.

Pretty in formal garden or among shrubbery, as it has an abundance of double red or white flowers before the leaves come out in spring.

Each Per 10

3 to $4 \mathrm{ft} . \ldots \ldots \ldots \ldots \ldots \ldots \ldots 1.00 \$ 9.00$

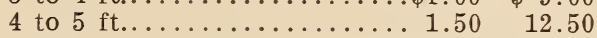

Specimens ......\$3.50 to $\$ 5.00$ Each

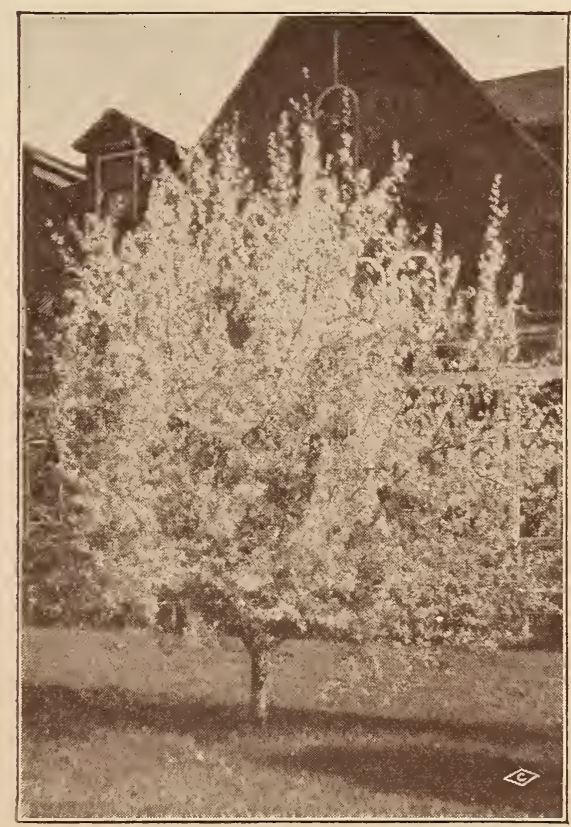

Double Flowering Peach

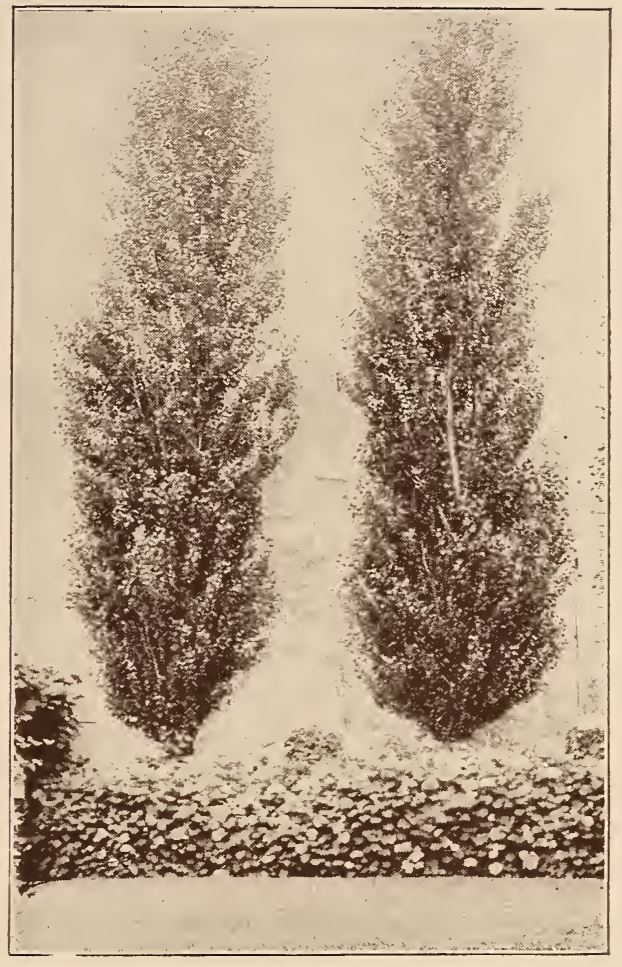

Lombardy Poplar

\section{P. Pissardi-Purple Leaf Plum.}

A charming shrub or small tree, with purplish red leaves, growing about $\&$ to 15 feet high, of spreading, vigorous growth. Very early in the spring, before the leaves appear, the whole tree is decked out in a fleecy cloud of light pink blossoms. Its effect on a still, leafless landscape is very bright.

Each Per 10

4 to $5 \mathrm{ft} \ldots \ldots \ldots \ldots \ldots \ldots \ldots . \$ 1.75 \$ \$ 15.00$

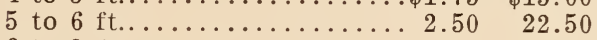

6 to $8 \mathrm{ft} . \ldots \ldots \ldots \ldots \ldots \ldots \ldots . \ldots \ldots$

\section{P. Virginiana-Choke Cherry.}

Bush or small tree not over 30 feet. Bark rough and speckled. Flowers in spring when leaves appear in short, dense racemes.

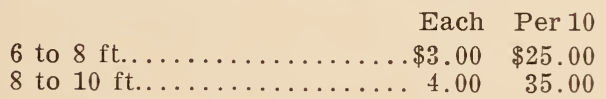

\section{P. Serotina-Wild Black Cherry.}

Its flower racemes are white and fragrant. Leaves are a beautiful glossy black and the fruit is black.

Each Per 10

4 to $5 \mathrm{ft} . \ldots \ldots \ldots \ldots \ldots \ldots \ldots . . \ldots 1.25 \$ \$ 10.00$

2 to $2 \frac{1}{2}$ in. Clpr......... $4.00 \quad 35.00$ 


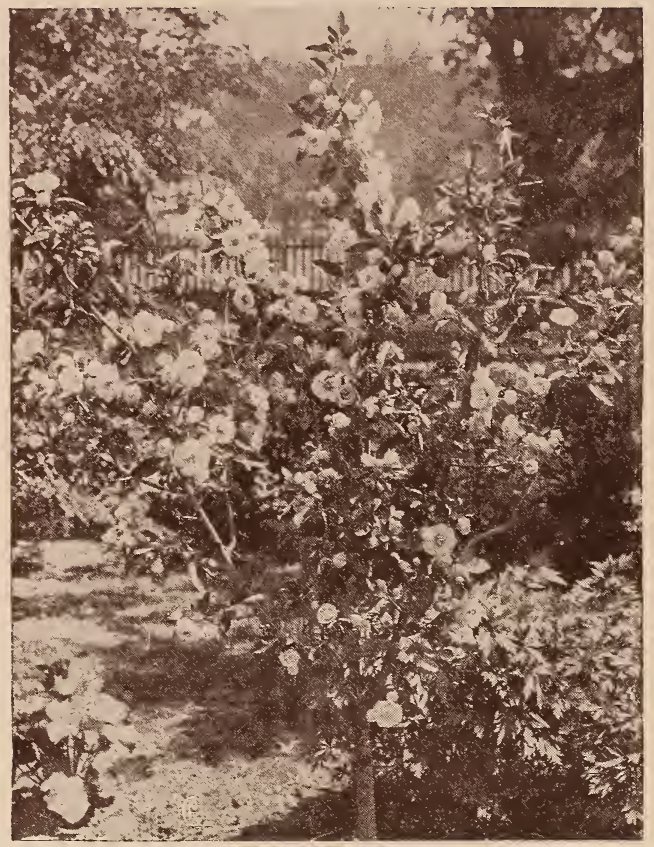

Bechtel's Flowering Crabs

\section{P. Triloba-Flowering Plum.}

A very desirable and beautiful flowering shrub coming from China. It resembles the flowering almond blossoms, also in the manner in which it blooms. Early in the spring, before its leaves appear, its delicate pink petals begin to unfold and when fully open, resembles a miniature rose.

Each Per 10

3 to $4 \mathrm{ft} . \ldots \ldots \ldots \ldots \ldots \ldots \ldots 1.50 \quad \$ 12.50$

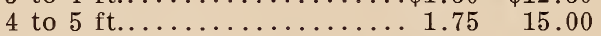

PYRUS Syn. Malus Ioensis Bechteli-

Bechtel's Double Flowering Crab.

This tree seldom reaches a height of over 20 feet. Blooms in late spring with myriads of delicate pink flowers, resembling the daintiest of double roses. Blooms when quite young.

Each Per 10

3 to $4 \mathrm{ft} \ldots \ldots \ldots \ldots 2.00 \quad \$ 15.00$

4 to $5 \mathrm{ft} \ldots \ldots \ldots \ldots \ldots \ldots \ldots \ldots 2.50 \quad 22.50$

5 to $6 \mathrm{ft} . \ldots \ldots \ldots \ldots \ldots \ldots . \ldots \ldots$

P. Syn. Malus Coronaria-Wild Crab.

Has fragrant single blush blossoms.

Each Per 10

3 to 4 ft..............\$1.50 $\$ 12.50$

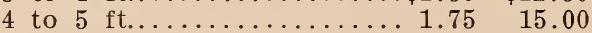

5 to $6 \mathrm{ft} . \ldots \ldots \ldots \ldots \ldots \ldots 2.25 \quad 20.00$

P. Syn. Malus Floribunda AstrosangueineaSingle Pink.

One of the best small trees, of profuse flowering habit. Bright pink buds, followed by almost white flowers, smother the tree before leaves form. Red fruit about the size of a pea. Entirely hardy.

Each Per 10

4 to $5 \mathrm{ft} . \ldots \ldots \ldots \ldots \ldots \ldots \ldots 2.00 \$ 15.00$

5 to $6 \mathrm{ft} \ldots \ldots \ldots \ldots \ldots \ldots \ldots \ldots 2.50 \quad 20.00$

5 to 6 ft...
P. Syn. Malus Niedzwetzkyana-Single Pink. This variety has reddish foliage and pink flowers. Very attractive when in bloom.
Each Per 10
4 to $5 \mathrm{ft} . \ldots \ldots \ldots \ldots \ldots \ldots \ldots 2.00 \quad \$ 15.00$

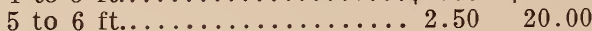

\section{P. Zumeii-Japanese Flowering Crab.}

A new variety of flowering crap apple, having beautiful single pink blossoms.

6 to $8 \mathrm{ft} \ldots \ldots \ldots \ldots \ldots \ldots \$ 4.00 \quad \begin{aligned} & \text { Each } 10 \\ & \$ 35.00\end{aligned}$

\section{P. Toringi-Japanese Flowering Crab.}

Same as above.

Each Per 10

6 to $8 \mathrm{ft} . \ldots \ldots \ldots \ldots \ldots . \$ 4.00 \quad \$ 35.00$

\section{QUEREUS Palustris-Pin Oak.}

This is a tall tree, with spreading branches of graceful lines. In common with the other oaks, is of rather slow growth at first, but if given good soil and room, develops into a splendid specimen. Leaves are smooth, of bright green, and turn to purplish color in autumn.

Each Per 10

8 to $10 \mathrm{ft} . \ldots \ldots \ldots \ldots \ldots \ldots . . \ldots 30 \quad \$ 32.50$

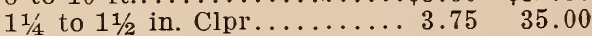

$11 / 2$ to $13 / 4$ in. Clpr......... $4.50 \quad 42.50$

$13 / 4$ to 2 in. Clpr..........6. $6.00 \quad 50.00$

2 to $2 \frac{1 / 2}{1}$. Clpr........... $7.50 \quad 70.00$

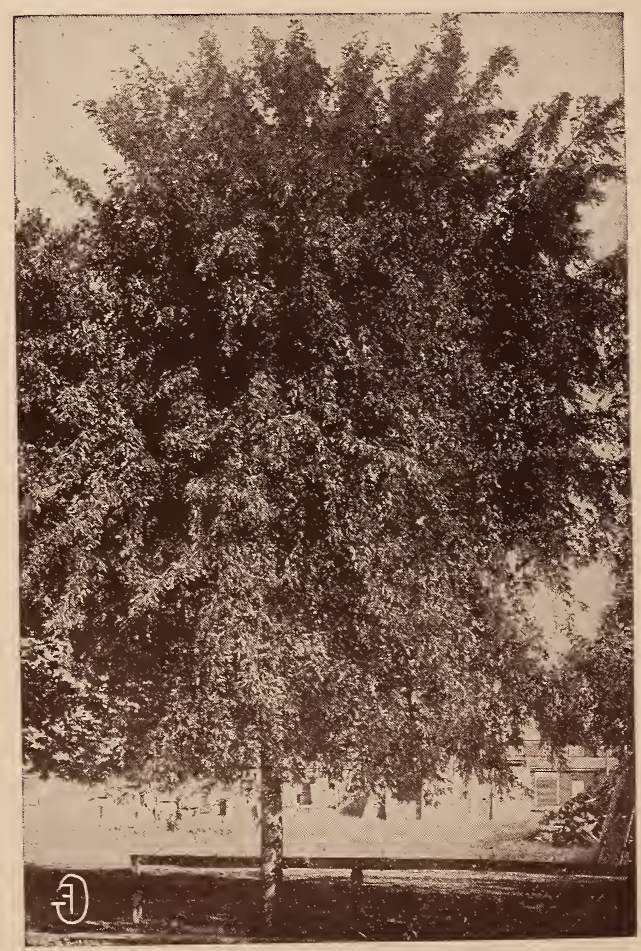

Pin Oak 


\section{Q. Robur-English Oak, Spreading.}

The royal oak of England, a well known tree, of spreading slow growth.

Specimens, B. \& B....... $\$ 25.00$ to $\$ 50.00$

\section{Q. Robur var. Fastigiata-Pyramidal English Oak}

Specimens, B. \& B......\$25.00 to $\$ 50.00$

\section{ROBINIA Hispida-Rose Acacia.}

Is valued for its elegant rose-colored flowers, in long, wisteria-like racemes, which expand towards the close of May.

Each Per 10

2 to $3 \mathrm{ft} . \ldots \ldots \ldots \ldots \ldots \ldots \ldots . . \ldots 0 \ldots . \ldots . . \ldots 0$

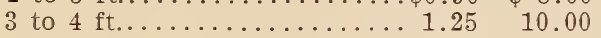

4 to $5 \mathrm{ft} \ldots \ldots \ldots \ldots \ldots \ldots \ldots$
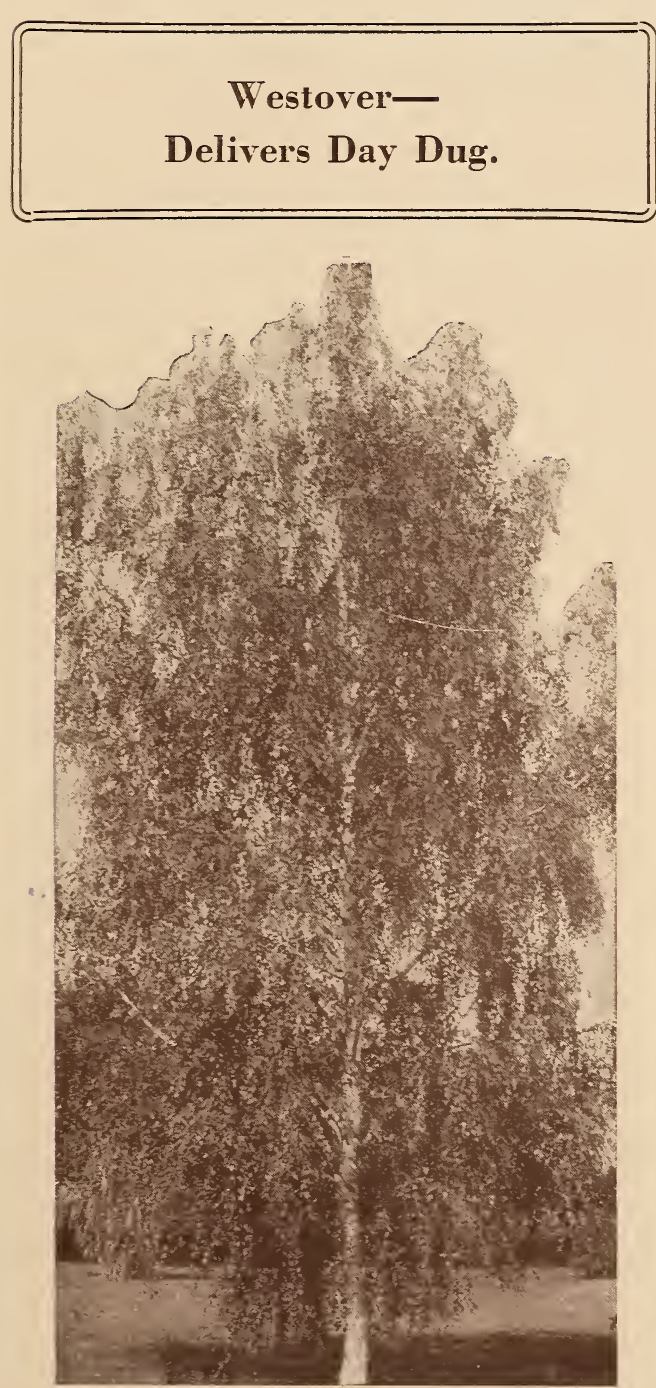

Cut Leaved Weeping Birch

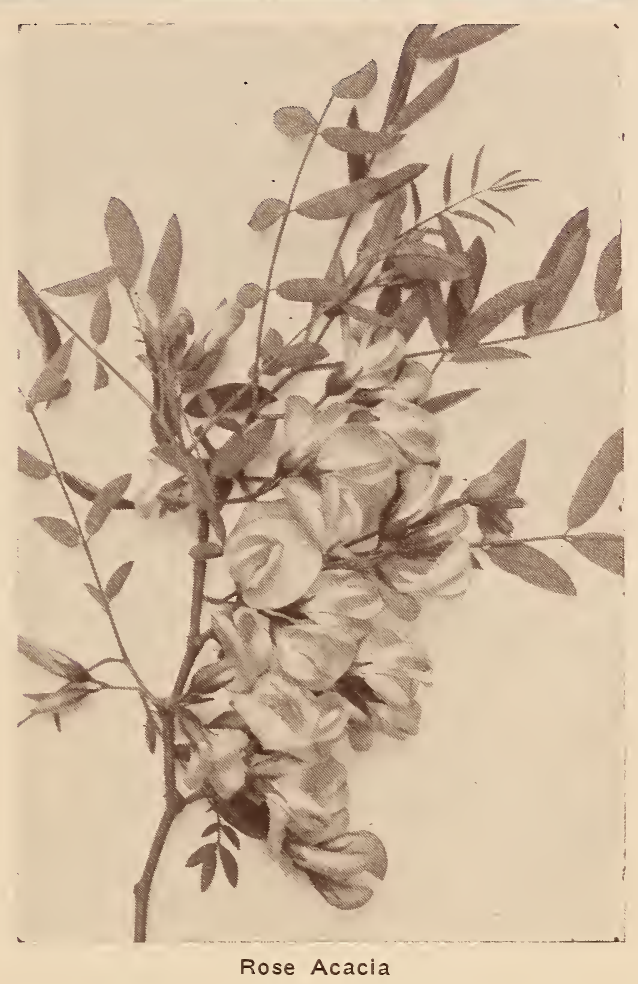

R. Pseudocacia-Black Locust.

A familiar tree of rapid growth, that thrives in any place. The pinnate foliage is light and airy. In June, the tree is fragrant with pannicles of white flowers and very ornamental. Valuable for planting where quick results are wanted.

Each Per 10

8 to $10 \mathrm{ft} . \ldots \ldots \ldots \ldots \ldots \ldots \ldots 2.25 \$ \$ 20.00$

$11 / 4$ to $1 \frac{1 / 2}{}$ in. Clpr.......... $2.75 \quad 25.00$

$1 \frac{1 / 2}{}$ to $13 / 4$ in. Clpr......... 3.2530 .00

$13 / 4$ to 2 in. Clpr.......... $3.50 \quad 32.50$

\section{SALIX Babylonica-Weeping Willow.}

This is probably the best known of the Willows; weeping habit, with long, slender, olive green branches. Often grown in cemeteries. Height, 40 feet.

Each Per 10

6 to $8 \mathrm{ft} \ldots \ldots \ldots \ldots \ldots \ldots \ldots 1.50 \quad \$ 12.50$

8 to $10 \mathrm{ft} . \ldots \ldots \ldots \ldots \ldots \ldots \ldots$

\section{S. Caprea-Pussy Willow.}

Branches spreading and drooping, forming an umbrella shaped head. Very useful for early effects, around edges of marshy ground or grouped anywhere.

Each Per 10

4 to $5 \mathrm{ft} . \ldots \ldots \ldots \ldots \ldots \ldots 1.25 \$ \$ 10.00$ 


\section{Westover Nursery Company}

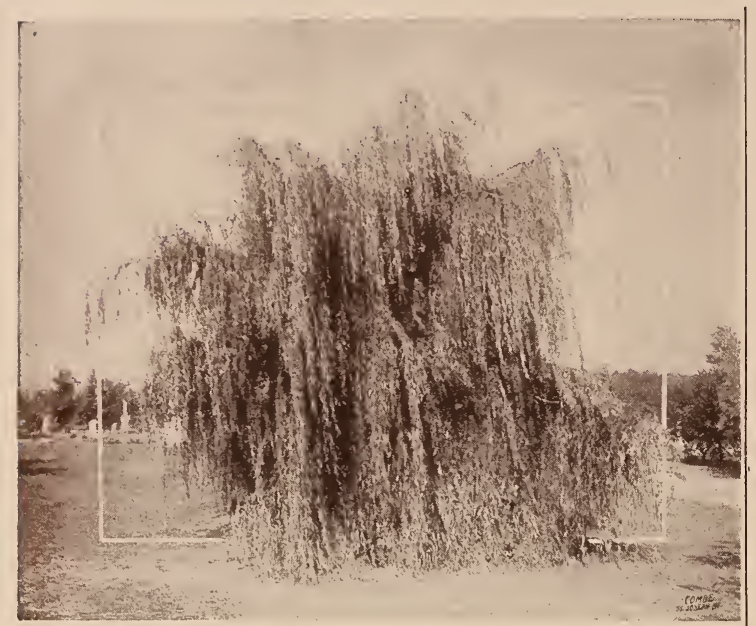

Thurlow's Weeping Willow

\section{S. Dolorosa-Wisconsin Weeping Willow.}

Of drooping habit and hardier than Salix Babylonica. Valuable on account of its ability to resist severe cold.

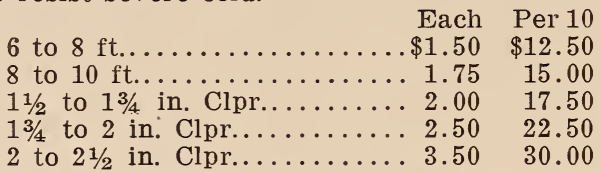

S. Elegantissima-Thurlow's Weeping Willow.

Hardier than Babylonica. Has a large crown with spreading habit.

Each Per 10

8 to $10 \mathrm{ft} . \ldots \ldots \ldots \ldots \ldots \ldots 1.75 \$ 15.00$

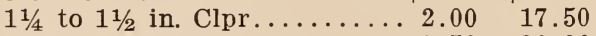

2 to $21 / 2$ in. Clpr.......... $3.50 \quad 30.00$

$2 \frac{1}{2}$ to 3 in. Clpr.......... $4.00 \quad 35.00$

\section{S. Pentranda-Laurel Willow.}

Ornamental tree of upright growth; bark brownish green, leaves dark and glossy green.

Each Per 10

6 to $8 \mathrm{ft} \ldots \ldots \ldots \ldots \ldots \ldots \ldots \ldots 1.75 \$ \ldots 15.00$

8 to $10 \mathrm{ft} \ldots \ldots \ldots \ldots \ldots \ldots \ldots 2.50 \quad 22.50$

\section{S. Rosmarinifolia-Rosemary Willow.}

Dwarf habit, feathery branches, silvery foliage.

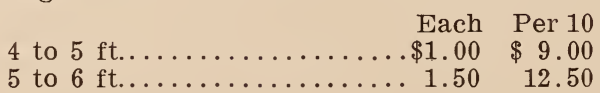

\section{S. Vitellina Aurea-Gold Barked Willow.}

Grows into a massy low-headed tree, light green leaves and brilliant golden-yellow bark in winter. One of the hardiest of willows.

Each Per 10

$11 / 4$ to $11 / 2$ in. Clpr........\$1.75 $\$ 15.00$

$11 \frac{2}{2}$ to $13 / 4$ in. Clpr.................. $2.00 \quad 17.50$

Specimens, each.......\$5.00 to $\$ 15.00$

\section{S. Sp.-Bush Form.}

Shrub or low bushy tree growing to about 15 feet.

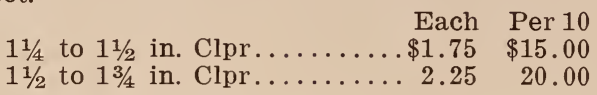

\section{SASSAFRAS Officinale-}

An aromatic tree with spreading branches, forming a flat topped head. Flowers yellowgreen. Dark blue fruits ripen in autumn. The roots are highly esteemed as aromatic stimulant. 20 to 25 feet.

$1 \frac{1}{2}$ to $1 \frac{3}{4}$ in. Clpr........ Each $\begin{array}{r}\text { Per } 10 \\ \$ 4.50\end{array}$

\section{SORBUS-Aucuparia-Mountain Ash.}

Medium sized tree, with handsome, pinnate leaves, neat habit and showy crops of bright, red berries. Persistent until the late winter, giving a brilliant note to the autumn landscape.

Each Per 10

5 to $6 \mathrm{ft} . \ldots \ldots \ldots \ldots \ldots \ldots \ldots 2.00 \quad \$ 15.00$

6 to $8 \mathrm{ft} \ldots \ldots \ldots \ldots \ldots \ldots \ldots \ldots 2.50 \quad 22.50$

8 to $10 \mathrm{ft} . \ldots \ldots \ldots \ldots \ldots \ldots . . \ldots 30 \quad 30.00$

\section{TAXODIUM Distichum-Cypress Tree.}

Tall thin shape, soft light green foliage against Cinnamon bark. Prefers moisture.

Each Per 10

6 to $8 \mathrm{ft}$. with ball.........\$7.00 $\$ 60.00$

Specimens, each.......\$25.00 to $\$ 35.00$

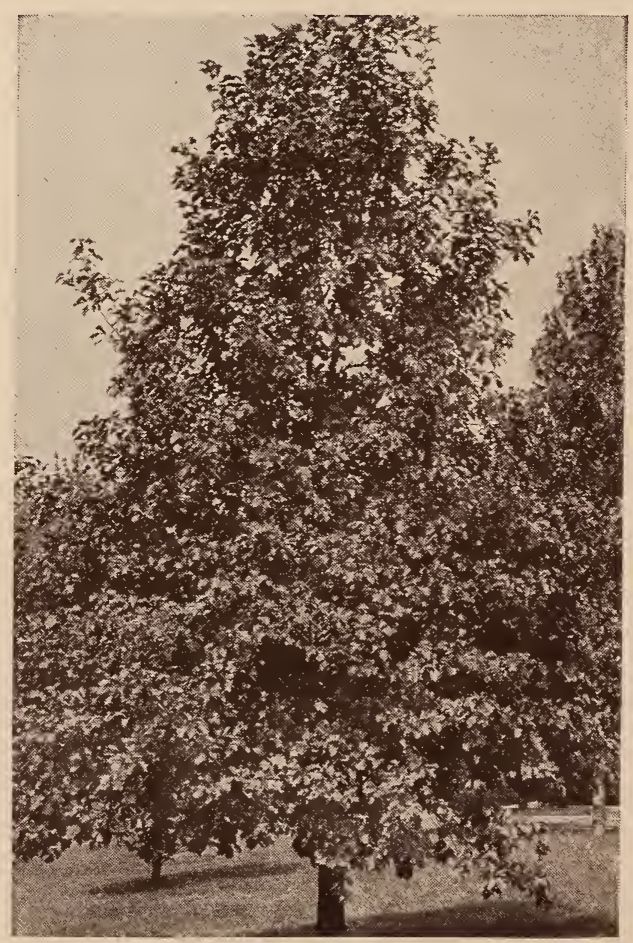

Mountain Ash 


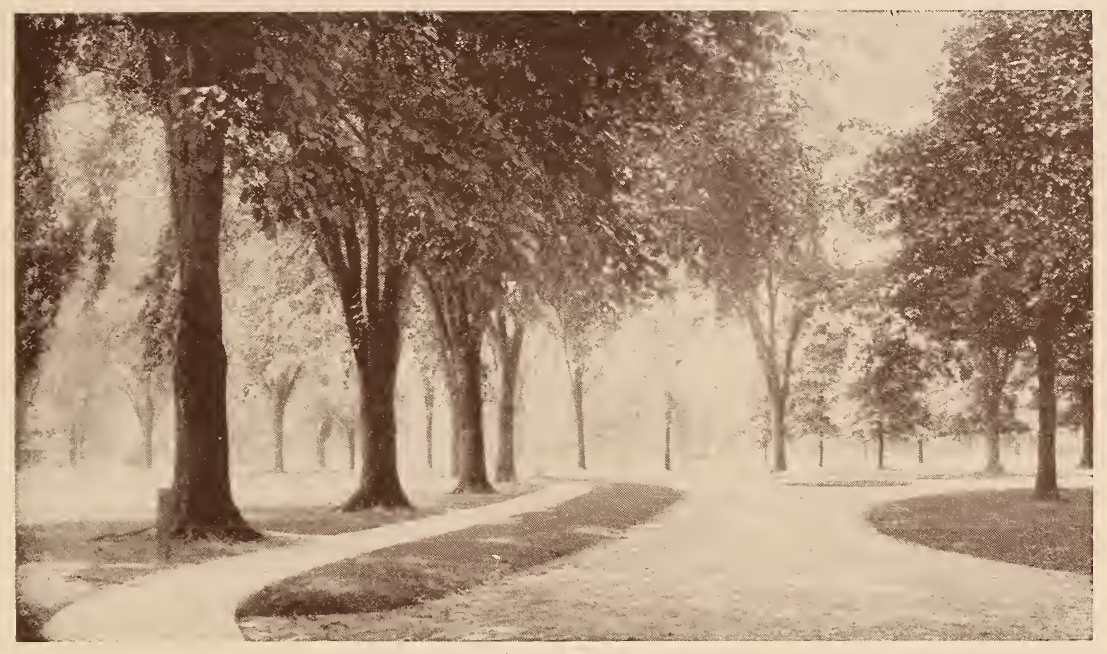

\section{American EIms}

\section{TILIA Americana-American Linden.}

A stately tree, growing to 60 and 80 feet tall, with large, shining cordate leaves. Particularly valuable for its beautiful, white wood. Flowers in July.

Each Per 10

6 to $8 \mathrm{ft} . \ldots \ldots \ldots \ldots \ldots \ldots \ldots 2.50 \quad \$ 20.00$

$1 \frac{1 / 4}{4}$ to $1 \frac{1}{2}$ in. Clpr........4 $4.00 \quad 35.00$

$1 \frac{1 / 2}{2}$ to $1 \frac{3 / 4}{4}$ in. Clpr........ $4.50 \quad 40.00$

$13 / 4$ to 2 in. Clpr......... 5.00 45.00

2 to $2 \frac{1}{2}$ in. Clpr.......... $7.50 \quad 70.00$

\section{T. Platyphylos-Large Leaved.}

An exceedingly, broad-leaved variety, growing into a noble tree of 60 to 80 feet high. It flowers in June, the earliest of the Lindens.

Each Per 10

$21 / 2$ to 3 in. Clpr......... $7.50 \$ 70.00$

3 to $3 \frac{1}{2}$ in. Clpr........ $10.00 \quad 90.00$

$31 / 2$ to 4 in. Clpr......... $12.50 \quad 100.00$

We have a large number of specimens of this tree, prices of which will be sent promptly upon request.

\section{ULMUS Americana-American Elm.}

Easily distinguished by its large, wide-arching top, vase like form and pendulous branchlets. Next to the oak, this is the grandest and most picturesque of American trees. Attains height of 80 to 100 feet. Dull yellow or brown in fall.

Each Per 10

8 to $10 \mathrm{ft} . \ldots \ldots \ldots \ldots \ldots \ldots 2.00$

$11 / 4$ to $11 / 2$ in. Clpr......... 2.75

$1 \frac{1 / 2}{}$ to $13 / 4$ in. Clpr......... 3.25

$13 / 4$ to 2 in. Clpr........... 4.25

2 to $2 \frac{1}{2}$ in. Clpr.......... 5.00

$21 / 2$ to 3 in. Clpr...........6. 6.00

Specimens, each........ $\$ 10.00$ to $\$ 25.00$

\section{U. Racemosa-Cork Barked Elm.}

Short spreading branches, forming an oblong, round topped head. Branchlets irregularly corky-winged after first year.

Sizes and Prices quoted on request.

\section{U. Pumila-Dwarf Elm.}

A graceful hardy tree which grows 40 feet tall and about 40 feet broad. Can also be trim. med pyramidal.

Each Per 10

$1 \frac{1 / 4}{4}$ to $1 \frac{1}{2}$ in. Clpr......... $\$ 4.00 \$ 35.00$

$1 \frac{1}{2}$ to $13 / 4$ in. Clpr.......... $4.50 \quad 40.00$

$13 / 4$ to 2 in. Clpr.......... $5.00 \quad 45.00$

Specimens, each........\$7.50 to $\$ 15.00$

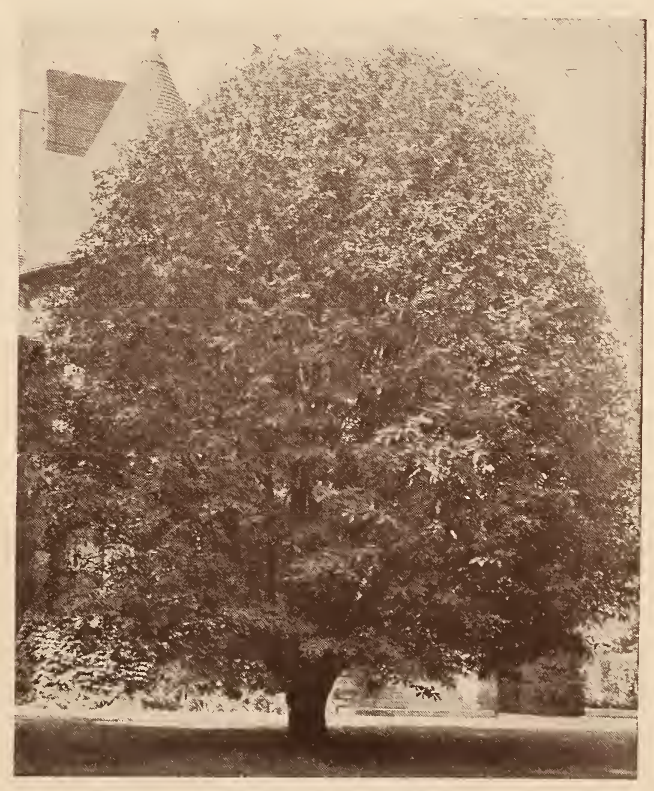

American Linden 


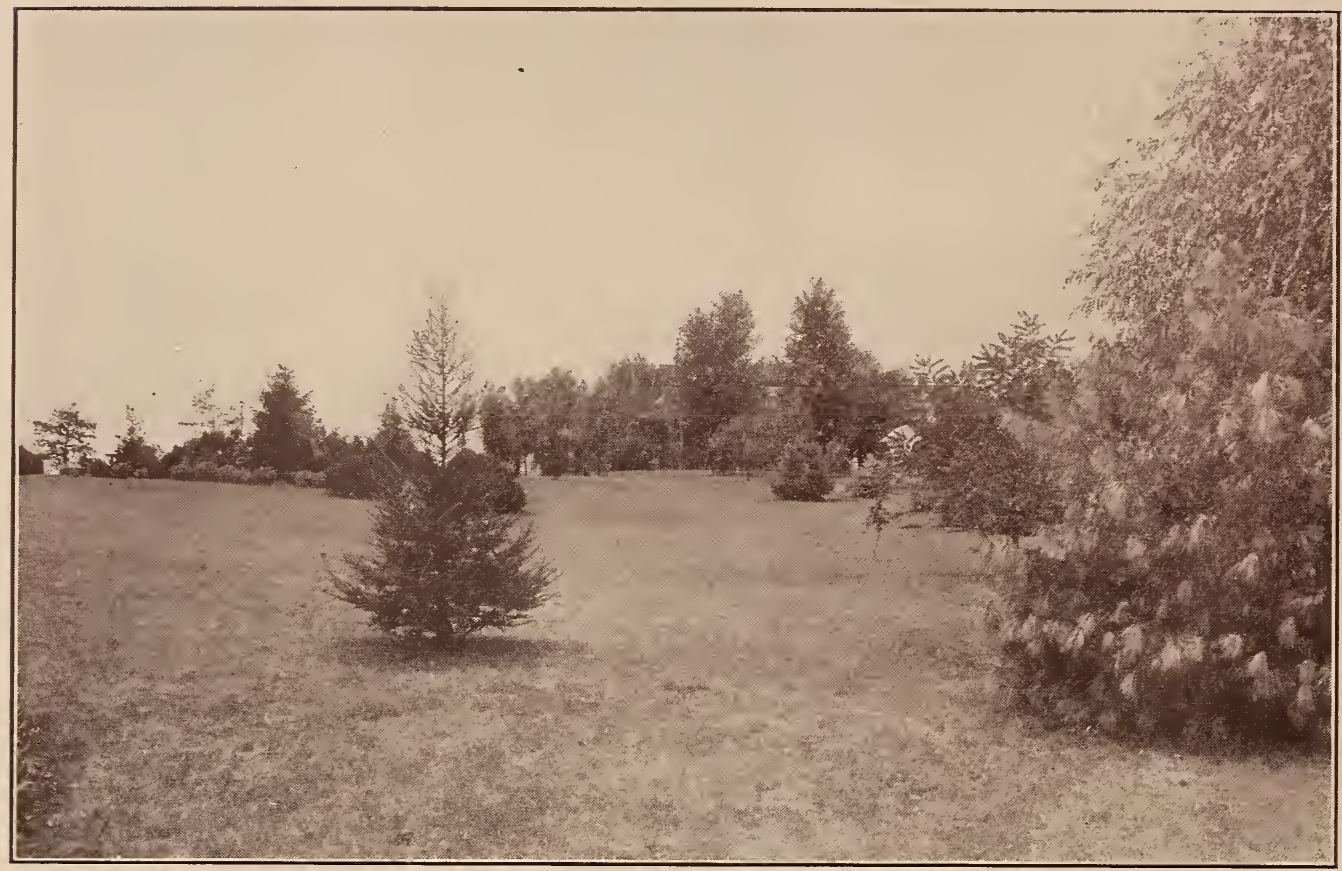

A view of Westover Display Grounds

\section{Evergreen Trees}

W

ITH Evergreens, beautiful groupings can be made. However, care must be exercised in the selection of varieties and one must know the habit of growth and be able to contrast the different foliages so that the real beauty will stand out. Formerly, evergreens were used only for screens or classed as fit for cemeteries. In recent years, though, hundreds of new uses have been found for them. As backgrounds for flowering shrubs, evergreens have proven their real worth and the winter landscape is far from complete without the cheery colors and shades of the evergreen.

Our evergreens are given special care. They are handled carefully and transplanted frequently to remove any possible danger in transferring them from our nursery. Each tree is planted to insure a symmetrical growth and to guarantee its development into a shapely specimen. All are priced balled with earth and wrapped in burlap in order that they may reach you in perfect condition.

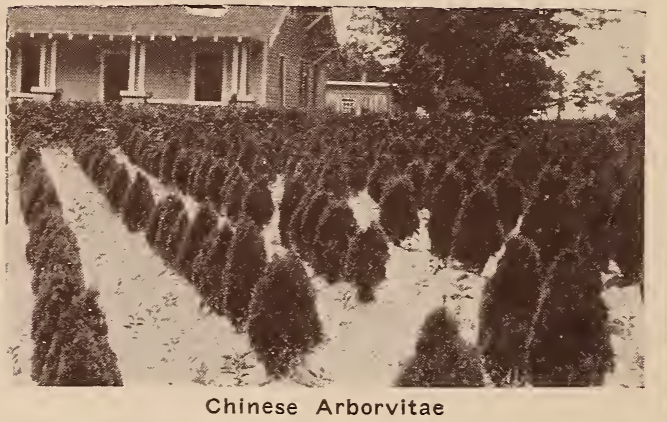

\section{ABIES Concolor-White Fir.}

This is one of the hardiest and most beautiful of the Evergreens. Cones of purple or yellow; silvery green foliage. A rare and exceedingly choice variety.

\section{Each Per 10}

2 to $3 \mathrm{ft} . \ldots \ldots \ldots \ldots \ldots \ldots 6.50 \$ 60.00$

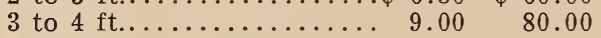

4 to $5 \mathrm{ft} . \ldots \ldots \ldots \ldots \ldots \ldots 12.50 \quad 100.00$

A. Pectinata-Silver Fir.

Medium in size, with horizontal branches and thick massive dark green foliage, similar to Nordman's Fir.

Each Per 10

in .........\$12.50 \$100.00

Specimens, each........ $\$ 15.00$ to $\$ 35.00$ 


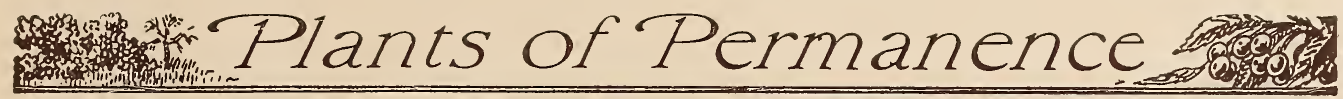

A. Nordmaniana-Norman's Silver Fir.

Medium in size, with horizontal branches and thick, massive, dark green foliage.

Each Per 10

36 to 42 in............\$12.50 $\$ 100.00$

Specimens, each ....... $\$ 15.00$ to $\$ 35.00$

\section{BIOTA Orientalis-Chinese Arborvitae.}

Bushy, upright in growth, fast growing and very attractive. Branches arranged in flat vertical planes. Beautiful deep green color. Foliage very lacy.

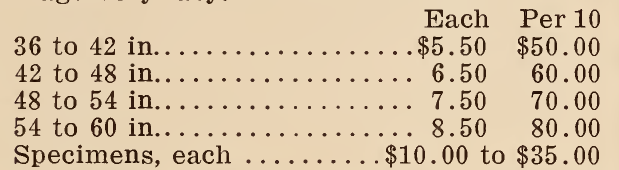

B. Orientalis Globosa-Chinese Globe Form. This variety grows to a globe form without shearing. Rich dark green foliage.

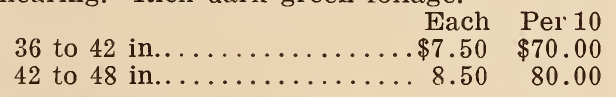

\section{B. Orientalis Compacta.}

Similar to Chinese Arborvitae except that the plants are selected compact form.

\begin{tabular}{|c|c|}
\hline Each & Per 10 \\
\hline 36 to 42 in.. & $\$ 60.00$ \\
\hline . 7.50 & 70.00 \\
\hline 48 to 54 in... . & 80.00 \\
\hline
\end{tabular}

\section{B. Aurea Conspicua.}

A fine pyramidal, bright golden form. Popular because of its grace.

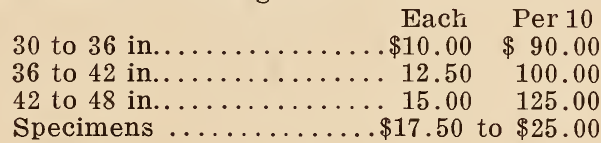

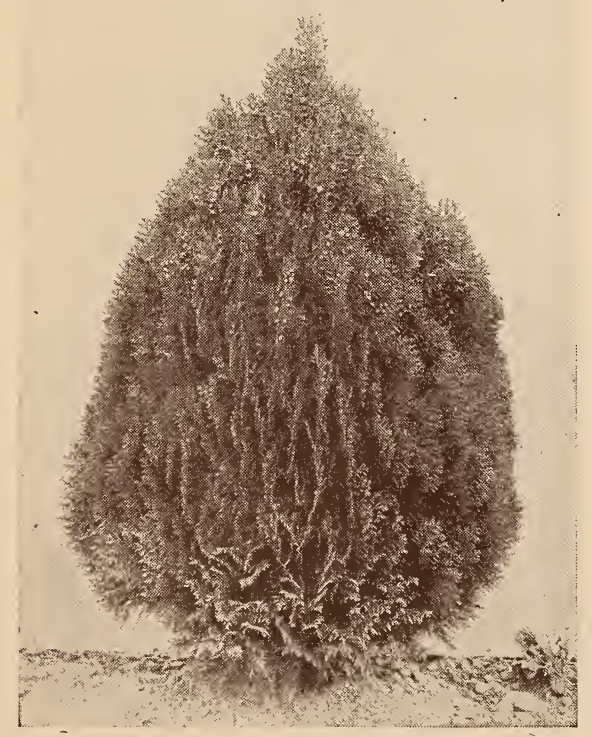

Berkman's Golden Arborvitae

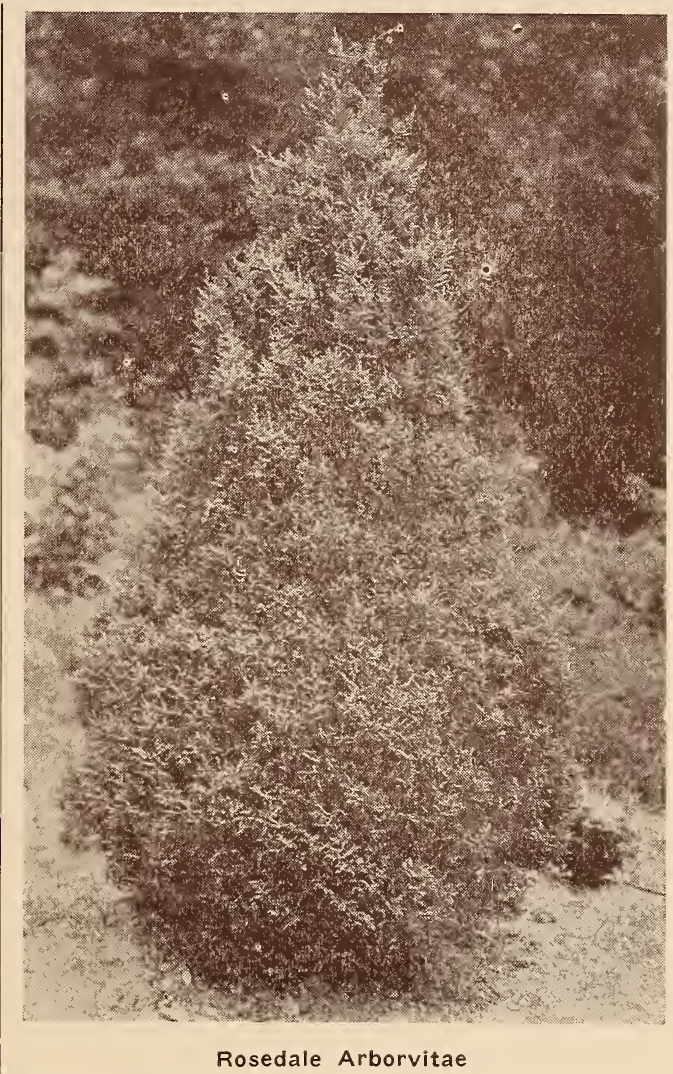

B. Aurea Nana-Berkman's Golden Arborvitae.

The most popular Biota grown. It is of dwarf compact and symmetrical habit. Most suitable for small gardens, cemetery lots, formal plantings, or to add color in Evergreen groups.

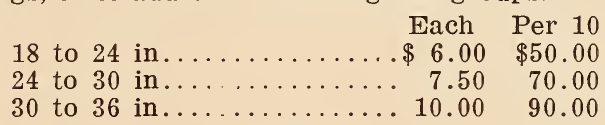

\section{B. Bonita-Globe Form.}

This is a dwarf globe shape growing form of Chinese Arborvitae with dark green foliage.

Each Per 10

24 to 30 in.............\$7.50 $\$ 70.00$

30 to 36 in............... $8.50 \quad 80.00$

\section{B. Rosedale Hybrid.}

This is a globe form Arborvitae which has foliage resembling the Retinospora.

\begin{tabular}{|c|c|}
\hline Each & Per 10 \\
\hline$\ldots \$ 5.00$ & $\$ 45.00$ \\
\hline
\end{tabular}

\section{CUPRESSUS Lawsoniana-Triumph of} Boskoop.

Each Per 10

48 to 54 in.............\$15.00 $\$ 125.00$

Specimens ..........\$17.50 to $\$ 25.00$ 


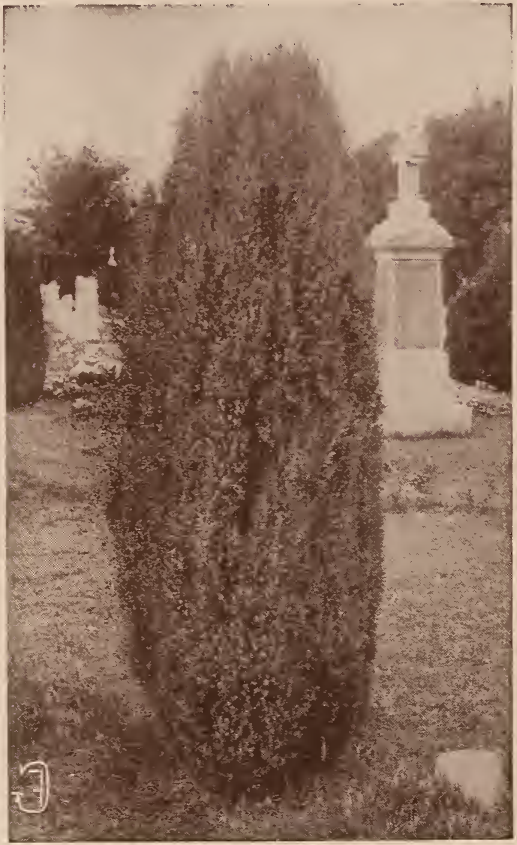

Irish Juniper

JUNIPERUS Communis Hibernica-Irish Juniper.

A distinct and beautiful variety, of erect dense, conical outline, resembling a pillar of green. A very desirable plant.

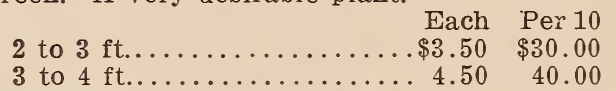

\section{J. Chinenis-Chinese Juniper.}

A very handsome, upright, densely foliaged cedar type. The color is a bright green at all seasons. One of the best green upright growing Junipers.

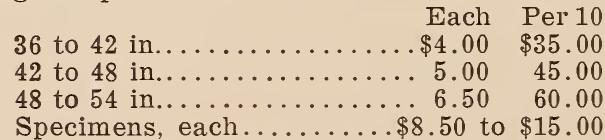

\section{J. Procumbens-Spreading Juniper.}

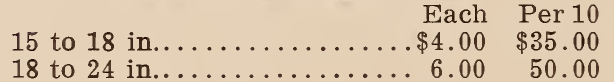

\section{J. Communis Depressa-Prostrate Juniper.}

This is a low spreading Juniper with greyish green foliage. Excellen for foundation planting or massing in front of tall evergreens. Each Per 10

30 to 36 in. spread........\$7.50 \$70.00 36 to 42 in. spread.........9.00 80.00 Specimens, each.......\$10.00 to $\$ 25.00$

\section{J. Communis Suecica-Swedish Juniper.}

A small sized, handsome pyramidal tree, with greyish green foliage. It is very hardy.

Each Per 10

24 to 30 in.............. \$4.00 $\$ 35.00$

30 to 36 in............6. $6.00 \quad 50.00$

36 to 42 in................... $7.50 \quad 70.00$

\section{J. Scopulorum-Pyramidal Silver Juniper.}

Beautiful silvery blue color and narrow, compact and symmetrical. It has one single stem in contrast to some Junipers with several stems. This makes it safe from heavy snows or winds. The inner foliage does not turn brown.

\begin{tabular}{|c|c|}
\hline & Each \\
\hline 36 to 42 in. &.$\$ 6.00$ \\
\hline o 48 in. & 7.50 \\
\hline 48 to $54 \mathrm{in}$. & 10.00 \\
\hline
\end{tabular}

\section{J. Chinese Pfitzeriana-Pfitzer's Juniper.}

The finest of all evergreens for foundation and border plantings. Its adaptability to various conditions and soils is amazing. As to appearance, it is very graceful because of its low, irregular form. It has a blue-green cast to the foliage which, when added to the graceful form, makes it one of the most desirable evergreen. in our whole list.
Each
24 to 30 in............ 7.00
Per 10
24 to 30 in............. \$ 7.00
$\$ 65.00$
36 to 42 in........... $12.50 \quad 100.00$
Specimens, each......\$15.00 to $\$ 25.00$

\section{J. Sabina-Savin Juniper.}

A very dark green, spreading type of the Juniper family. Ideal for foundations, for groups and low borders.

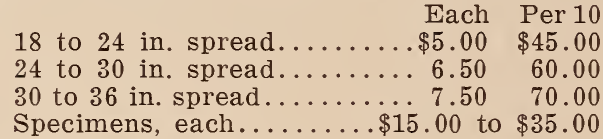

\section{J. Sabina Tamarlsifolia.}

A trailing variety of Sabina. The needle shaped leaves have a very $p^{\top}$ easing shade of gray green. Fine for edging.

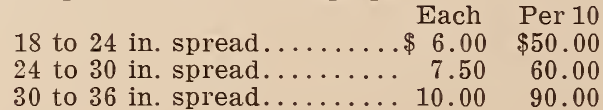

\section{J. Sabina Horizontalis.}

Similar to Sabina excepting that it grows more flat.

42 to 48 in ......... $\$ 10.00 \quad \begin{aligned} & \text { Per } 10 \\ & \$ 90.00\end{aligned}$

Specimens, each.......\$15.00 to $\$ 25.00$

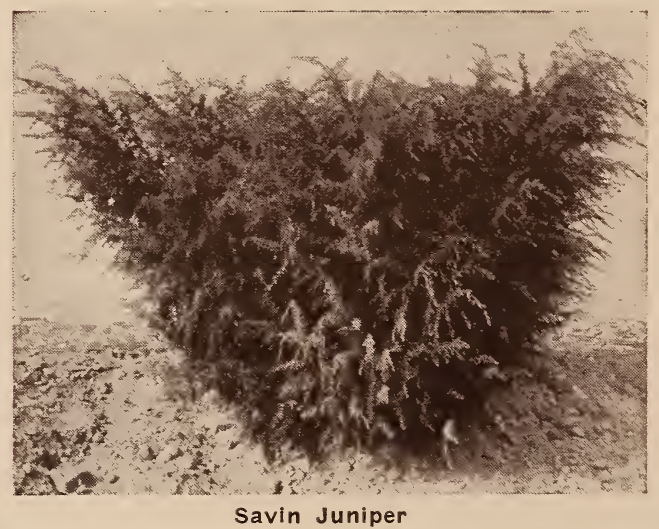




\section{J. Stricta-Spring Greek Juniper.}

Close growing, pyramidal form with graygreen foliage. Excellent in formal gardens.

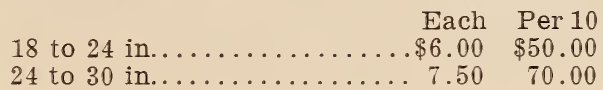

\section{J. Virginia-Red Cedar.}

A well known American tree which varies much in habit and color of foliage, some being conical, regular and quite stiff and others loose and irregular. Makes a fine ornamental hedge plant.

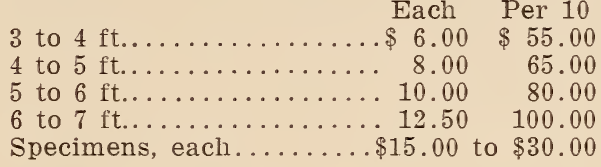

\section{J. Virginia Counarti.}

A fine, pyramidal, compact grower of dark green appearance. Some of the branches lengthen out and droop, thus presenting a very novel and pretty picture.

Each Per 10 $\ldots \ldots \ldots \ldots . \$ 17.50 \quad \$ 150.00$

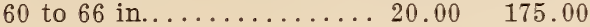
Specimens, each....... $\$ 22.50$ to $\$ 35.00$

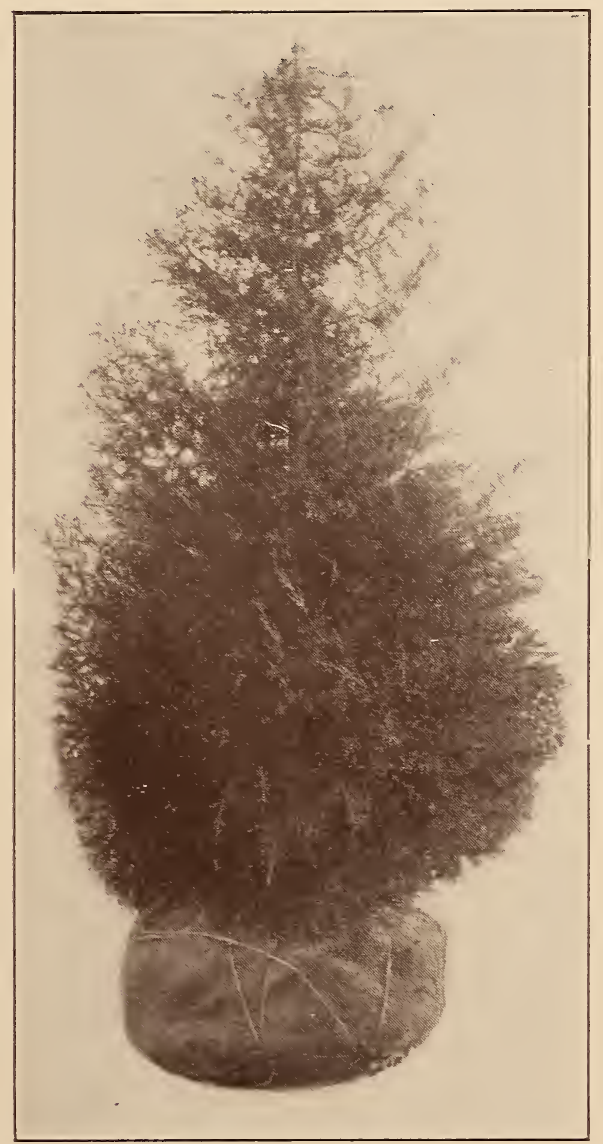

Red Cedar

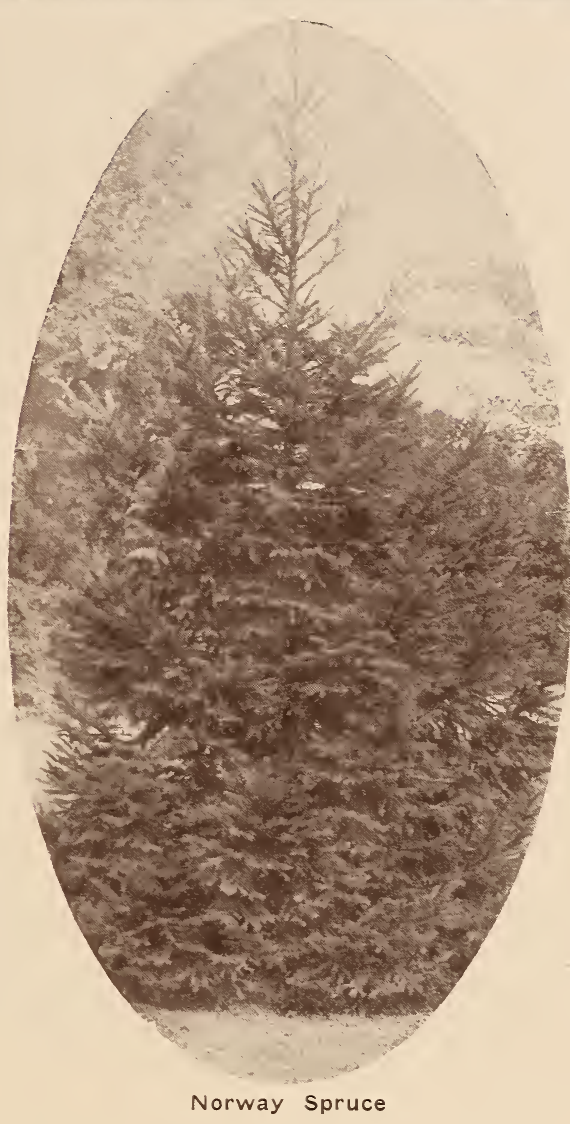

\section{J. Virginiana Glauca-Blue Cedar.}

This tree is sometimes called the Blue Juniper. Its rich, light blue, silvery foliage makes it attractive the entire season, and is one of the finest blue types of the evergreen family.

Each Per 10

42 to 48 in............. \$17.50 \$150.00

48 to 54 in............. 20.00 175.00

Specimens, each....... $\$ 25.00$ to $\$ 35.00$

\section{J. Virginiana Schottii.}

Much more dense and compact in its growth than the Red Cedar; makes a beautiful specimen for a background for evergreen clumps. Its foliage is a rich, dark green.

Each Per 10

54 to 60 in............\$17.50 \$150.00

60 to 66 in...........20.00 175.00

Specimens .......... $\$ 22.50$ to $\$ 30.00$

\section{PICEA Excelsa-Norway Spruce.}

This is more generally used than any other evergreen tree. Useful for screens and windbreaks on account of its rapid growth. It makes a tall tree and with room to develop, will show 


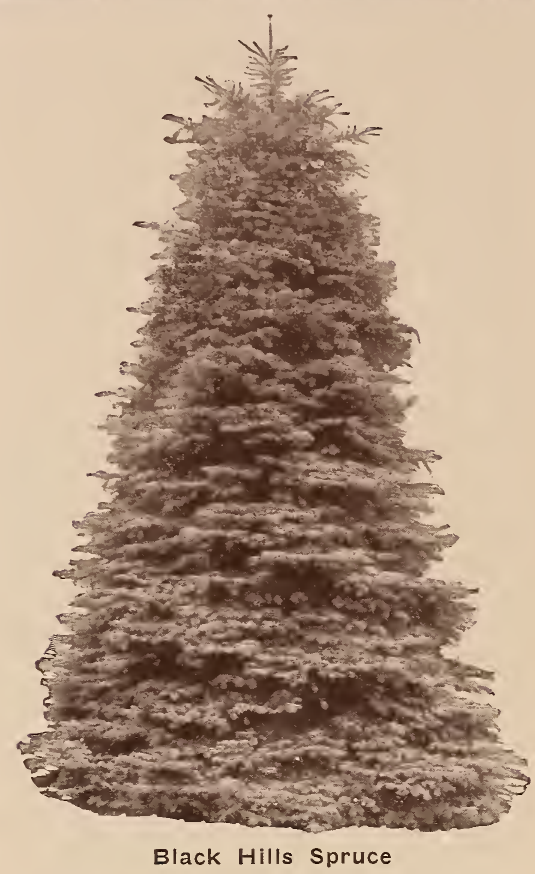

a pyramidal, symmetrical growth, with its lower branches sweeping the ground.

Each Per 10

18 to 24 in..............\$2.00 \$17.50

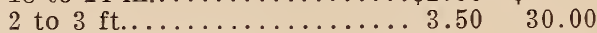

3 to $4 \mathrm{ft} . \ldots \ldots \ldots \ldots \ldots \ldots 6.6 \ldots \ldots \ldots$

4 to $5 \mathrm{ft} . \ldots \ldots \ldots \ldots \ldots \ldots .8 .00 \quad 70.00$

\section{P. Engelmani Glauca-Engleman's Spruce.}

A choice and valuable Rocky Mountain tree of dense, pyramidal growth. Has the stiff foliage of Picea pungens and in most cases, the fine glaucous color of the latter. Hardy in practically every part of the country.

\section{Each Per 10}

30 to 36 in............ \$10.00 \$90.00

36 to 42 in................... $12.50 \quad 100.00$

\section{P. Canadensis-Black Hill Spruce.}

A small tree, but very handsome, having slender, pendulous branches. Very dense and compact. Suitable for cold climates and light, dry soils.

\begin{tabular}{|c|c|}
\hline & Each \\
\hline 18 to 24 in. &.$\$ 2.50$ \\
\hline $\mathrm{N}^{\circ}$ & 3.50 \\
\hline n. & 5. \\
\hline in. & 7.00 \\
\hline & 8.50 \\
\hline
\end{tabular}

\section{P. Alba-White Spruce.}

Compact, upright and long-lived is this beautiful spruce. Retains its branches to the ground. Is aromatic, drought resisting and in color is light green to a glaucous blue.

Each Per 10

30 to 36 in............ \$5.00 \$45.00

36 to 42 in...................... $7.00 \quad 65.00$

42 to 48 in.............. $8.50 \quad 80.00$
P. Pungens Glauca (Green Form)-Colorado Blue Spruce.

This is the best and most attractive of the blue spruces. Foliage is a silvery blue, densely crowded on the many branches.

Each Per 10

24 to 30 in............ \$6.50 \$60.00

Specimens, each.......\$10.00 to $\$ 25.00$

\section{P. Pungens Glauca (Blue Form)-Colorado Blue Spruce.}

These are the extra select blue plants selected from Colorado seedlings.

Each Per 10

24 to 30 in............\$9.00 $\$ 80.00$

Specimens, each.......\$17.50 to $\$ 35.00$

\section{J. Pungens Kosteriana-Koster's Blue Spruce.}

Magnificent, with a silvery blue sheen. Hardy in any exposure, of vigorous growth and elegant habit, with broad branches. Very scarce.

Specimens, each......\$75.00 to $\$ 100.00$

\section{PINUS Austriaca-Austrian Pine.}

A robust, stately tree, of rapid growth. Stiff, long dark green leaves in pairs.

Each Per 10

2 to 3 ft...............\$4.50 $\$ 40.00$

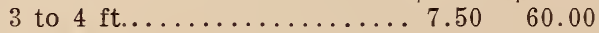

4 to $5 \mathrm{ft} . \ldots \ldots \ldots \ldots \ldots \ldots . \ldots 9.00 \quad 80.00$

Specimens, each.......\$12.50 to $\$ 50.00$

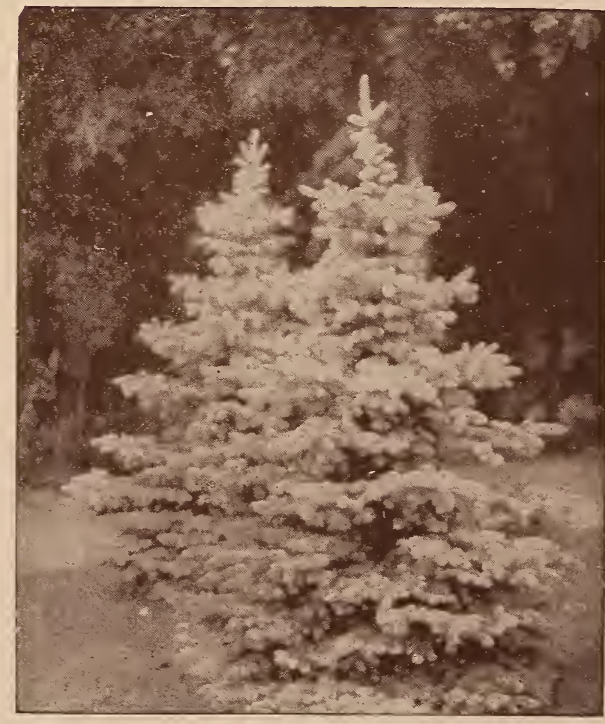

Koster Blue Spruce 


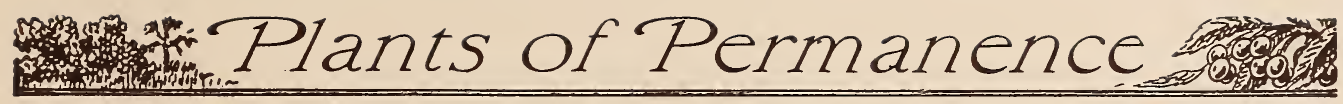

\section{P. Cembra-Swiss Stone Pine.}

A distinct type, resembling somewhat the White Pine, although its needles are not so long-plus the fact that it is a better lawn tree than the White Pine. Grows conical and makes an excellent shaped tree. It is very slow growing.

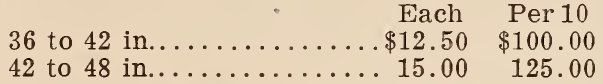

\section{P. Mughus-Mugho or Dwarf Pine.}

A unique, Alpine species, broader than its height and sometimes almost prostrate. Forms a dark, dome shaped bush of about 5 to 8 feet broad. Used for planting on rocky banks, terrace slopes and small lawns. Particularly fine when grown at the corner of entrances.

Each Per 10

15 to 18 in. spread........\$5.00 $\$ 45.00$

18 to 24 in. spread........6.50 60.00

24 to 30 in. spread........ 7.50 70.00

\section{P. Ponderosa-Bull Pine.}

An extremely handsome ornamental tree with long needles of deep green color on the surface, tinted bluish-white underneath. This is the nost widely distributed evergreen in North America.

Each Per 10

4 to $5 \mathrm{ft} . \ldots \ldots \ldots \ldots \ldots \ldots \ldots 8.00 \quad \$ 75.00$

Specimens, each........\$10.00 to $\$ 25.00$

\section{P. Strobus-White Pine.}

This tree is perhaps the most ornamental of our native pines. The foliage is light, delicate

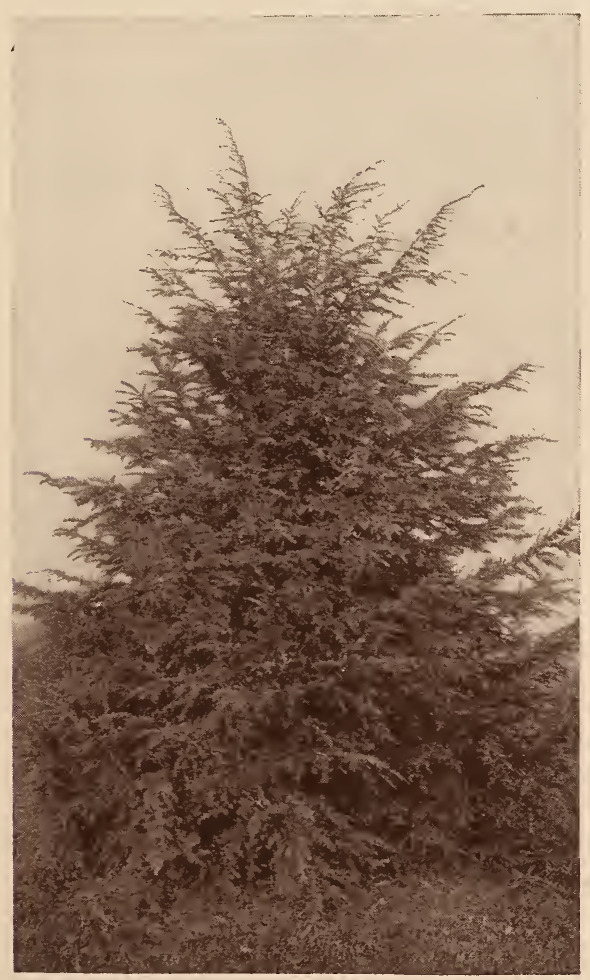

Hemlock Spruce

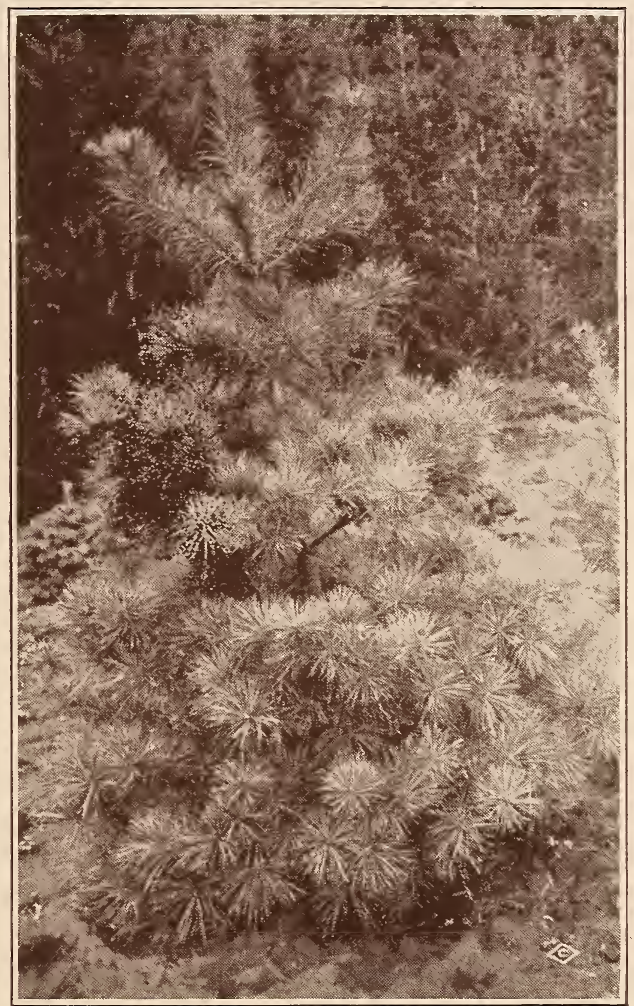

White Pine

or silvery green. Flourishes in the poorest, light sandy soil.

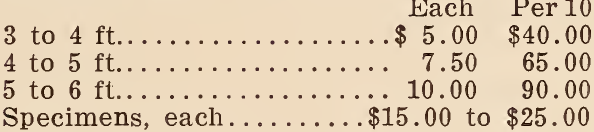

\section{P. Sylvestris-Scotch Pine.}

This evergreen is a native of the British Isles. It is robust, fast growing tree, with stout, erect shoots and silvery green foliage. Very hardy.

Each Per 10

2 to $3 \mathrm{ft} \ldots \ldots \ldots \ldots \ldots \ldots \ldots . \ldots 4.00 \$ \$ 35.00$

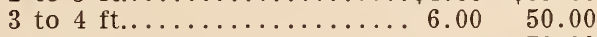

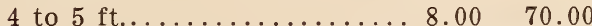

Specimens, each.......\$10.00 to $\$ 35.00$

\section{PSEUDOTSUGA Douglasii-Douglas Spruce.}

This tree grows in a large conical form, with branches spreading, horizontal. Leaves are light green above, glossy blue tint below. A rapid growing tree, very hardy and valuable for its adaptability to many situations.

Each Per 10

2 to $3 \mathrm{ft} . \ldots \ldots \ldots \ldots \ldots \ldots \ldots 5.00 \$ \ldots 45.00$

3 to $4 \mathrm{ft} . \ldots \ldots \ldots \ldots \ldots \ldots 6.50 \quad 60.00$

4 to $5 \mathrm{ft} . \ldots \ldots \ldots \ldots \ldots . \ldots 9.00 \quad 80.00$

Specimens, 5 to $8 \mathrm{ft}$, each. $\$ 12.50$ to $\$ 35.00$ 


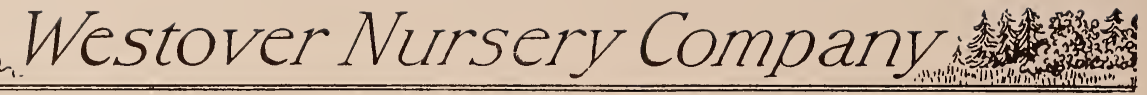

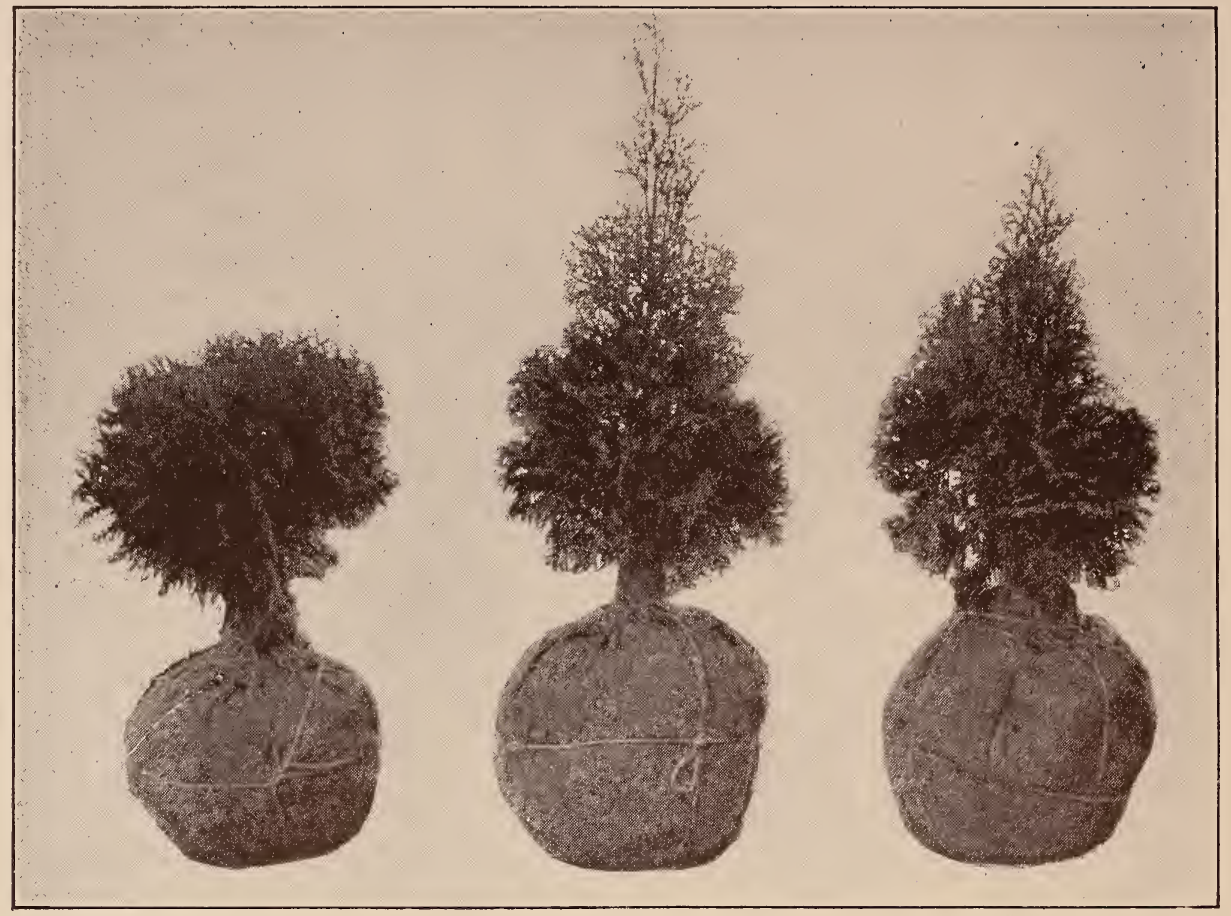

Globe Arbor Vitae

Arbor Vitae Pyramidalis

American Arborvitae

TAXUS Cuspidata-Yew.

One of the hardiest of yews. Has short, dark green leaves. A very handsome, hardy variety. Rare.

Each Per 10

18 to 24 in..............\$6.50 $\$ 60.00$

24 to 30 in.............. $8.00 \quad 75.00$

THUYA-Occidentalis-American Arborvitae.

A beautiful, native tree commonly known as the white cedar. Especially valuable for screens and hedges.

\begin{tabular}{|c|c|c|}
\hline 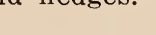 & Each & Per 10 \\
\hline 18 to $24 \mathrm{in}$. &.$\$ 2.50$ & $\$ 22.50$ \\
\hline to $3 \mathrm{ft} . .$. & .4 .00 & 35.00 \\
\hline to $4 \mathrm{ft}$. & 5.50 & 50.00 \\
\hline 4 to $5 \mathrm{ft}$. & 7.50 & 70.00 \\
\hline
\end{tabular}

T. Occidentalis Globosa-Globe Arborvitae.

Same shade as pyramidalis. This variety grows perfectly round without shearing.

Each Per 10

15 to 18 in. spread.........\$3.50 $\$ 30.00$

18 to 24 in. spread............. $5.00 \quad 40.00$

24 to 30 in. spread.........6.50 60.00

\section{T. Occidentalis Wareana-Siberian Arbor-} vitae.

Of upright pyramidal compact habit, foliage dark green; very desirable.

Each Per 10

24 to 30 in.............\$6.00 $\$ 50.00$

30 to 36 in.................... $7.00 \quad 60.00$

36 to 42 in.............. $8.00 \quad 75.00$
T. Occidentalis Pyramidalis-Pyramidal Arborvitae.

This evergreen resembles the Irish Juniper in growth, being tall, forming a slender column of dark green. Retains its color in winter. Very hardy.

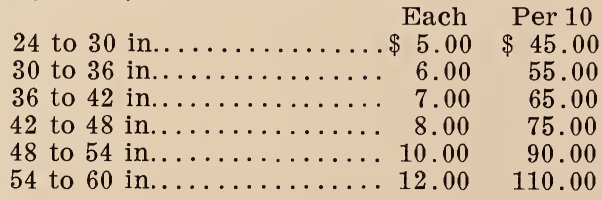

\section{T. Occidentalis Woodwardii-Woodward's Globe Arborvitae.}

This is one of the best globe forms of the Thuyas.

\section{Each Per 10}

15 to 18 in. spread........\$6.50 $\$ 60.00$

18 to 24 in. spread......... $7.50 \quad 70.00$

\section{TSUGA Canadensis-Hemlock Spruce.}

A broad, pyramidal, medium sized tree of dense growth, with rich green foliage. Branches are thickly set, with more less pendulous tendency, giving a very graceful effect to the whole.

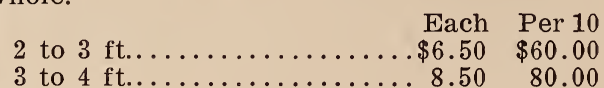




\section{Evergreeen Shrubs}

\section{BERBERRIS Ilicifolia-Holly Leaved Bar- berry.}

An ornamental shrub with holly leaf like foliage which remains on the plant practically all winter.

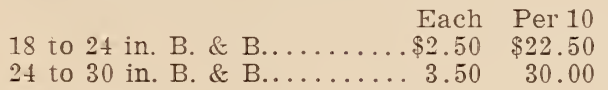

\section{EUONYMUS Sieboldi.}

Shrub or small tree which bears beautiful scarlet fruit in the fall.

$$
\begin{aligned}
& \text { Each Per } 10 \\
& 3 \text { year .............\$0.75 \$7.00 }
\end{aligned}
$$

\section{ILEX Opaca-American Holly.}

A very ornamental shrub with upright branches and light green foliage; its bright scarlet berries remaining on the branches until mid-winter.

24 to 30 Each Per 10

$\$ 65.00$

3 to $4 \mathrm{ft} .$, B. \& B......... $10.00 \quad 90.00$

4 to $5 \mathrm{ft} .$, B. \& B......... 15.00 125.00

Specimens, each .......\$17.50 to $\$ 30.00$

MAHONIA Aquifolia-Holly-leaved Mahonia.

Desirable for undergrowth in Evergreen shrub planting. Rich green foliage which turns bronze in the fall.

Each Per 10

18 to 24 in.. B. \& B........ \$2.50 \$22.50

24 to 30 in.. B. \& B....... $3.50 \quad 30.00$

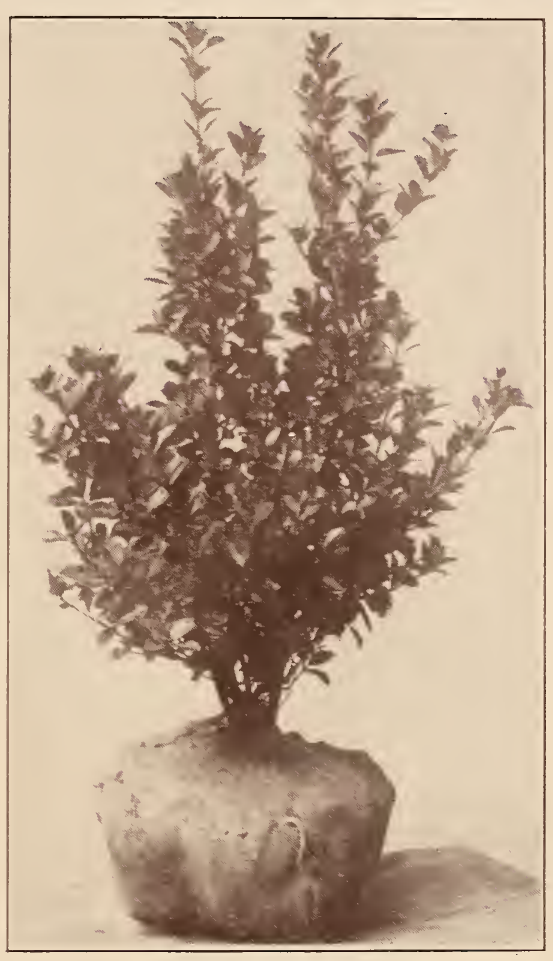

Euonymus

\section{Deciduous Shrubs}

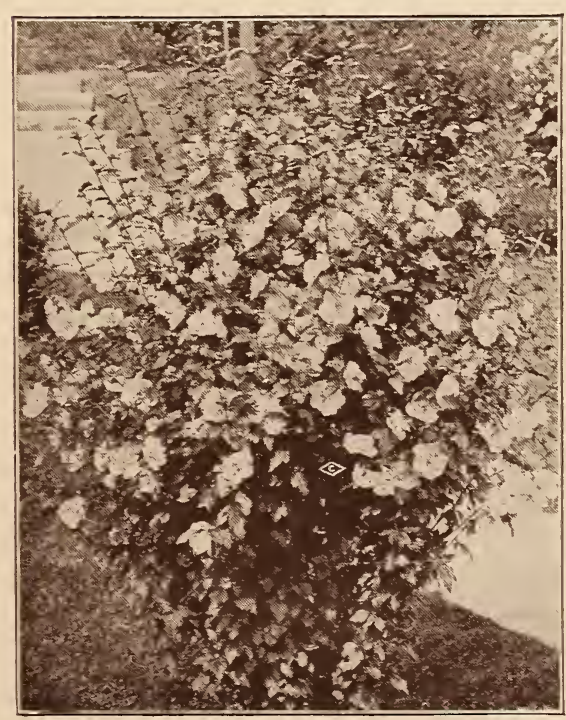

Althea
ALTHEA Syn. Hibiscus-Rose of Sharon.

The Altheas are fine, free-growing shrubs of very easy cultivation, and very desirable, principally on account of their flowering in August and September, a time when nearly all other trees and shrubs are out of bloom.

Prices on all Althea, except where noted: Each Per 10 Per 100

2 to $3 \mathrm{ft} . \ldots \ldots \ldots \ldots .60 \quad \$ 5.00 \quad \$ 40.00$

3 to $4 \mathrm{ft} \ldots \ldots \ldots \ldots \ldots . .6 \% \quad 75 \quad 7.00 \quad 60.00$

\section{A. Syriacus Anemoneflora.}

Semi-double red.

A. Syriacus Boule de Feu.

Double red.

\section{A. Syriacus Ardens.}

Double violet, large flowers; petals quilled.

\section{A. Syriacus Jeanne d'Arc.}

Double white. 


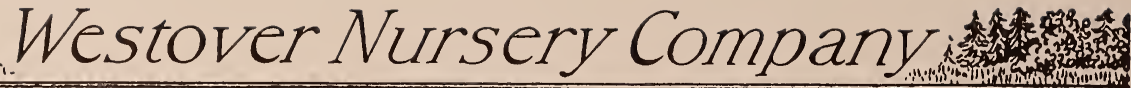

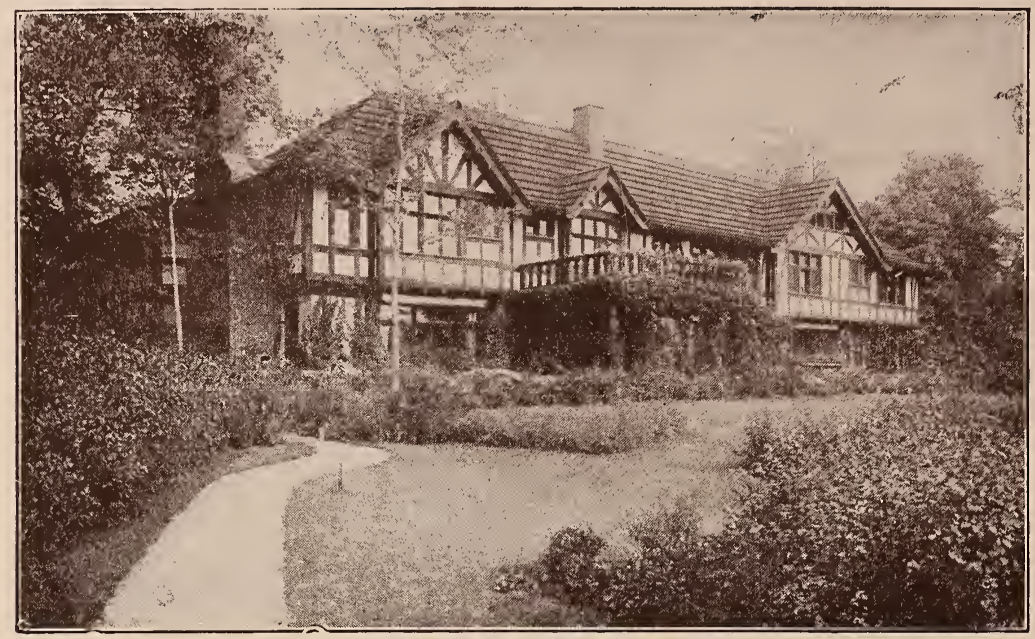

An Attractive Shrub Planting

\section{A. Syriacus Lady Stanley.}

Very double, white with beautiful blush markings, red base.

\section{A. Syriacus Totus Albus.}

Single white.

\section{A. Syriacus Paeoneflora.}

Double white, red center.

\section{A. Purpurea Semi-plena.}

Semi-double, purplish red.

\section{A. Variegata-Variegated-Leaved Althea.}

This is one of the handsomest variegated leaved shrubs that grows. Foliage white and green, flowers red.

Each Per 10

18 to 24 in..............\$0.75 $\$ 7.00$

2 to $3 \mathrm{ft} . \ldots \ldots \ldots \ldots \ldots \ldots 1.00 \quad 9.00$

\section{AMELANCHIER Botryapium-Dwarf June-}

berry.

White flowers-very suited where wild effects are wanted, also for partially shaded places and shallow, rocky soils.

Each Per 10

2 to $3 \mathrm{ft} \ldots \ldots \ldots \ldots \ldots \ldots \ldots .60$

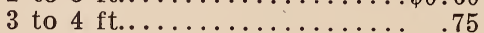

$\$ 5.50$

6.50

A. Canadensis-Serviceberry.

Each Per 10

2 to $3 \mathrm{ft} . \ldots \ldots \ldots \ldots \ldots$

$\$ 5.50$

3 to $4 \mathrm{ft} . \ldots \ldots \ldots \ldots \ldots \ldots \ldots \ldots \ldots \ldots \ldots \ldots \ldots . .75$

4 to $5 \mathrm{ft} . \ldots \ldots \ldots \ldots \ldots \ldots . .90$

6.50

8.00

\section{AMORPHA Fruiticosa-Indigo Shrub.}

Grows from 6 to 10 feet tall and forms a large, spreading bush, with compound leaves, containing 10 to 20 bright green leaflets and slender spikes of deep violet-blue flowers in June.

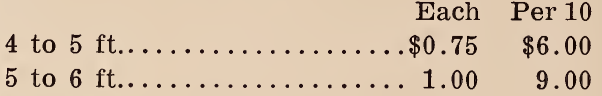

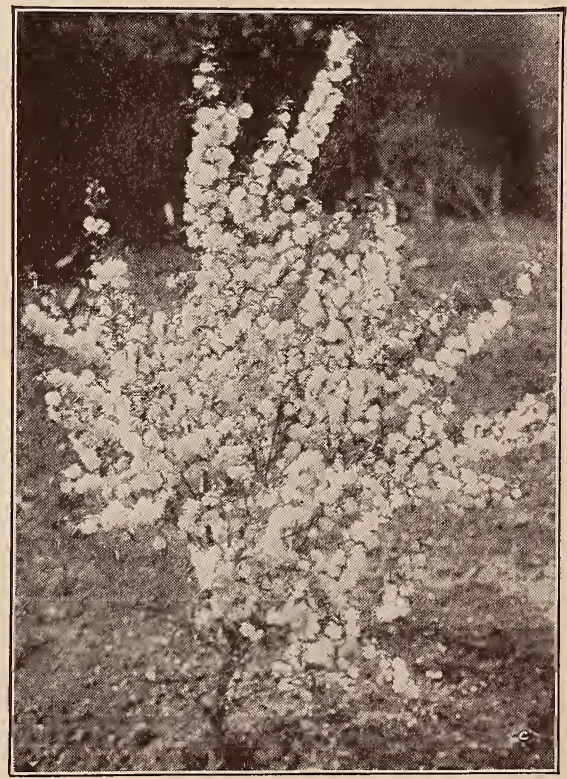

Flowering Almond 


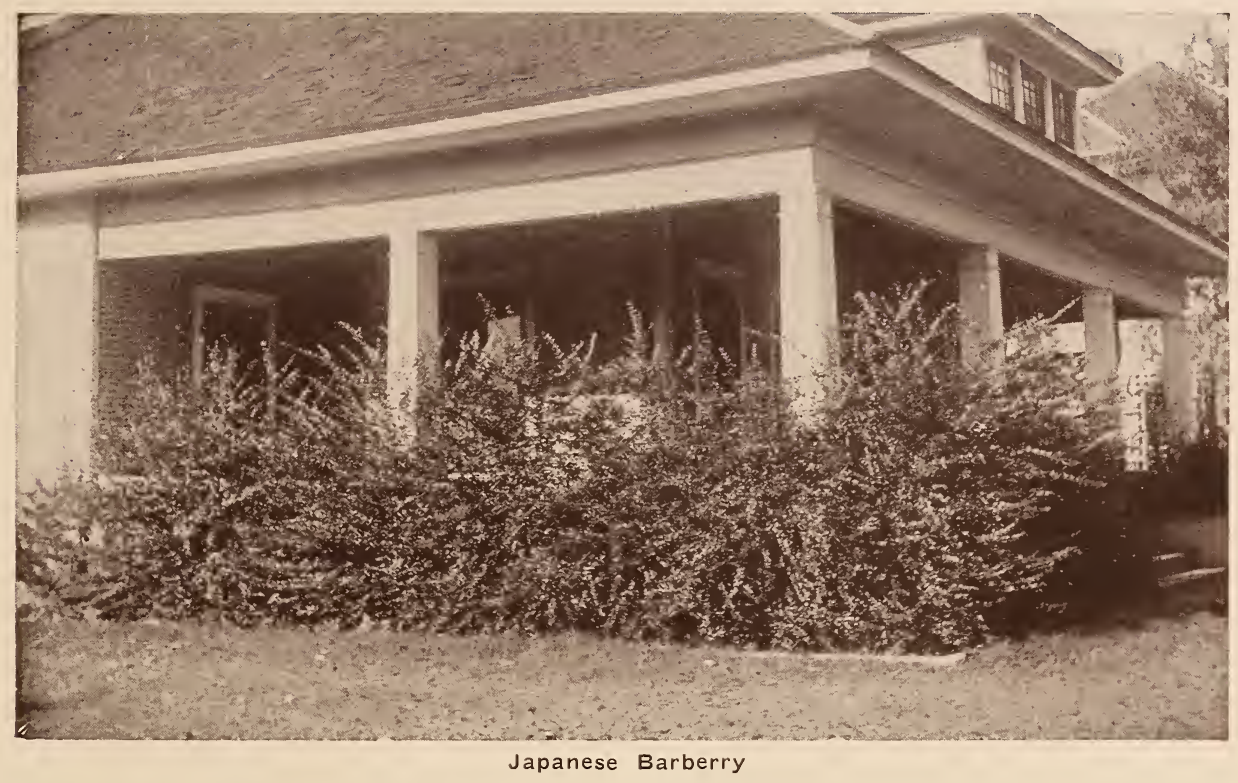

\section{AMYGDALUS Alba-White Flowering Almond.}

Very heavy with double, rose-like white flowers, which fill the branches until they bend with the weight of the bloom.

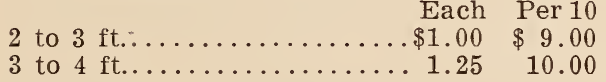

\section{A. Rosea-Pink Flowering Almond.}

Similar to the White Flowering Almond, except that the flowers are rose-colored.

Each Per 10

2 to $3 \mathrm{ft} . \ldots \ldots \ldots \ldots \ldots \ldots . \ldots 1.00 \$ 9.00$

3 to $4 \mathrm{ft} . \ldots \ldots \ldots \ldots \ldots \ldots \ldots 1.25 \quad 10.00$

\section{ARALIA Pentaphylia.}

This beautiful shrub has slender, prickly branches, good crown, and handsome autumn foliage. Does very well in shady places-can be used under trees. Flowers are an odd greenish-white, being borne in clusters. Foliage is a rich, glossy green.

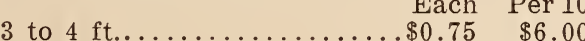
4 to $5 \mathrm{ft} . \ldots \ldots \ldots \ldots \ldots \ldots \ldots . .90 \quad 8.00$

\section{A. Spinosa-Hercules Club.}

Has stout prickly stems, the foliage is finely divided and out of the top are borne large white spiky flowers.

3 to $4 \mathrm{ft} . \ldots \ldots \ldots \ldots \ldots \ldots 1.0 \ldots \ldots$ Each $\begin{array}{r}\text { Per } 10 \\ \$ 9.00\end{array}$

\section{ARONIA Arbutifolia-Chokeberry.}

A beautiful, densely branched shrub bearing clusters of white flowers in May, followed by extremely ornamental red berries.

Each Per 10

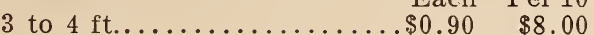

4 to $5 \mathrm{ft} . \ldots \ldots \ldots \ldots \ldots \ldots \ldots . \ldots 1.00 \quad 9.00$
A. NIGRA-Black Chokeberry.

Same description as above excepting black berries.

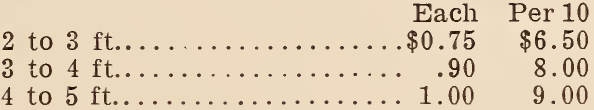

BENZOIN Aestivallis Lindera-Spice Bush.

Tall growing shrub, has handsome flowers and red fruit.

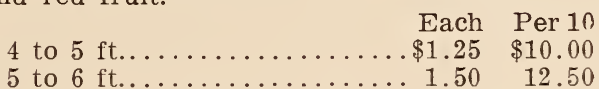

\section{BERBERIS Thunbergii-Japanese Barberry.}

A species from Japan, with round, drooping habit, spoon shaped leaves, of a fine brilliant green in summer, with the growing shoots always a lighter shade, and taking on, from Autumn till December, the most glowing colors. They make a dense, low hedge, which will stand any amount of shearing, and are very hardy. No more beautiful or practical shrub than this grown.

$\begin{array}{rrrr}18 \text { to } 24 \text { in........ Each } & \text { Per } 10 & \text { Per } 100 \\ 24 \text { to } 30 \text { in...60 } & \$ 4.50 & \$ 40.00 \\ 30 \text { to } 36 \text { in.......... } & .70 & 6.00 & 50.00 \\ & .80 & 7.00 & 60.00\end{array}$

\section{BUDDLEIA Variabilis Veitchii-Butterfly} Bush.

One of the most admired of shrubs. Very bushy and grows quickly. Bloom spikes appear in August and radiate a delightful perfume. Freezes down in winter but grows again rapidly in the spring. Attains a height of five feet in July.

$\begin{array}{rr}2 \text { year, field grown........ Each } & \begin{array}{r}\text { Per } 10 \\ \$ 0.55\end{array} \\ \$ 5.00\end{array}$




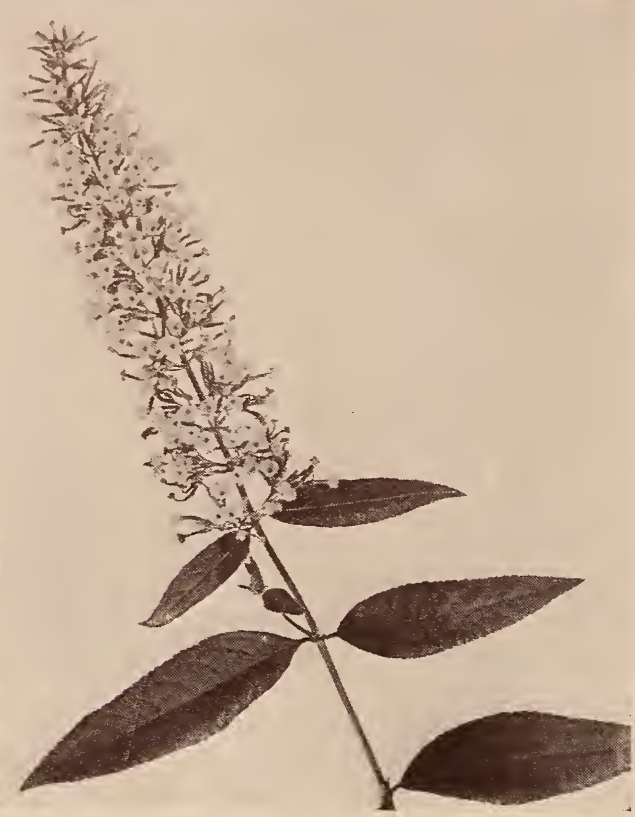

Summer Lilac or Butterfly Bush

CALLICARPA Purpurea-Beauty Fruit.

Graceful slender branches; small flowers in fall, followed by violet berries; very showy. Each Per 10

2 to $3 \mathrm{ft} . \ldots \ldots \ldots \ldots \ldots \ldots \ldots 0.65 \quad \$ 5.50$

3 to $4 \mathrm{ft} . \ldots \ldots \ldots \ldots \ldots \ldots \ldots . .75 \quad 7.00$

CALYCANTHUS Floridus-Strawberry Shrub or All-Spice.

This is a small, old-fashioned shrub, the chocolate colored blossoms of which are very sweet scented and spicy, resembling the odor of strawberries. Flowers are double, growing from the base of the leaves, which are rough and a handsome green above.

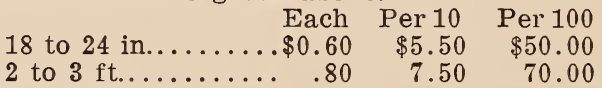

CARAGANA Arborescens-Siberian Pea Tree. Makes a very handsome show in the late spring with its bright green foliage and numerous small clusters of bright, yellow flowers. Perfectly hardy and valuable for either group or individual planting.

Each Per 10

3 to $4 \mathrm{ft} . \ldots \ldots \ldots \ldots \ldots \ldots \ldots . \ldots \ldots . \ldots \ldots \ldots$

4 to $5 \mathrm{ft} . \ldots \ldots \ldots \ldots \ldots \ldots . .80 . \ldots \ldots$

5 to $6 \mathrm{ft} \ldots \ldots \ldots \ldots \ldots \ldots \ldots$

CEPHALANTHUS Occidentalis-Button Bush.

This is a native shrub, having globular heads of white flowers in July. Height 3 to 6 feet. Each Per 10 Per 100

3 to $4 \mathrm{ft} . \ldots \ldots \ldots \ldots \$ 0.65 \quad \$ 6.00 \quad \$ 50.00$

4 to $5 \mathrm{ft} . \ldots \ldots \ldots \ldots . . . . . .60 \quad 7.00 \quad 65.00$

CHIONANTHUS Virginica-White Fringe.

A small, tree like shrub, much admired for its curious fringe or hair-line flowers that cover the whole surface in mid-summer.

Each Per 10

18 to 24 in ............ \$1.00 \$7.50

2 to $3 \mathrm{ft} . \ldots \ldots \ldots \ldots \ldots \ldots \ldots . \ldots \ldots$

Page Thirty
CLETHRA Almifolia-Sweet Pepper Bush.

This is a native bush, growing low and dense, with light green, abundant leaves. Has numerous spikes of small white, fragrant flowers which bloom in great abundance in July.

\begin{tabular}{|c|c|c|c|}
\hline & Each & Per 10 & Per 100 \\
\hline 5 to 18 in.. & $\$ 0.50$ & $\$ 4.50$ & $\$ 40.00$ \\
\hline 4 in. & .65 & 5.50 & 50.00 \\
\hline to : & .75 & 6.50 & 60.00 \\
\hline
\end{tabular}

COLUTEA Arborescens-Bladder Senna.

Grows quickly in any dry, sunny place, forming graceful clumps of delicate foliage. Its long racemes of yellow and cinnabar-red peashaped flowers appear in the summer and are followed by large, red seed-shaped pods.

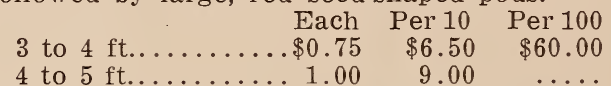

CORNUS Alba Syn. Siberica-Red Siberian

Dogwood or Cornel.

Free-growing, 6 to 10 feet tall and very hardy. Forms a small, handsome tree in some situations. All Siberian Dogwoods bear a profusion of whitish blue berries in early fall, making them distinctly ornamental after the flowers are gone. The stems are red which make it a valuable plant for winter effect.

$\begin{array}{rrrrr}2 \text { to } 3 \mathrm{ft} . \ldots \ldots \ldots \ldots & \text { Each } & \text { Per } 10 & \text { Per } 100 \\ 3 \text { to } 4 \mathrm{ft} . \ldots \ldots \ldots \ldots & .65 & \$ 5.00 & \$ 45.00 \\ 4 \text { to } 5 \mathrm{ft} . \ldots \ldots \ldots \ldots & .80 & 7.00 & 55.00 \\ \end{array}$

C. Alternifolia-Blue Dogwood.

Shrub or small tree about 25 feet high. Flowers creamy white and very fragrant.

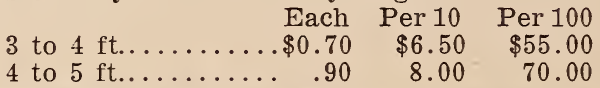

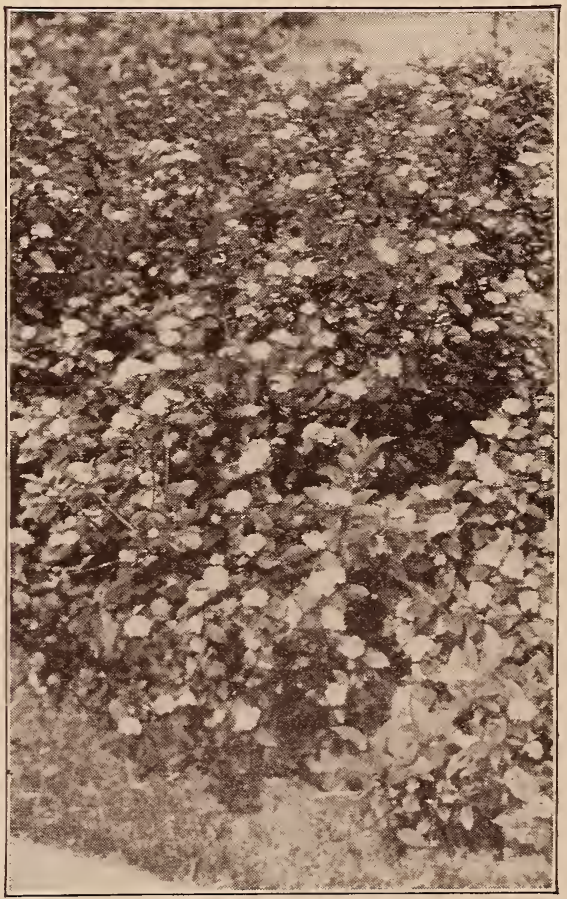

Yellow Twigged Dogwood 


\section{Plants of Permanence}

C. Amomum Syn. Sericea-Silky Dogwood.

Flowers white, fruit blue, branches red and spreading. Flowers bloom in June.

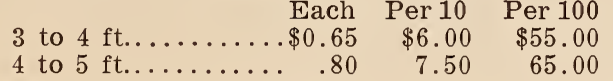

\section{Lutea-Yellow-twigged Dogwood.}

Bright yellow bark in winter, particularly effective in shrubberies planted with the RedBranched Dogwood.

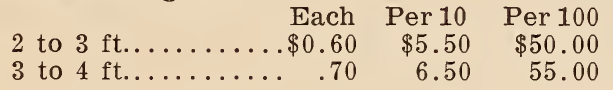

\section{MASCULA-Cornelian Cherry.}

A small tree, producing clusters of bright yellow flowers early in spring, before the leaves, followed by red berries.

$\begin{array}{rrr}\text { Each } & \text { Per } 10 & \text { Per } 100 \\ 3 \text { to } 4 \mathrm{ft} . \ldots \ldots \ldots . \$ 0.90 & \$ 8.00 & \$ \ldots \ldots\end{array}$

\section{Paniculata-Panicled Dogwood.}

Has smooth, ash-colored bark, with pointed leaves, light green above, whitish beneath. Flowers greenish-white; fruit white.

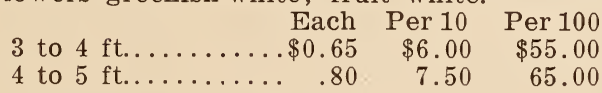

\section{Sanguinea-English Osior.}

Flowers white, fruit black, branches bright red and upright.

\begin{tabular}{|c|c|c|c|}
\hline 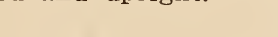 & Each & Per 10 & Per 100 \\
\hline to $4 \mathrm{ft}$. & $\$ 0.65$ & $\$ 6.00$ & $\$ 55.00$ \\
\hline $5 \mathrm{ft}$. & .80 & 7.50 & 65.00 \\
\hline to $6 \mathrm{ft}$. & .90 & 8.00 & 70.00 \\
\hline
\end{tabular}

\section{Stolonifera-Red Osier Dogwood.}

A native species, with smooth slender branches, which are usually red in the winter.

\begin{tabular}{|c|c|c|}
\hline Each & Per 10 & $\mathrm{Pe}$ \\
\hline$\$$ & $\$$ & \\
\hline . & 7 & \\
\hline
\end{tabular}

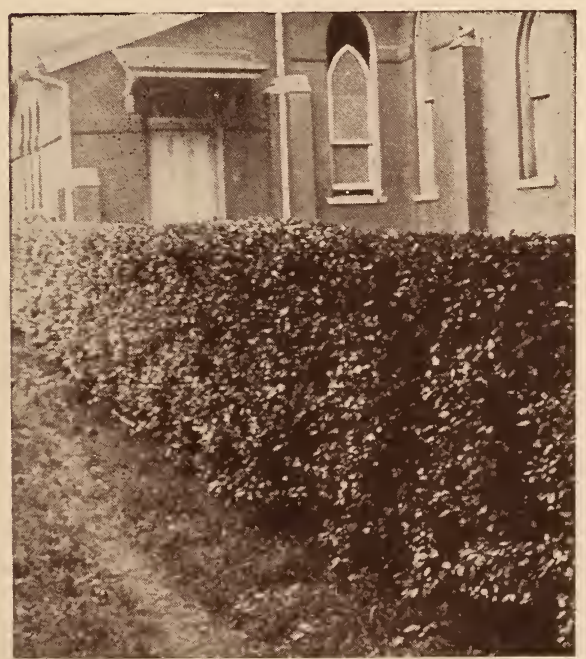

Cotoneaster as Hedge

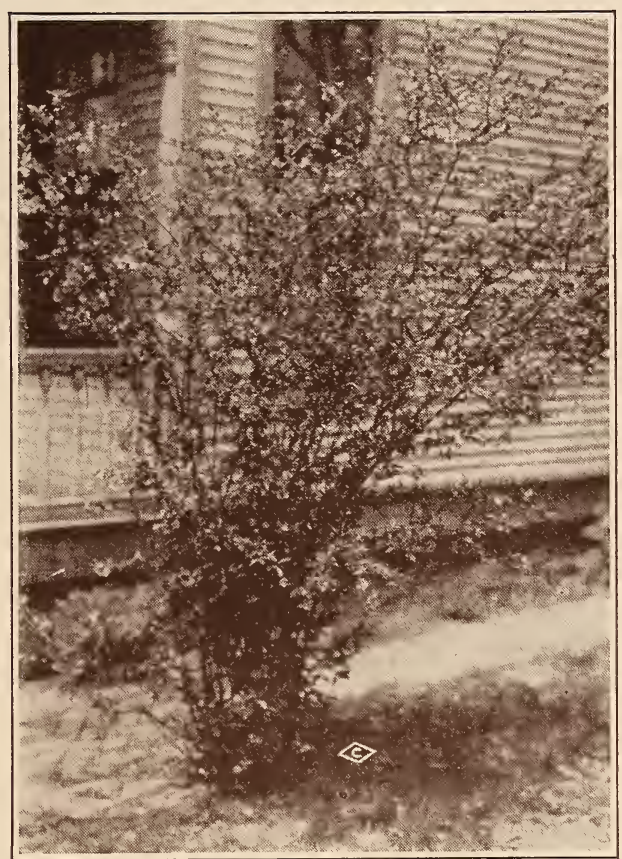

Japan Quince or Fire Bush

CORYLUS Americana-American Hazelnut.

Tall growing border shrub; large dark green leaves; bearing hazelnuts.

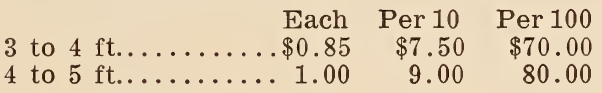

C. Avellana (Horticultural variety of Corylus) Filbert.

A very conspicuous shrub. Valuable in shrubbery borders.

$\begin{array}{rrrr} & \text { Each } & \text { Per } 10 & \text { Per } 100 \\ 3 \text { to } 4 \mathrm{ft} . \ldots \ldots \ldots \ldots \ldots \$ .85 & \$ 7.50 & \$ 70.00 \\ 4 \text { to } 5 \mathrm{ft} \ldots \ldots \ldots \ldots . \$ 1.00 & \$ 9.00 & \$ 80.00\end{array}$

\section{COTONEASTER Acutifolia.}

Shrub to 12 feet, with spreading, slender branches. Flowers May and June. Fruits black in September and October.

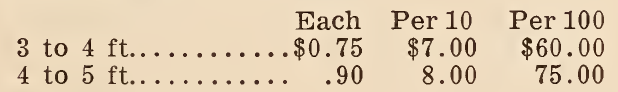

\section{CYDONIA Japonica-Japan Quince or Fire}

Bush.

This fine old shrub is completely covered with dazzling scarlet flowers early in the spring. Leaves are dark green and glossy.

\begin{tabular}{|c|c|c|}
\hline Each & Per 10 & Per 100 \\
\hline$\ldots \$ 0$. & $\$ 8.00$ & $\$ 75.00$ \\
\hline to $4 \mathrm{ft} . .$. & 9.00 & 80.00 \\
\hline
\end{tabular}

DESMONDIUM Penduliforum-Bush Clover.

A low growing shrub with rose-colored flowers in September. Dies to the ground in winter, but is very hardy, growing 3 feet tall the next year. 


\section{Westover Nursery Company}

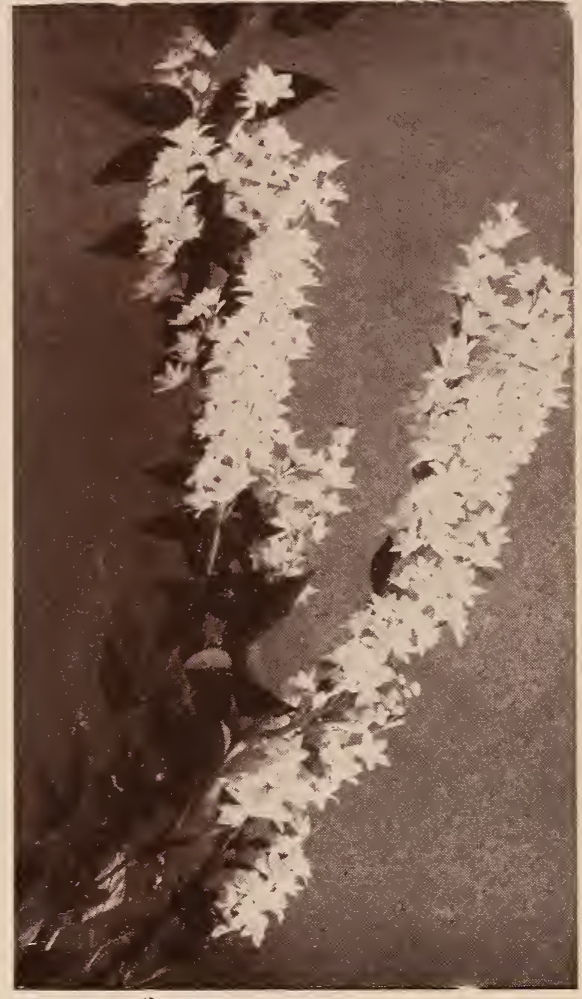

\section{Deutzla}

\section{DEUTZIA-}

No other shrub in the list will yield better returns for a minimum of care than the Deutzia. They vary greatly in height and habit, but all have dainty bell or tassel-shaped flowers borne thickly in wreaths along their branches in June. The taller sorts are useful for specimens. groups and in the background of shrubberies; the dwarfer for borders or for planting near the house or in front of the piazza.

Prices on all Deutzia, except where noted: Each Per 10 Per 100 3 to $4 \mathrm{ft} . \ldots \ldots \ldots \ldots \$ 0.75 \quad \$ 6.00 \quad \$ 5000$ 4 to $5 \mathrm{ft} . \ldots \ldots \ldots \ldots .90 \quad .90 \quad 8.00 \quad 70.00$ 5 to $6 \mathrm{ft} \ldots \ldots \ldots \ldots . .90 \quad 80 \quad 8.00 \quad 75.00$

\section{Crenata.}

Full distinct type; single white.

\section{Crenata Candidissima.}

Double pure white flowers.

\section{Crenata Rosea Plena.}

Double white, tinged pink.

\section{Crenata-Pride of Rochester.}

Grows 6 to 8 feet high, and blooms in May before the others. Flowers large and free. double white.

\section{Gracilis.}

Dwarf growing, dense, bushy, its drooping branches wreathed with pure white flowers in May.

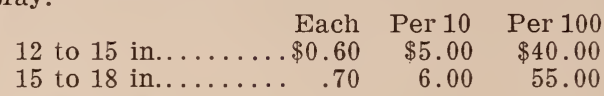

D. Lemoinei.

Medium height, large flowers of pure white in cone shaped heads.

\begin{tabular}{|c|c|c|}
\hline Each & Per 10 & Per 100 \\
\hline.$\$ 0.7$ & $\$ 6.00$ & $\$ 50.00$ \\
\hline . $\quad .9$ & 8.00 & 70 \\
\hline to 42 in.. & 9.00 & 80 \\
\hline
\end{tabular}

\section{ELEAGANUS Hortensis Syn. Augustifolia-}

Russian Olive or Oleaster.

Large silvery green foliage, yellow flowers and yellow fruit. Very desirable for borders.

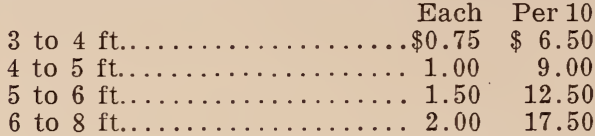

EUONYMUS Americana. Wahoo-Straw. berry or Spindle Tree.

A tall growing shrub with leaves larger than the European, turning to scarlet in autumn. Fruit large, dark red.

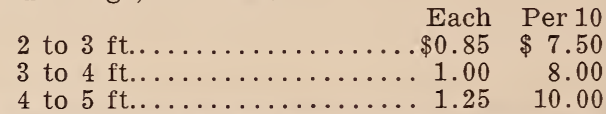

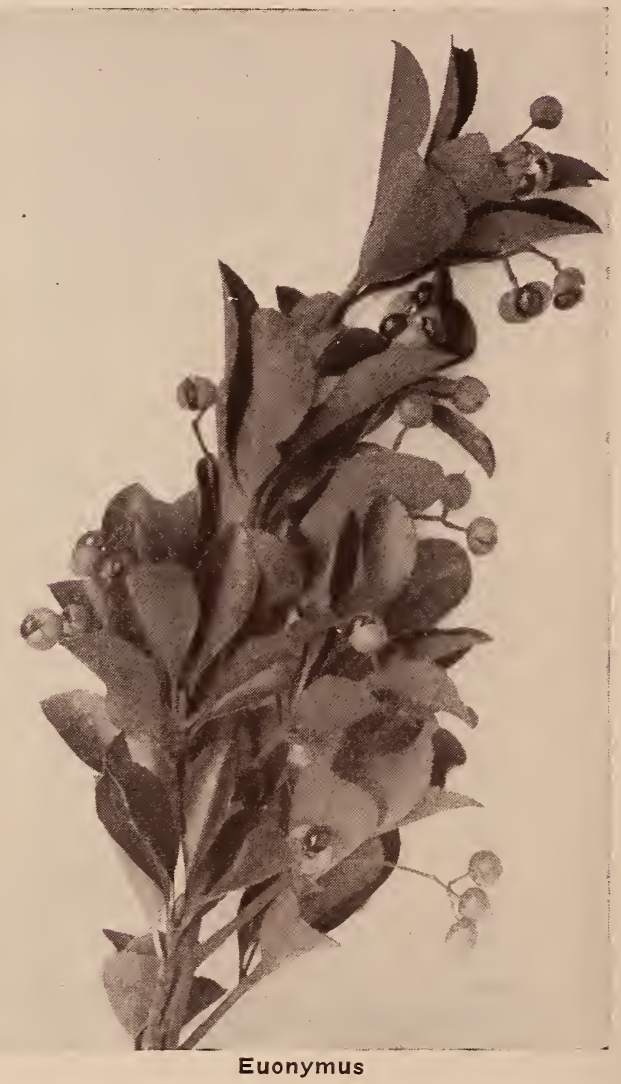




\section{Plants of Permanence}

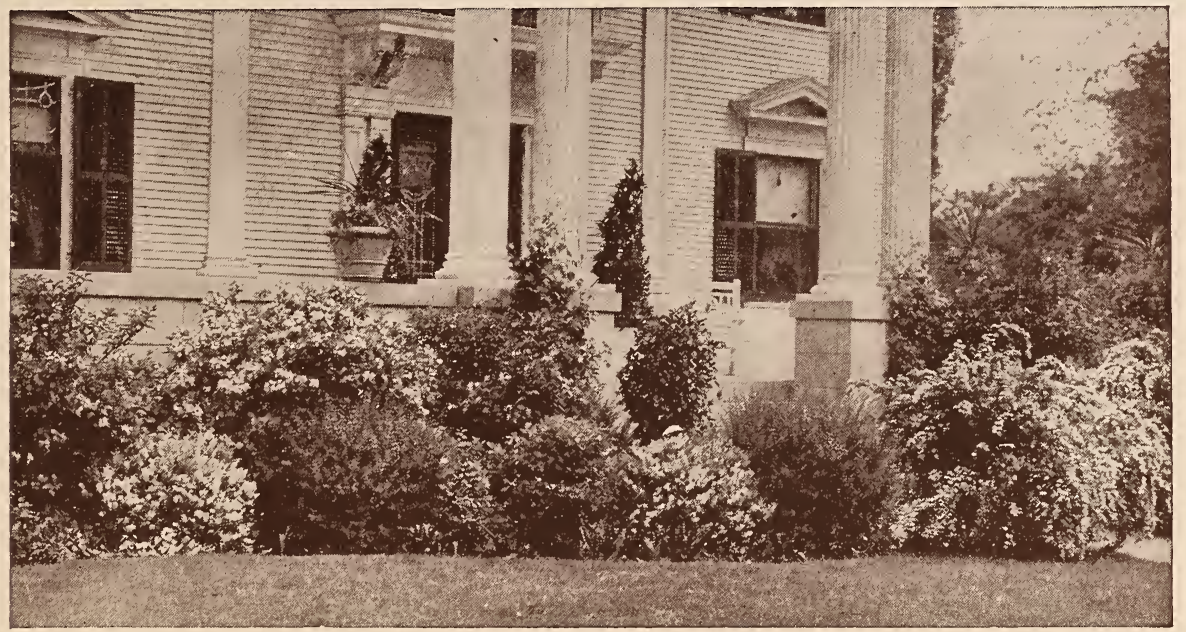

An effective Shrub planting

\section{E. Bungeanus.}

Forms a tree sometimes 30 feet in height. Fruit is yellow which is borne profusely and remains a long time upon the branches.

Each Per 10

3 to $4 \mathrm{ft} . \ldots \ldots \ldots \ldots \ldots \ldots . \ldots 1.00 \quad \$ 8.00$

\section{E. Alatus-Cork-barked Euonymous.}

This shrub has an individuality all its own. Particularly ornamental and interesting on account of its corky bark. Small delicate flowers in the spring are followed by attractive red berries in the fall.

Each Per 10

18 to 24 in .............. $\$ 1.00$

2 to $3 \mathrm{ft} . \ldots \ldots \ldots \ldots \ldots \ldots \ldots \ldots 1.25 \quad 11.00$

3 to $4 \mathrm{ft} \ldots \ldots \ldots \ldots \ldots \ldots \ldots 1.50 \quad 12.50$

\section{EXOCHORDIA Grandiflora-Pearl Bush.}

Comes from North China. A fine shrub, producing large white flowers in May. Difficult to propagate and always scarce, but is very hardy.

Each Per 10

3 to $4 \mathrm{ft} . \ldots \ldots \ldots \ldots \ldots \ldots \ldots \$ 1.25 \$ \$ 10.00$

4 to $5 \mathrm{ft} . \ldots \ldots \ldots \ldots \ldots \ldots \ldots \ldots$

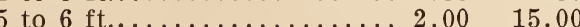

FORSYTHIA Fortunei-Golden Bell.

This splendid old shrub grows from 8 to 10 feet in good soil and will light up the garden with glinting masses of yellow very early in the spring before the leaves appear. Entirely hardy.

Prices on all Forsythia:

Each Per 10 Per 100

3 to $4 \mathrm{ft} . \ldots \ldots \ldots \ldots \$ 0.60 \quad \$ 5.50 \quad \$ 50.00$

4 to $5 \mathrm{ft} . \ldots \ldots \ldots \ldots . .75 \quad 7.00 \quad 60.00$

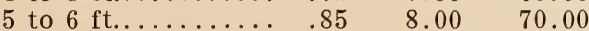

\section{F. Fortunei Aurea-Fortune's Golden Bell.}

Green and yellow foliage; blooms early in the spring, usually with the Crocusses, which are frequently seen planted in front or beneath them. Curving branches sometimes root at their tips; stems and leaves retain their beautiful color until late in the autumn.

\section{F. Viridissima.}

The flowers of this variety are of a little deeper yellow than in other sorts and are sometimes twisted. The leaves are deep green, longer and narrow.

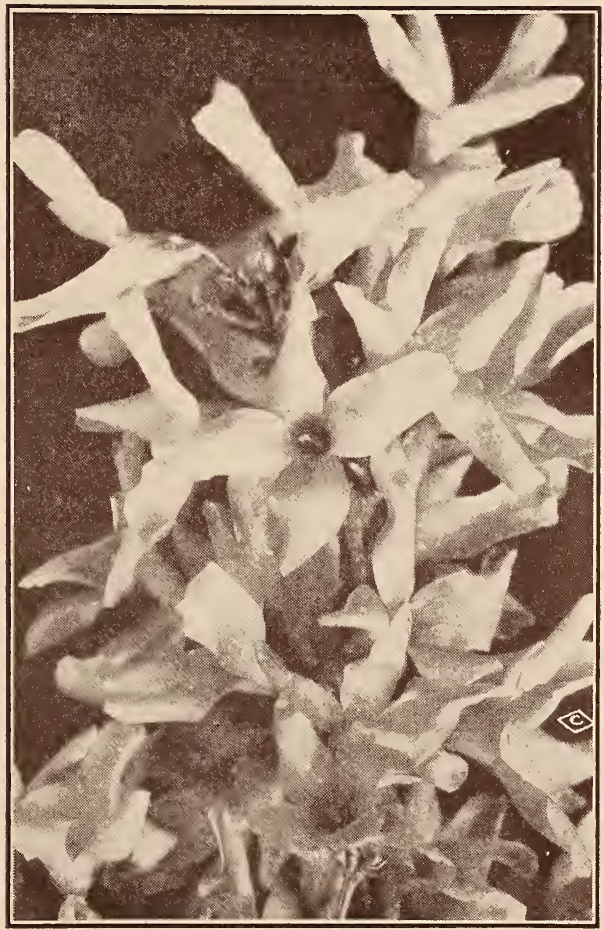

Forsythia 


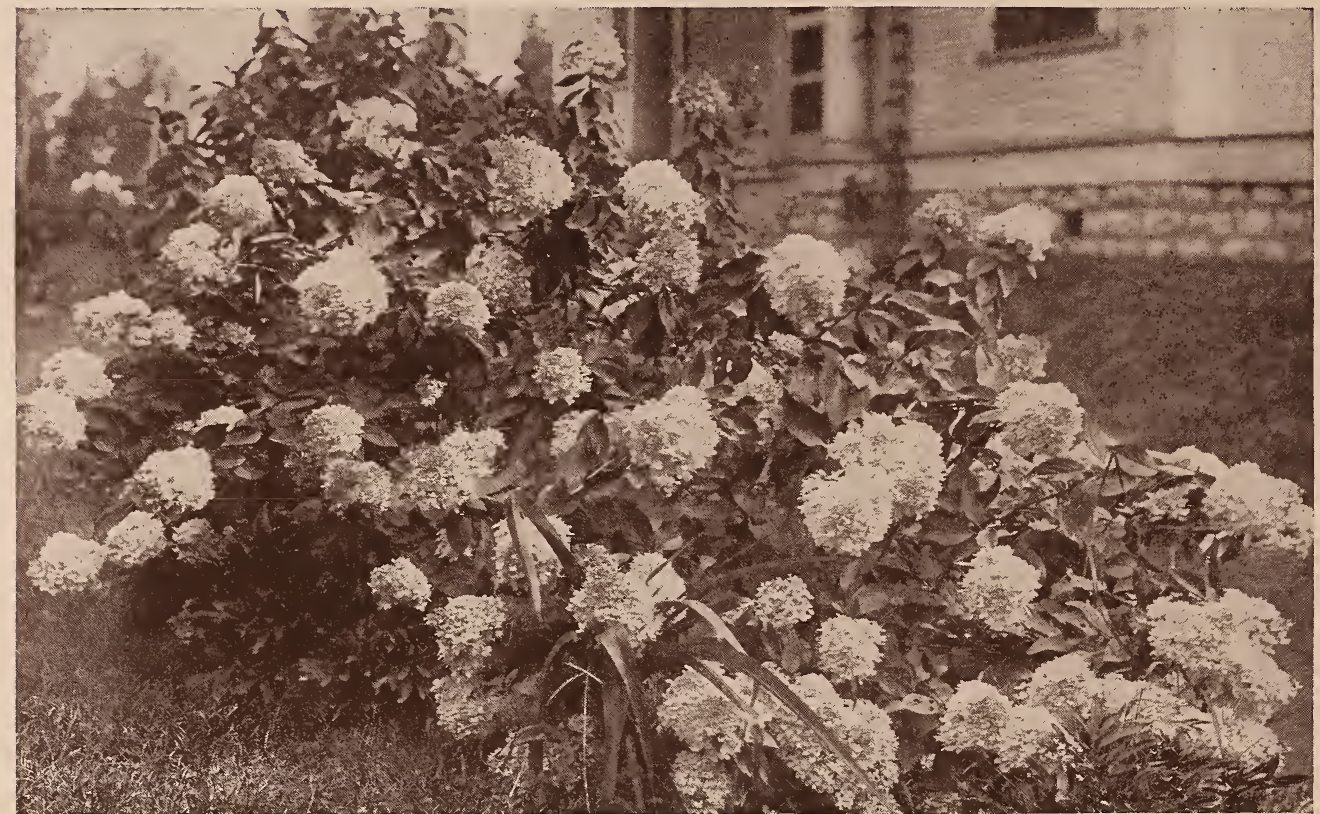

Hydrangea Grandiflora

\section{F. Intermedia-Border Forsythia.}

One of the most floriferous, with slender, arching branches and dark green leaves. It blooms so early that it is frequently covered with its bright golden flowers when the ground is covered with snow. This shrub is one of the very first promises of the bright and beautiful spring to come.

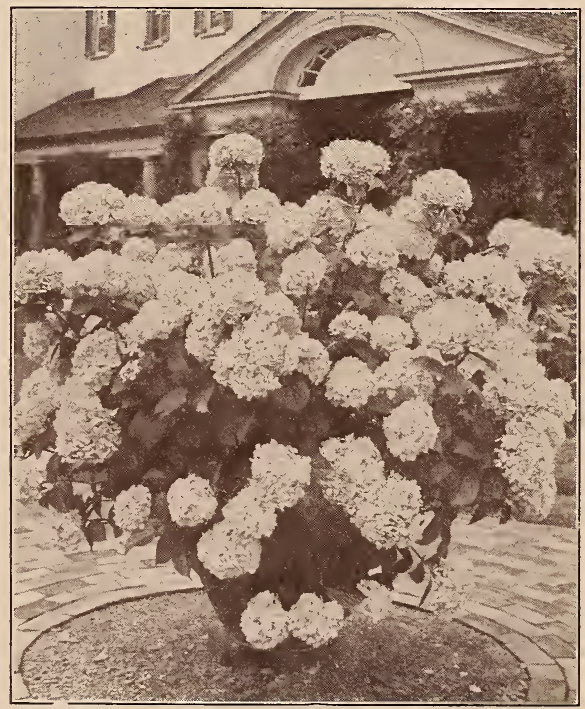

Hydrangea Aborescens

\section{F. Suspensa.}

Handsome, erect lorm, very vigorous grower and very prolific bloomer. Flowers golden and continue a long time. A very conspicuous object in shrubbery.

\section{HAMAMELIS Virginica-Witch Hazel.}

Valuable because of its fringe-like yellow flowers which open so late in the fall when there are few other blossoms outdoors anywhere. Grows 10 to 15 feet tall. Likes a moist, sandy or peaty soil and partial shade.

$\begin{array}{rrrr} & \text { Each } & \text { Per } 10 & \text { Per } 100 \\ 3 \text { to } 4 \text { ft......... } \$ 1.00 & \$ 8.00 & \$ 70.00 \\ 4 \text { to } 5 \text { ft......... } 1.25 & 10.00 & 90.00\end{array}$

\section{HYDRANGEA Aborescens Grandiflora.}

This superb new Hydrangea is absolutely hardy and moreover, of easy culture, and is an exceedingly easy bloomer. As high as 125 blossoms, with an average of six inches in diameter, have been found on a single plant at one time. Color is pure white, which is usually retained for four or five weeks. Blooms first season. Should be cut back severely in the spring.

$\begin{array}{rrrr} & \text { Each } & \text { Per } 10 & \text { Per } 100 \\ 2 \text { to } 3 \mathrm{ft} . \ldots \ldots \ldots \ldots \$ 1.00 & \$ 9.00 & \$ 80.00 \\ 3 \text { to } 4 \mathrm{ft} . \ldots \ldots \ldots .1 .10 & 10.00 & 90.00\end{array}$

\section{H. Paniculata Grandiflora.}

Familiar to almost everyone as the most conspicuous shrub in any collection in August and September. Its massive white flowers bend the branches with their weight, with the color changing finally to pink and a bronzy green.

Each Per 10 Per 100

2 to $3 \mathrm{ft} . \ldots \ldots \ldots \ldots 1.00 \quad \$ 9.00 \quad \$ 80.00$

3 to $4 \mathrm{ft} \ldots \ldots \ldots \ldots .1 .10 \quad 10.00 \quad 90.00$ 


\section{Plants of Permanence}

\section{H. Paniculata Grandiflora-(Tree Form).}

Same as the above description, except that it is the tree form, rather than the shrub. Often makes a strong, vigorous bush from six to eight feet high. Imported from Holland. Free flowering.

Each Per 10

3 to $4 \mathrm{ft} . \ldots \ldots \ldots \ldots \ldots \ldots \ldots 1.50 \quad \$ 12.50$

4 to $5 \mathrm{ft} . \ldots \ldots \ldots \ldots \ldots \ldots \ldots . \ldots \ldots$

\section{H. Quercifolia-Oak Leaved Hydrangea.}

Each Per 10

2 to $3 \mathrm{ft} . \ldots \ldots \ldots \ldots \ldots \ldots \ldots \$ 1.00 \$ 9.00$

3 to $4 \mathrm{ft} \ldots \ldots \ldots \ldots \ldots \ldots \ldots \ldots \ldots 1.25 \quad 10.00$

ILEX Verticillata-Black Alder or Winterberry.

A very ornamental shrub with upright branches and light green foliage. Its bright scarlet berries remain on the branches until mid-winter.

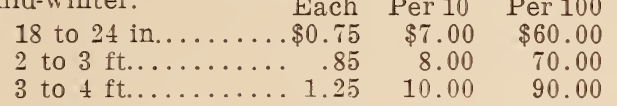

KERRIA Japonica. Fl. Pl. Corchorus.

A slender, green branched shrub, with globular yellow flowers from July to October.

$$
\begin{aligned}
& 18 \text { to } 24 \text { in........ } \$ 0.75 \quad \begin{array}{rr}
\text { Per } 10 & \text { Per } 100 \\
\$ 6.50 & \$ 60.00
\end{array} \\
& 2 \text { to } 3 \mathrm{ft} . \ldots \ldots \ldots \ldots .90 \quad 8.00 \quad 75.00
\end{aligned}
$$

\section{LILAC-(See Syringa).}

\section{LIGUSTRUM Amurense-Amoor River Privet -North.}

The Chinese variety, hardier than the others, growing eight to twelve feet high, with dark green leaves which persist through the winter. Evergreen in the south. Bears erect and handsome white flowers in June, which are followed by black berries. It is absolutely the best of all plants for hedge purposes and one of the best for shrubbery planting. Hardy in all climates. Each Per 10 Per 100

3 to 4 ft.......... $40.35 \quad \$ 3.00 \quad \$ 25.00$
4 to 5 ft......... $45 \quad 4.00 \quad 35.00$

5 to $6 \mathrm{ft}$, heavy.... $.55 \quad 5.00 \quad 40.00$

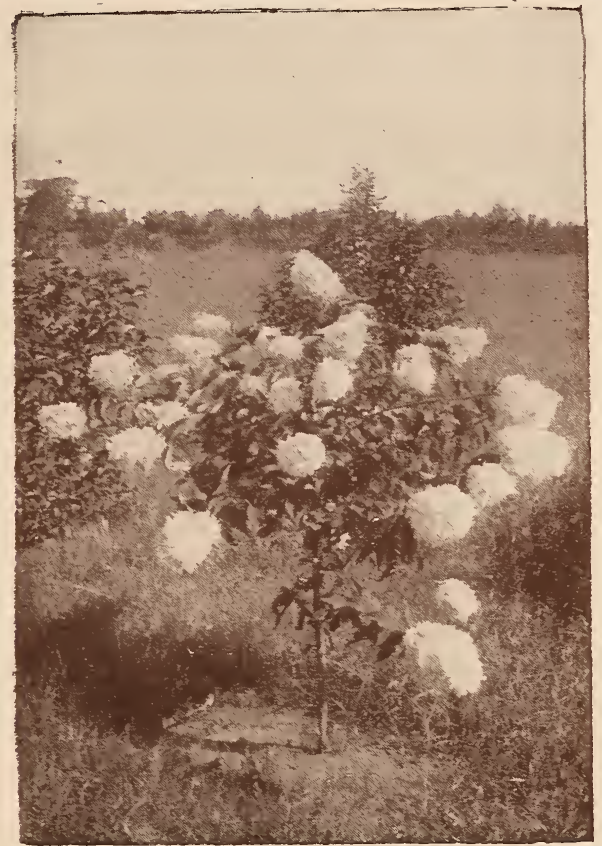

Hydrangea-Tree Form

\section{Ibota.}

A fine and hardy border shrub, of spreading habit, with curving branches and leaves of grayish green. Pure white flowers in June, followed by bluish-black seeds. Among the hardiest of Privet varieties. Makes an excellent hedge and a very ornamental shrub.

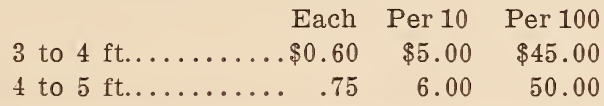

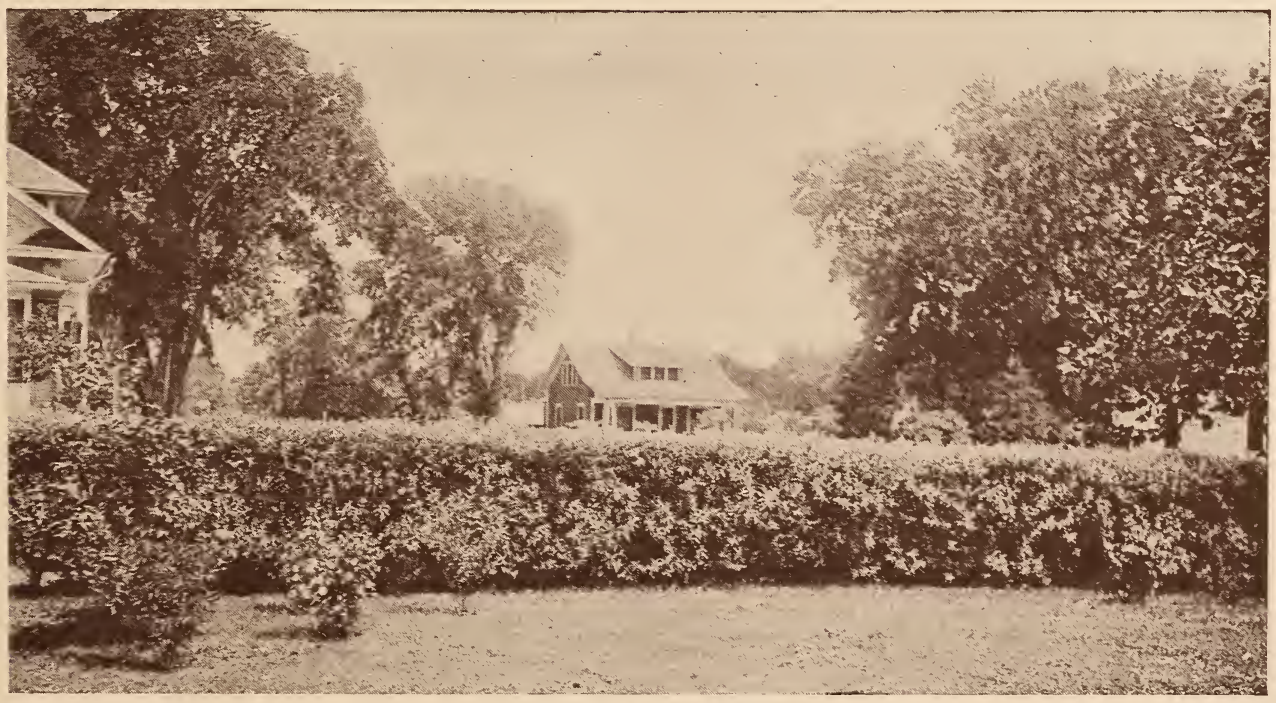

Privet as a Hedge 


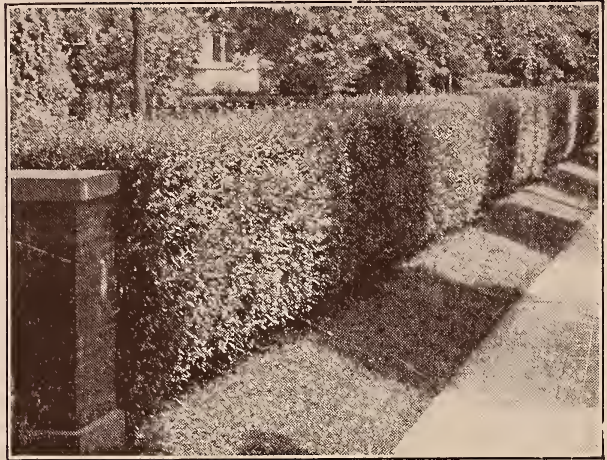

California Privet

\section{Ibota Regalianum-Regal's Privet.}

The horizontal, sometimes drooping branches, of this bush are distinctly beautiful. Has longer and narrower leaves than the other varieties. This is one of the best of the Privets. Absolutely hardy and graceful. Berries remain on all winter and are very attractive.

Each Per 10 Per 100

24 to 30 in........\$0.60 \$5.50 $\$ 50.00$

30 to 36 in......... $.75 \quad 6.50 \quad 60.00$

36 to 42 in........ $\quad .90 \quad 8.00 \quad 70.00$

42 to 48 in........ $1.00 \quad 9.00 \quad 80.00$

\section{Ovalifolium-California Privet.}

A species of unusual beauty that has become the most popular of all hedge plants. Its shining leaves give it value for porch and terrace decoration when grown in standard form. Can be sheared to any desirable shape.

$\begin{array}{rrrr} & \text { Each } & \text { Per } 10 & \text { Per } 100 \\ 12 \text { to } 18 \mathrm{in} . \ldots \ldots \ldots \ldots \$ 0.12 & \$ 0.80 & \$ 5.00 \\ 18 \text { to } 24 \mathrm{in} . \ldots \ldots \ldots & .14 & 1.00 & 7.00 \\ 2 \text { to } 3 \mathrm{ft} . \ldots \ldots \ldots \ldots & .15 & 1.25 & 8.00 \\ 3 \text { to } 4 \mathrm{ft} . \text { heavy.... } & .25 & 1.75 & 9.00 \\ 4 \text { to } 5 \mathrm{ft} . \text { heavy.... } & .30 & 2.00 & 15.00\end{array}$

\section{Ovalifolium Aureum-Golden Privet.}

Same habit as California Privet but not as strong a grower. Foliage golden.

$$
\begin{array}{rrr}
\text { Fach } & \text { Per } 10 & \text { Per } 100 \\
1 \text { year ........\$ } \$ 0.40 & \$ 3.50 & \$ 30.00
\end{array}
$$

\section{Vulgaris-European Privet.}

A good hedge plant with narrow, dull green foliage and quite showy flowers of white. Blooms June and July. Clusters of black berries follow the bloom which adhere to the shrub all winter.

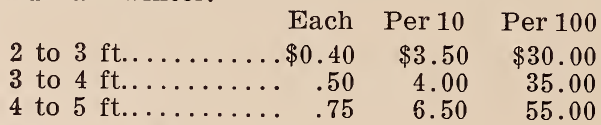

Page Thirty-six

\section{LONICERA Fragrantissima-Fragrant}

Honeysuckle.

A spreading shrub with deep green foliage and very fragrant small flowers, which appear before the leaves. Foliage almost evergreen; most desirable. Each Per 10 Per 100

3 to $4 \mathrm{ft} . \ldots \ldots \ldots \ldots \$ 0.80 \quad \$ 7.00 \quad \$ 60.00$

4 to $5 \mathrm{ft} . \ldots \ldots \ldots \ldots$
$.90 \quad 8.00 \quad 70.00$

L. Bella Albida-White.

White flowers; showy red fruit in great profusion. Very fine. Each Per 10 Per 100

4 to $5 \mathrm{ft} . \ldots \ldots \ldots \ldots \$ 0.90 \quad \$ 8.00 \quad \$ 70.00$

5 to $6 \mathrm{ft} . \ldots \ldots \ldots \ldots 1.00 \quad 9.00 \quad \ldots \ldots$

L. Bella Chrysantha-Pink.

Shrub to 12 feet. Flowers in May and June. Yellowish white flowers, changing to yellow. Fruits in August and September.

4 to 5 ft. ...... Each $\begin{array}{rrr}\text { Per } 10 & \text { Per } 100 \\ \$ 8.00 & \$ 70.00\end{array}$

L. Morrowi.

A fine variety from Japan. Valuable for its handsome red fruit. Vigorous grower and fine for heavy shrub planting.

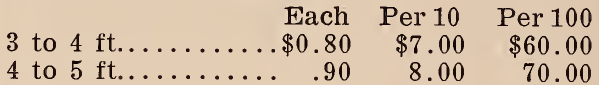

\section{Ruprechtiana.}

Particularly for its yellowish-white flowers in June, followed by showy red fruit in the autumn. Vigorous grower; fine for heavy shrub planting. Each Per 10 Per 100 4 to 5 ft........\$0.90 $\$ 8.00 \quad \$ 70.00$

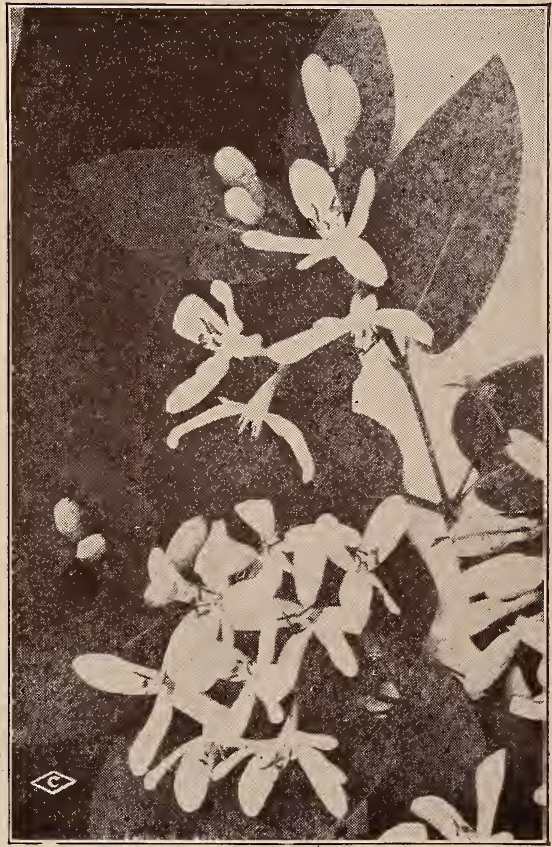

Bush Honeysuckle 


\section{Tartarica-Red Tartarian Honeysuckle.}

Similar to the White Tartarian, but with deep, rose-pink flowers in early summer.

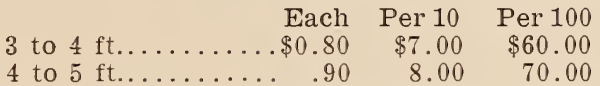

\section{Tartarica Alba-White Tartarian Honey- suckle.}

Forms a high bush, with creamy-white, fragrant flowers that bloom in May and June.

\begin{tabular}{|c|c|c|}
\hline & Per 10 & $\mathrm{Pe}$ \\
\hline & $\$ 8.00$ & $\$$ \\
\hline & 9.00 & \\
\hline
\end{tabular}

\section{Tartarica Grandiflora Rosea.}

A beautiful shrub, very vigorous, and producing large, bright red flowers striped with white, in June.

\begin{tabular}{|c|c|c|c|}
\hline . & Each & Per 10 & Per 100 \\
\hline to $4 \mathrm{ft}$. &.$\$ 0.80$ & $\$ 7.00$ & $\$ 60.00$ \\
\hline to $5 \mathrm{ft}$. & .90 & 8.00 & 70.00 \\
\hline to $6 \mathrm{ft}$ & 1.00 & 9.00 & \\
\hline
\end{tabular}

L. Xylosteum-Fly Honeysuckle.

$\begin{array}{rrrr}\text { Each } & \text { Per } 10 & \text { Per } 100 \\ 3 \text { to } 4 \mathrm{ft} . \ldots . . . . \$ 0.90 & \$ 8.00 & \$ 70.00\end{array}$

PHILADELPHUS Coronarius-Mock Orange or Sweet Syringa.

A well known shrub, with pure white, sweetly scented flowers. One of the first to bloom.

\begin{tabular}{|c|c|c|c|}
\hline & Each & Per 10 & Per 100 \\
\hline 4 to $5 \mathrm{ft}$. &.$\$ 0$ & $\$ 8.00$ & $\$ 70.00$ \\
\hline 5 to $6 \mathrm{ft}$. & 1.00 & 9.00 & 80.00 \\
\hline to $8 \mathrm{ft}$. & 1.25 & 10.00 & \\
\hline
\end{tabular}

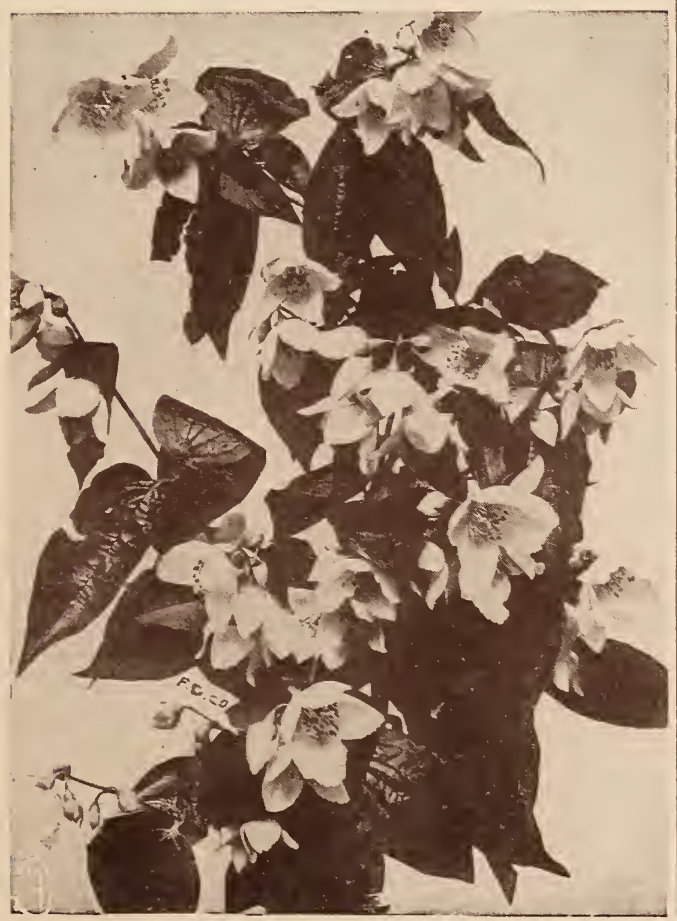

Sweet Syringa or Mock Orange

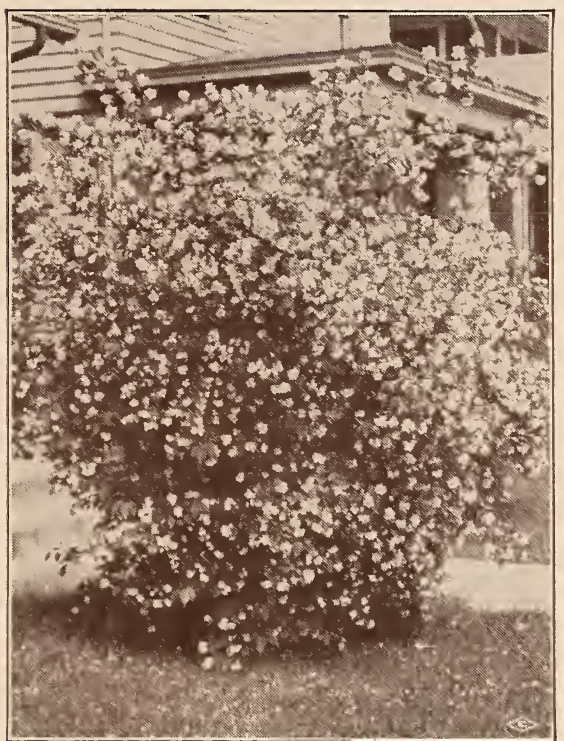

Philadelphus Lemoinei

P. Coronarius Nana Aurea-Golden Syringa.

A compact dwarf growing shrub, with very brilliant yellow foliage in the spring. Holds its color well. Good for contrast with dark leaved shrubs. Flowers white, in May and June.

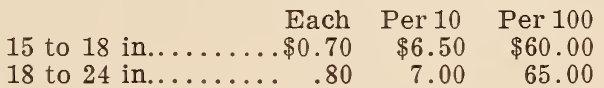

P. Gordonianus-Gordon's Syringa.

Best late bloomer.

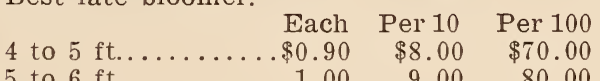

\section{P. Grandiflorus.}

Has very large flowers, slightly fragrant, branches somewhat straggling.

\begin{tabular}{|c|c|c|}
\hline Each & Per 10 & Per 100 \\
\hline to & $\$ 8$. & 0 \\
\hline 6 & 9.00 & 80.0 \\
\hline
\end{tabular}

\section{P. Laxus-Large Flowering Syringa.}

Each Per 10 Per 100

4 to $5 \mathrm{ft} \ldots \ldots \ldots \ldots . . . . . .90 \quad \$ 8.00 \quad \$ 70.00$

5 to $6 \mathrm{ft} \ldots \ldots \ldots \ldots 1.00 \quad 9.00 \quad 80.00$

\section{P. Lemoinei Boquet Blanc.}

A charming variety of dwarf habit, with very large fragrant flowers, produced in great abundance.

\begin{tabular}{|c|c|c|c|}
\hline & Each & Per 10 & Per 100 \\
\hline to & $\$ 0.8$ & $\$ 7.00$ & $\$ 65.00$ \\
\hline to 4 & .90 & 8.00 & 70.00 \\
\hline
\end{tabular}

P. Lemoinei Erectus.

Very erect in growth. Leaves small and narrow. Branches slender and covered with white snowy flowers in May and June.

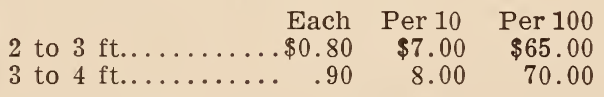




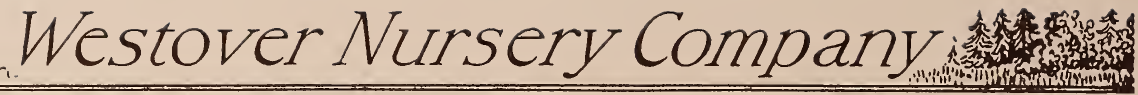

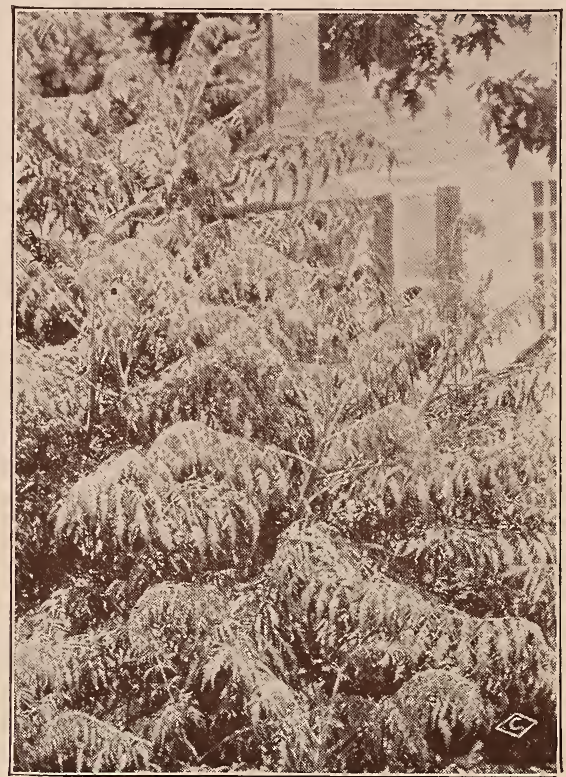

Cut-Leaved Sumac

P. Nivalis-Large Flowering Sweet Syringa.

The stamens of this variety are cream colored, thus rendering the whole flower very white.

Each Per 10 Per 100

4 to 5 ft.......... \$0.90 $\$ 8.00 \quad \$ 70.00$

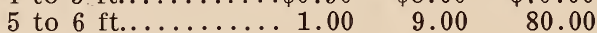

P. Dianthusflorus Pl.

Of dwarf habit with semi-double flowers.

Each Per 10 Per 100

3 to 4 ft..........\$0.80 $\$ 7.00 \quad \$ 65.00$

4 to $5 \mathrm{ft} . \ldots \ldots \ldots \ldots . . .21 .00 \quad 9.00 \quad 80.00$

P. Virginal-Large Flowering Syringa.

Neat habit - the finest of this family. Blooms two inches in diameter. May and June.

Each Per 10

2 to $3 \mathrm{ft} . \ldots \ldots \ldots \ldots \ldots \ldots \ldots 1.00 \$ 9.00$

3 to $4 \mathrm{ft} . \ldots \ldots \ldots \ldots \ldots \ldots . . .61 .50 \quad 12.50$

PHYSOCARPUS Opulifolia Aurea-Ninebark, or Golden Spirea.

Tall growing. The leaves are bright yellow in spring, gradually changing to golden brown in the fall. Flowers double, white.
4 to $5 \mathrm{ft} \ldots \ldots \ldots \ldots \$ 0.80$
Per 10
$80 \$ 7.00$
Per 100
5 to $6 \mathrm{ft} \ldots \ldots \ldots \ldots .90$
8.00
$\$ 60.00$
6 to $8 \mathrm{ft} \ldots \ldots \ldots \ldots 1.00$
9.00
80.00

\section{RHAMNUS Catharticus-Buckthorn.}

A fine, robust, hardy shrub, of European origin, with dark green foliage, white flowers and small black fruit.

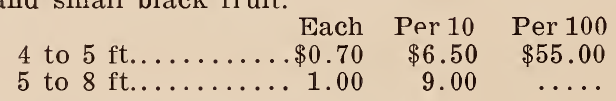

R. Caroliniana-Indian Cherry.

A fine shrub with dark green foliage. Fruit red, changing to black.

4 to $5 \mathrm{ft} \ldots \ldots \ldots \ldots \ldots \ldots 1.00$

5 to $6 \mathrm{ft} \ldots \ldots \ldots \ldots \ldots \ldots \ldots 1.10$

Per 10

$\$ 9.00$

10.00

\section{R. Frangula-Glossy Buckthorn.}

Dense shrub with beautiful tinted foliage in fall with red and black berries in September.

Each Per 10

5 to $6 \mathrm{ft} . \ldots \ldots \ldots \ldots \ldots \ldots \ldots \$ 1.00 \$ 9.00$

6 to $8 \mathrm{ft} \ldots \ldots \ldots \ldots \ldots \ldots \ldots \ldots 1.10 \ldots \ldots$

\section{RHODOTYPUS Kerroides-White Kerria.}

A very ornamental shrub of medium size, with handsome foliage and large, single white flowers in the latter part of May succeeded by numerous fruits. Each Per 10 Per 100

2 to $3 \mathrm{ft} . \ldots \ldots \ldots \ldots \$ 0.80 \quad \$ 7.50 \quad \$ 70.00$

3 to $4 \mathrm{ft. \ldots \ldots \ldots \ldots ..90} \quad .90 \quad 8.00 \quad 75.00$

\section{RHUS Aromatica-Fragrant Sumac.}

A native variety, exhaling a strong odor. Flowers greenish-white; leaves lobed.

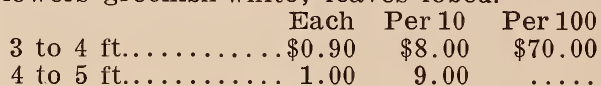

\section{R. Coppalina-Shining Sumac.}

Beautiful shining green foliage, changing to rich crimson in autumn. Greenish yellow flowers in August. Each Per 10 Per 100 3 to $4 \mathrm{ft} . \ldots \ldots \ldots \ldots \$ 0.75 \quad \$ 6.50 \quad \$ 60.00$

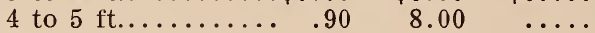

\section{R. Cotinus-Purple Fringe.}

Comes from the south of Europe and is noted for the curious fringe or hair-like flowers that cover the whole surface of the plant in midsummer. It grows from 10 to 12 feet high and spreads so as to require considerable space.

Each Per 10

2 to $3 \mathrm{ft} . \ldots \ldots \ldots \ldots \ldots \ldots \ldots 1.00 \$ 9.00$

3 to $4 \mathrm{ft} . \ldots \ldots \ldots \ldots \ldots \ldots \ldots 1.25 \quad 10.00$

R. Glabra-Smooth Sumac.

Very effective in autumn with its crimson seeds and light colored foliage.

5 to $6 \mathrm{ft} \ldots \ldots \ldots \ldots \ldots \ldots \ldots . \$ 0.90 \quad \begin{aligned} & \text { Each } \\ & \text { Per } 10\end{aligned}$

6 to $8 \mathrm{ft} . \ldots \ldots \ldots \ldots \ldots \ldots 1.00 \quad 9.00$

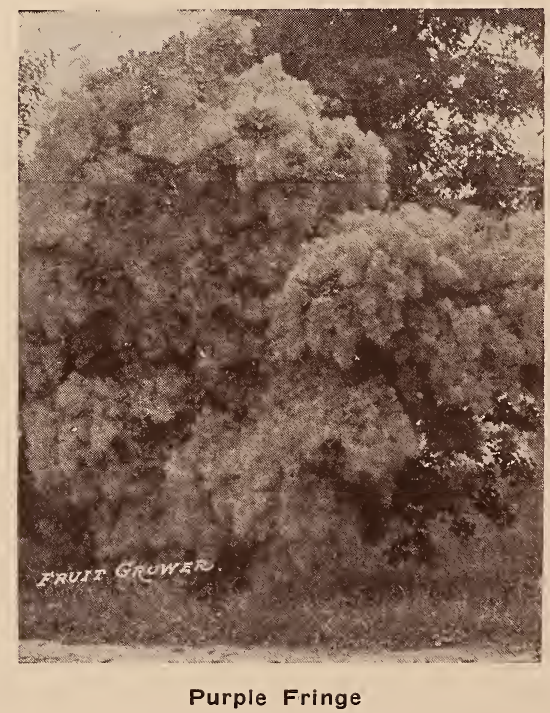




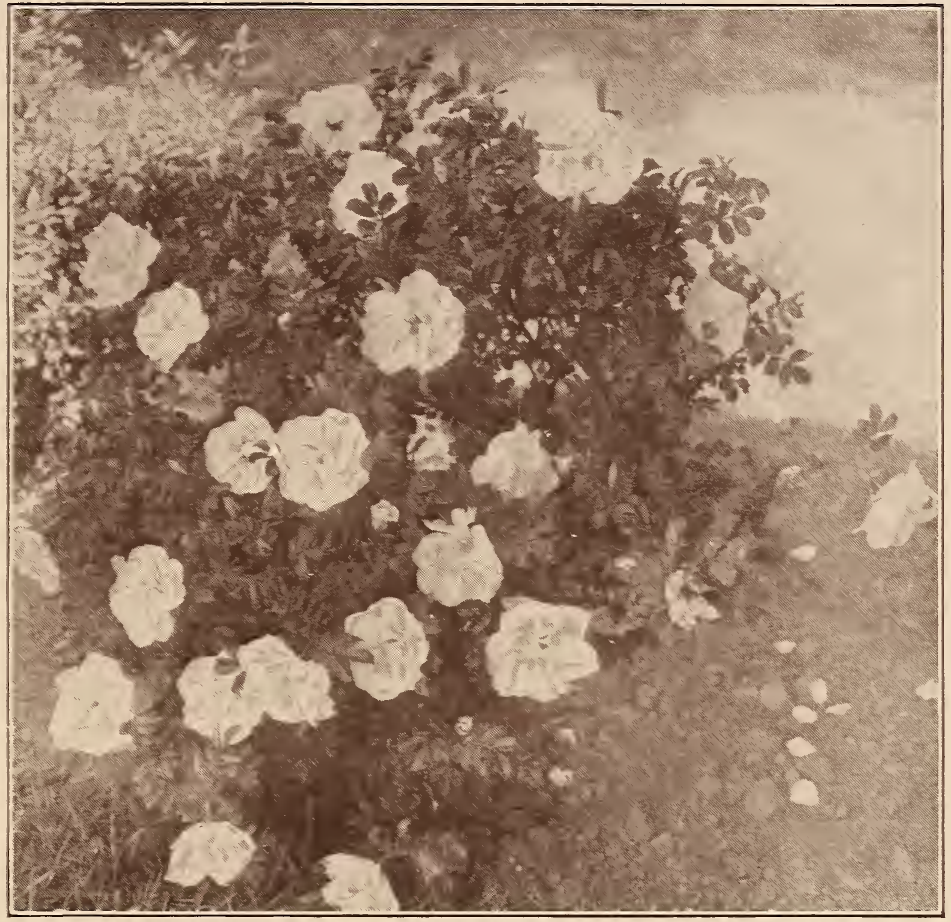

Japanese Rose

\section{R. Typhina Laciniata-Cut-Leaved Sumac.}

A very striking plant of moderate size with deeply cut leaves which resemble fern leaves. Dark green above and glaucous below, turning to a rich red in autumn.

\begin{tabular}{|c|c|c|}
\hline Each & Per 10 & Per 1 \\
\hline to & 58.00 & $\$ 7$ \\
\hline $6 \mathrm{f}$ & 9.00 & 8 \\
\hline
\end{tabular}

\section{RIBES Aureum-Yellow Flowering Currant.}

A native species with glabrous shining leaves and yellow flowers.

$\begin{array}{rrrr} & \text { Each } & \text { Per } 10 & \text { Per } 100 \\ 3 \text { to } 4 \mathrm{ft} . \ldots \ldots \ldots \ldots & \$ 0.90 & \$ 8.00 & \$ 70.00 \\ 4 \text { to } 5 \mathrm{ft} \ldots \ldots \ldots & 1.00 & 9.00 & 80.00\end{array}$

\section{ROSA Blanda-Meadow Rose.}

Pink bloom; erect habit. Red bark. Blooms in May and June.
2 year
Each
Per 10
$\$ 7.00$

\section{R. Carolina-Swamp Rose.}

Hardy, shrubby, with pink flowers.

2 year $\ldots \ldots \ldots \ldots \ldots \ldots \ldots 0.75$

Per 10

$\$ 7.00$

\section{R. Hugonis.}

New yellow Chinese Briar. Has clean healthy foliage of the Briar type. The flowers range from deep gold to canary.

Each Per 10

2 year ..............\$1.25 \$10.00

\section{R. Lucida-Dwarf Wild Rose.}

The familiar wild rose. Flowers pink in June, covered with red fruit in the fall.

2 vear $\ldots \ldots \ldots \ldots \ldots \ldots \ldots . .75 \quad \begin{aligned} & \text { Each } \\ & \$ 7.00\end{aligned}$

\section{R. Persian Yellow.}

This is the old fashioned yellow rose which is very hardy and covered with yellow flowers in the spring.
2 year old ..............\$0.90

\section{R. Rubrifolia-Red Leaved Rose.}

Leaves are blue-green, tinged with purplishred. Fruit scarlet. Attractive in early winter. Very hardy and valuable for color effect in landscape.

2 year $\ldots \ldots \ldots \ldots \ldots \ldots \ldots \$ 0.75 \quad \begin{aligned} & \text { Each } \text { Per } 10 \\ & \$ 7.00\end{aligned}$

\section{R. Rubiginosa-Sweet Briar.}

Flowers single, pink and very fragrant. Valuable in landscape work. Grows to a height of six feet.

2 year $\ldots \ldots \ldots \ldots \ldots \ldots \ldots .80 \quad \begin{aligned} & \text { Each } \\ & \text { Per } 10 \\ & \$ 7.50\end{aligned}$

\section{R. Rugosa-Japanese Rose.}

The foliage is lustrous dark green. Flowers are borne in clusters which are succeeded by persistent fruits which carry their usefulness into winter. Valuable for landscape work.
2 year, No. $1 \ldots \ldots \$ 0.90$
Per 10
Per 100
$\$ 70.00$ 


\section{Westover Nursery Company}

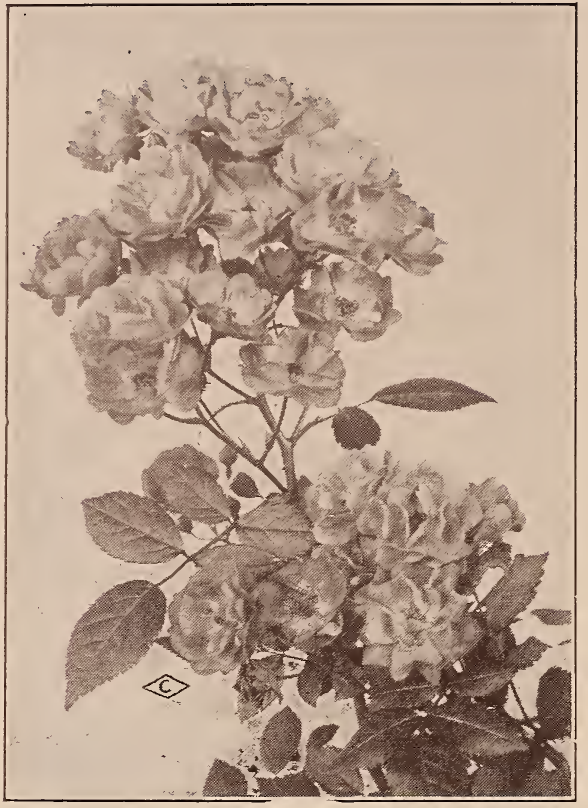

R. Rugosa Grootendorst

\section{R. Rugosa Century.}

A very beautiful flesh pink with light red center.

$$
\text { Each Per } 10 \text { Per } 100
$$

R. Rugosa Conrad F. Meyer.

A Japanese variety of a lovely silvery rose, full double with a fragrance that is wonderful. A rose of many virtues and surpassing beauty. Blooms freely all season.

$$
\begin{array}{rrr}
\text { Each } & \text { Per } 10 & \text { Per } 100 \\
\$ \text { year, No. 1.....\$1.00 } & \$ 9.00 & \$ \ldots \ldots
\end{array}
$$

\section{R. Rugosa F. J. Grootendorst-Red Baby} Rambler Flowers.

This rose is the result of crossing a briar rose with the dwarf rambler. A very hardy rose. Grows vigorously. Flowers are borne in clusters and each individual rose stands out full, clean and distinctive. Color is a decided deep red. Blooms constantly from early summer to late winter.

Each Per 10

4 year, No. $1 \ldots \ldots \ldots \ldots \ldots \ldots \$ 1.25 \$ 10.00$

\section{R. Rugosa Str. Thomas Lipton.}

Bears double, pure white flowers on long stems in early summer. Very vigorous grower. Each Per 10 Per 100

2 year, No. 1.....\$1.00 $\$ 9.00 \quad \$ \ldots \ldots$

\section{R. Setigera-Prairie Rose.}

Has long, slender, recurving branches. Height six feet. Blooms in profusion. Valuable in landscape work for massed plantings.

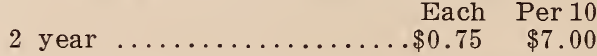

\section{RUBUS Odoratus_Flowering Raspberry.}

A strong growing plant from three to six feet high. Leaves are very large and flowers measure about one-half inch in diameter. Flowers are rose-purple. Valuable for landscape work and effects.
2 to $3 \mathrm{ft}$
Each Per 10

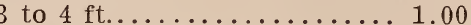
$\$ 8.00$
9.00

\section{SAMBUCUS Canadensis-Common American}

\section{Elder.}

Broad panicles of white flowers in June; reddish-purple berries in autumn. A well known native shrub.

$\begin{array}{rrrr}4 & \text { Each } & \text { Per } 10 & \text { Per } 100 \\ 5 \text { to } 5 \text { ft. } 6 \ldots \ldots \ldots . \$ 0.90 & \$ 8.00 & \$ 70.00 \\ 6 \text { to } 8 \mathrm{ft} . \ldots \ldots \ldots \ldots & 1.00 & 9.00 & 80.00 \\ & \end{array}$

\section{S. Nigra Laciniata-Black Berried Cut-Leaved} Elder.

A very striking plant, of moderate size, with deeply cut leaves, resembling fern leaves. Dark green above and glaucous below, and turning to a rich red in autumn.

$\begin{array}{rrrr}4 & \text { Each } & \text { Per } 10 & \text { Per } 100 \\ 5 \text { to } 5 \text { ft......... } 6 \text { ft......... } 1.00 & \$ 8.00 & \$ 70.00 \\ & 9.00 & 80.00\end{array}$

S. Nigra Aurea-Golden Elder.

A handsome variety with golden-yellow foliage. A valuable plant for enlivening shrubberies.

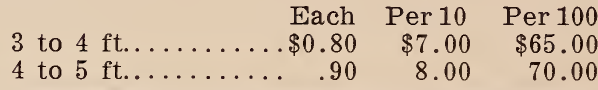

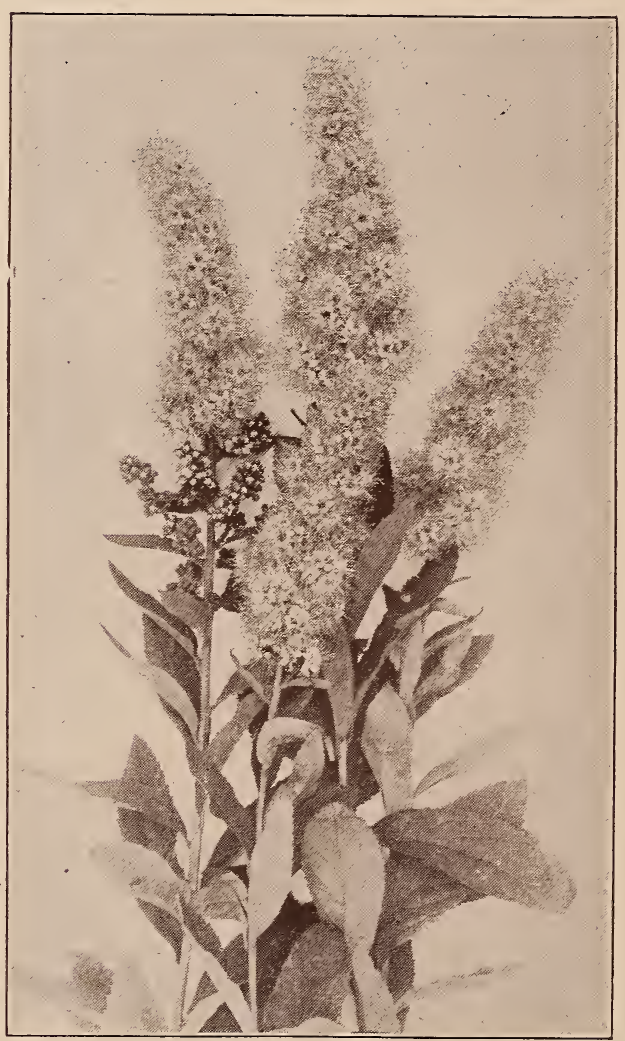

Spirea Billardi

Page Forty 


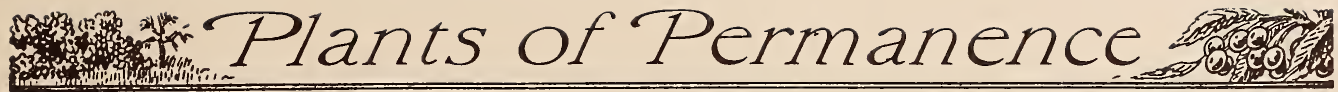

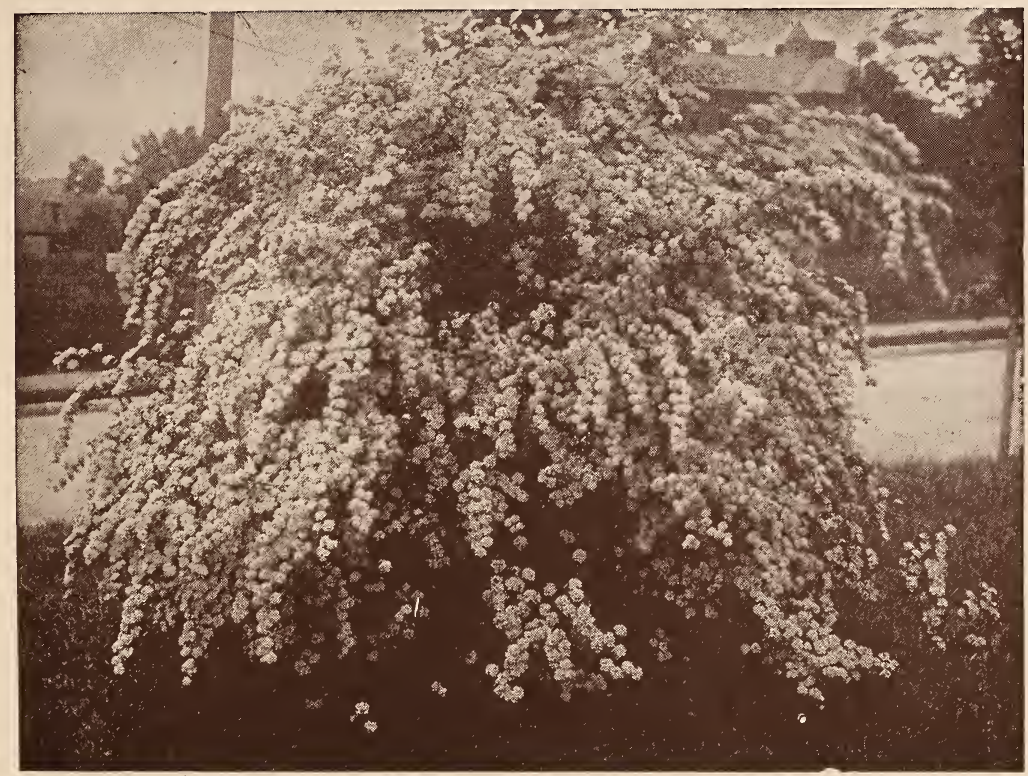

Spirea Van Houtte

\section{SPIREA Billardi-Meadow Sweet.}

A narrow dense shrub, six feet high, tall bright pink pikes, with branches a showy mass of clear white flowers in early May.

$\begin{array}{rrrrr}3 \text { to } 4 \mathrm{ft} . \ldots \ldots \ldots \ldots . & \text { Each } & \text { Per } 10 & \text { Per } 100 \\ 4 \text { to } 5 \mathrm{ft} . \ldots \ldots \ldots \ldots & \$ 6.50 & \$ 60.00 \\ & & .80 & 7.50 & 60.00\end{array}$

\section{S. Billardi Alba.}

2 to $3 \mathrm{ft} . \ldots \ldots \ldots \ldots \$ 0.65 \quad \$ 6.00 \quad \$ 55.00$

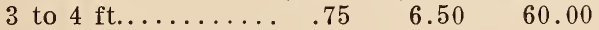

\section{S. Bumaldi.}

Low growing shrub with flat heads of light pink flowers.

$\begin{array}{rrr}\text { Each } & \text { Per } 10 & \text { Per } 100 \\ \$ 0.75 & \$ 6.50 & \$ 60.00 \\ . \quad .80 & 7.50 & 65.00\end{array}$

18 to 24 in.......\$0.75 $\$ 6.50 \quad \$ 60.00$

S. Bumaldi Anthony Waterer.

Low compact growing shrub. A new form of better habit than the type, with large corymbs of rosy crimson.

Each Per 10 Per 100

18 to 24 in.......\$0.75 $\$ 6.50 \quad \$ 60.00$

24 to 30 in....... $.80 \quad 7.50 \quad 65.00$

\section{S. Callosa Alba.}

Of dwarf, compact growth, with upright branches and bluish-green foliage; crowded with large, flat clusters of white flowers nearly all summer.

Each Per 10 Per 100

18 to 24 in.......\$0.75 $\$ 6.50 \quad \$ 60.00$

24 to 30 in....... $.80 \quad 7.50 \quad 65.00$

\section{S. Callosa Rosea.}

Deep rose-red flowers in close clusters, blooming nearly all summer.

\begin{tabular}{|c|c|c|}
\hline 36 in & Each & Per 10 \\
\hline to 42 & ח & \\
\hline
\end{tabular}

S. Douglasi.

Upright in growth, with reddish-brown branches and narrow, oblong leaves. Bears spikes of beautiful, deep rose-colored flowers in July and August. Each Per 10 Per 100

2 to $3 \mathrm{ft} . \ldots \ldots \ldots . \$ 0.65 \quad \$ 6.00 \quad \$ 55.00$

3 to $4 \mathrm{ft} \ldots \ldots \ldots \ldots .60 .75 \quad 6.50 \quad 60.00$

\section{S. Froebeli.}

A taller form of Spirea than the Anthony Waterer, with broader leaves, having bright crimson flowers. Each Per 10 Per 100 18 to 24 in.......\$0.65 $\$ 5.50 \quad \$ 50.00$ 24 to 30 in........... $.70 \quad 6.00 \quad 55.00$ 30 to 36 in......... $.80 \quad 7.00 \quad 60.00$

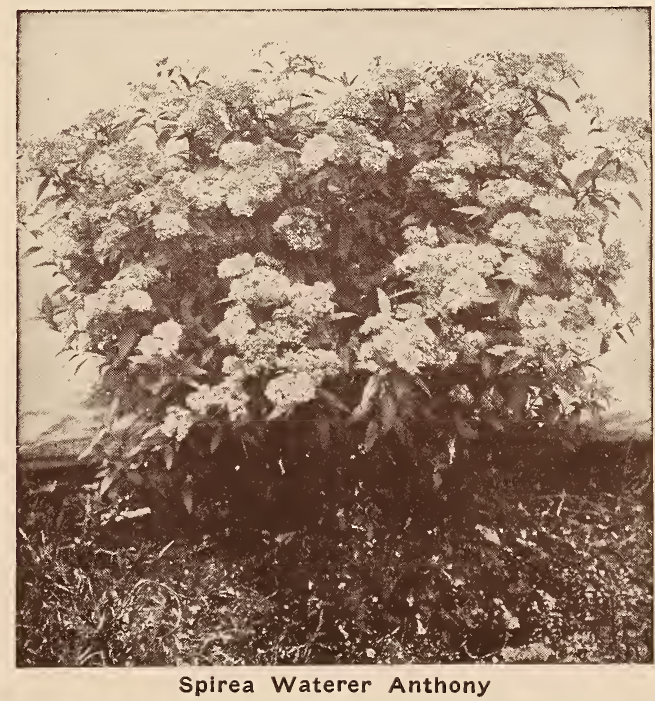

Page Forty-one 


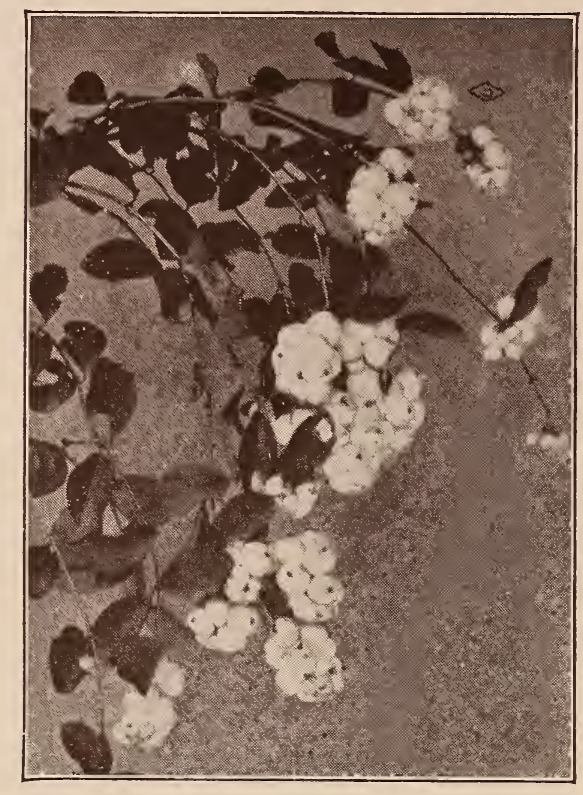

Snowberry

S. Opulifolia-(See Rhysocarpus).

\section{S. Prunifolia-Bridal Wreath.}

Among the earliest of the double Spireas to bloom. Very graceful and plume-like in effect, branches being covered with small, double white flowers, sweeping outward in gentle curves.

\begin{tabular}{|c|c|c|c|}
\hline & $\mathrm{E}$ & Per 10 & Per \\
\hline t &.$\$ 0$. & $\$ 6.50$ & 60 \\
\hline , & .8 & 7.50 & 0. \\
\hline
\end{tabular}

\section{S. Reevesiana, Fl. Pl.}

Tall and graceful, five to eight feet high, with dark, bluish-green, lance-like foliage and large, pure double-white flowers in May and June.

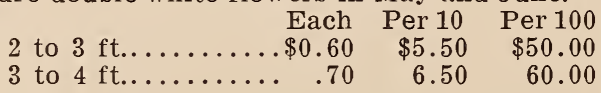

\section{S. Thunbergii.}

Distinct and most attractive at all seasons, with feathery masses of pure white flowers in early spring. In autumn, its narrow leaves change to a bright orange and red.

\begin{tabular}{|c|c|c|}
\hline Each & Per 10 & Per 100 \\
\hline$\$ 0.75$ & $\$ 7.00$ & $\$ 60.00$ \\
\hline to 42 in.. & 8.00 & 70.00 \\
\hline . 1.00 & 9.00 & 80.00 \\
\hline
\end{tabular}

\section{S. Van Houtte-Bridal Wreath.}

One of the most charming and beautiful of the Spireas. Has white flowers in clusters about an inch in diameter. Astonishingly profuse in bloom and is remarkably vigorous and hardy. Fine for planting singly or in groups, or as banking against buildings.

$\begin{array}{rrrr}3 \text { Each } & \text { Per } 10 & \text { Per } 100 \\ 4 \text { to } 4 \mathrm{ft} . \ldots \ldots \ldots \ldots & \$ 0.70 & \$ 6.00 & \$ 50.00 \\ \text { to } 5 \text { ft......... } & .80 & 7.50 & 70.00\end{array}$

SYMPHORICARPUS Racemosus-Snowberry.

A well known shrub with small pink flowers and large white berries which remain on the plant throughout part of the winter.

$$
\begin{array}{rrrr}
2 & \text { Each } & \text { Per } 10 & \text { Per } 100 \\
3 \text { to } 3 \mathrm{ft} . \ldots \ldots \ldots \ldots & \$ \ldots .70 & \$ 6.00 & \$ 50.00 \\
&
\end{array}
$$

\section{S. Vulgaris-Buckbrush or Coral Berry.}

Similar to the Snowberry, except that the berries ar smaller and red in color. The habit is of slightly drooping nature and of vigorous growth. Succeeds best in shady places.

$$
\begin{aligned}
& \text { Each Per } 10 \text { Per } 100
\end{aligned}
$$

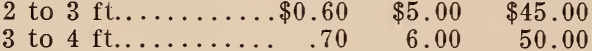

\section{SYRINGA Japonica-Tree Lilac.}

A species from Japan which becomes a good sized tree. Foliage dark, glossy green. Flowers creamy white and odorless. Bloom a month later than other lilacs.

$$
\begin{aligned}
& \text { Each Per } 10 \\
& 3 \text { to } 4 \mathrm{ft} . . \ldots \ldots \ldots \ldots \ldots \ldots \ldots 1.25 \$ \$ 10.00 \\
& 4 \text { to } 5 \mathrm{ft} . \ldots \ldots \ldots \ldots \ldots \ldots \ldots \ldots
\end{aligned}
$$

\section{S. Persica-Persian Lilac.}

This variety flowers in May. Color of bloom, dark purple. Usual height, four to six feet.

Eaclı Per 10 Per 100

2 to $3 \mathrm{ft} . \ldots \ldots \ldots \ldots \$ 0.90 \quad \$ 8.50 \quad \$ 75.00$

3 to $4 \mathrm{ft} . \ldots \ldots \ldots . . . .1 .00 \quad 9.00 \quad 80.00$

S. Rothomagensis Syn. Chinensis-Rouen Lilac.

An abundant bearer of dark red flowers in large panicles. Flowers in June.
2 to $3 \mathrm{ft} . \ldots \ldots \ldots \ldots 0.90$
Per 10 Per 100
3 to $4 \mathrm{ft} . \ldots \ldots \ldots \ldots 1.00 \quad 9.00 \quad 80.00$

S. Vulgaris Alba-Common White Lilac.

Single flowers of a beautiful creamy-white. 2 to $3 \mathrm{ft} . \ldots . . . . \$ 0.90 \quad \begin{array}{rrr}\text { Each } & \text { Per } 10 & \text { Per } 100 \\ \$ 8.00 & \$ 70.00\end{array}$

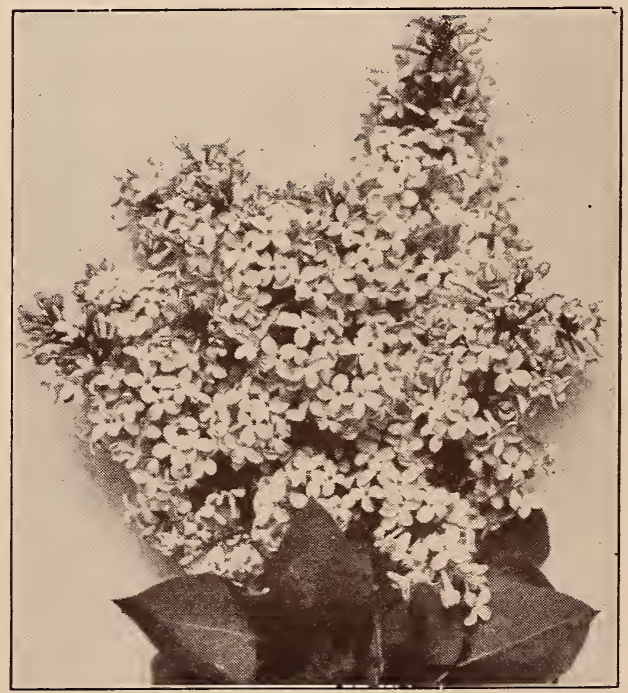

Common Lilac 


\section{S. Vulgaris-Common Purple Lilac.}

Bluish purple flowers or violet in color. Single. A standard variety.

\begin{tabular}{|c|c|c|}
\hline Each & Per 10 & Per 100 \\
\hline.$\$ 0.70$ & $\$ 6.00$ & $\$ 55.0$ \\
\hline to $4 \mathrm{ft}$.. & 7.00 & 65.0 \\
\hline . 1.00 & 9.00 & 80.0 \\
\hline
\end{tabular}

S. Vulgaris Josikaea.

Single, violet.

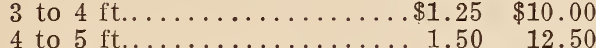

5 to $6 \mathrm{ft} \ldots \ldots \ldots \ldots \ldots \ldots 2.00 \quad 17.50$

French varieties of Lilacs.

The following list of varieties are grafted plants and are certain to bloom, as the grafts are taken from plants that have bloomed.

Prices on all French Lilacs:

Each Per 10

18 to 24 in..............\$1.00 \$9.00

2 to $3 \mathrm{ft} . \ldots \ldots \ldots \ldots \ldots \ldots \ldots \ldots$

S. Vulgaris Chas. Joly.

Double, dark, purplish-red flowers.

S. Vulgaris Casimir Perier.

Double, cream colored flowers, deliciously scented. Fine for cutting.

\section{S. Vulgaris Chas. $\mathrm{X}$.}

Single flowers, of reddish-purple cast. This is a rapid growing variety with large glossy leaves.

\section{S. Vulgaris Hugo Koster.}

Single, dark reddish-purple.

\section{S. Vulgaris Marie Legraye.}

Single, white. Panicles large. One of the finest white.

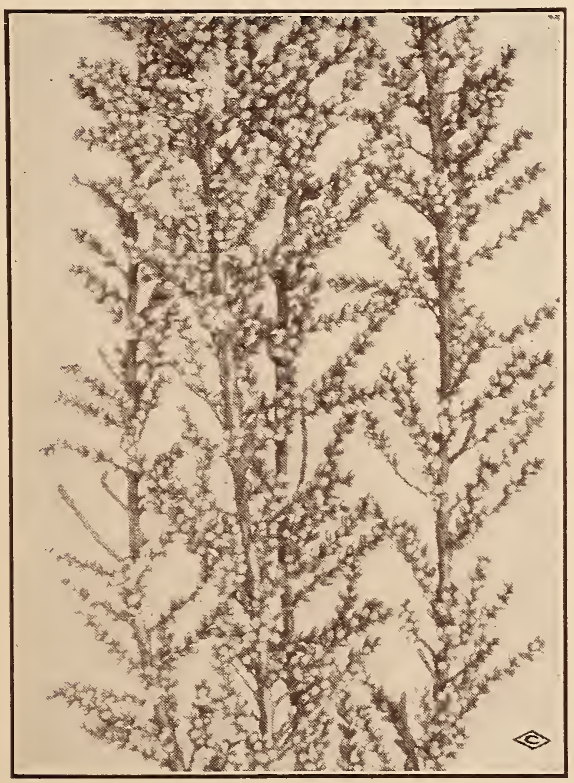

Tamarix

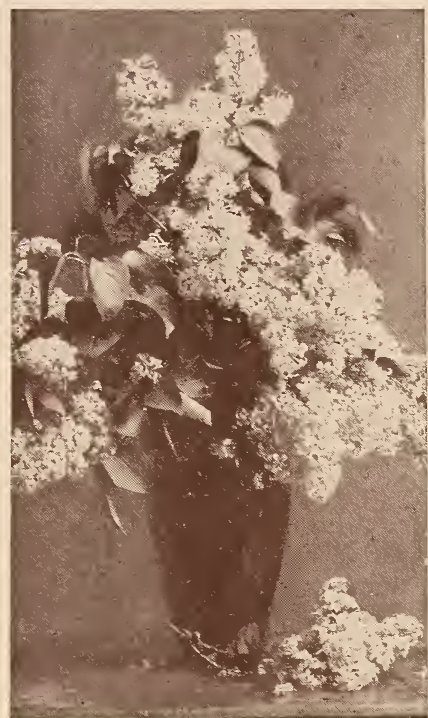

Persian Lilacs

S. Vulgaris Michael Bouchner.

Double flowers of pale lilac.

S. Vulgaris Mme. Lemoine.

Double, white.

S. Vulgaris President Grevy.

Double flowers of dark blue and very beautiful.

\section{S. Vulgaris Souvenir de Ludwig Spaeth.}

Long panicles. Large individual flowers. Color of flowers, dark purplish-red.

\section{TAMARIX Africana.}

Bright pink flowers in slender racemes in April and May. Shrub is tall and is very showy with its reddish bark.

Prices on all Tamarix except where noted:

$\begin{array}{rrrr}3 \text { to } 4 \mathrm{ft} \ldots \ldots \ldots \ldots \ldots .75 & \$ 7.00 & \$ 60.00 \\ 4 \text { to } 5 \mathrm{ft} \ldots \ldots \ldots \ldots & .80 & 7.00 & 65.00 \\ 5 \text { to } 6 \mathrm{ft} \ldots \ldots \ldots \ldots & 1.00 & 9.00 & 80.00\end{array}$

\section{T. Amurense.}

Similar to T. Pentandra. Purple branches. Valuable for its graceful foliage. Loves dry soil.

\section{T. Gallica.}

Delicate pink or white flowers in slender panicled racemes in spring or early summer. Leaves bluish-green. Grows to fifteen feet high. 


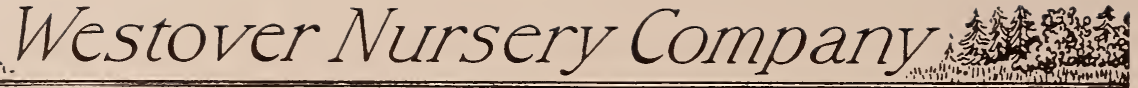

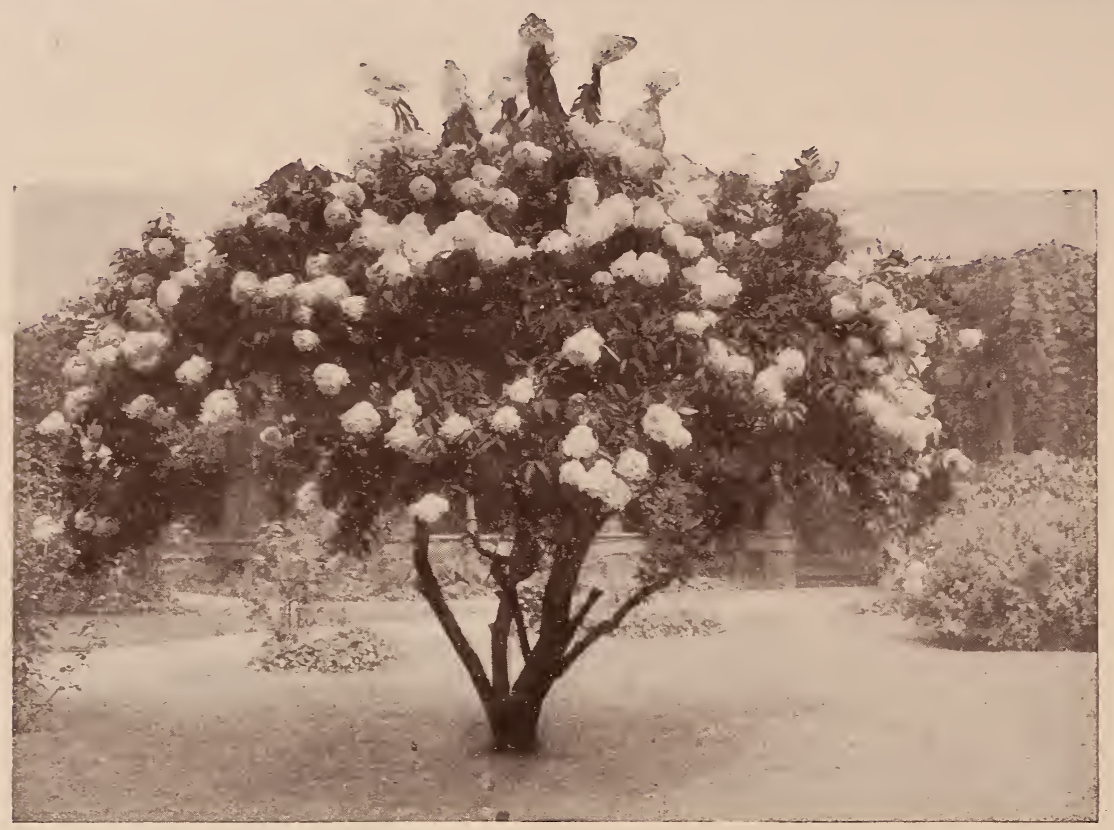

Snowball

\section{T. Gallica Indica.}

Pink flowers in longer, more wand-like sprays. Foliage is dull green.

\section{T. Japonica Plumosa.}

Pink.

\section{T. Odessana.}

Tall, pink.

\section{T. Hispida Aestavilis.}

A pink flowered variety. Blooms in August and September. Desirable. Best for cut flowers.

Each

3 to $4 \mathrm{ft} . \ldots \ldots \ldots \ldots \$ 0.85$

4 to $5 \mathrm{ft} . \ldots \ldots \ldots 1.00$
Per 10 Per 100

$\$ 7.50 \$ \$ 0.00$

\section{VIBURNUM Dentatum-Arrow Wood.}

Flowers greenish-white. One of the best shrubs for massing for foliage effects.

Each Per 10 Per 100

4 to $5 \mathrm{ft} . \ldots \ldots \ldots \ldots \$ 1.00 \quad \$ 9.00 \quad \$ 85.00$

5 to $6 \mathrm{ft} \ldots \ldots \ldots \ldots .1 .25 \quad 10.00 \quad \ldots \ldots$

\section{Lantana-Wayfaring Tree.}

A large, robust shrub, with soft, heavy leaves and large clusters of white flowers in May, succeeded by red fruit. Retains its foliage very late.

Each Per 10 Per 100

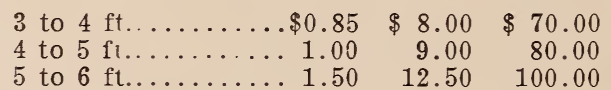

V. Lentago-Sheepberry.

Flowers creamy-white and very fragrant. Foliage a light glossy green.

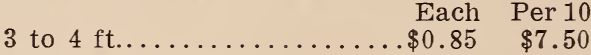

4 to $5 \mathrm{ft} \ldots \ldots \ldots \ldots \ldots \ldots \ldots \ldots$

\section{Molle.}

A robust growing shrub, with cymes of white flowers, which appear later than those of the other Viburnum.

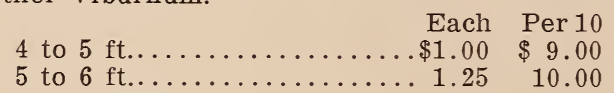

\section{Opulus-High Bush Cranberry.}

Both ornamental and useful. Its red berries, resembling cranberries, esteemed by many, hang until destroyed by frost in the fall.

\begin{tabular}{|c|c|c|c|}
\hline & Each & Per 10 & Per 100 \\
\hline 2 to $3 \mathrm{ft}$. &.$\$ 1.00$ & $\$ 9.00$ & $\$ 80.00$ \\
\hline 3 to $4 \mathrm{ft}$. & . 1.25 & 11.00 & 100.00 \\
\hline 4 to $5 \mathrm{ft}$. & 1.50 & 12.50 & 110.00 \\
\hline 5 to $6 \mathrm{ft}$. & 1.75 & 15.00 & \\
\hline
\end{tabular}

\section{Plicatum-Japanese Snowball.}

Comes from North China. Of moderate growth, blooms with handsome globular heads of pure white neutral flowers early in June. Surpasses the common snowball in several respects. Its habit is better, foliage much hand. somer, flowers whiter and more delicate.

Each Per 10

2 to $3 \mathrm{ft} . \ldots \ldots \ldots \ldots \ldots \ldots \ldots 1.00 \ldots \ldots \ldots \ldots$

3 to $4 \mathrm{ft} \ldots \ldots \ldots \ldots \ldots \ldots \ldots \ldots 1.25 \quad 10.00$ 


\section{Opulus Sterilis-Common Snowball.}

A well known favorite shrub, of large size, with clusters of pure white sterile flowers the latter part of May. Each Per 10 Per 100

3 to $4 \mathrm{ft} . \ldots \ldots \ldots \ldots \$ 1.25 \quad \$ 11.00 \quad \$ 100.00$

4 to $5 \mathrm{ft} \ldots \ldots \ldots \ldots 1.50 \quad 12.50 \quad 110.00$

5 to $6 \mathrm{ft} \ldots \ldots \ldots \ldots 1.75 \quad 15.00 \quad \ldots \ldots$

\section{Prunifolia-Blackhaw.}

Tall, spreading; handsome foliage; fruit b!uish-black. Each Per 10

3 to $4 \mathrm{tt} . \ldots \ldots \ldots \ldots \ldots \ldots \ldots \$ 1.00 \$ 9.00$

4 to $5 \mathrm{ft} . \ldots \ldots \ldots \ldots \ldots \ldots \ldots$

\section{Sieboldii.}

Siebold Viburnum. Tall upright; beautiful white flowers. Very effective foliage and bright red berries in mid-summer.

Each Per 10

4 to $5 \mathrm{ft} . \ldots \ldots \ldots \ldots \ldots \ldots \ldots \$ \ldots \ldots \ldots$

5 to $6 \mathrm{ft} \ldots \ldots \ldots \ldots \ldots \ldots \ldots \ldots \ldots 1.25 \quad 10.00$

V. Tomentosum.

The single form of the beautiful Japanese Snowball. The flowers are pure white, borne along the branches in flat cymes, in great profusion, early in June. Perfectly hardy, vigorous, and free blooming.

3 to $4 \mathrm{ft} . \ldots \ldots \ldots \ldots \ldots \ldots \ldots 1.25 \$ \$ 11.00$

4 to $5 \mathrm{ft} . \ldots \ldots \ldots \ldots \ldots \ldots 1.50 \quad 12.50$

\section{VITEX Agnus Castus-Chaste Tree.}

A graceful shrub, growing to 5 or 6 feet high with dense spikes of Lilac colored flowers late in summer.

2 to 3 ft........\$ \$0.60 $\$ 5.00 \quad \$ 45.00$

3 to $4 \mathrm{ft} . \ldots \ldots \ldots \ldots .70 \quad 6.00 \quad 55.00$

WEIGELIA Syn. Diervilla.

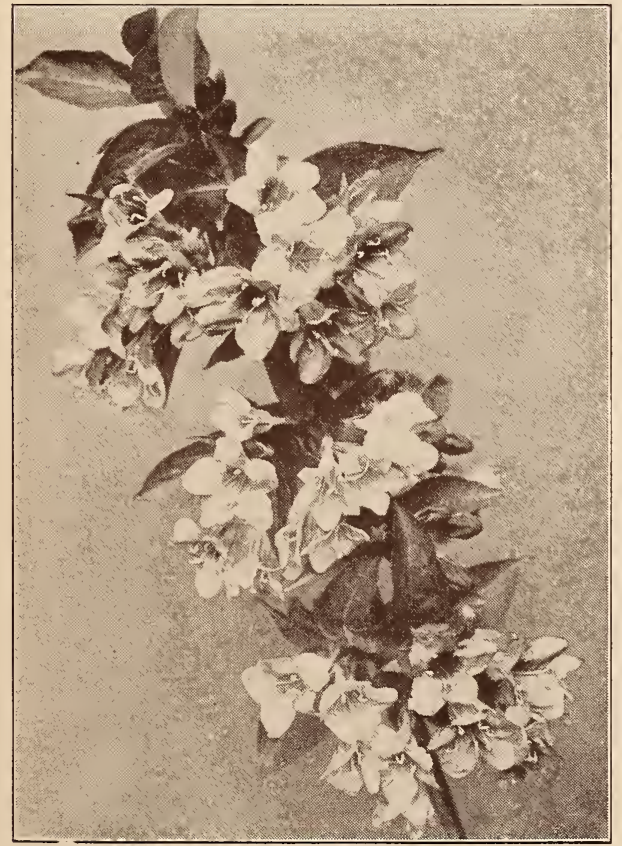

Weigelia

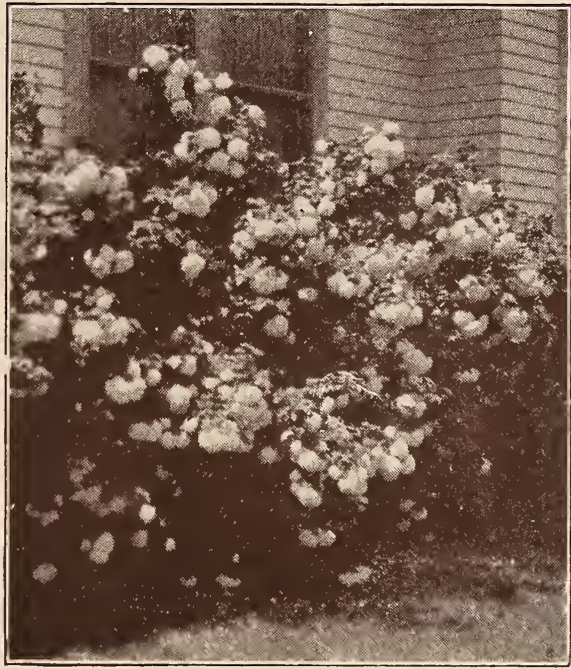

Japanese Snowball

W. Amabilis-Rose Weigelia.

A beautiful, distinct, pink flowering sort of this valuable shrub. Each Per 10 Per 100

2 to $3 \mathrm{ft} . \ldots \ldots \ldots \ldots \$ 0.70 \quad \$ 6.50 \quad \$ 60.00$

3 to $4 \mathrm{ft. \ldots . \ldots .....8} \quad .80 \quad 7.50 \quad 70.00$

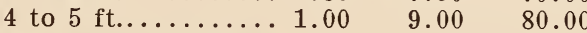

\section{W. Candida-White.}

Of vigorous habit, this erect flower becomes in time a large sized shrub. Flowers are pure white and produced in great quantities in June.

$\begin{array}{rrrr}2 \text { to } 3 \mathrm{ft} . \ldots \ldots \ldots \ldots . & \text { Each } & \text { Per } 10 & \text { Per } 100 \\ 3 \text { to } 4 \mathrm{ft} . \ldots \ldots \ldots \ldots & \$ 7.00 & \$ 60.00 \\ & .85 & 8.00 & 70.00\end{array}$

W. Eva Rathke-Crimson.

Flower a brilliant crimson, with a gorgeous and distinct clear shade.

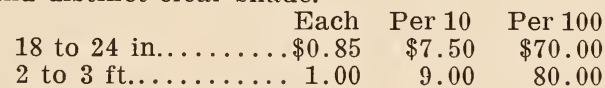

\section{W. Floribunda-Crimson.}

A June flowering variety of tall growth. The flowers, while small, are numerous and become a beautiful crimson when fully opened.

$\begin{array}{rrrrr}2 \text { to } 3 \mathrm{ft} . \ldots \ldots \ldots \ldots . \$ 0.80 & \$ 7.00 & \$ 65.00 \\ 3 \text { to } 4 \mathrm{ft} . \ldots \ldots \ldots . .90 & 8.00 & 70.00\end{array}$

W. Hendersonii-Pink.

One of the strongest growing varieties with large flowers of deep rose.

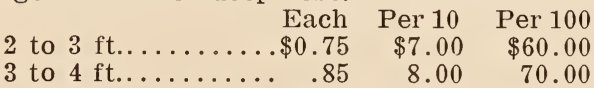

W. Diervilla Rosea-Light Pink.

An elegant shrub, with light rose colored flowers; of erect, compact growth, blossoms in June. Most popular of all.

$\begin{array}{rrrr}2 \text { to } 3 \mathrm{ft} . \ldots \ldots \ldots \ldots & \begin{array}{r}\text { Pach } \\ \text { Per } 10\end{array} & \text { Per } 100 \\ 3 \text { to } 4 \mathrm{ft} \ldots \ldots \ldots \ldots & \$ 7.00 & \$ 60.00 \\ 4 & 85 & 8.00 & 70.00\end{array}$

4 to $5 \mathrm{ft} . \ldots \ldots \ldots \ldots 1.00 \quad 9.00 \quad 80.00$

W. Variegata-Variegated-Leaved Weigala. Each Per 10 24 in..............\$0.75 $\$ 7.00$

2 to $3 \mathrm{ft} \ldots \ldots \ldots \ldots \ldots \ldots . .85 \quad 8.00$ 


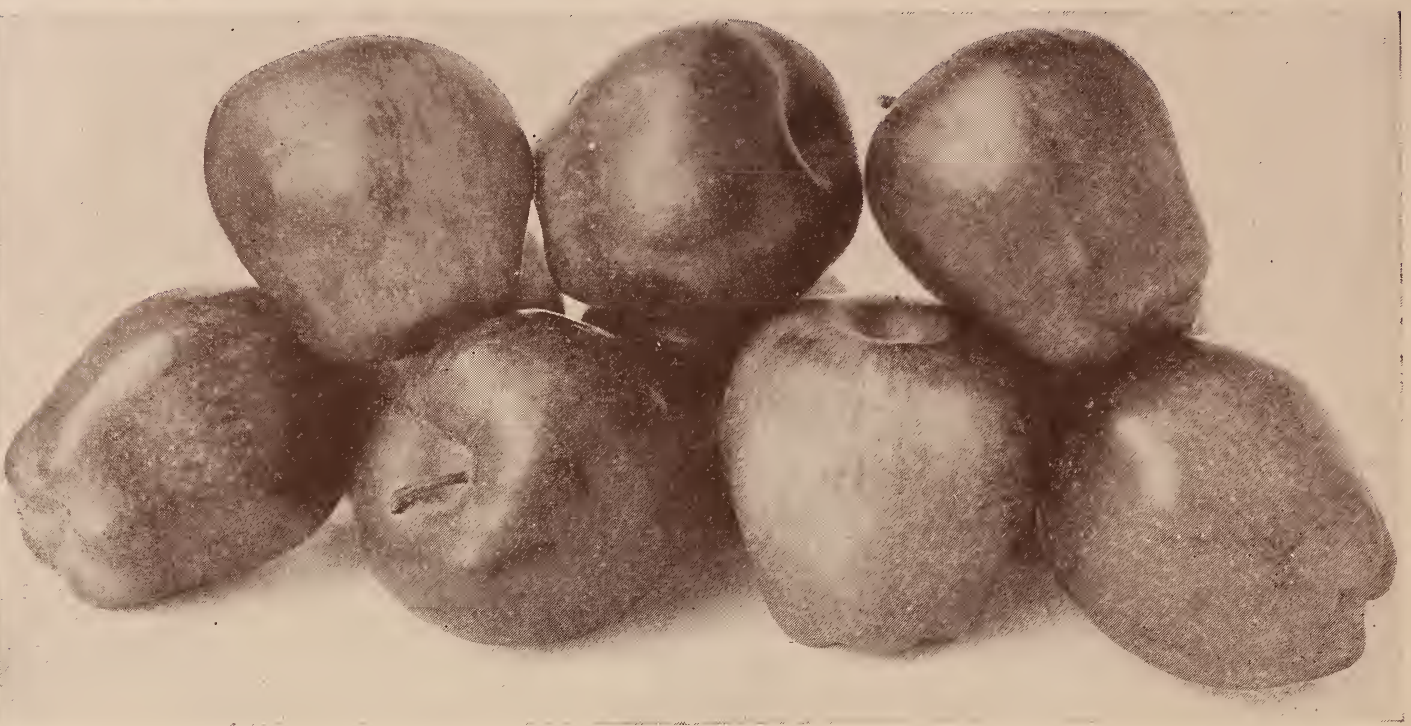

Delicious Apples

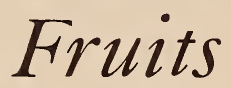

HE growing of hardy fruits has been increasing every year, and with the improved methods and improved varieties, success is almost an assured fact. Our stock of all the various fruit trees, vines and plants are in the best of condition, well rooted and free from disease, and grown under the most improved methods. You can be sure of getting just what you want when you order from us, along with the highest quality and reasonable prices.

\section{APRICOTS}

2 year, 4 ft.....Each, $\$ 1.00$; Per 10, $\$ 9.00$

\section{APPLES}

The Apple has rightfully been hailed the king of fruits. In its long continuance throughout the year and in its various uses, it possesses an importance not equalled by any other fruit. Many good apples in one section are not so good in another. Therefore, we have listed, in our descriptions, both the good and bad points of each variety. You may safely depend upon them.

Prices on all Apples:

2 year, 5 to $6 \mathrm{ft}$.. Each, $\$ 0.80$; Per $10, \$ 7.00$

ARKANSAS BLACK-Winter.

Beautiful dark red, late keeping and of very good quality, demanding a good price on the market. Fruit medium and very uniform in size and shape.

\section{YELLOW TRANSPARENT-Early.}

One of the best extra early apples. Splendid for culinary uses and dessert. Excellent for home or commercial orchard. Apple sauce made from this variety is better than any others. Skin smooth, waxy, pale greenish yellow changing to an attractive yellowish white. Flesh moderately firm, fine grained, crisp and tender. Sub-acid taste with a pleasant flavor.
GANO-Winter.

A superior variety of the Ben Davis. Skin a smooth, waxy and pinkish red. Flesh is rather coarse, whitish and firm, good or nearly good in quality. Tree a very vigorous grower and prolific bearer.

\section{GRIMES GOLDEN-Early Winter.}

Fruit medium to large. Color is a clear, deep yellow with scattering pale or russet dots. Flesh moderately juicy, firm, crisp and tender. Fine for desserts or culinary purposes. One of the best pure yellow winter apples. Fine for either commercial or home orchard.

\section{JONATHAN-Winter.}

One of the most desirable for fancy trade during holiday season. Fruit medium to small, rarely large, and of a pale yellow color, overlaid with red and striped with carmine. Flesh is firm, crisp and tender, juicy and very aromatic. Fine for table use or for culinary purposes. Reliable biennial cropper, coming into bearing rather young. Season, November to January. 


\section{DELICIOUS-Winter.}

This is a large apple with a surface covered with a brilliant dark red, blending to golden yellow at the blossom end. The tree is hardy, healthy and vigorous and bears regular annual crops. Flesh is fine grained, crisp and melting, juicy and wonderfully aromatic. Keeping qualities good.

\section{RED JUNE-Early.}

Medium size, red; flesh white, tender, juicy, sub-acid and abundant bearer. July.

\section{STAYMAN'S WINESAP - Winter.}

One of the finest apples for fancy trade. Of uniformly handsome appearance. Fruit, when well colored, a deep, almost purplish red. Flesh yellow, firm and crisp, of a distinctive, mildly sub-acid tlavor and inclined to be dry. Tree a favorite in Middle-West and South, but will

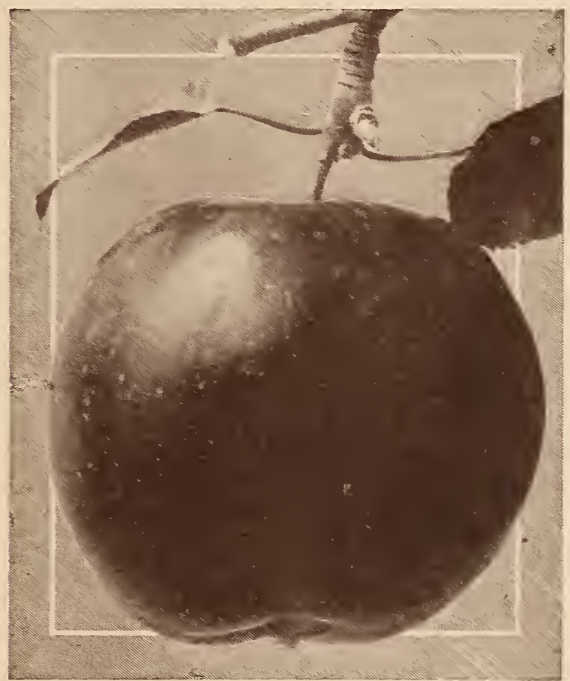

Stayman's Winesap

grow and do well almost anywhere. A reliable annual bearer, beginning young.

\section{YORK IMPERIAL-Winter.}

This is rapidly becoming an important com mercial variety. Fruit greenish-yellow, nearly covered with bright red. Crisp, tender, aromatic and juicy. A good keeper. Tree is a vigorous grower and exceedingly productive, holding its fruit remarkably against wind. Not recommended for the extreme north.

\section{CRAB APPLE}

HYSLOP -

Large, deep crimson, with beautiful bloom. Very prolific and popular. A showy fruit that makes the finest kind of jelly. Mid-autumn to January. Tree hardy, vigorous and productive. Each.......\$0.90 Per $10 \ldots \ldots \ldots \$ 8.00$

\section{YELLOW SIBERIAN-}

Fruit small, round; flavor sour and acid; excellent for jelly, but too small for other purposes.

Each......\$0.90 Per $10 \ldots \ldots \ldots 8.00$

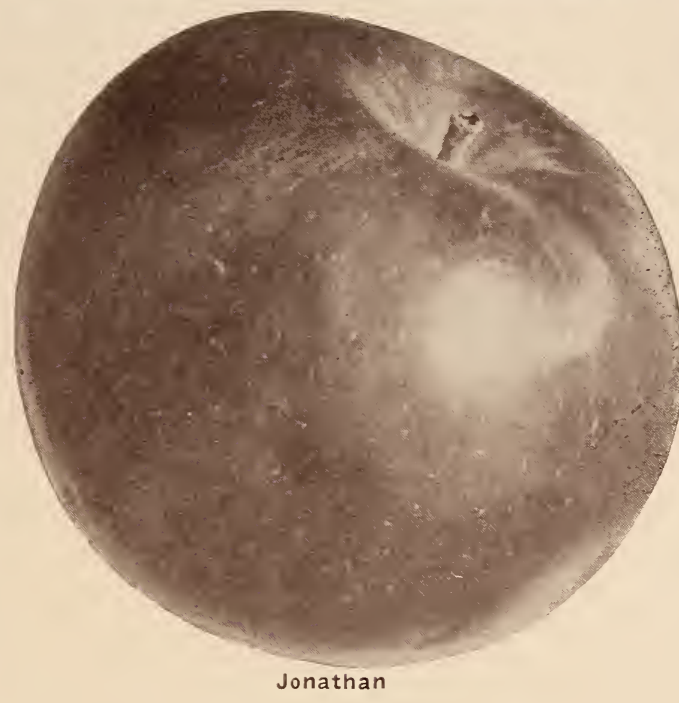

PEACHES

Prices on all Peaches:

5 to 6 feet........Each, $\$ 0.65$; Per $10, \$ 5.00$

\section{BELLE-Belle of Georgia.}

The best early September market peach. A standard commercial variety, planted by nearly all growers, ripening with old Mixon, which it has largely superceded. Fruit very large, white with red cheek, very free stone. Fair quality.

\section{CHAMPION-}

The earliest, iron-clad peach. Remarkable for its size and free stone of high quality. White, with red cheek. Season, late August. Unexcelled for canning.

\section{CARMAN-}

One of the liardiest, most reliable market peaches. Large, rich, juicy and of fair quality. Yellow-white, with deep blush. Skin very tough, making a good shipper and free from rot.

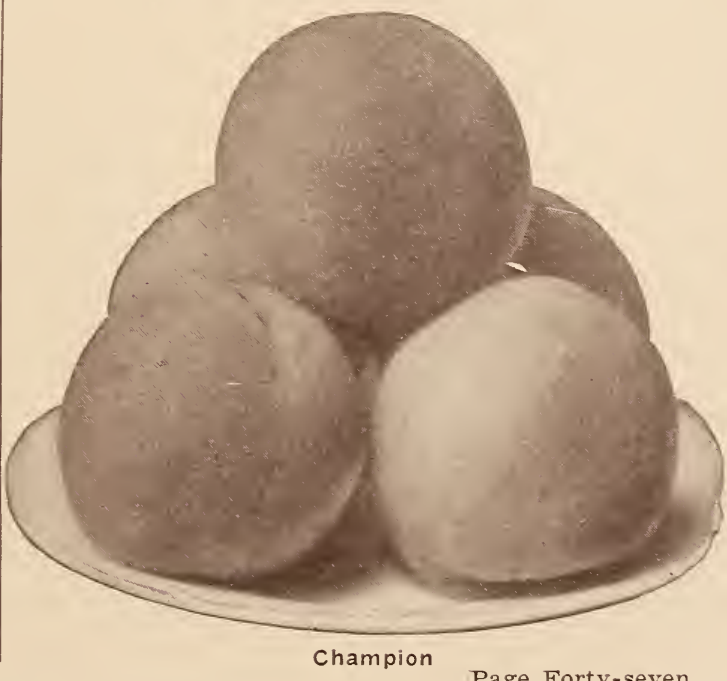




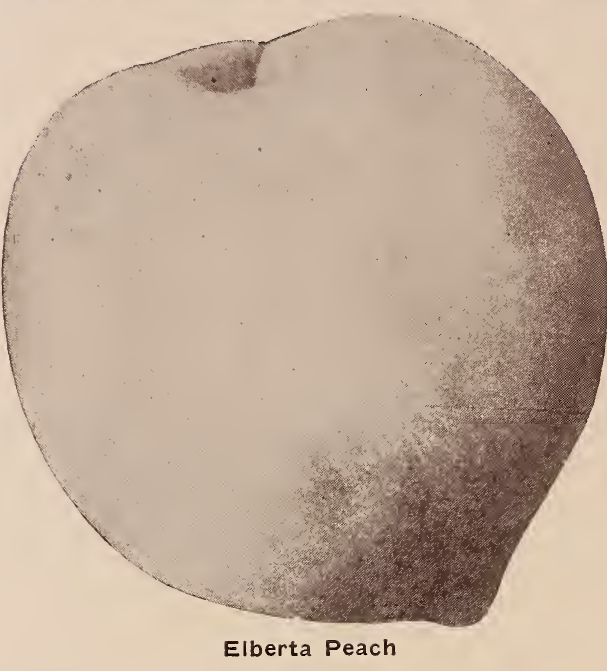

\section{CRAWFORD EARLY-}

Has long held its position as the favorite yellow free stone. Fruit highly flavored, rich and abundantly juicy. Very large, golden yellow, blushed with dark red. Trees healthy and vigorous, but a relatively spare bearer. Season, late August to early September.

\section{ELBERTA-}

The peer of all commercial peaches. Midseason, extra large, light yellow with red cheek, a perfect free stone. Tree vigorous and prolific, and succeeds universally wherever peaches can be grown.

\section{GREENSBORO-}

The most popular July peach. A white fleshed, free stone. Fruit large and showy. Ships and stands up well. Skin greenish white, blushed and striped with red. Tree enormously productive and early bearing.

\section{J. H. HALE-}

One of the largest of peaches. Superior to Elberta in size, firmness and shipping qualities. Yellow and red coloring. Very attractive but is not as prolific as a commercial fruit should be. Flesh fine grained and quality good.

\section{HEATH CLING-}

The oldest named American Peach. Valuable for its hardiness, freedom from disease and excellence for preserving or pickling. Color creamy white blushed with red. Ripens very late, about three weeks after Elberta.

\section{PEARS}

Price on all Pear:

2 year, 5 to $6 \mathrm{ft}$. Each, $\$ 1.00$; Per $10, \$ 9.00$

\section{ANJOU-}

A large, fine pear, with buttery, melting llesh, having a sprightly flavor. Tree a fine glower and very productive. One of the best of the season. October to January.

\section{BARTLETT-}

Fruit is large, yellow with a beautiful blush. Flesh very buttery, juicy and has a rich, musky flavor. Vigorous and erect grower. Fine for garden or commercial use. Bears early and abundantly. A leader among canning pears. August and September.

\section{DUCHESS-}

Very large, greenish-yellow, russeted. Flesh melting and sweet. A beautiful tree and a heavy bearer. Does its best as a dwarf. Season. October and November.

\section{SECKEL-}

Small, but universally popular. Rich, yellowish brown. One of the best and highest flavored pears known. Very productive. September and October.

\section{CLAPP'S FAVORITE-}

A large, fine pear, resembling the Bartlett, but without its musky flavor. Pale lemon yellow, with brown dots, and fine texture. Flesh melting and juicy. Has a delicate flavor. Tree hardy and productive. Season, August and September.

\section{GARBER-}

A Japanese hybrid. The best and handsomest of its class. Earlier than Kieffer, larger and much better quality. Tree very hardy, vigorous and productive.

\section{KIEFFER-}

The most popular market pear ever grown. Fruit of good size, rich color and fair quality. Should be picked at maturity and ripened indoors. Tree a rapid grower anywhere, vigorous and seldom blights. Season, October and November.

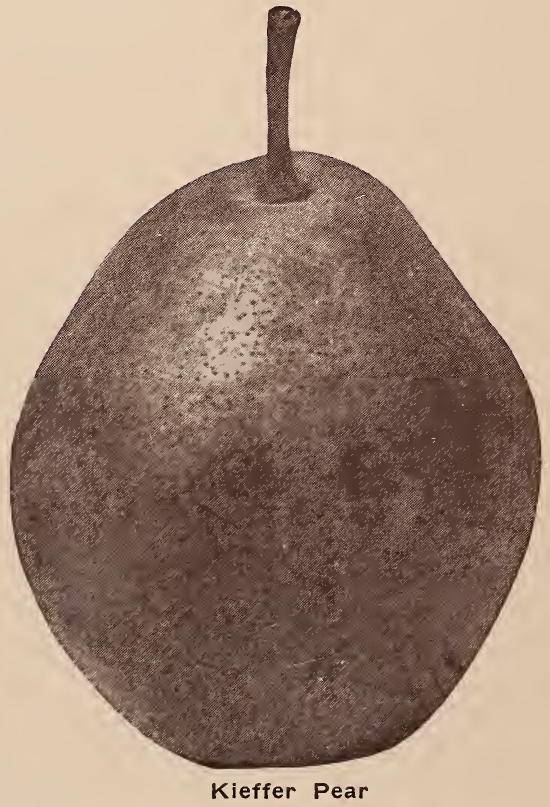




\section{CHERRIES}

Price on all Cherry:

2 year, $4 \mathrm{ft}$.....Each, $\$ 1.35$; Per $10, \$ 12.50$

\section{BLACK TARTARIAN-}

More largely planted than other sweet cherry. Dark red, almost purple. Medium size. Quality very good. Tree vigorous and productive. Season, last of June into July.

\section{MAY DUKE -}

The "Dukes" as a class are intermediate in favor between the sweet and sour varieties of cherries. This can be considered one of the best of them all, as well as the earliest. Large, dark red, rich, juicy and excelent. Tree is a reliable producer. Season, June.

\section{MONTMORENCY -}

The most popular sour cherry in America. Large, light red. Flesh tender, sub-acid and of best quality. Season, end of June to July. Tree hardy and enormously productive.

\section{EARLY RICHMOND-}

The earliest popular sour cherry. Medium sized red, quite acid. Hardy, healthy and very productive. Season, mid-June.

\section{GOV. WOOD -}

Size large to very large. Rich, light yellow amber, blushed with red. Of excellent quality. Season, late June.

\section{WINDSOR-}

Deep purple. Large, firm and of high quality. The leading late sweet cherry and claimed to be the hardiest. Tree a prolific bearer.

\section{PLUMS}

Price on all Plum:

2 year, 5 to $6 \mathrm{ft}$. Each, $\$ 1.00 ;$ Per $10, \$ 9.00$ SHROPSHIRE DAMSON-

A well known English variety. One of the best for preserving. Tree a poor grower but hardy, self-fertile and productive when under good culture. Season, early October.

\section{GERMAN PRUNE-}

Probably the oldest plum grown. Known in every civilized country. Skin is a purple black with beautiful bloom. Flesh is firm, sweet and mild. Tree is fairly hardy, holds its fruit well, but is inclined to overbear. Season is late.

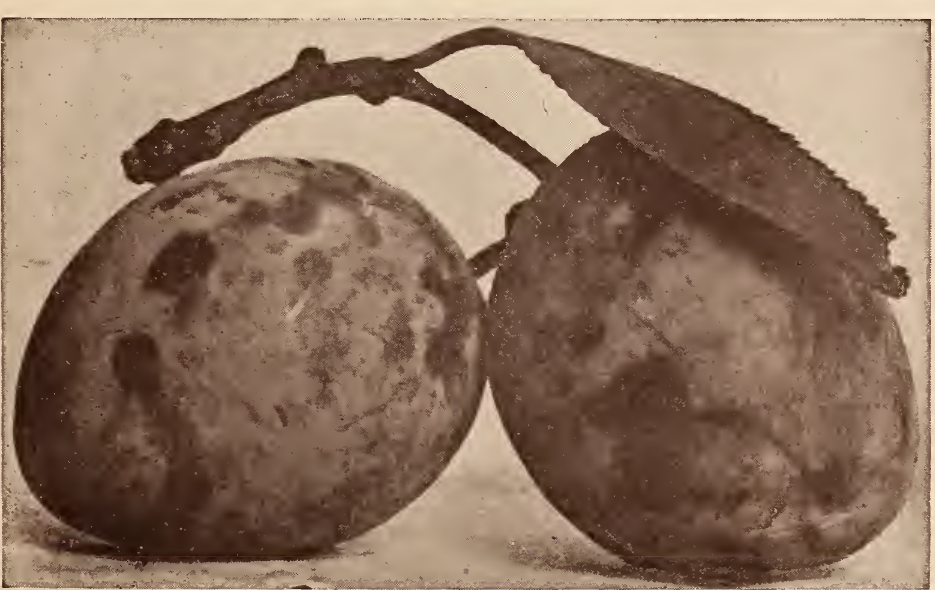

Burbank Plums

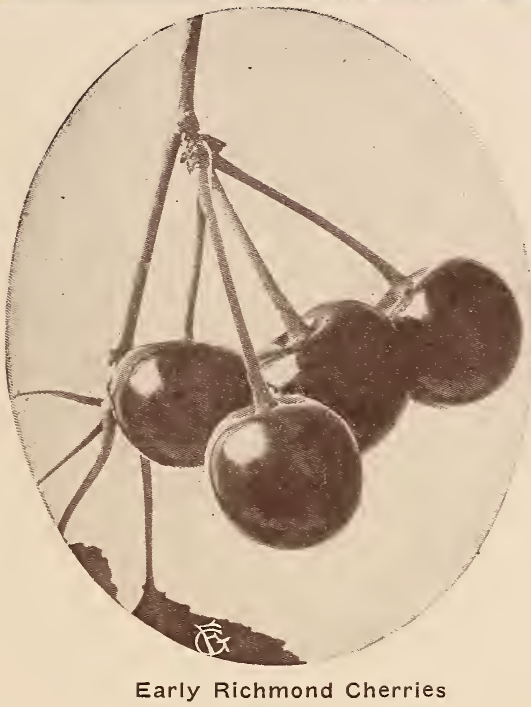

\section{ABUNDANCE-}

One of the most successful of the commercial varieties. Flesh is yellow, sweet and melting, and withal, very tender and juicy. Tree is a vigorous grower, reliably hardy and prodigiously productive. One of the earliest.

\section{WICKSON-}

Originated by the late Luther Burbank of California. Stands pre-eminent among the various Japanese varieties. Tree hardy and upright. A strong grower. Very productive. Fruit largest of all the Japans. Flesh is dull yellow and meaty. Destined to become one of the most valuable plums for the market. Tree is somewhat tender in the cold climates. Middle of September.

\section{WILD GOOSE-}

Well known, large, deep red when ripe; good quality; one of the best native plums. Should be in every orchard.

\section{COMPASS CHERRY-}

One of the hardiest varieties; b e a r s profusely. Fruit small, red.

\section{BURBANK-}

One of the largest of the Japanese varieties. Of uniform, attractive red color mottled over a yellow ground. Flesh is a deep lemon-yellow of excellent quality, yet firm and good shipper for so large a fruit. Tree is a vigorous grower and very productive. Reliably self-fertile. Season, late August to September.

\section{RED JUNE-}

A very vigorous upright grower; productive, fair size; vermillion red; pleasant quality. 


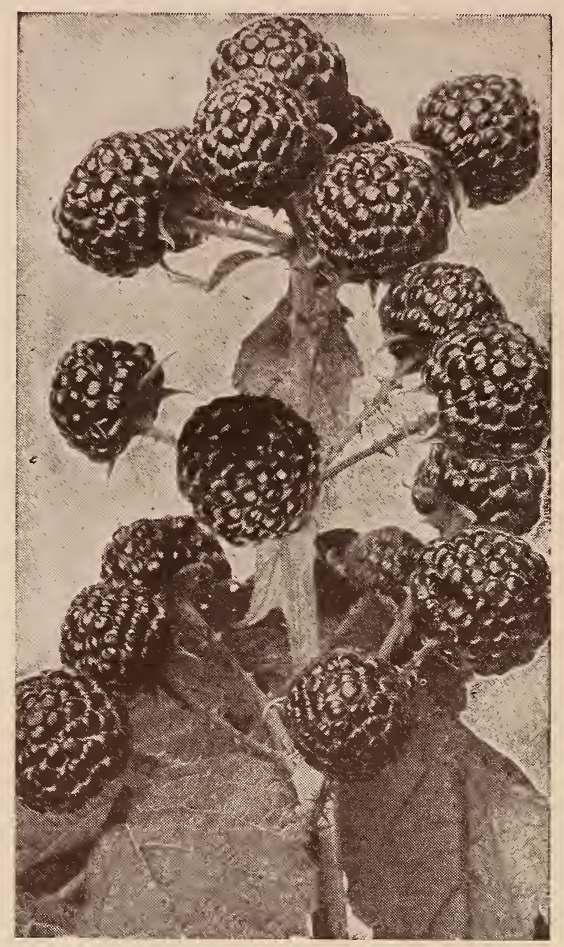

St. Regis Raspberries

\section{QUINCE}

2 year ........Each, $\$ 1.25$ Per $10, \$ 12.50$

\section{ORANGE-Apple Quince.}

The most popular and extensively cultivated old variety. Fruit is large, round, bright yellow-golden color, cooking tender, and of excellent quality. Tree is hardy and a very reliable grower.

\section{Small Fruits}

\section{CURRANTS}

\section{CHERRY -}

An old favorite. Of the largest size, but not as productive as its rivals. Plant of slow, sturdy growth, holding its fruit well up from the ground. Should be picked when first turning red. Fruit very acid and desirable for jelly making.

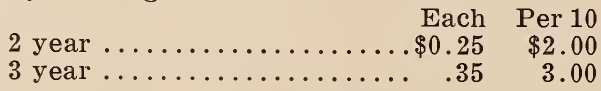

\section{FAY'S PROLIFIC-}

A cross between Cherry and Victoria. A most prolific and popular commercial variety. Berries of large size and fine sub-acid flavor. A healthy, vigorous grower.

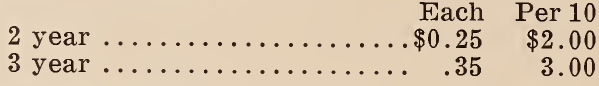

\section{GOOSEBERRIES}

\section{HOUGHTON-}

A distinctively American variety which never mildews. Fruit small to medium, pale red, tender, sweet and very good. Plant of spreading, rather than slender habit.

$\begin{array}{rrrr}\text { Each } & \text { Per } 10 & \text { Per } 100 \\ 2 \text { year old.........\$0.25 } & \$ 2.00 & \$ 15.00 \\ 3 \text { year old........ } & .50 & 4.00 & 35.00\end{array}$

\section{DOWNING-}

Pale green, large and handsome. The most popular market variety. Fruit covered with a white bloom that makes it very atractive. Bush a strong grower and very productive and healthy. Quality excellent.

$\begin{array}{rrrr} & \text { Each } & \text { Per } 10 & \text { Per } 100 \\ 2 \text { year old ......... } \$ 0.30 & \$ 2.50 & \$ 20.00 \\ \text { 3 year old........ } & .50 & 4.00 & 35.00\end{array}$

\section{RASPBERRIES}

\section{CUTHBERT-}

This is the most popular of all commercial varieties. Succeeds over a large range of territory, both North and South. Sufficiently firm for shipping. Its deep red color is very familiar to the housewife. Not entirely hardy in the cold climates. Berries large and conical. Midseason to late.

Per $10, \$ 1.00 ;$ Per $25, \$ 1.50$; Per $100, \$ 5.00$

\section{CUMBERLAND-}

The largest and best mid-season blackcap. Healthy, vigorous and productive. Firm large berries, fine in quality. One of the hardiest varieties.

Per $10, \$ 1.00 ;$ Per $25, \$ 1.50$; Per $100, \$ 5.00$

\section{ST. REGIS-}

Berries bright crimson, large size and very juicy and sugary. Flesh firm and meaty. A good shipper. Wonderfully prolific. Ripens with the earliest and continues on young canes until October.

Per 10, $\$ 1.25$; Per 25, $\$ 2.00$; Per $100, \$ 6.00$

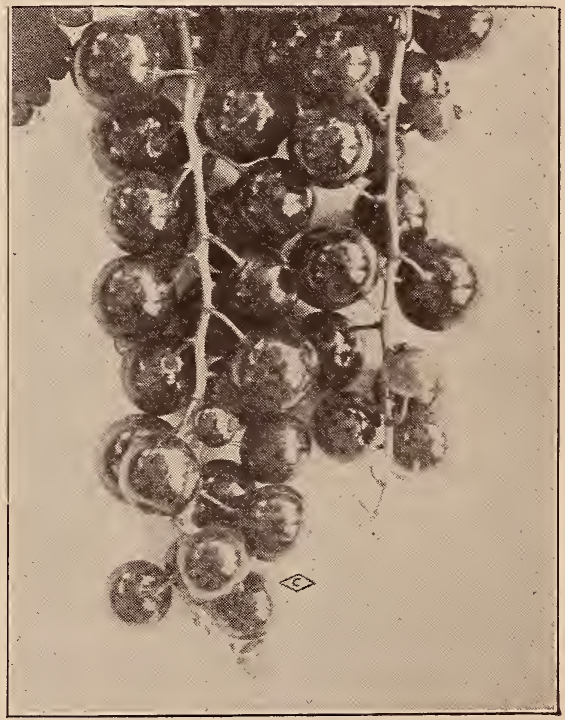

Currants 


\section{BLACKBERRIES}

EARLY HARVEST-

The earliest commercial variety. Very firm, medium size, good quality and very prolific.

Per $10, \$ 1.00$; Per $25, \$ 1.75$; Per $100, \$ 5.50$

\section{EL DORADO-}

Said to be the hardiest and sweetest blackberry. Withstands the coldest winters perfectly. Berries large to very large, borne in clusters. Very melting and sweet to the taste. Have no hard core, yet will keep perfectly for a week.

Per $10, \$ 1.25$; Per $25, \$ 2.25$; Per $100, \$ 7.00$

\section{DEWBERRY}

\section{LUCRETIA-}

This is the standard dewberry, ripening before, but selling as, a blackberry. Enormous in size but very sweet and tender. The best of the blackberry family, and under high culture, the most productive.

Per $10, \$ 1.25$; Per $25, \$ 2.00$; Per $100, \$ 6.00$

\section{GRAPES}

\section{AGAWAN-}

One of the most reliable. Purplish-red, of striking appearance and a very large berry. Sweet-ripens soon after the Concord-and a good keeper.

Each, $\$ 0.25$; Per $10, \$ 2.00$; Per $100, \$ 17.50$

\section{CONCORD -}

Still the most popular grape in America. It will adapt itself to almost any conditions.

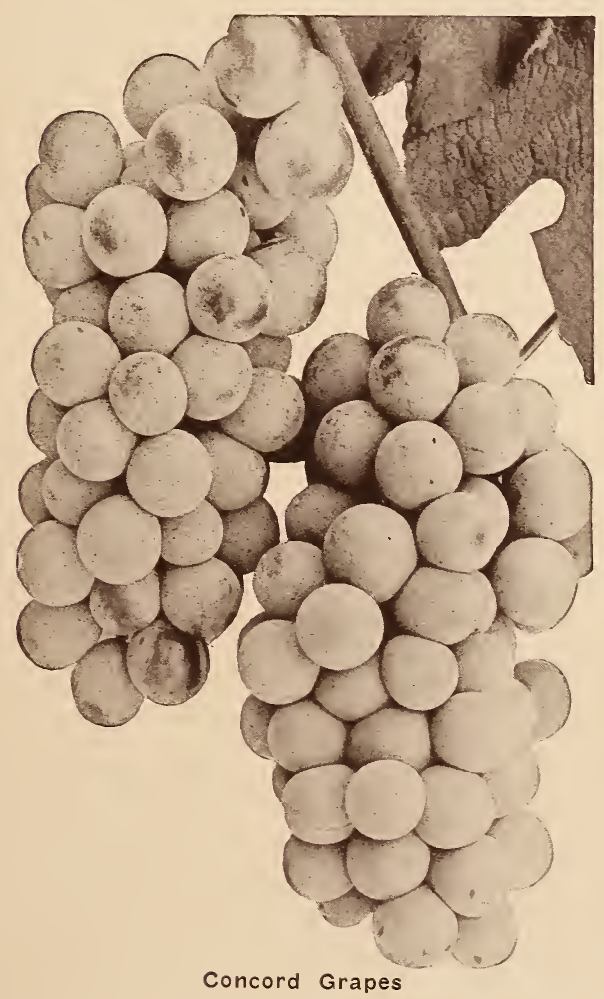

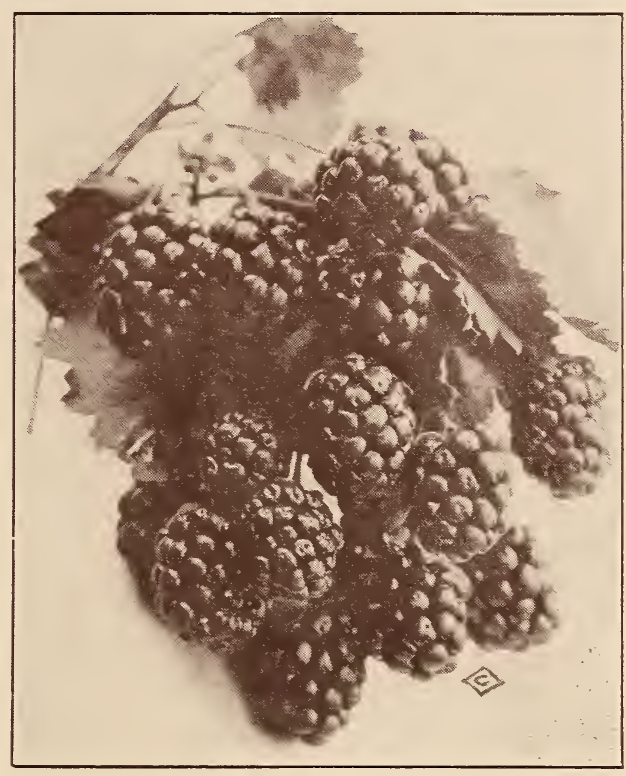

Eldorado Blackberries

Bunch and berry large, fair quality with rich bloom. Healthy and hardy and a very strong grower.

Each, $\$ 0.20$; Per $10, \$ 1.50$; Per $100, \$ 12.00$

\section{CAMPBELL'S EARLY-}

A strikingly handsome large black August grape with a fine bloom. Tough skin and a good shipper. Flesh sweet, though not highly flavored. Must be pruned closely. Inclined to overbear. Excellent commercial sort for northern climates.

Each, $\$ 0.40$; Per $10, \$ 3.50 ;$ Per $100, \$ 30.00$

\section{CATAWBA-}

A well known, late-ripening, chocolate colored grape of a rich, musky flavor. Demands high culture, a warm situation and a long season in which to properly mature.

Each, $\$ 0.25$; Per $10, \$ 2.00$; Per $100, \$ 17.50$

\section{MOORE'S EARLY-}

One of the best early blacks in the trade, selling for Concord but two weeks ahead of them and not as productive. Bunch medium size, inclined to looseness. Quality fairly good. Vine vigorous and hardy.

Each, $\$ 0.25$; Per $10, \$ 2.00$; Per $100, \$ 17.50$

\section{NIAGARA-}

Undoubtedly the most popular white grape. A typical commercial fruit, enormously productive and of fair quality. Ripens with Concord. Flesh is a little tender for shipping and keeping. Berries large. Vine is a rampant grower.

Each, $\$ 0.25$; Per 10, $\$ 2.25$; Per $100, \$ 20.00$

\section{WORDEN -}

Best known offspring of the Concord. One week earlier and superior to it in quality. Tender skin, however, and inclined to crack. Must be carefully handled in packing or shipping. Vine handsome and vigorous.

Each, $\$ 0.25$; Per 10, $\$ 2.00$; Per 100, $\$ 17.50$ 


\section{Westover Nursery Company}

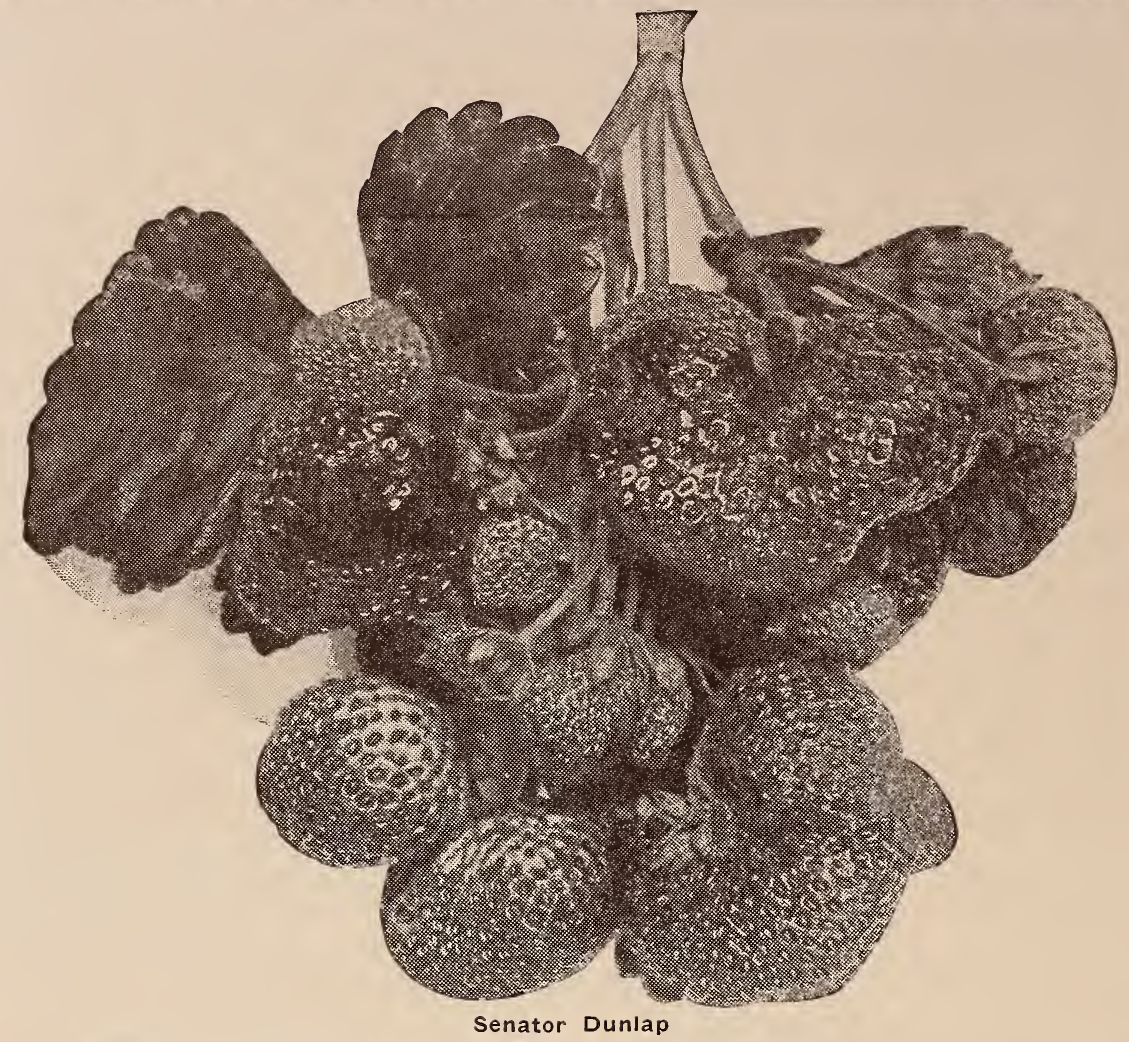

\section{STRAWBERRY}

\section{DR. BURRILL-}

A wonderful variety of the Illinois Strawberry known as the "Million Dollar Strawberry." Berries very large and uniform. This great variety is a strong fertilizer. An excellent market variety.

Per $25 \ldots \ldots \ldots \$ 0.60$ Per $100 \ldots \ldots \ldots \$ 1.50$

\section{GIBSON-}

One of the best and most profitable sorts for both home and market. Plants are strong growers with long roots and abundant foliage. Very productive. Berries extra large and finely flavored.

Per $25 \ldots \ldots \ldots \$ 0.60$ Per $100 \ldots \ldots \ldots 1.50$

\section{SENATOR DUNLAP-}

A medium to large berry, slightly flattened. Flesh is red, fine in texture and quality is excellent. Hardy and a good grower. Has been in existence for 25 years and is still a big favorite.

Per $25 \ldots \ldots \ldots \$ 0.60$ Per $100 \ldots \ldots \ldots 1.50$

\section{SAMPLE-}

A good late berry which is more largely planted as a commercial variety; a prolific bearer and good shipper.

Per $25 \ldots \ldots \ldots \$ 0.60$ Per $100 \ldots \ldots \ldots 1.50$

\section{WARFIELD-}

A very hardy and healthy and productive plant. Fruits are fine for canning purposes, mainly because they retain their color, shape and flavor. Berries are above medium in size, dark red to the center. A fine market sort.

Per $25 \ldots \ldots \ldots \$ 0.60$ Per $100 \ldots \ldots \ldots \$ 1.50$

\section{Everbearing Strawberries} PROGRESSIVE-

This is by far the best everbearing type. Fruit is of good size and of good color, plants vigorous and healthy, giving splendid pickings of high class berries for a long time. Fruit from the middle of July to the middle of November, according to season.

Per $25 \ldots \ldots \ldots \$ 1.00$ Per $100 \ldots \ldots . \$ 2.50$

\section{CONOVER-}

\section{ASPARAGUS}

Very large green shoots appearing very thick. A good standard variety.

Per 25.....\$1.00 Per $100 \ldots \ldots \ldots \$ 2.50$

\section{PALMETTO-}

A Southern variety of well merited popularity. A good yielder and very early.

Per $25 \ldots \ldots \ldots \$ 1.00$ Per $100 \ldots \ldots \ldots \$ 2.50$

\section{LINNAEUS - RHUBARB}

Those who have never grown this variety will hardly recognize it as the old "Pie Plant." It is of very superior quality, an early, tender variety, without being in the least bit tough or "stringy." Mild, sub-acid flavor.

Each, $\$ 0.15 ;$ Per $10, \$ 1.25$; Per $100, \$ 10.00$

\section{VEGETABLE PLANTS}

Per Dozen Per 100

Egg Plants, Tomatoes and

Peppers, $2 \frac{1}{2}$-inch pots.... $\$ 0.50 \quad \$ 4.00$

Cabbage Plants, not potted.. $\quad .40 \quad 3.00$ 

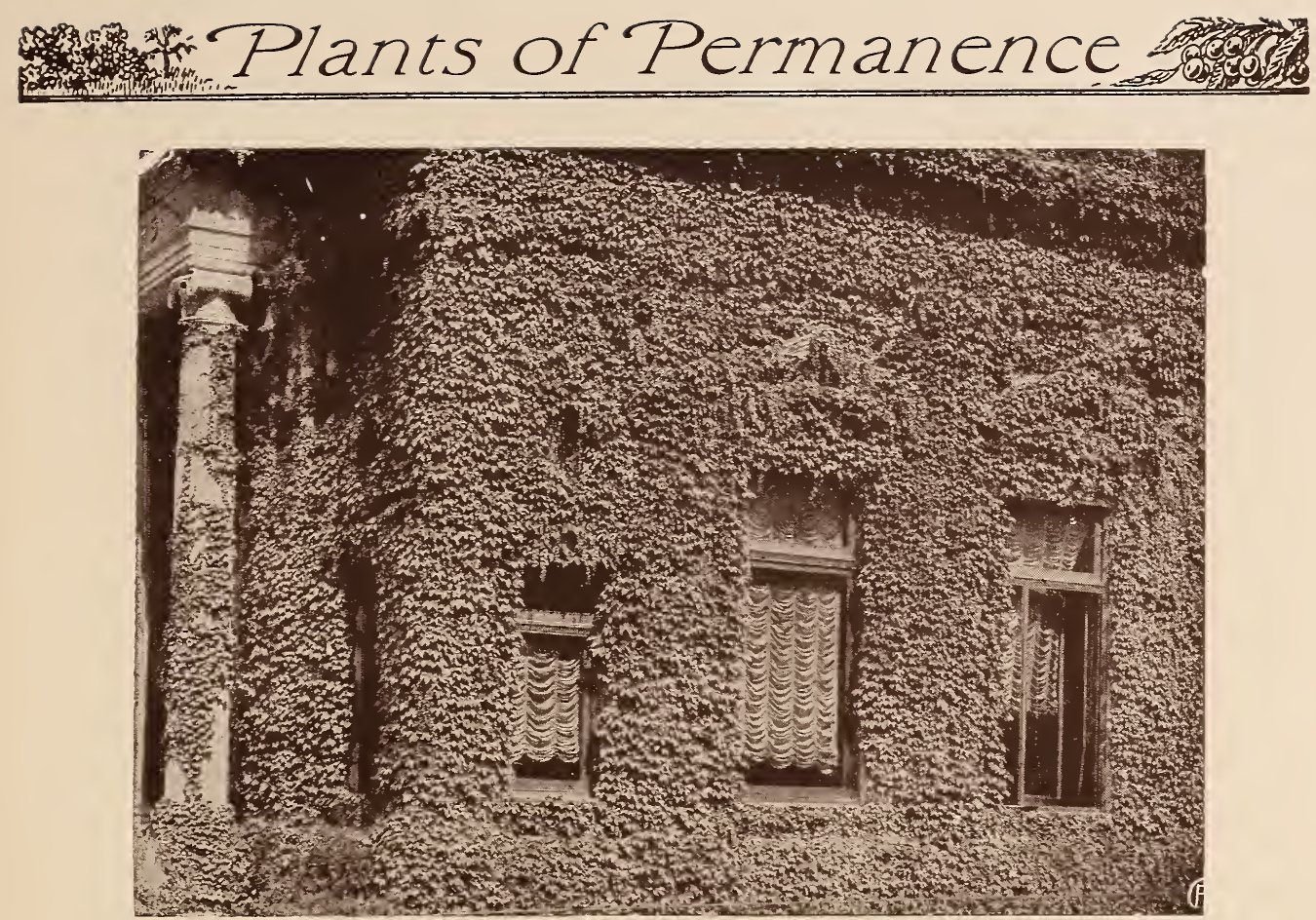

Boston Ivy

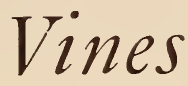

\section{AMPELOPSIS Quinquefolia-Virginia \\ Creeper.}

Rich crimson in autumn. A very rapid grower. One of the finest vines for trunks of trees, etc.

Each Per 10 Per 100

2 year ........\$0.45 $\$ 3.50 \quad \$ 30.00$

$$
\text { Pots ............... } 60 \text {. }
$$

\section{A. Engelmannii-Engelman's Ivy.}

A splendid climber, growing from six to ten feet in a season. Has become very popular, Grows like Virginia Creeper but clings to rough brick or stone better than Virginia Creeper.

Each Per 10

2 year ..............\$0.45 $\$ 3.50$

Pots .................. .60 5.00

A. Veitchii-Boston Ivy.

Of Japanese origin, entirely hardy, with foliage turning brilliant red in autumn. It is in our opinion the best and only vine that will really cling to brick or stucco walls.

$$
\text { Pots ............\$0.80 } \begin{array}{r}
\text { Each } 10 \\
\$ 7.00
\end{array}
$$

\section{ARISTOLOCHIA Sipho-Dutchman's Pipe.}

A magnificent hardy vine, with very large heart shaped leaves and brownish flowers, resembling in shape a miniature pipe. Splendid for archways and verandas. Each Per 10

$$
2 \text { year ..............\$1.00 } \$ 9.00
$$

BIGNONIA Radicans-Trumpet Vine.

A splendid, hardy, climbing plant, with large, trumpet-shaped scarlet flowers in August.

$$
\text { Each Per } 10
$$

2 year
CELASTRIS Scandens-Native Bittersweet.

A native climber, with handsome, glossy green foliage and large clusters of beautiful, orange-crimson fruits, retained all winter. Very bright in effect and charming for winter house decoration.

Each Per 10

3 year old.............\$0.50 \$4.00

5 year old, heavy stock..... $1.25 \quad 10.00$

\section{CLEMATIS Paniculata.}

A Japanese plant of unusual merit. Very rapid growth, quickly covering trellises and arbors with handsome, clean white flowers, borne in immense sheets and of a most wonderful fragrance. Flowers appear in September.

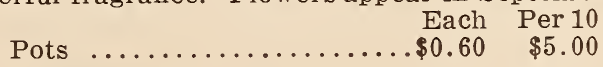

\section{Jackmanii.}

Large, intense, violet purple. Remarkable for its velvety richness. An abundant and successive bloomer.

Pots $\ldots \ldots \ldots \ldots \ldots \ldots \ldots 1.00 \quad \begin{array}{r}\text { Each } \\ \$ \$ 9.00\end{array}$

C. Henryi.

Large white.

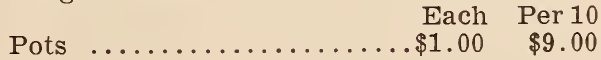

C. Mad. Ed. Andre.

Large crimson red.

Pots ...........\$1.00 $\begin{array}{r}\text { Each } \\ \$ 9.00\end{array}$ 


\section{EUONYMOUS Radicans.}

Trailing vine, small glossy foliage. Fine for buildings and as a ground cover. Clings to rocks and walls.

Each Per 10

E. Radicans Variegata.

Same as Radicans, with white and green foliage.

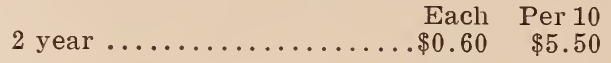

\section{E. Radicans Vegeta.}

This variety has beautiful, glossy green leaves, larger than the other varieties. The most valuable and evergreen.

Each Per 10

2 year ..............\$0.75 $\$ 6.50$

LONICERA Japonica Halleana-Hall's Japan

Honeysuckle.

A strong, fragrant, vigorous, evergreen sort with pure white flowers, changing to yellow.

Price on all Lonicera Vines:

$\begin{array}{rlrrr}2 & \text { year } \ldots \ldots \ldots \ldots & \text { Each } & \text { Per } 10 & \text { Per } 100 \\ 3 & \text { year } \ldots \ldots \ldots & \$ 4.00 & \$ 35.00 \\ & & & \end{array}$

\section{Periclymenum-Woodbine or Native} Honeysuckle.

A strong, fragrant, vigorous, Evergreen sort with carmine or purple buds opening into yellowish white flowers.

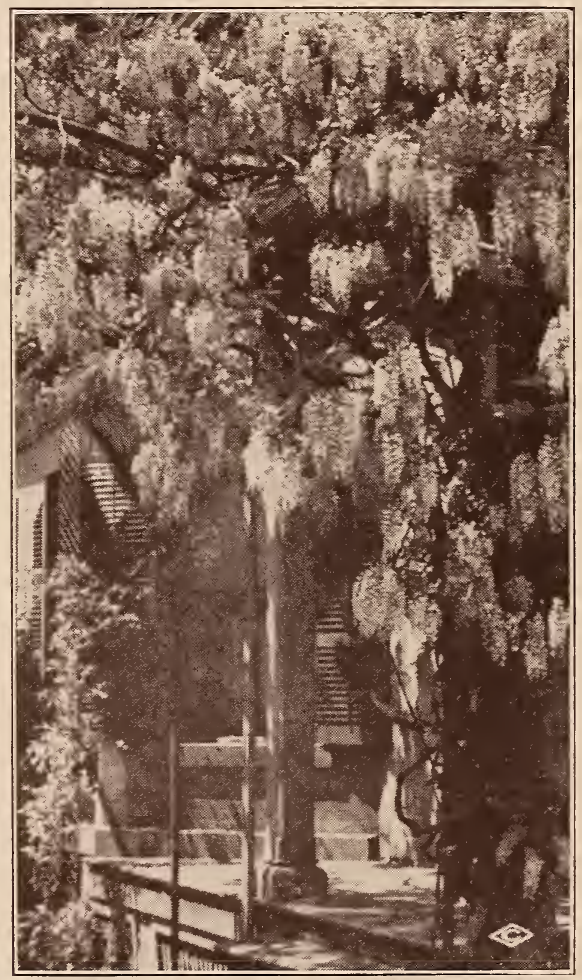

Wisteria

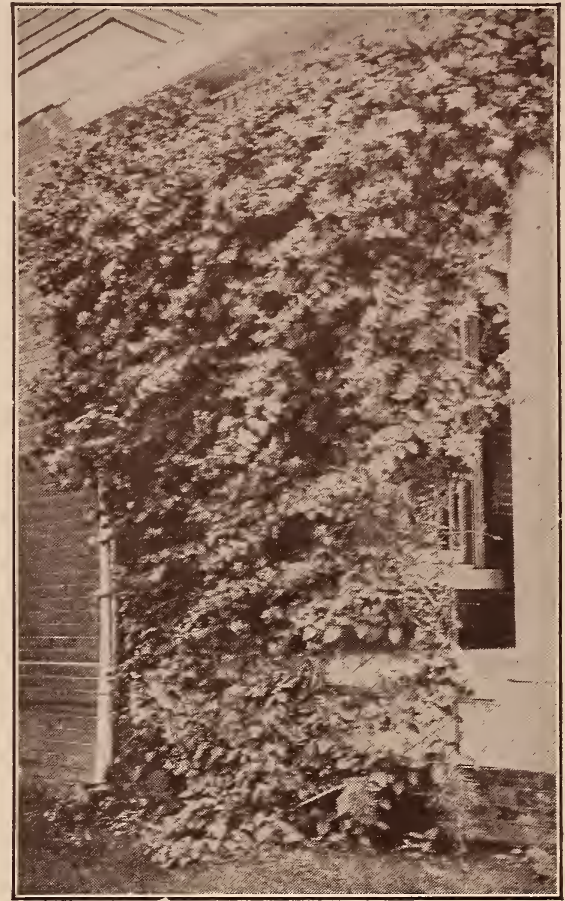

Hall's Honeysuckle

L. Sempervirens-Scarlet Trumpet Honeysuckle.

A strong, rapid grower, producing scarlet, inodorous flowers.

\section{LYCIUM Chinense-Matrimony Vine.}

Sometimes trained as a shrub. Purple flowers and showy fruited. Very vigorous in growth.

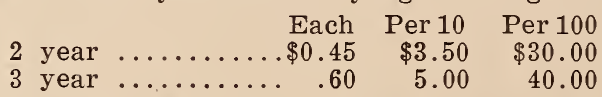

POLYGONUM Auberti-Silver Lace Vine.

$$
\begin{aligned}
& \text { Each Per } 10 \\
& 2 \text { year } \ldots \ldots \ldots \ldots \ldots \ldots \ldots \$ 0.75 \quad \$ 7.00
\end{aligned}
$$

PUERARIA Thunbergiana-Kudzu Vine.

This is the fastest growing vine; has large foliage.

$\begin{array}{rrrr}\text { Each } & \text { Per } 10 & \text { Per } 100 \\ \$ 4 \text { year } \ldots . . . . \$ 0.55 & \$ 4.50 & \$ 40.00\end{array}$

WISTERIA Sinensis-Chinese Purple Wisteria.

Strong climber. Flowers lilac-purple, borne in racemes from four to six inches long.

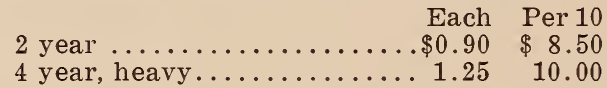

W. Sinensis Alba-Chinese White Wisteria.

Flowers of this variety are pure white and very beautiful.

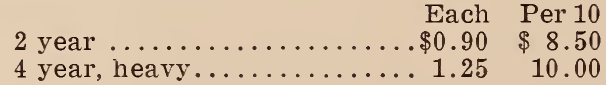




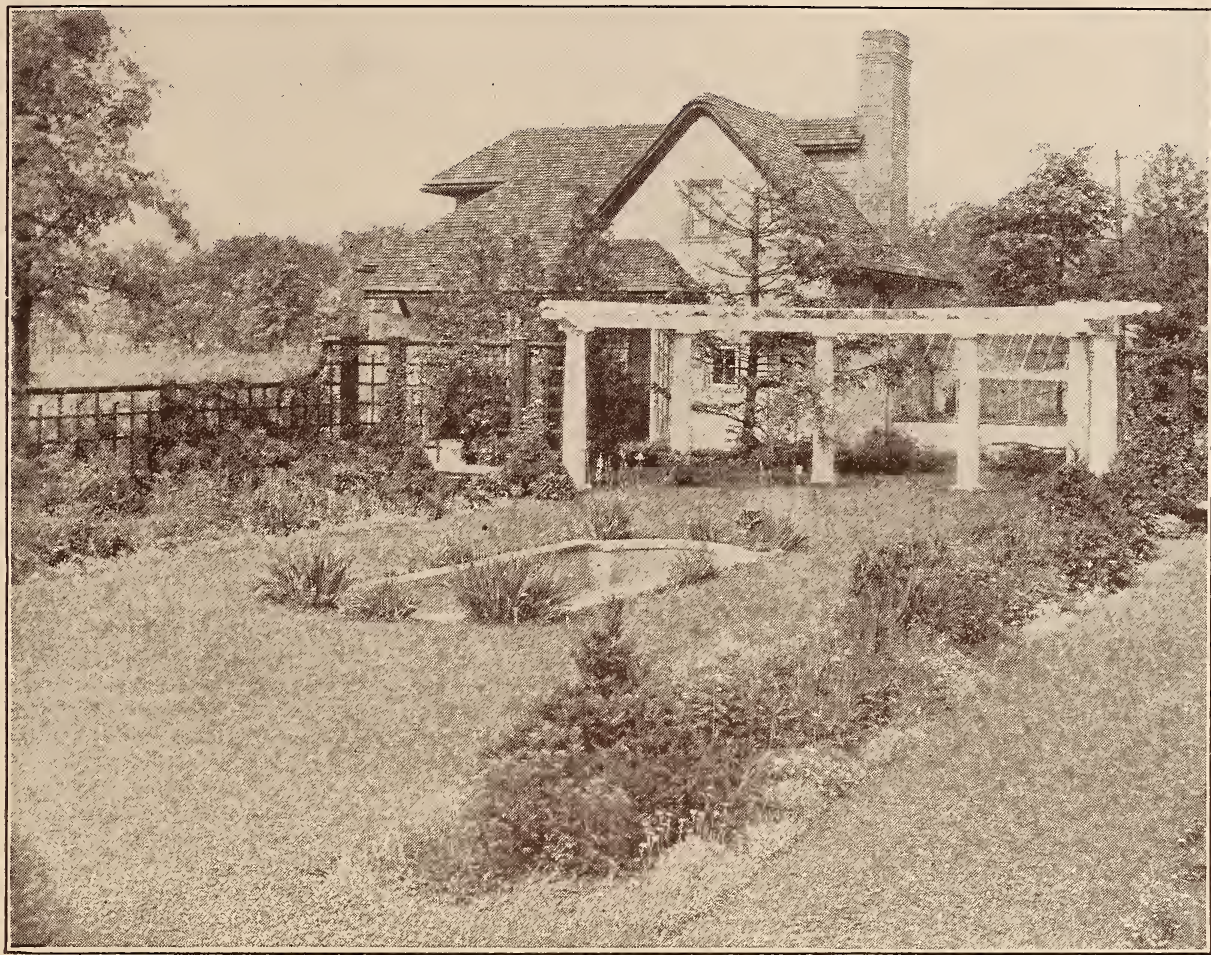

Careful Planting of Shrubs and Perennials Beautifies the Home Grounds

\section{Hardy Perennials}

ACHILLEA Boule de Seige-Milfoil or

\section{Yarrow.}

This variety is an improvement on A. Ptarmica fl. pl. The Pearl. The flowers, although not so large, are of more perfect form with fuller centers. White. Blooms all summer.

Each......\$0.25 Per dozen....\$2.50

\section{A. Eupatorium.}

Grows 3 feet tall, flat heads of brilliant yellow flowers; finely cut foliage. Blooms all summer.

Each......\$0.25 Per dozen.....\$2.50

\section{A. Millifolium Roseum-Rose Flowered}

\section{Yarrow or Rosy Milfoil.}

Rosy-Pink flowers in dense heads on stems 18 inches high; effective on edge of shrubbery or in border.

Each......\$0.25 Per dozen....\$2.50

\section{AGROSTEMMA Coronaria-Rose Champion.}

Purple crimson. Phlox shaped flowers, silvery foliage. June.

Each......\$0.25 Per dozen....\$2.50

\section{ALTHEA Rosea-Hollyhock.}

Grows from four to six feet tall. Are really a necessity to any old fashioned garden. Single and double. White, pink, salmon, yellow, maroon, red. June to August.

Each......\$0.25 Per dozen....\$2.50
ALYSSUM Saxatile Compactum-Dwarf Golden Tuft, Madwort.

Broad masses of bright yellow flowers in early spring. An excellent plant for the rockery or in front of borders.

Each......\$0.25 Per dozen.....\$2.50

\section{ANCHUSA Italica Dropmorei.}

An attractive plant with blue trumpet-shaped flowers in panicles. A continuous bloomer if not allowed to go to seed. Large, rough, glossy foliage.

Each......\$0.25 Per dozen....\$2.50

AQUILEGIA Californica Hybrida-Columbine. A strain of great beauty, being a cross between the native Coerulea and Chrysantha. Flowers much larger than either. Very distinctive in coloring, from creamy-white to intense blue and rosy-purple.

Each......\$0.25 Per dozen.....\$2.50

\section{A. Canadensis-American Columbine.}

The wild Columbine of our native woods. Red and yellow. Very showy and free flowering. Fine for rockery and half-shaded places. Stems 1 to 2 feet.

Each......\$0.25 Per dozen.....\$2.50

\section{A. Chrysantha-Golden Columbine.}

Flowers of golden yellow with long spurs, continuing through June and July.

Each......\$0.25 Per dozen.....\$2.50 


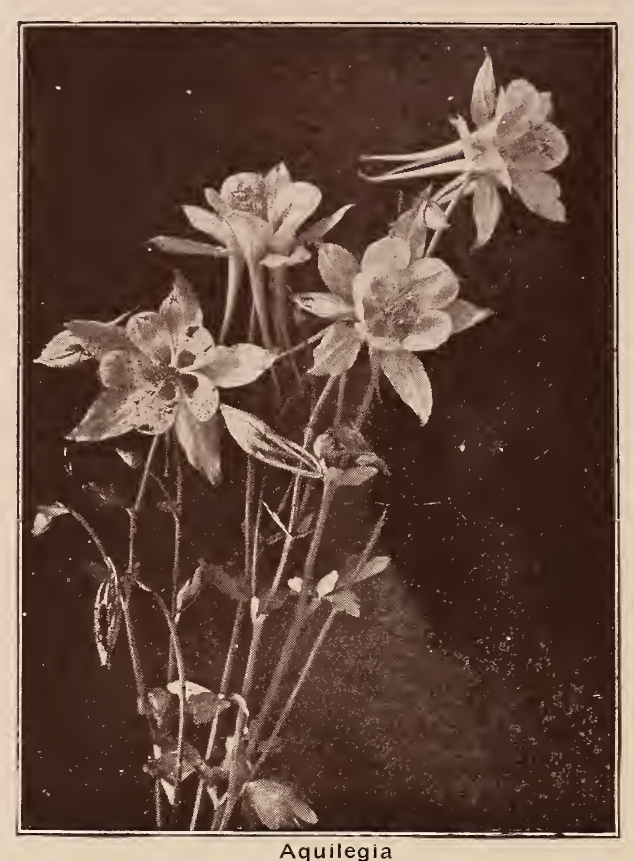

A. Coerulea-Colorado Columbine.

Native in the Rocky Mountains. Deep blue flowers of immense size, sometimes standing as high as two feet.

Each.......\$0.25 Per dozen.....\$2.50

\section{A. Long Spurred Hybrids.}

This strain produces many shades and combinations in purples, blue, red and yellow.

Each.......\$0.25 Per dozen.....\$2.50

\section{A. Nivea Grandiflora.}

White; long spurred.

Each.......\$0.25 Per dozen.....\$2.50

ANTHEMIS Tinctoria.

Handsome finely cut foliage, and large, golden yellow flowers. Produced all summer. Succeeds in poorest soil.

Each.......\$0.25 Per dozen..... \$2.50

\section{ARMERIA Formosa.}

Sea pink or thrift.

Each.......\$0.25 Per dozen.....\$2.50

ASTER Laevis-Michaelmas Daisies, Starwort.

Hardy Asters are unrivaled for their varying forms and bright colors in the perennial border during the autumn months. Wonderful shade of colors lend themselves well for cutting. Very easy to cultivate.

Each.......\$0.25 Per dozen.....\$2.50

\section{A. Nova Anglae-New England Aster.}

Showy pink to purple. Slightly branched and spreading rapidly from the roots. This autumn flowering plant is almost essential in the hardy garden.

Price on all Asters:

Each.......\$0.25 Per dozen.....\$2.50

\section{A. Novae-Anglae Roseum Superbum.}

This is by far the best of the Hardy Asters. Color almost red and a profuse bloomer.
A. Novi-Belgi St. Egwin.

Grows 3 feet high; is of a pleasing pink and very free blooming.

\section{A. Robert Parker.}

Blue. Blooms in September.

\section{A. Mauve Cushion.}

Distinct species, forming a circular cushionlike plant $2 \frac{1}{2}$ feet across and rarely more than 9 inches high. The flowers are of a delicate mauve with silvery white reflex, and are produced in profusion.

A. Mrs. Raynor.

Crimson. Blooms in September.

A. Peter's White.

A. Tartarica.

A distinct, large, bluish-violet color. Very late bloomer. Height about six feet.

\section{BAPTISIA Australis-False Indigo.}

Succeeds in any garden well, growing to a height of about 3 feet. Quite compact and showy. Erect sprays of dark blue flowers in June and July, shaped like sweet peas.

Each.......\$0.35 Per dozen.....\$3.50

\section{BOCCONIA Cordata-Plume Poppy.}

Most tropical looking of our hardy plants. Foliage broad and glaucous. Tall, upright habit, plant terminating in great spikes of whitish flowers. Used for backgrounds or perennial borders.

Each.......\$0.35 Per dozen.....\$3.00

\section{BOLTONIA Asteroides-False Chamomile.}

One of the finest, late flowering perennials. Tall stalks, 4 to 5 feet, surmounted by immense branched heads of flowers, similar to hardy asters. September to October.

Each.......\$0.25 Per dozen.....\$2.50

\section{B. Lastisquamae-Violet Boltonia.}

Clear lavender lilac. Grows vigorously in any soil. September to October.

Each.......\$0.25 Per dozen.....\$2.50

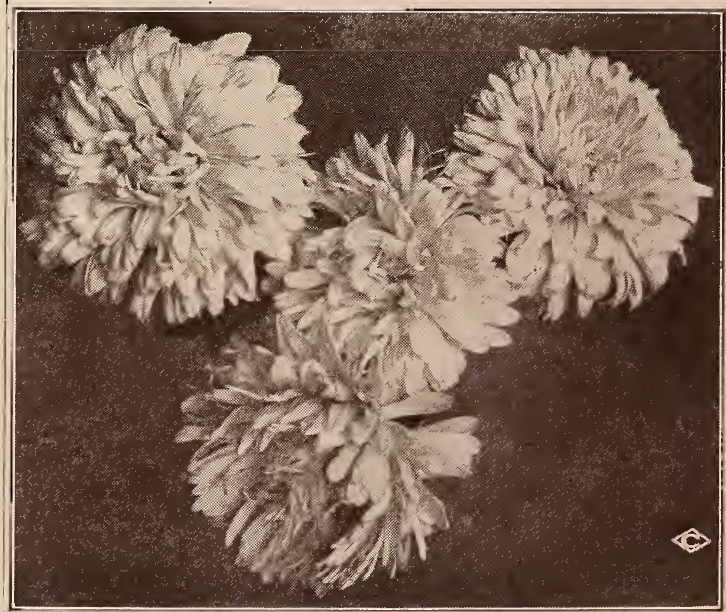

Aster 
CAMPANULA Carpatica-Harebell.

A perfect border edge and low bedding plant. Forms compact tufts of about 9 inches, covered with large erect blue flowers.

Each......\$0.25 Per dozen....\$2.50

C. Pyramidalic (Biennial)-Canterbury Bells. Blue. Blooms in July.

Each......\$0.25 Per dozen....\$2.50

C. Persicifolia.

Blue and white.

Each......\$0.25 Per dozen....\$2.50

CENTUREA Montana-Hardy Cornflower. Large blue flowers on long stems, making them fine for cutting. Hardy, and bloom continuously.

Each......\$0.25 Per dozen....\$2.50

\section{Montana Alba-Hardy Cornflower.}

Same as above excepting the flowers are white.

Each......\$0.25 Per dozen....\$2.50

\section{Gymnocarpa-Dusty Miller.}

Attractive for its grey foliage.

Each......\$0.25 Per dozen.....\$2.50

C. Macrocephala.

Large thistle-like golden-yellow flowers. Useful for cutting and showy in the border.

Each......\$0.25 Per dozen.....\$2.50

\section{CHRYSANTHEMUM-}

There are many named varieties of these beautiful flowers. They grow from one to two feet tall in every shade of crimson, yellow, orange, pink and white, and standing out more prominent when the first killing frosts have swept the garden. A very popular flower. The Pompom and button types are the earliest flow-

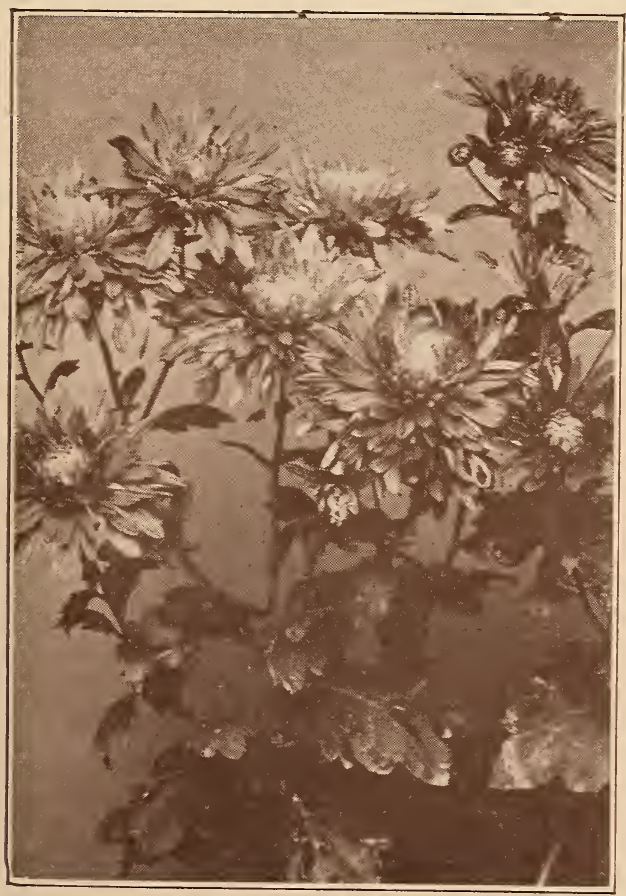

Hardy Chrysanthemums

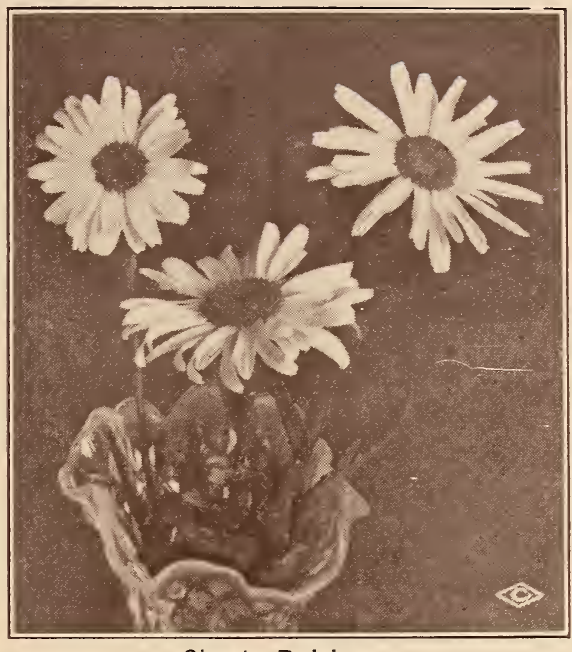

Shasta Daisies

ering, beginning in late August; but all varieties continue into November. All of our Chrysanthemums sell for

Each.......\$0.20 Per dozen.....\$2.00

The following list will offer a wide selection.

Large Flowering Type

Boston-Bronze.

Flamingo-Bronze.

Canariense-Yellow.

Autumn Glow-Rosy Crimson.

Bettie-Pink.

Eldorado-Bright Golden with open center.

Excelsior-Bright Yelow.

Favorite-Buff.

Germania-Straw White.

Oconto-White.

Old Pink-Rose Pink.

St. Illoria-Silver Rose.

\section{Eva-Rose Pink. \\ Anemone Flowering Type}

Button Flowering Type

Inez-Scarlet Bronze and Rose.

Iva-India Red.

Maid of Kent-White.

Little Bob-Bronze.

C. Leucanthemum Hybridum-Shasta Daisy.

A free flowering plant with large showy, daisy-like flowers of white with yellow centers. This is Luther Burbank's great production. July and August.

Each......\$0.25 Per dozen....\$2.50

CONVALLARIA-Lily of the Valley.

These lilies succeed in any shady place and with no care, bear the loveliest and most fragrant of flowers. Should be mulched with manure for increase in size of flowers.

Each, $\$ 0.08$ Per dozen, $\$ 0.75$ Per $100, \$ 5.00$

\section{COREOPSIS Grandiflora.}

One of the most showy of the hardy plants. Has a daisy-like flower, rich and shining yellow. A continuous bloomer, June to September. 3 feet.

Each......\$0.20 Per dozen....\$2.00 


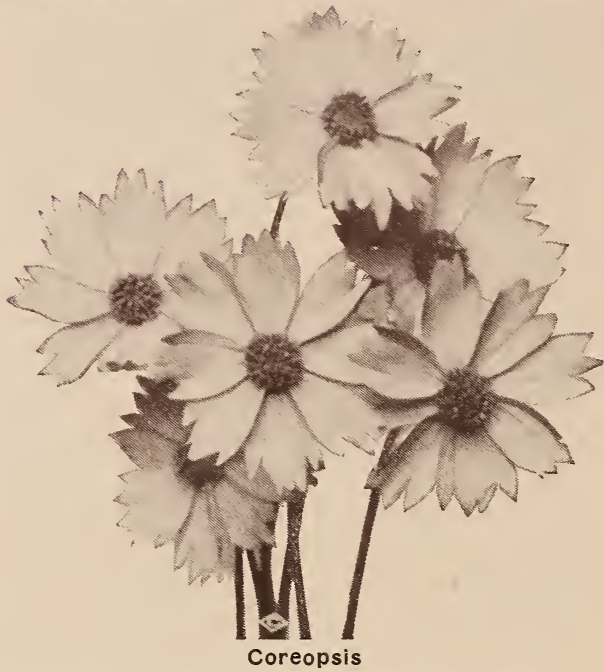

DELPHINIUM Chinensis-Hardy Larkspur.

Highly decorative as a cut flower. Its blue is too powerful for mixed planting, though used in masses, as a contrast with pink, white or a deep even red, it is beautiful. Great uniform spikes of flowers above a sea of sage-green foliage.

Each.......\$0.25 Per dozen.....\$2.50

\section{Chinensis Alba.}

A pure white form of the dwarf species.

Each.......\$0.25 Per dozen.....\$2.50

\section{Belladonna.}

Free blooming. Flowers are a clear turquoise blue.

Each.......\$0.30 Per dozen.... \$3.00

\section{Bellamosa.}

Free blooming. Flowers are a beautiful dark blue.

Each......\$0.30 Per dozen....\$3.00

D. Gold Metal Hybrids.

Of strong, vigorous growth. Shades of blue. June to August.

Each.......\$0.25 Per dozen.....\$2.50

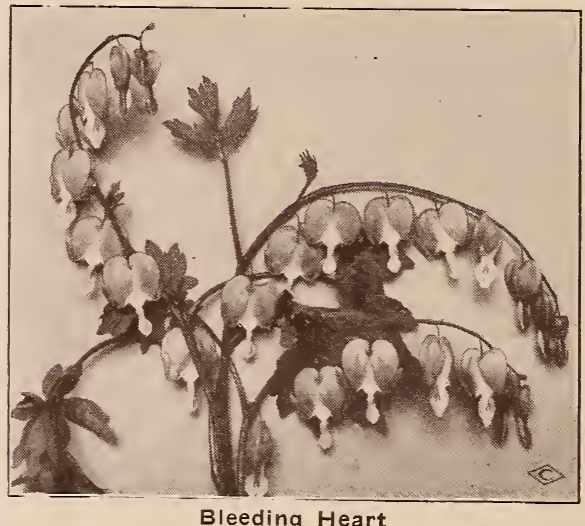

Page Fifty-eight
DIANTHUS Barbatus-Single Sweet William. A well known, attractive, free flowering, hardy perennial. All colors. May and June.

Each.......\$0.25 Per dozen.....\$2.50

D. Hardy Carnation.

Each......... .25 Per dozen..... 2.50

D. Latifolius Artococcineus.

Crimson. All summer. Vigorous.

Each.......\$0.25 Per dozen.....\$2.50

D. Piumarius-Scotch or Clove Pinks.

Bear sweet clove-scented flowers during May and June. Good for edge of hardy border and for cutting. One foot high. Assorted colors. All summer.

Each.......\$0.25 Per dozen.....\$2.50

\section{DICENTRA Spectabilis-Bleeding Heart.}

The old fashioned favorite, with long racemes of graceful, heart-shaped pink flowers. Does well in shade. Blooms in May. Height two feet.

Each.......\$0.60 Per dozen.....\$6.00

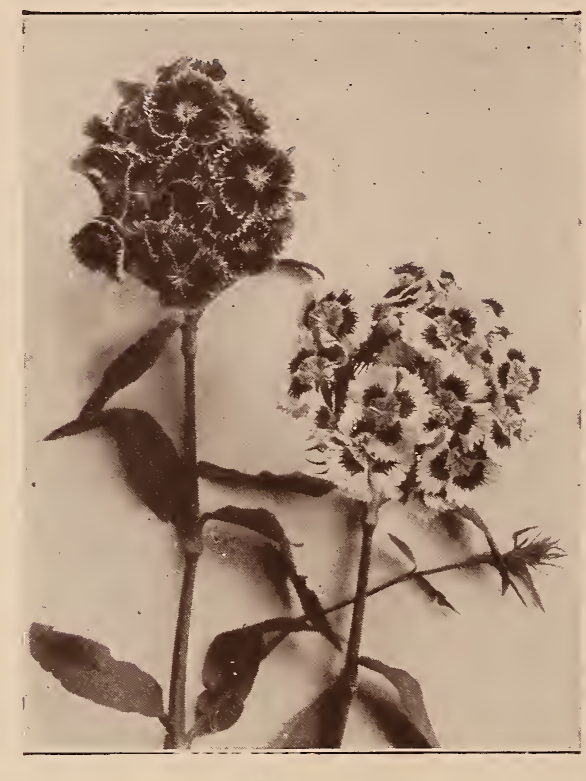

\section{Sweet William}

DIGITALIS Grandifloria-Fox Glove, Yellow. Old fashioned, dignified ańd stately. Good in any garden. Four to six feet high. July to August.

Each........\$0.25 Per dozen.....\$2.50

\section{Gloxinaeflora.}

A beautiful strain of the Gloxinia Foxglove mixed. Blooms in July.

Each.......\$0.25 Per dozen.....\$2.50

\section{Rosea.}

Each.......\$0.25 Per dozen.....\$2.50

\section{ERYNGIUM-Sea Holly.}

Handsome ornamental plants with beautiful blue thistle-like flowers which are produced from July to Sept. Useful to cut for vases or to dry for winter bouquets.

Each........\$0.25 Per dozen.....\$2.50 
EUPATORIUM Ageratoides-Snow Thoroughwort.

Flowers are white. One of the finest hardy perennials for wild gardens, growing three to five feet high; flowering from July to October.

Each.......\$0.25 Per dozen.....\$2.50

\section{E. Coelestinum.}

Blue, and blooms in September and October. Excellent for cutting.

Each.......\$0.25 Per dozen.....\$2.50

EUPHORBIA Cyparissias.

A low growing plant with fine feathery foliage.

Each......\$0.25 Per dozen....\$2.50

FUNKIA Lancifolia-Plantain Lily.

These are among the easiest plants to manage. They are attractive for the border even when not in bloom because of their broad, massive foliage. Succeed in either sun or shade. July.

Each.......\$0.25 Per dozen.....\$2.50

\section{F. Undulata Media Picta.}

Green and white variegated foliage. Purple flowers. Makes fine edging. Blooms in July. Height, two feet.

Each.......\$0.35 Per dozen.....\$3.50

GAILLARDIA Grandifloria-Blanket Flower. Yellow and crimson. Blooms all summer. One of the most popular perennials.

Each.......\$0.20 Per dozen.....\$2.00

\section{HARDY FERNS}

-Asplenium Felix Foemina-Lady Fern. Each.......\$0.50 Per dozen.....\$5.00

-Onicela Struthiopteris-Ostrich Fern. A strong grower.

Each.......\$0.50 Per dozen.....\$5.00

-Osmonda Cinnamoner-Cinnamon Fern. Very beautiful, with erect fronds, drooping at tips. Bright cinnamon colored spores at end of fronds.

Each......\$0.50 Per dozen....\$5.00

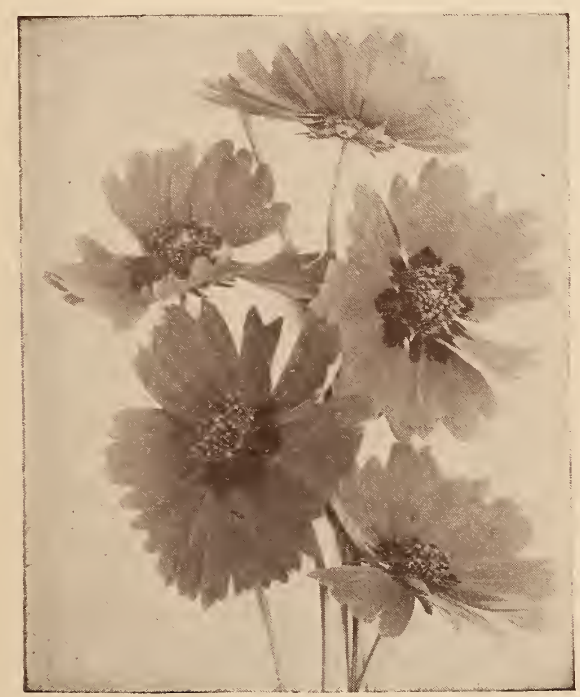

Gaillardia

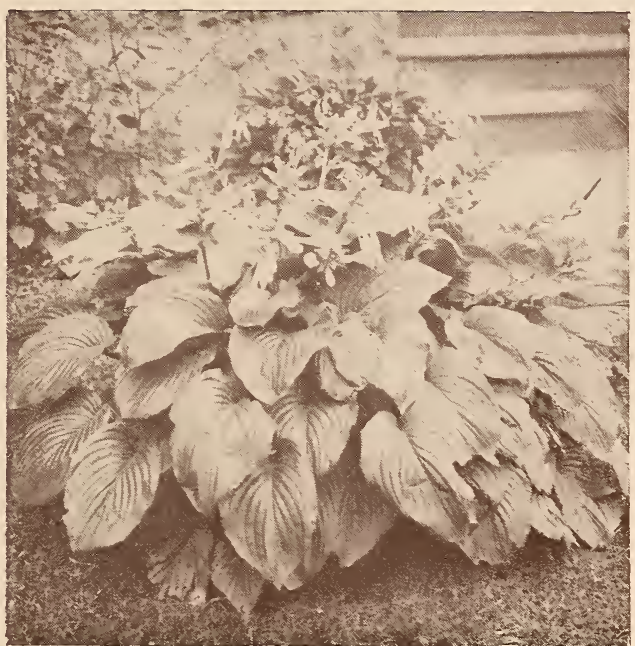

Funkia

\section{-Polystichum Ocrostichoides-Christmas}

Fern.

An evergreen species with deep green divided fronds. Demands a shady position. 12 inches.

Each......\$0.50 Per dozen....\$5.00

\section{ORNAMENTAL GRASSES}

\section{-Erianthus Ravennae-Ravenna Grass.}

Plume or hardy pampas. Closely resembles the Pampas grass. Ten to 12 feet high.

Each.......\$0.50 Per dozen.....\$5.00

Large Clumps, each............\$1.00

\section{-Eulalia Gracillima-Japan Rush.}

Graceful habit, narrow foliage, bright green with silvery mid-rib.

Each.......\$0.35 Per dozen.....\$3.50

-Japonica Variegata.

Long narrow leaves, striped with green and white.

Each.......\$0.35 Per dozen.....\$3.50

\section{-Zebrina-Zebra Grass.}

The long blades of this grass are marked with broad yellow bands across the leaf. Six to seven feet high.

Each.......\$0.50 Per dozen.....\$5.00

\section{-Pennisetum Japonicum-Hardy Fountain}

\section{Grass.}

This variety grows about three feet high, foliage narrow, of bright green, while the cylindrical flowerheads carried well above the foliage are tinged with bronze-purple.

Each.......\$0.35 Per dozen.....\$3.50

Large Clumps, each...........\$1.00

-Phalaris Arundinacea-Ribbon Grass.

Green leaves, striped lengthwise with creamy white.

Each.......\$0.25 Per dozen.....\$2.50 


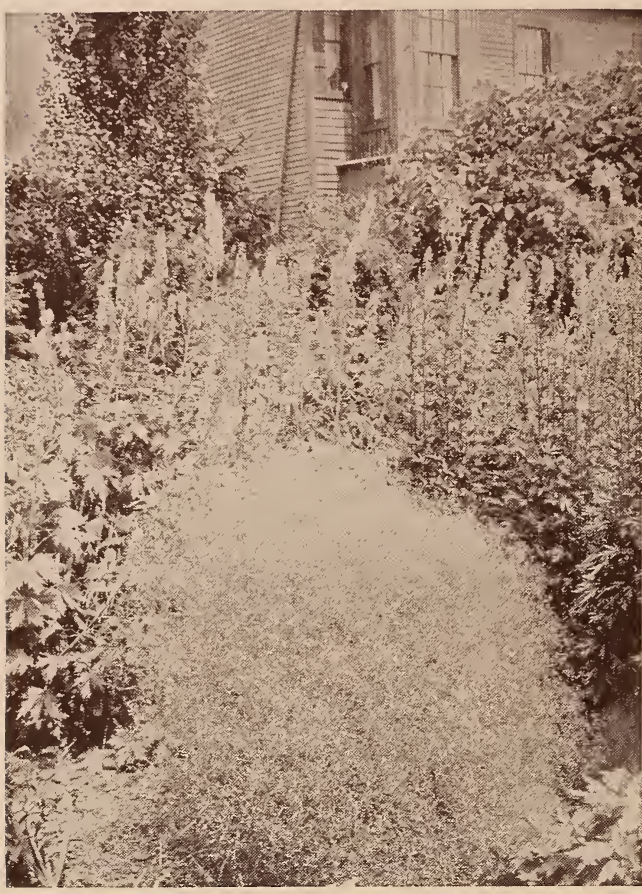

Gypsophila and Delphinium

GYPSOPHILA Paniculata-Baby's Breath.

This possesses a grace not found in any other perennial. Blooms during July and August. Two or three feet high. Flowers are small and pure white.

Each.......\$0.25 Per dozen.....\$2.50

G. Paniculata fl. pl.

Double white.

Each........\$0.35 Per dozen.....\$3.50

HELENIUM Autumnale Superbum.

A brilliant yellow autumn flower, blooming in late summer and fall months. Five to six feet tall.

Each........\$0.25 Per dozen..... \$2.50

HELIANTHUS Maximilliana-Hardy Sun-

\section{flower.}

The finest variety of these flowers have deep yellow, large semi-double, dahlia-like blooms on wiry stems and are very valuable for cut flowers. Others of free growing form have clear yellow flowers borne in immense panicles on long stems. August to September. 4 to 5 feet. Each .......\$0.25 Per dozen.....\$2.50

HELIOPSIS Pitcheriana.

Yellow to orange colored single Zinnia-like flowers blooming profusely through August and September. Rise 3 to 4 feet. Hardy and reliable.

Each......\$0.25 Per dozen.....\$2.50

H. Multiflorus fl. pl.

Double Hardy Sunflower. Large double Dahlia-like golden-yellow flowers in great confusion during July and August.

Each.......\$0.25 Per dozen..... \$2.50

HEMEROCALLIS Flava-Daylily.

An old-fashioned, delightfully fragrant flower, still very popular, the shades running from lemon-yellow to dark orange. Thrives anywhere. June.

Each.......\$0.25 Per dozen.....\$2.50

\section{H. Dumortieri.}

Blooms in June. Orange.

Each.......\$0.20 Per dozen.....\$2.00

\section{H. Fulva.}

Grows from four to five feet high, with trumpet-shaped flowers of a neutral color with darker shadings. August.

Each.......\$0.20 Per dozen.....\$2.00

\section{H. Kwanso.}

Large, double-flowered, with rich, golden bronze flowers.

Each......\$0.25 Per dozen.....\$2.50

H. Thunbergii.

Lemon yellow. July and August

Each.......\$0.25 Per dozen.....\$2.50

HISBISCUS Mallow Marvels.

A robust type of upright habit. Flowers large, in all the richest shades of crimson, pink and white. Mixed colors only.

Each.......\$0.35 Per dozen.....\$3.50

\section{H. Mallow Marvels.}

Separate colors. July and August.

Each.......\$0.50 Per dozen..... \$5.00

IBERIS Sempervirens-Candytuft.

This sort bears innumerable flat heads of pure white flowers. Bloom in August and September.

Each.......\$0.25 Per dozen.....\$2.50

\section{IRIS Cristata-Starry Iris.}

Light blue. Blooms in May and June.

Each........\$0.20 Per dozen.....\$2.00

\section{Florentina.}

White, tinged with blue. Blooms in May and June.

Each.......\$0.20 Per dozen.....\$2.00

\section{Florentina Alba.}

Standards and falls, pearly white. Faint blue cast. Fragrant. Produced early in the season. Excellent for cutting.

Each.......\$0.20 Per dozen.....\$2.00

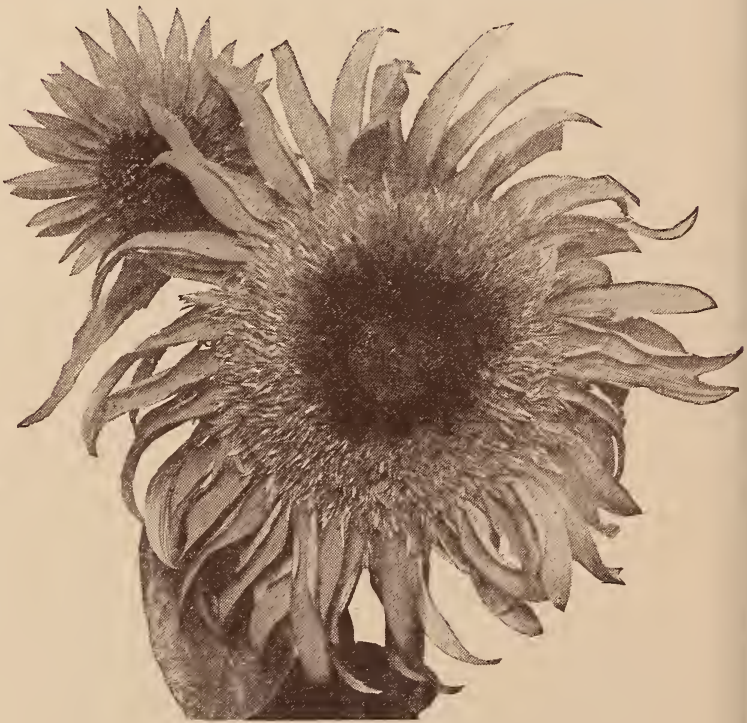

Hardy Sunflower 


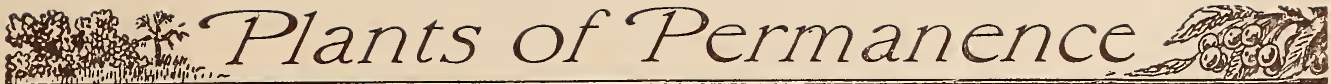

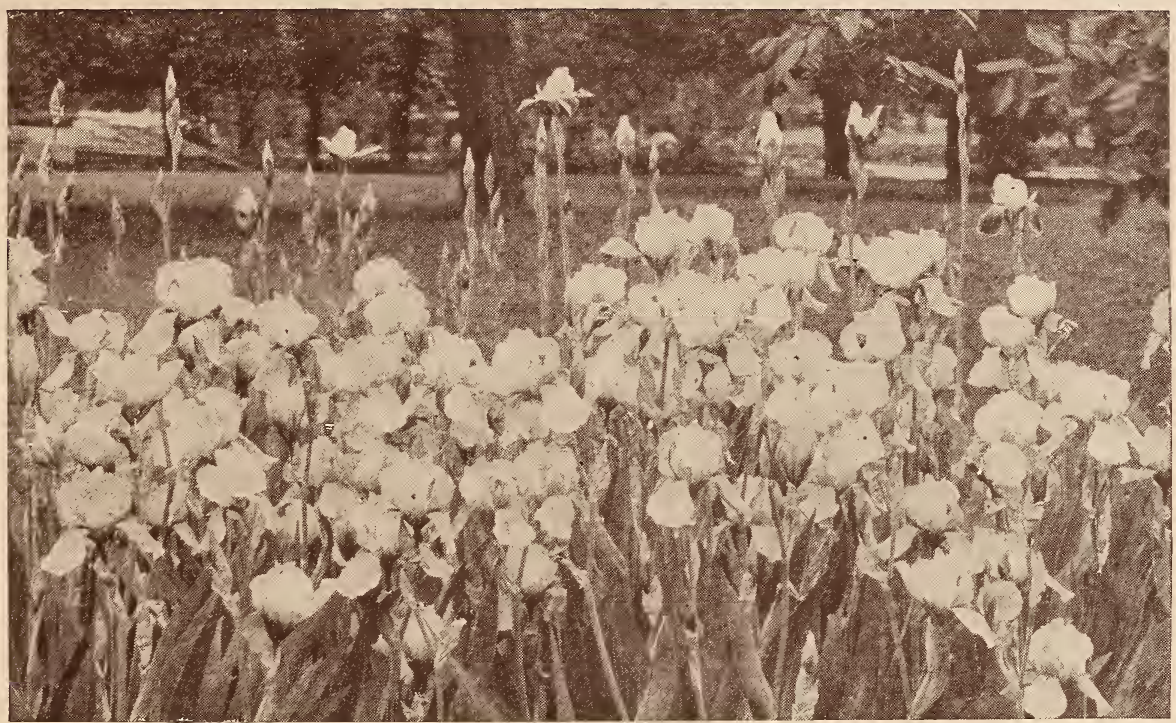

German Iris

\section{Germanica.}

This variety has perhaps the widest range of color, from light to dark purple. The various colors from which to choose may be noted as follows.

Abdul Aziz-Violet Purple.

Each.......\$0.20 Per dozen.....\$2.00

Albert Victor-Soft blue and lavender.

Each.......\$0.25 Per dozen.....\$2.50

\section{Black Prince-}

Caprice-Large rosy red.

Each........\$0.50 Per dozen.....\$5.00

Archiveque-Deep purple velvety violet.

Each.......\$0.50 Per dozen.....\$5.00

Alcazar-Bluish violet bronze veined purple.

Each.......\$0.50 Per dozen.....\$5.00

Celeste-Delicate blue.

Each........\$0.20 Per dozen.....\$2.00

Common Blue Flag-Blue and purple.

Each.......\$0.20 Per dozen.....\$2.00

Gracchus-Lemon yellow and purple.

Each.......\$0.20 Per dozen.....\$2.00

Helge-Lemon-yellow, pearly shading.

Each.......\$0.25 Per dozen.....\$2.50

Halfdan-Creamy white.

Each.......\$0.20 Per dozen.....\$2.00

Her Majesty-Lilac pink.

Each.......\$0.35 Per dozen.....\$3.50

Honorable-Yellow. Brown falls.

Each....... \$0.20 Per dozen.....\$2.00

King of Iris-Lemon-yellow and rich maroon.

Each.......\$0.50 Per dozen.....\$5.00

Isoline-Pinkish buff, russet tinted.

Each........\$0.50 Per dozen.....\$5.00

Kharput-Purple.

Each.......\$0.20 Per dozen.....\$2.00
Louis Meyer-Golden and velvety purple. Each........\$0.40 Per dozen.....\$4.00 Lohengrin-Pink.

Each.......\$0.50 Per dozen.....\$5.00 Juniata-Beautiful clear blue.

Each.......\$0.25 Per dozen.....\$2.50 Lorely-Light yellow and blue.

Each.......\$0.50 Per dozen.....\$5.00 Johan DeWit-Late purple.

Each.......\$0.40 Per dozen.....\$4.00 Mad. Chereau-White, tinged with blue.

Each........\$0.20 Per dozen.....\$2.00 Marion-Lavender and white.

Each.......\$0.20 Per dozen.....\$2.00

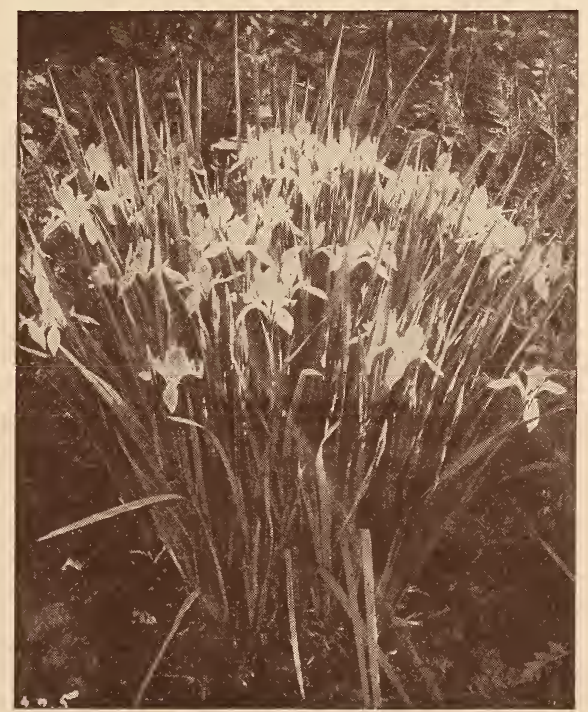

Japanese Iris 


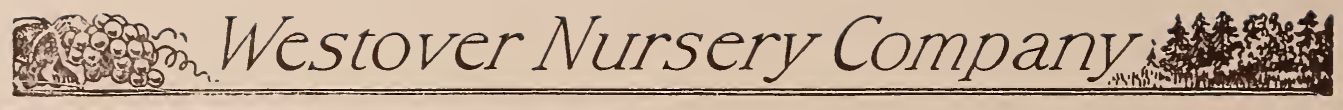

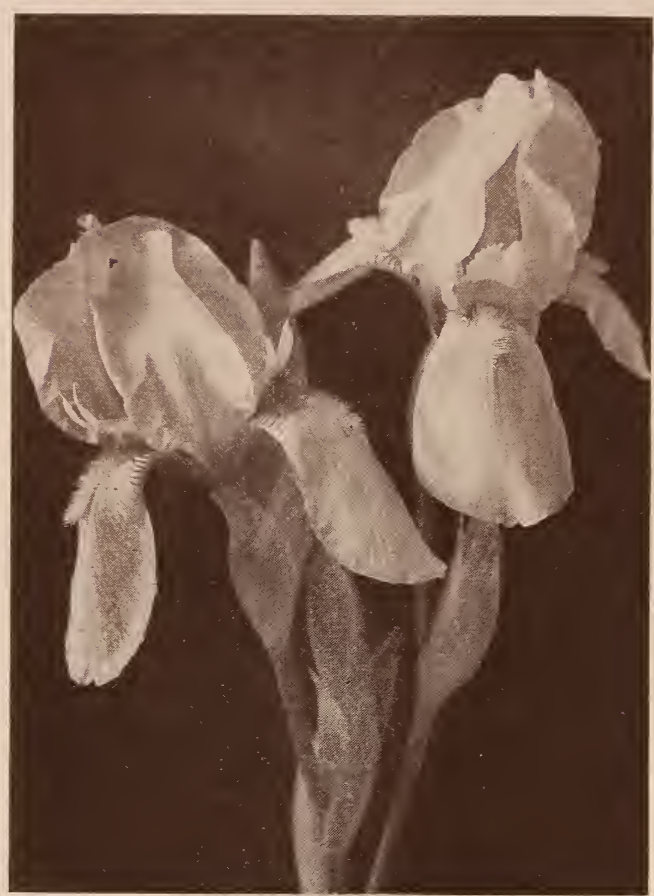

Iris

Mrs. H. Darwin-Pure white.

Each.......\$0.20 Per dozen.....\$2.00

Mrs. Allan Gray-Lavender pink.

Each......\$0.35 Per dozen....\$3.50

Oriflame-Blue and violet purple.

Each......\$0.40 Per dozen....\$4.00

Monsignor-Violet veined purple.

Each.......\$0.50 Per dozen.....\$5.00

Parisensis-Dark blue.

Each......\$0.20 Per dozen....\$2.00

Plumeri-Coppery rose and velvety claret.

Each.......\$0.20 Per dozen.....\$2.00

Princess of Wales-Pearly white.

Each.......\$0.25 Per dozen....\$2.50

Pallida Dalmatica-Lavender.

Each.......\$0.25 Per dozen.....\$2.50

Pallida Speciosa-Light blue.

Each.......\$0.20 Per dozen.....\$2.00

Leonidas-Mauve.

Each.......\$0.40 Per dozen....\$\$4.00

Mandraliscae-Lavender-purple.

Each.......\$0.40 Per dozen.....\$4.00

Perfection-Light blue and violet black.

Each.......\$0.25 Per dozen....\$2.50

Pallida-Queen of May-Lavender pink.

Each.......\$0.50 Per dozen.....\$5.00

Princess Victoria Louise-Sulphur yellow.

Each.......\$0.40 Per dozen....\$4.00

Purple King-Royal purple.

Each.......\$0.20 Per dozen.....\$2.00

Rose Unique-Rose pink.

Each......\$\$0.50 Per dozen....\$5.00

Sappho-Yellow flushed lavender.

Each......\$0.35 Per dozen....\$3.50
Sherwin Wright-Golden yelow.

Each......\$\$0.50 Per dozen.....\$5.00

Silver King-Silvery white.

Each.......\$0.25 Per dozen.....\$2.50

Tamerlan-Lavender violet.

Each......\$\$0.35 Per dozen.....\$3.50

Thorbeck-Violet blue.

Each.......\$0.40 Per dozen....\$4.00

Walhalla-Lavender and wine red.

Each.......\$0.20 Per dozen.....\$2.00

Wyomissing-White and soft rose.

Each......\$0.25 Per dozen....\$2.50

1. Kaempferi-Japanese Iris.

White, purple, blue and pink. The Japanese

varieties follow the German in blooming.

Each ......\$0.50 Per dozen....\$5.00

I. Pumila Alba.

These varieties offer fine edging for beds and borders. Bloom early in April.

Each.......\$0.20 Per dozen.....\$2.00

\section{Pumila Violacea.}

Violet. Blooms in April. Dwarf.

Each.......\$0.20 Per dozen.....\$2.00

I. Siberica-Siberian Iris.

Flowers of brilliant blue. Small inner petals

long and narrow, curving together at apex.

Each......\$0.20 Per dozen....\$\$2.00

1. Siberica Alba.

White Siberian. Blooms in June.

Each.......\$0.20 Per dozen....\$2.00

LATHYRUS Latifolius-Perennial Pea.

Pink to red. Blooms from June to August.

Each.......\$0.30 Per dozen.....\$3.00

LIATRIS Spicata-Blazing Star or Gay Feather.

Very attractive as well as odd. Blooms in mid-summer with long narrow spikes of rich purple flowers. The flowers are an attraction for butterflies.

Each......\$0.25 Per dozen....\$2.50

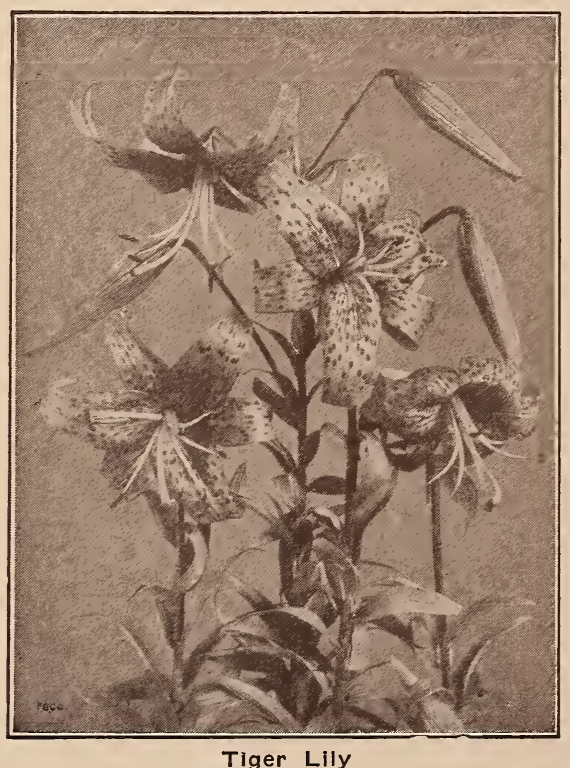


LILLIUM Tigrinum Splendens-Tiger Lily.

Immense salmon-red flowers, aotted with crimson-brown. Still often found about old places. Very hardy. July to September.

Each......\$0.50 Per dozen....\$5.00

L. Candium-Madonna Lily.

A delicately fragrant, pure waxy white lily of easy culture.

Each......\$0.50 Per dozen....\$5.00

\section{Auratum.}

Large, graceful flowers of six petals. Ivory white. Thickly studded with chocolate-crimson spots and striped through the center a goldenyellow.

Each.....\$0.60 Per dozen....\$6.00

L. Rubrum.

White, heavily spotted with rich, rosy crimson spots.

Each......\$0.60 Per dozen....\$6.00

\section{LINUM Perenne-Flax.}

Desirable for border or rockery. Two feet high. Light, graceful foliage and large blue, flowers all summer. One foot to 18 inches high. Each.......\$0.20 Per dozen.....\$2.00

LYCHNIS Chalcedonica-Maltese or Jerusalum Cross.

One of the most brilliant, hardy border flowers. Dark green foliage, hairy and narrow. Blossoms all summer.

Each......\$0.25 Per dozen....\$2.50

LYSMACHIA Clethroides.

Long, recurved spikes of pure white flowers, from July to September. A desirable variety. Each.......\$0.25 Per dozen.....\$2.50

L. Nummularia-Creeping Jenny or Moneywort.

Valuable for planting under trees or shrubs where grass will not grow.

Each......\$0.20 Per dozen....\$2.00

LYTHRUM Roseum Superbum-Loose Strife. A strong growing plant three to four feet high. Produces large spikes of rose-colored flowers from July to August.

Each......\$0.50 Per dozen....\$5.00

MATRICARIA Capensis. fl. pl.-Double White Feverfew.

Blooms in May.

Each.......\$0.25 Per dozen....\$2.50

MERTENSIA Virginica-Blue Bells.

Purplish blue. Blooms from March to May.

Each......\$0.25 Per dozen....\$2.50

MINT Peppermint and Spearmint.

Each......\$\$0.15 Per dozen....\$1.50

MONORDA Didyma-Cambridge Scarlet

Bergamot.

Red. Blooms from July to September.

Each......\$0.25 Per dozen....\$2.50

MYOSOTIS Palustris-Forget-Me-Not.

The large spring-flowering sort with intense sky-blue flowers, bright and attractive.

Each.......\$0.20 Per dozen.....\$2.00

PACHYSANDRA Terminalis-Japanese Spurge.

A low trailing, dense evergreen with glossy green foliage. An excellent ground cover and entirely hardy.

Each......\$0.25 Per dozen....\$2.50

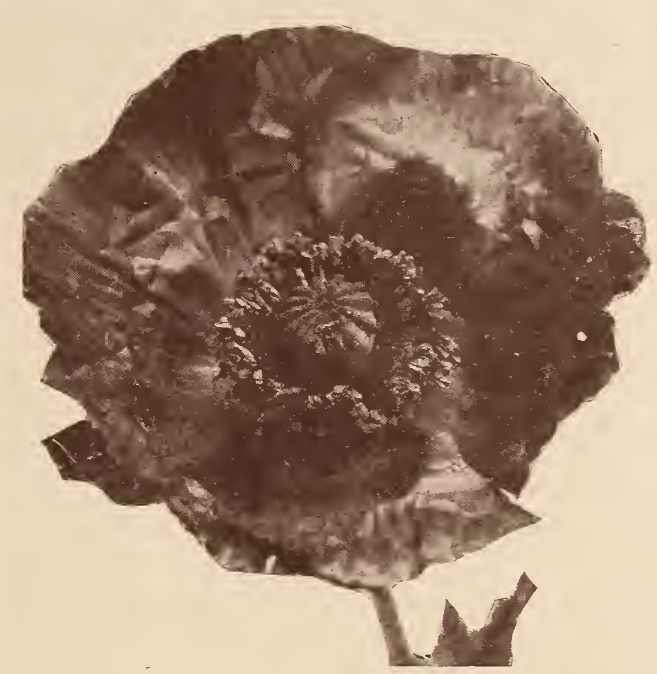

Oriental Poppy

PAPAVER Orientale-Oriental Poppy.

A fiery orange scarlet variety of this genius. Height 3 to $3 \frac{1}{2}$ feet. Blooms in May and June. Each......\$0.30 Per dozen....\$2.50

P. Mrs. Perry.

Pink.

Each......\$0.35 Per dozen....\$4.00

PAEONIA Alexandra Dumas.

Violet rose, crown cream white color of narrow petals, mingled with the wide center petals, fragrant.

Price on all Paeonias except where noted: Each......\$0.75 Per dozen....\$7.50

P. Coronne d'Orr.

White and cream. Beautiful, fragrant, pure white flowers of superb form. Strong grower. Each......\$0.80 Per dozen....\$8.00

P. Dorchester.

Hydrangea pink. Large compact rose type; fragrant.

Each......\$\$0.80 Per dozen....\$8.00

P. Albatre.

Milk-white tinged Lilac. Large compact rose type, free bloomer, vigorous grower.

Each......\$0.90 Per dozen.....\$9.00

P. Avalanche.

Creamy-white, flecked with carmine. Large compact crown type. Fragrant, strong growth.

Each......\$\$0.90 Per dozen....\$9.00

P. Asa Gray.

Large semi-rose type. pale Lilac sprinkled with minute dots of deeper lilac. Fragrant and of good habit.

Each......\$1.00 Per dozen....\$10.00

\section{P. Boule De Niege.}

Very large globular, compact, semi-rose type. Milk-white guards and center flecked crimson. Tall erect, free bloomer.

P. Charles Gosselyn.

Beautiful flesh-white with sulphur center. 
P. Charlemagne.

Very compact, large globular-rose type. Lilacwhite, with a slight blush center. Fragrant and free bloomer.

\section{P. Dr. Bretonneau.}

Pale Lilac-Rose, center tipped, creamy-white; fragrant, vigorous grower and free bloomer.

P. Delachei.

Large rose type, violet-crimson, slightly tipped silver. Strong, erect and free bloomer.

Each.......\$0.90 Per dozen.....\$9.00

\section{P. Edward VII.}

A beautiful clear bright red.

Each.......\$0.90 Per dozen.... \$9.00

\section{P. Emperor Nicholas.}

Medium size, semi-rose type. Dark carminerose.

Each......\$0..90 Per dozen.....\$9.00

P. Floral Treasure.

Large showy, pale Lilac-rose.

P. Golden Harvest.

Informal rose-type. Guards pale lilac-rose, center creamy-white, dwarf habit, fragrant and free bloomer.

\section{P. Jacqueminot.}

This is a late red, the color of a Jack Rose.

Each.......\$0.90 Per dozen.....\$9.00

\section{P. Jeanne D'Arc.}

Large globular. Guards and center pale lilac-rose, collar cream-white shaded with sulphur. Strong medium height and free bloomer.

\section{P. La Rosarie.}

Large semi-double pond-lily type, sulphurwhite, showing yellow stamens. A very decorative variety.

\section{P. La Tendresse.}

Large, compact, flat rose-type. Uniform milk-white guards slightly flecked with crimson. Fragrant, tall, strong and free bloomer.

Each......\$\$0.90 Per dozen.....\$9.00

\section{P. La Tulipe.}

Lilac white, outer petals striped with crimson. Large, flat, rose-type, fragrant, very tall, strong growth.

\section{P. Marie.}

Lilac-white, fading to milk white. Compact rose-type, fragrant and very tall.

\section{P. Marie Antoinette.}

Mid-season, large, single, deep pink.

\section{P. Marie Lemoine.}

Pure white with cream-white center, large compact rose-type. Fragrant, medium height and strong stems.

Each......\$0.90 Per dozen....\$9.00

P. Marie Stuart.

Very large, delicate lilac-pink. One of the rery best varieties.

Each......\$0.90 Per dozen....\$9.00

P. Meissonier.

Medium size bomb, developing a crown with age. Brilliant purple-red, tall, fragrant, and free bloomer.

Each......\$0.90 Per dozen.....\$9.00

P. Mme. De Verneville.

Large. very full bomb. Pure white with prominent carmine flecks. Fragrant, medium height, extra free bloomer.

P. Mme. Brevier.

Mid-season, flesh pinik. A free bloomer.

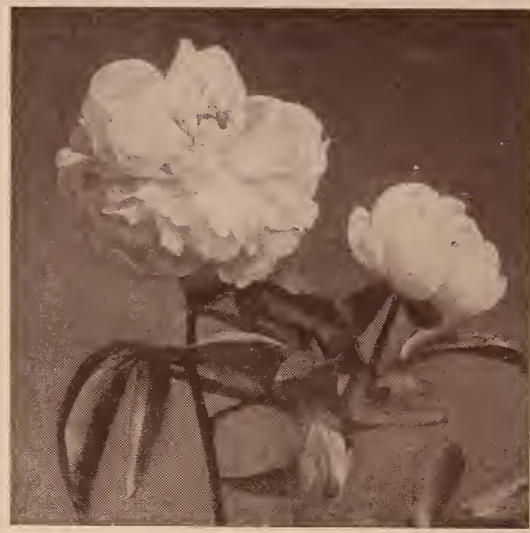

Peony

P. Mme. De Hour.

Very large blooms, soft carmine-pink, silvery reflex.

Each......\$0.90 Per dozen....\$9.00

P. Mme. Boulanger.

Very large full bloom; glossy soft pink, shaded lilac. Silvery flesh border. Very fine. Each......\$1.00 Per dozen.....\$10.00

P. M. Jules Elie.

A very fine large variety, pale lilac-rose in color.

Each......\$1.00 Per dozen....\$10.00

P. Mt. Blanc.

Very large, compact globular rose-type. Milk white center slightly tinted rose. Fragrant, strong stems and free bloomer.

P. Pres. McKinley.

Very large solferino red.

Each.......\$0.90 Per dozen.....\$9.00

\section{P. Queen Victoria.}

Large globular, milk-white guards, tinted flesh center. Cream-white with crimson spots. Fragrant, medium height and free bloomer.

P. Virgo Marie.

Uniform, pure ivory-white. Medium height and fragrant.

\section{P. Duchesse de Nemours.}

Cup shaped, fragrant flower with guard petals of pure white and lemon yellow center. Strong grower and free bloomer.

\section{P. Edulus Superba.}

The old-fashioned full variety. Large, fragrant, loose double flowers of mauve pink. Early bloomer. One of the best commercial varieties.

\section{P. Felix Crousse.}

Dark red. Medium to large. Globular shape. Brilliant red and fragrant.

Each.......\$1.00 Per dozen....\$10.00

\section{P. Festiva Maxima.}

Finest early white. Very large and full. Rose type. Very tall. Popular for cut flowers. Early.

\section{P. Fragrans.}

Deep pink.

P. Humei.

Cherry-pink with silver lip. Highly scented. Each......\$0.80 Per dozen....\$8.00 


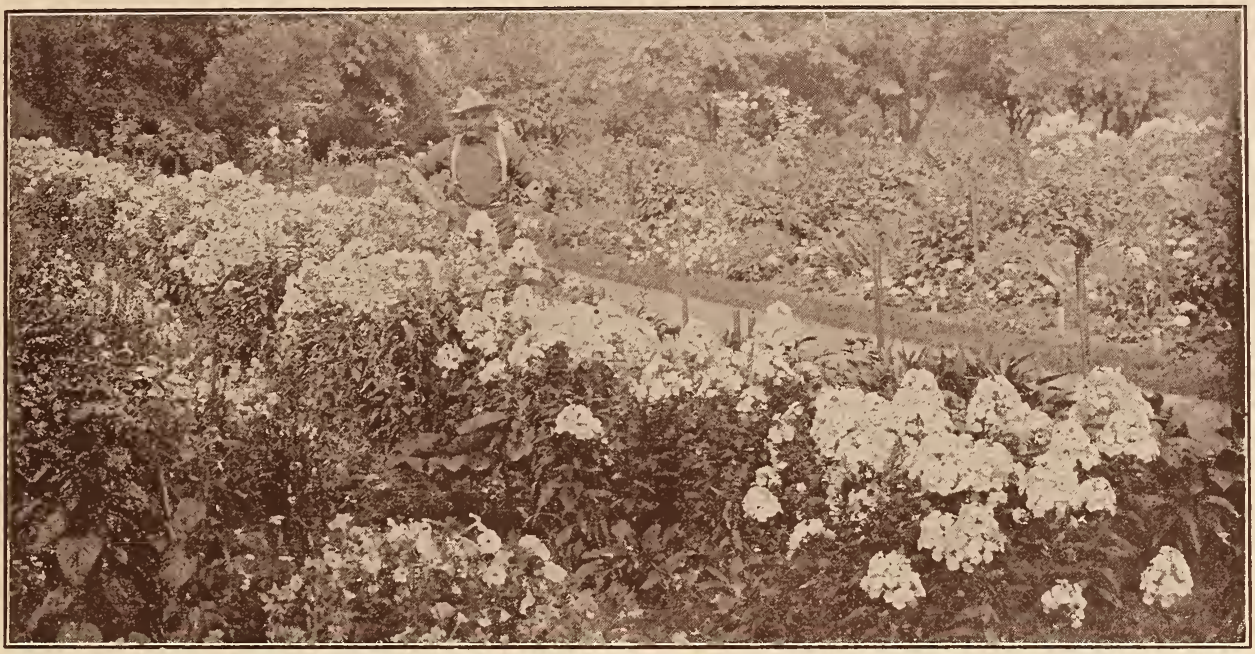

Phlox as a Border

P. L' Indispensable. Creamy white.

P. Jules Calot. Bright pink.

P. Oficinalis Rubra.

Early red. The old-fashioned garden peony and the first of the family to bloom.

Each......\$1.00 Per dozen....\$10.00

P. Rubra Superba.

Brilliant, deep cerise-pink. Blooms compact and perfectly formed. Long stems. Blooms mid-season.

Each.......\$0.90 Per dozen....\$9.00

\section{P. Undivided Clumps.}

Each..............\$3.75 to $\$ 7.50$

PENTSTEMON Barbatus Torreyii-Coral Red Beard Tongue.

Most useful and showy of perennials. Spikes of deep bright scarlet or coral red flowers. Fine for cutting, and effective border plant.

Each.......\$0.25 Per dozen.....\$2.50

PHLOX Divaricata.

Lavender. April and May.

Prices on all Phlox:

Each.......\$0.25 Per dozen.....\$2.50

P. Canadensis.

Blue. Blooms in May.

P. Maculata.

Purplish red. May and June.

P. Paniculata.

Athis-Salmon pink.

B. Compte-Purple. Rich, satiny amaran-

thine flowers.

Baron Von Dedum-Brilliant orange red.

Champs Elysee-Bright rose magenta.

Eclaireur-Large flowers of carmen-violetred with pink center.

Etna-Orange red.

Henri Murgher-White with magenta eye.

Jeanne D' Arc-White.

Jules Sandeau-Pink.

Mrs. Charles Door-A beautiful shade of lavender.

Mrs. Jenkins-White.

La Vague-Lavender pink.
Pantheon-Rose pink.

R. P. Struthers-Cherry red suffused with salmon. Very showy.

Rheinlander-Large salmon pink, intensified by a distinct claret-red eye.

Rynstroom-A lively shade of rose-pink, very large.

Thor-A beautiful deep, salmon-pink suffused with scarlet glow.

W. O. Wijers-Pink, with deep eye.

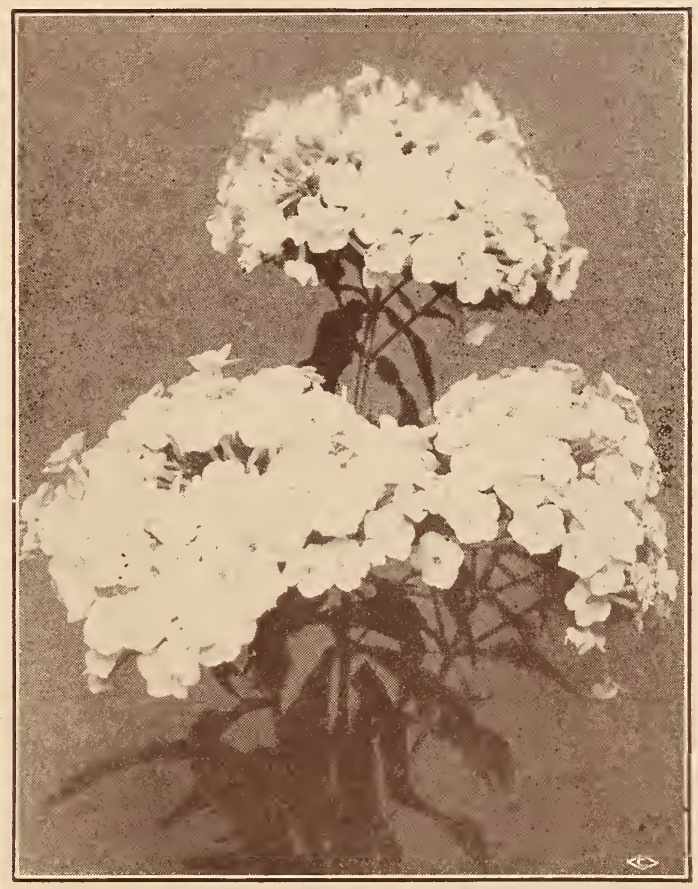

Phlox 


\section{Westover Nursery Company}

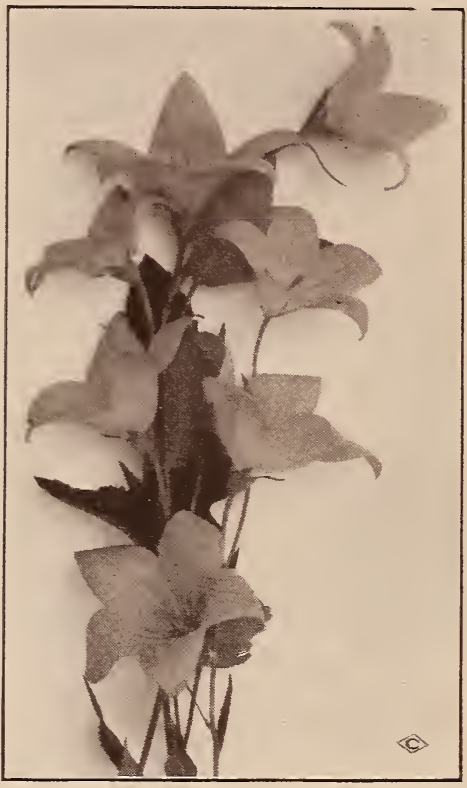

Platycodon

\section{P. Sublata Alba.}

Moss or Mountain pink. White. April and May.

P. Sublata Rosea.

Pink. Blooming in April and May.

P. Stellaria-Creeping Phlox. Pink.

P. Suffruticosa-Miss Lingard.

Pearly white. The best in cultivation.

PHYSALIS Francheti-Chinese Lantern Plant. An ornamental variety forming dense bushes 2 feet high, producing orange-scarlet, lanternlike fruits, which when cut will last all winter. Each.......\$0.30 Per dozen.....\$3.00

\section{PHYSOSTEGIA Virginica-False Dragon} Head.

Spikes of bright but soft pink, delicate tubu-

lar flowers. August. Each.......\$0.25 Per dozen....\$2.50

P. Virginica Nana.

Same as above excepting that it is a very dwarf growing variety. Pink.

Each......\$0.25 Per dozen.....\$2.50

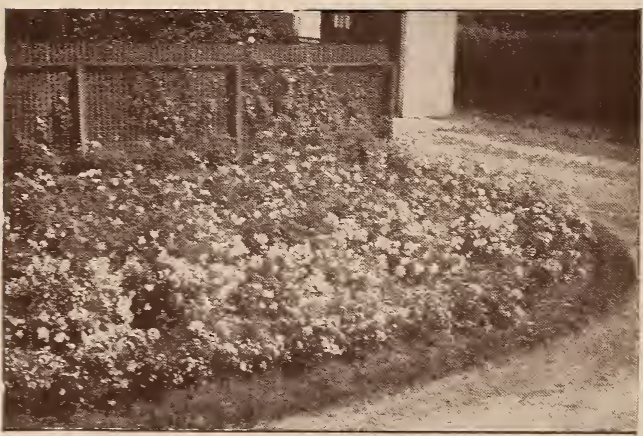

Page Sixty-six
PLATYCODON Grandiflorea-Balloon

\section{Flower.}

Deep blue, cupped; star-shaped flowers

Each......\$0.25 Per dozen....\$2.50

PLUMBAGO Larpente-Leadwort.

Blue. Blooms August to October.

Each......\$0.25 Per dozen.....\$2.50

PYRETHRUM Roseum-Painted Daisy.

Easy to grow. Loves the sun. May to June.

Each.......\$0.25 Per dozen.....\$2.50

P. Uliginosum-Giant Daisy.

Grows from three to four feet high and is covered with large, daisy-like flowers. July to september.

Each.......\$0.25 Per dozen.....\$2.50

RANUNCULUS Acris, Fl. Pl-Double Crowfoot.

Yellow. Blooms in May and June.

Each.......\$0.25 Per dozen.....\$2.50

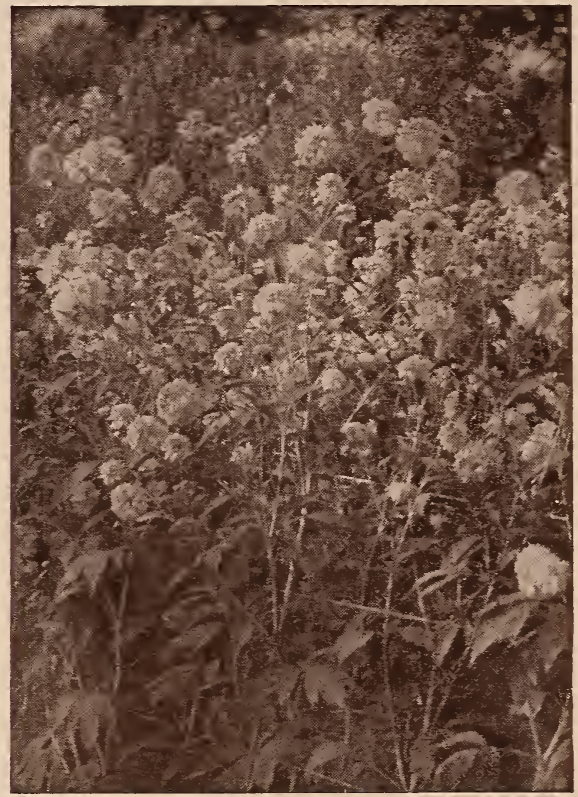

Golden Glow

RUDBECKIA Laciniata-Golden Glow.

Robust grower. Five to six feet high. Produces a mass of golden-yellow flowers from July to September.

Each.......\$0.25 Per dozen....\$2.50

R. Newmani.

Dark orange-yellow flowers, borne on stiff wiry stems. Flowers from July to September.

Each.......\$0.25 Per dozen.....\$2.50

R. Purpurea-Purple Coneflower.

Produces all summer, large, showy, reddishpurple flowers about four inches across.

Each......\$ $\$ 0.25$ Per dozen....\$2.50

SALVIA Azurea-Meadow Sage.

A native species, growing from 3 to 4 feet high, producing pretty sky blue flowers. August and September.

Each.......\$0.25 Per dozen.....\$2.50

S. Pratensis.

Showy spikes of deep blue flowers. Very pretiy foliage, 2 to 3 feet high. June to September.

Each......\$0.25 Per dozen.... \$2.50 
SEDUM Maximowiczii-Stone Crop.

Yellow. Valuable as a late blooming plant. Fine border plant and one of the best for foli2ge. July and August.

Price on all Sedum except where noted:

Each.......\$0.25 Per dozen....\$2.50

\section{S. Ewersi.}

Gray foliage.

\section{S. Spectabilis.}

One of the prettiest of the tall growing speeies. Pink. Blooms in August and September.

S. Spectabilis, Brilliant.

Crimson.

S. Acre-Golden Moss.

A dwarf variety much used for covering graves. Foliage green. Flowers bright yellow. Each.......\$0.20 Per dozen.....\$2.00

S. Sarmentosum-Dwarf.

S. Stolonifera.

S. Spurium Coccineum.

Rosy crimson.

SEMPERVIVUM-House Leak.

Curious and interesting plants forming rosettes of succulent leaves. Good for rockeries, dry banks, carpet bedding or walls.

Each......\$0.50 Per dozen....\$5.00

STATICE Latifolia-Sea Lavender.

Grows 15 to 18 inches high in clumps of thick leathery foliage, with loose panicles of tiny delicate blue flowers in heads 18 inches or more across.

Each......\$0.25 Per dozen....\$2.50

STACHYS Lanata-Wound Wort.

Each......\$0.25 Per dozen.....\$2.50

STOKESIA Syanea-Stokes Aster.

A native plant 18 inches high, bearing flowers freely from early June until September. Handsome lavender-blue.

Each.......\$0.25 Per dozen.....\$2.50

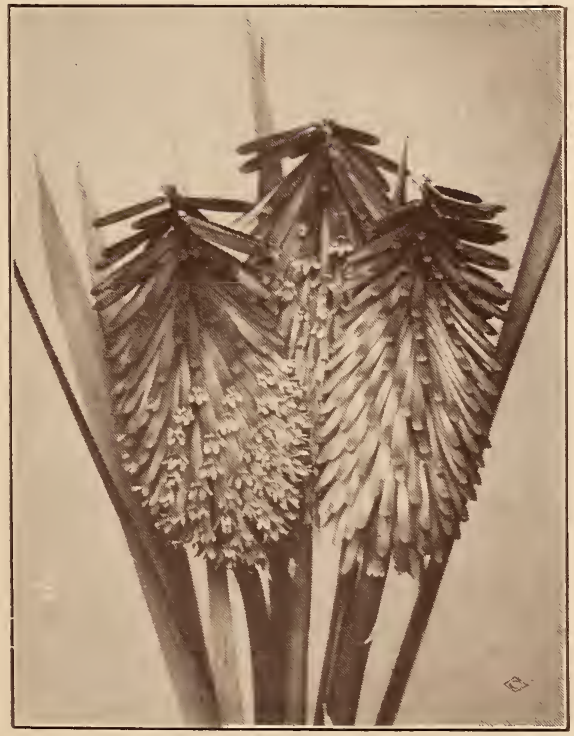

Tritoma

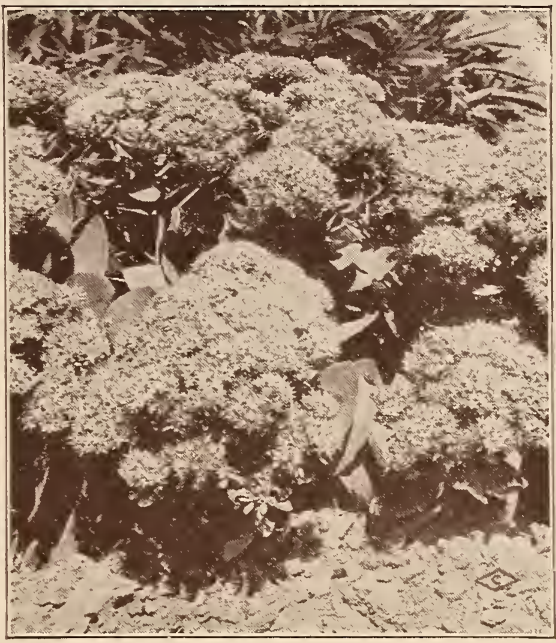

Sedum

TRILLIUM Grandiflorium-Snow Trillium.

Usually large white flowers. Very handsome. Excellent for shady positions.

Each.......\$0.10 Per dozen....\$1.00

TRITOMA Pfitzeri-Red Hot Poker Plant or Torch Lily.

Coral. Vies with the canna for attractiveness and brilliancy.

Each......\$0.30 Per dozen....\$3.00

VALERIANA Coccinea.

Blooms all summer. Produces snowy heads of rose tinted white flowers.

Each.......\$0.25 Per dozen....\$2.50

VERONICA Longifolia Subsessiles-

Speedwell.

Blue. August to October. The showiest and best of all the Speedwells. Forms a bushy plant two to three feet high with long, dense spikes of deep blue flowers.

Prices on all Veronicas:

Each.......\$0.25 Per dozen.....\$2.50

V. Amethystina.

Blue. Blooms in June and July.

V. Spicata-Spike Speedwell.

Long spikes of small violet-blue flowers, 18 inches. June to August.

V. Longifolia.

Blue. June to August.

VINCA Minor-Myrtle.

An excellent dwarf evergreen used extensively in carpeting the ground, under shrubs or trees or on graveyards. Thrives where it is too shady for other plants to live.

Each.......\$0.15 Per dozen.....\$1.50

VIOLA Odorato-Sweet Violet.

Soft, purple with dark blotch.

Each.......\$0.20 Per dozen....\$2.00

YUCCA Filamentosa-Adam's Needle.

Handsome, stately, almost evergreen. Tropical appearing plant. Perfectly hardy. Flower stems from 3 to 6 feet. June and July.

Each.......\$0.40 Per dozen.....\$4.00

Large Specimens-

Each.......\$1.00 Per dozen....\$10.00 


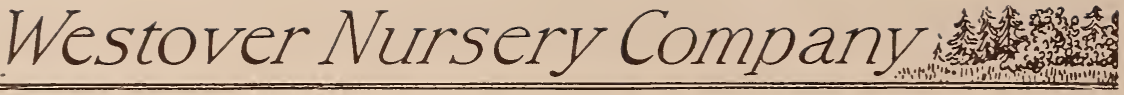

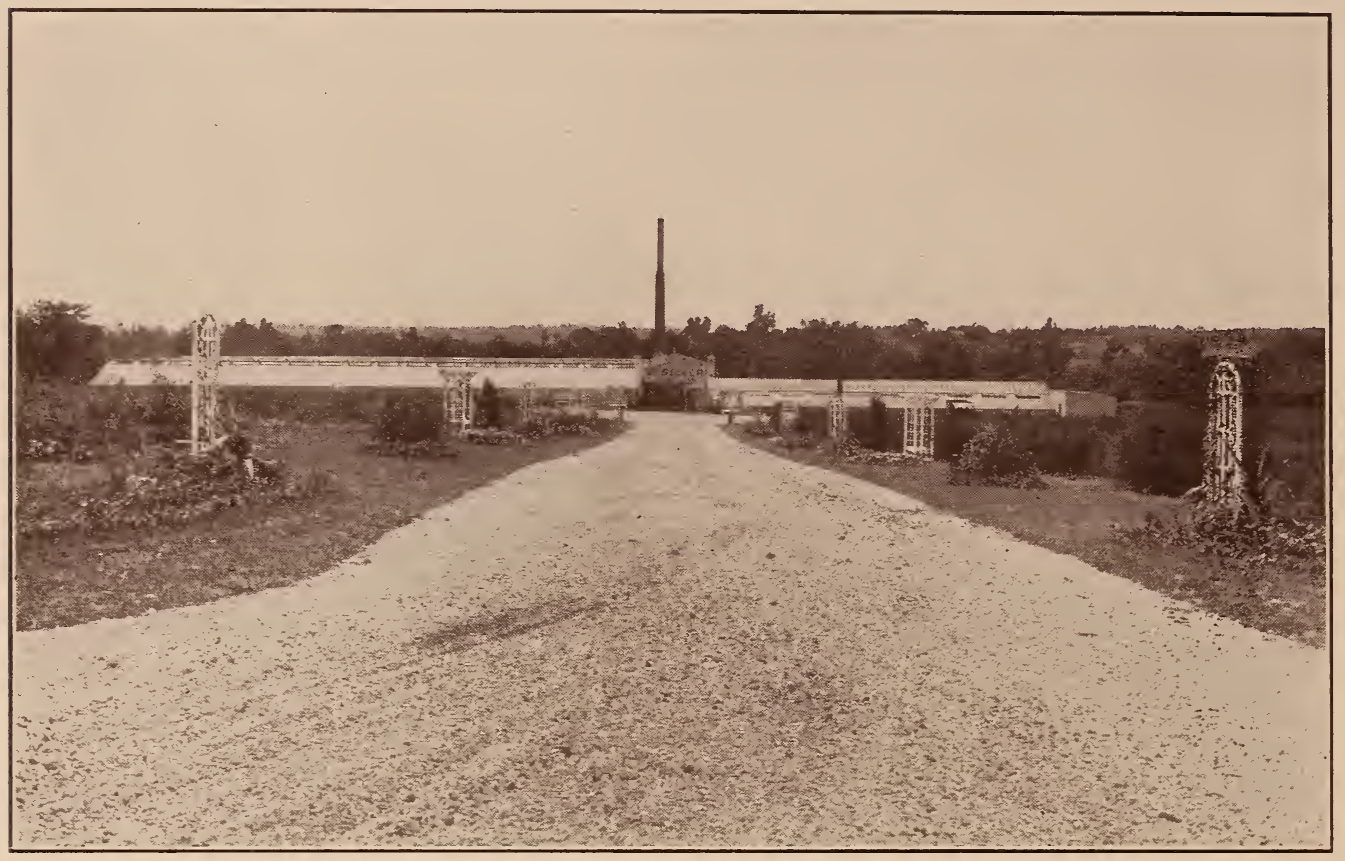

Entrance to Westover Greenhouses

\section{Greenhouse Department \\ Bedding Plants and Annuals for Spring Delivery}

\section{ABUTILON-Flowering Maple.}

Popular as pot plants and for summer bedding, vases and baskets. The flowers are deep bell shaped in various colors. Foliage green and white.

Each Dozen

3 -inch pots $\ldots \ldots \ldots \ldots \ldots \ldots \$ 0.20 \$ 2.00$

4 -inch pots $\ldots \ldots \ldots \ldots \ldots \ldots \ldots . .25 \quad 2.50$

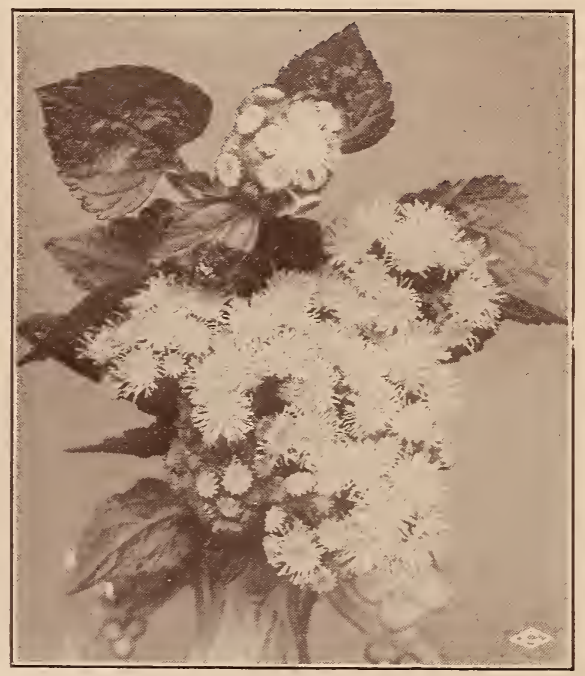

Ageratum

Page Sixty-eight

\section{ACALYPHA-}

One of the most popular types of Bedding plants, combining various attractive leaf formations with subdued but none the less effective coloring in crimson and bronze.

$\begin{array}{rrr}21 / 2 \text {-inch pots } \ldots \ldots \ldots \ldots \ldots \ldots & \begin{array}{r}\text { Each } \\ \text { Dozen }\end{array} \\ 3 \text {-inch pots } \ldots \ldots \ldots \ldots \ldots \ldots & .25 & 2.50\end{array}$

\section{ACHYRANTHES Acuminata.}

Thrives in any soil; are not easily killed by frost. They make intensely bright beds and show off splendidly in borders to taller growing plants. Foliage bronze-purple.

Each Dozen

2-inch pots ...........\$0.10 \$1.00

3 -inch pots ........... .15 1.50

A. Aurea.

Foliage greenish yellow.

\section{AGERATUM-Floss Flower.}

Fine dwarf plant for Bedding and borders. Dwarf. Bright blue.

2-inch pots ..........\$0.10 $\$ 1.00$

3 -inch pots ........... .20 2.00 


\section{ALTERNANTHERA Aurea Nana.}

Dainty foliage plant for carpet bedding. Foliage yellow and green.

Each Dozen

2-inch pots ...........\$0.10 $\$ 1.00$

Foliage bright red.

\section{A. Brilliantissima.}

ALYSSUM Little Gem-Sweet Alyssum.

Dwarf for edging. White. Each Dozen

2-inch pots ...........\$0.10 \$1.00

\section{ANTIRRHINUM-Snapdragon.}

Six distinct colors. Each Dozen

$21 / 2$-inch pots .........\$0.15 $\$ 1.50$

3 -inch pots ............ $.25 \quad 2.50$

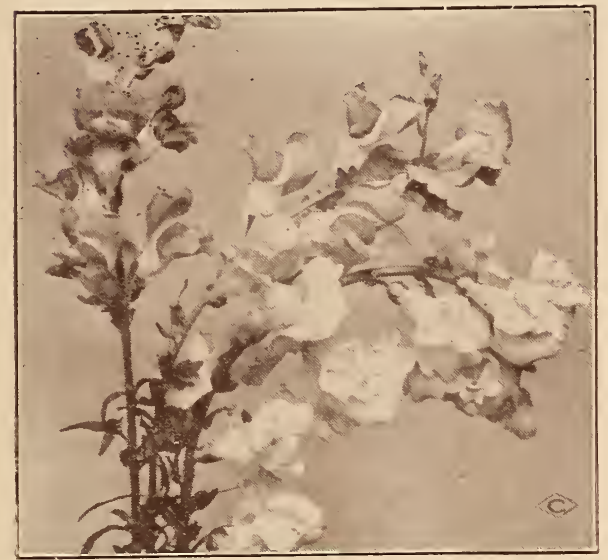

Snapdragon

\section{ASPARAGUS Plumosa Nanus.}

The lace like texture of its foliage outclasses Maiden Hair Fern for grace and daintiness. The long emerald sprays making a rich setting for cut flowers of all kinds.

$\begin{array}{rrr}3 \text {-inch pots } \ldots \ldots \ldots \ldots \ldots \ldots \ldots & \begin{array}{r}\text { Each } \\ 40.25\end{array} & \begin{array}{r}\text { Dozen } \\ \$ 2.50\end{array} \\ 4 \text {-inch pots } \ldots \ldots \ldots \ldots \ldots \ldots & .50 & 5.00\end{array}$

A. Sprengeri.

Graceful pot plant for house decoration or for hanging baskets.

\section{ASTERS Annual.}

All colors.

Each Dozen

2-inch pots

$\$ 0.10 \$ 1.00$

CALENDULA Orange and Yellow.

One of the best and showiest free-flowering Annuals. Continuing to bloom from early summer until killed by frost, excellent for cutting.

$$
2 \text {-inch pots ..........\$0.10 } \begin{array}{r}
\text { Each } \\
\$ 1.00
\end{array}
$$

\section{CANNAS -}

We call attention to our fine stock of cannas. They are offered in the best varieties, 4 inch pots, 12 to 18 inches high. Ready to plant. Each Dozen

4-inch pots............\$0.25 \$2.50

Chas. Henderson-Red.

$\$ 2.50$

Alemannia-Orange and Yellow.

Louisiana-Tall. Large Red.

Mad. Crozy-Red and Yellow.

Hungaria-Large Pink.

Mrs. Conrad-Pink.

King Humbert-Bronzed leaved. Scarlet flower.

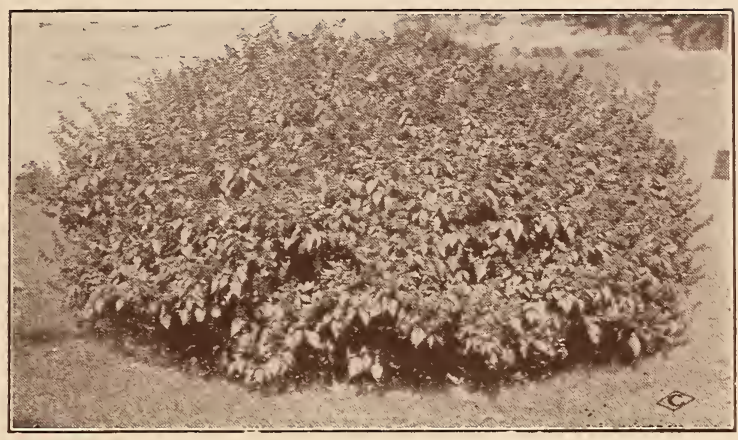

Salvia

Yellow King Humbert-Green leaved. Yellow flower

President-Red.

AQUATICS Water Plants.

Various kinds. Prices quoted upon request. CORNFLOWER Annual.

Rose, blue and white.

2 -inch pots ..........\$0.10 $\begin{array}{r}\text { Each } \\ \$ 1.00\end{array}$

\section{COSMOS}

Beautiful summer and autumn blooming plants producing thousands of artistic flowers in white, pink and crimson shades. Excellent for cutting.
2-inch pots
Each Dozen
$\$ 0.10 \$ 1.00$

CYPPERUS Alternifolius-Umbrella Plant.

A semi-aquatic plant in water or damp soil; throwing up stems 2 to 3 feet high, surmounted at the top with a whirl of slender drooping leaves.

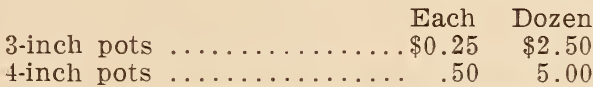

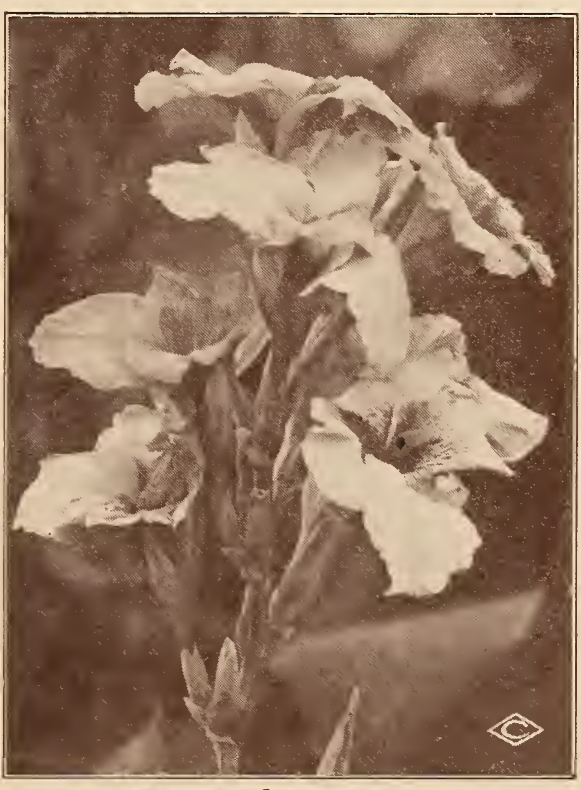

Page Sixty-nine 


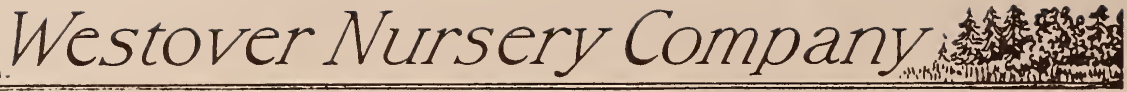

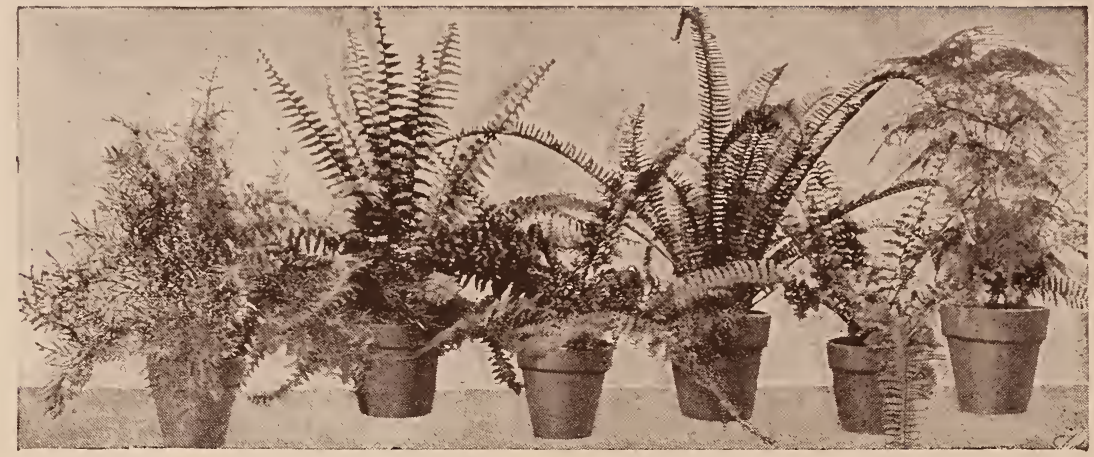

Ferns for Pots and Window Boxes

\section{CROTONS-}

Decorative foliage plants. Suitable for urns and window boxes.

Each Dozen

3-inch pots ............\$0.30 $\$ 3.00$

\section{COLEUS Flame Nettle.}

Leading varieties. Broad leaved bushy foliage plants which are unmatched for brilliancy and unique arrangement of colors. Separate or mixed colors.

Each Dozen

2-inch pots

$\$ 0.10$

$\$ 1.00$

\section{DAHLIAS-}

We have a full variety of Dahlias. It is one of the most showy of all autumn flowers. Commencing to bloom in August, they are a perfect

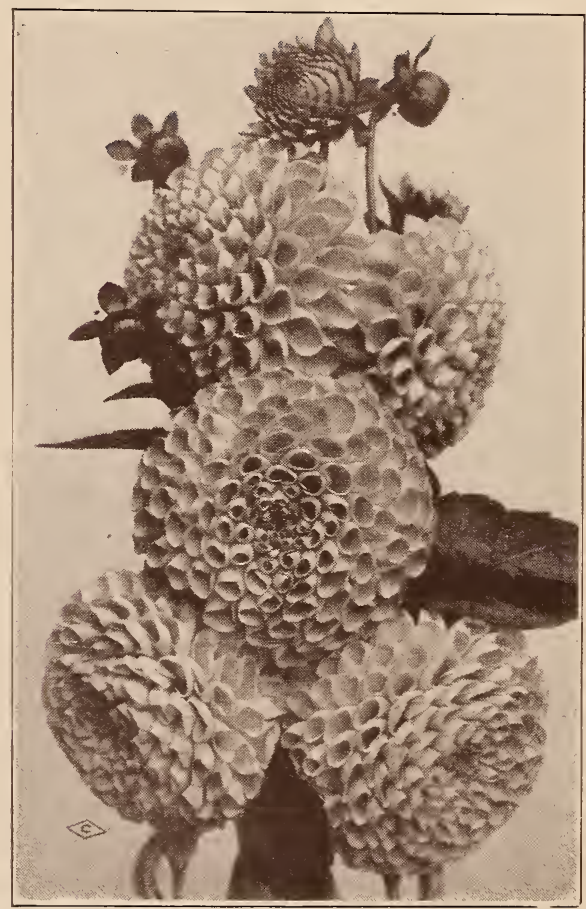

Dahlia blaze of bloom until stopped by the frost in late autumn.

Each Dozen

Price ................\$0.25 \$2.50

\section{DRACENA Indivisa.}

Numerous slender grass like green leaves. The favorite center plant for box, vase and basket planting.

Each ...................... \$0.75

\section{ENGLISH DAISY - Bellis Perenne.}

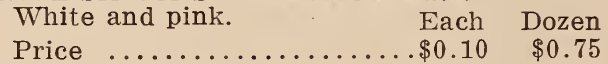

\section{EUONYMUS Japonica.}

Green leaved. Not hardy enough for permanent out-door use but valuable in pots, boxes and bedding for summer decoration. Can be taken up in the fall and carried over in the house through the winter.

\section{E. Japonica Argentea.}

Silver leaf Euonymous.

4 -inch pots $\ldots \ldots \ldots \ldots \ldots \ldots 0.50 \quad \begin{array}{r}\text { Each } \\ \$ 5.00\end{array}$

FERNS Boston, Teddy, Jr., and Whitmanii.

No foliage plant that grows presents so many varied charms or is so practical for all general house, table, floral or window decorations as the Fern.

\begin{tabular}{|c|c|}
\hline & $\begin{array}{r}\text { Each } \\
. \$ 0.25\end{array}$ \\
\hline
\end{tabular}

\section{F. Assorted Table.}

These charming little ferns are especially adapted to use in table jardinieres.

2 -inch pots $\ldots \ldots \ldots \ldots \ldots \$ 0.15 \quad \begin{array}{r}\text { Each } \\ \$ 1.50\end{array}$

FUCHIA Assorted Varieties.

Highly prized for winter blooming, also popular for summer beds in partially shaded situations and make excellent color spots in porch

$21 / 2$-inch pots

Each Dozen

.$\$ 0.25 \$ 2.50$

\section{GRASS Ornamental Fountain.}

Tender ornamental grass. Nothing equals them for border plants for Canna beds.

$21 / 2$-inch pots $\ldots \ldots \ldots \ldots \ldots+\begin{array}{r}\text { Each } \\ \text { Dozen } \\ \$ 1.50\end{array}$




\section{GERANIUMS-}

Our selections are of the best varieties. The following varieties are recommended. Price on all geraniums, unless otherwise noted.

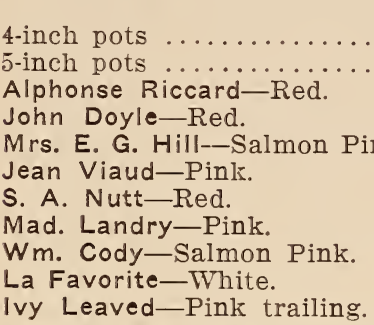
Each Dozen $\$ 0.25 \quad \$ 2.50$ $.50 \quad 5.00$ . Martha Washington or Easter Greeting. Each Dozen 4-inch pots ...........\$0.50 \$5.00

\section{HEDERA Helix-English Ivy.}

A familiar Evergreen vine, dark green leaves, favors shady locations. Used extensively to cover graves or for planting in flower boxes or jardinieres in the house.

$21 / 2$-inch pots .........\$0.15 $\begin{array}{r}\text { Each } \\ \$ 1.50\end{array}$

\section{HELIOTROPE-}

Small, fragrant blue flowers in clusters.

$$
\text { 3-inch pots ......... Each Dozen }
$$

HELICHRYSUM-Strawflower.

$$
\text { All colors. }
$$

3-inch pots

$\begin{array}{lr}\text { Each } & \text { Dozen } \\ \$ 0.15 & \$ 1.50\end{array}$

\section{HIBISCUS-}

Single and Double Red and Double Pink.

Strong growing tropical plants with glossy foliage and large, brilliant showy flowers. Make excellent center plants for flower beds or for window boxes. Single and double. Red and pink. Blooms all summer.

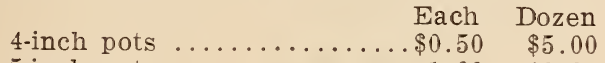

5 -inch pots ............ $1.00 \quad 10.00$

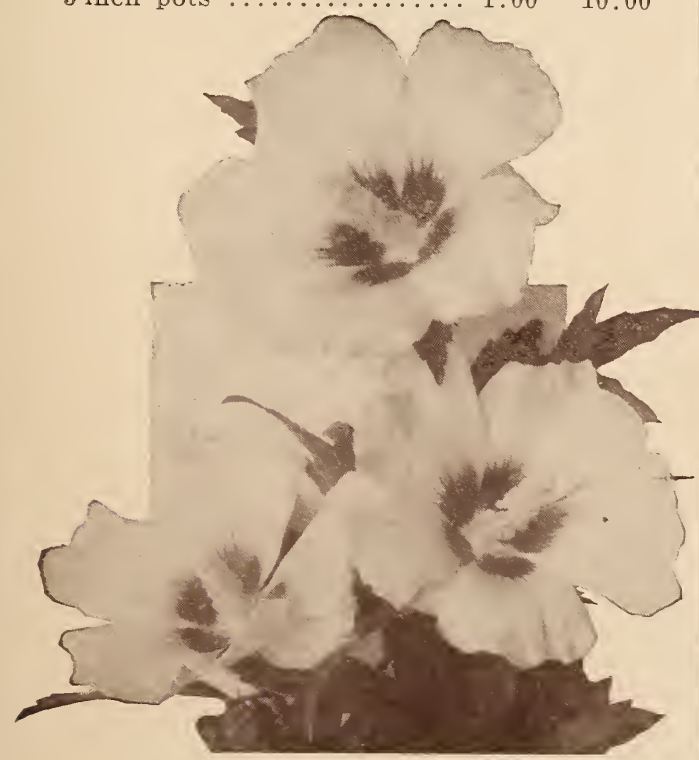

Hibiscus

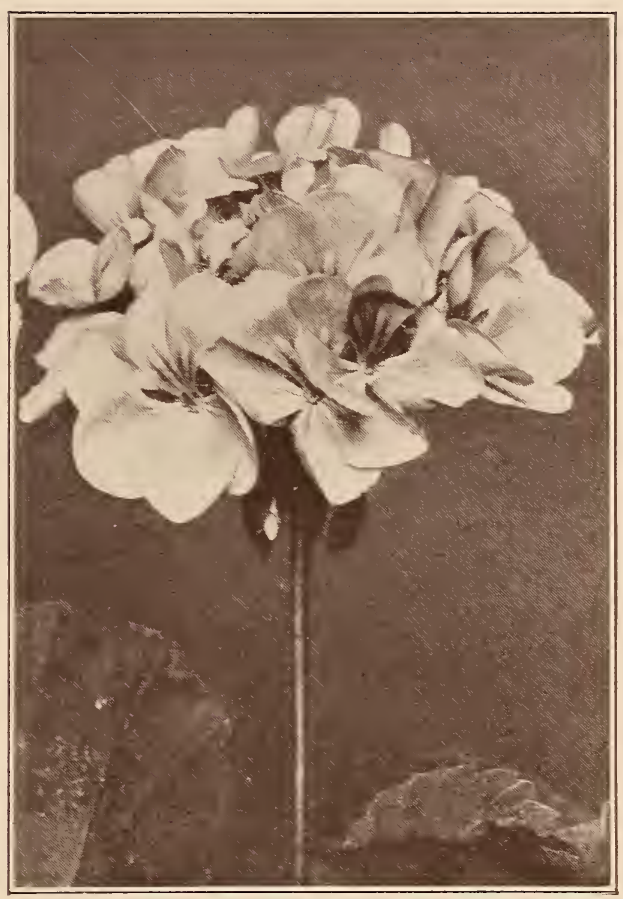

Geranium

IRESINE Lindeni.

Red foliage.

Each Dozen

2-inch pots ..........\$0.10 \$1.00

\section{LANTANA Assorted Varieties.}

White, pink, yellow and red. Useful for planting in flower beds, window boxes and

\begin{tabular}{|c|c|c|}
\hline & Each & Dozen \\
\hline inch po &.$\$ 0.20$ & $\$ 2.00$ \\
\hline nch po & & .50 \\
\hline
\end{tabular}
urns.

\section{Running}

Lavender flowers. A fine plant for hanging baskets or window boxes.

Each Dozen

3 -inch pots ..........\$0.20 \$2.00

IVY Parlor Ivy.

21/.inch Dachen

3 -inch pots .............. $15 \quad \$ 1.00$

LOBELIA.

A beautiful dwarf growing plant with deep

blue flowers. Excellent for edging beds.

Each.......\$0.10 Per dozen.....\$1.00

MARGUERITE or Daisy.

Standard sorts. Single.

Each Dozen

3 -inch pots ..........\$0.20 \$2.00

5 -inch pots $\ldots \ldots \ldots \ldots \ldots \ldots \ldots . .50 \quad 5.00$

MARIGOLD French and African.

Very popular annual for bedding and cut flowers.

$21 / 2$-inch pots $\ldots \ldots \ldots \ldots \ldots \$ 0.10 \quad \begin{aligned} & \text { Each } \\ & \$ 1.00\end{aligned}$ 


\section{Westover Nursery Company}

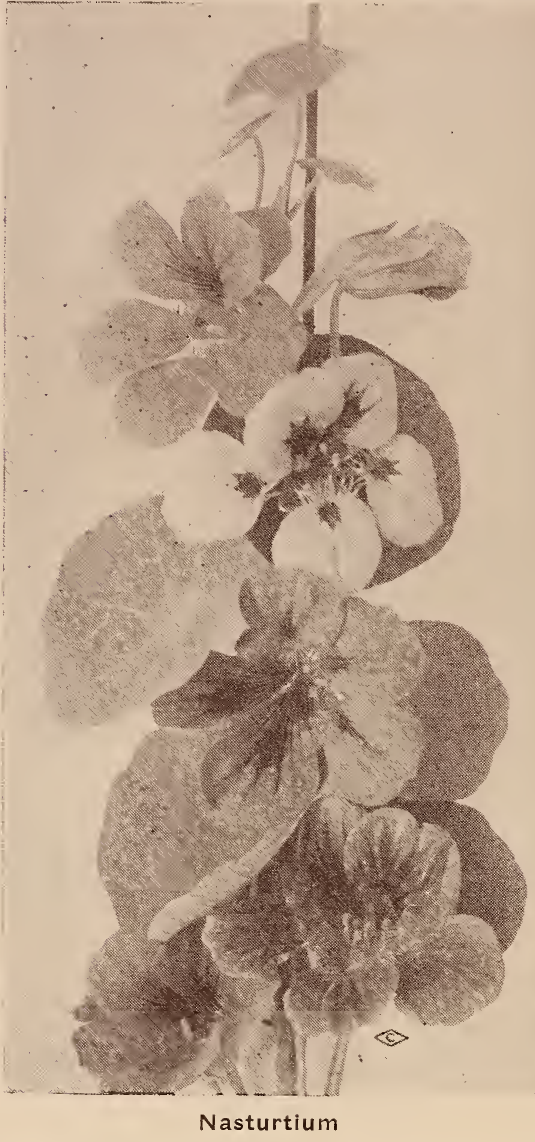

MESEMBRYANTHEMUM-California Moss.

Dwarf trailing plants with pink flowers.

3-inch pots $\ldots \ldots \ldots \ldots \ldots . \$ 0.15 \quad \begin{array}{r}\text { Each } \\ \$ 1.50\end{array}$

\section{MOONFLOWER -}

Fast growing annual climber. Pure white flowers.

4 -inch pots ..........\$0.20 $\begin{array}{rr}\text { Each } & \text { Dozen } \\ \$ 2.00\end{array}$

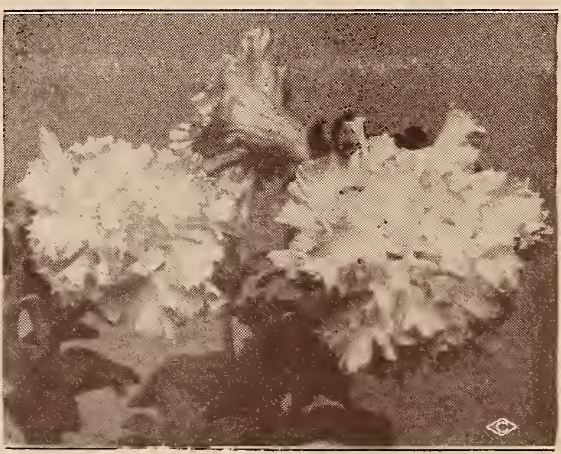

Double Petunia
M. Maxima.

Magnolia scented. These plants are propogated from cuttings and are the large white flowered Magnolia scented variety.

Each Dozen

4 -inch pots .........\$0.25 \$2.50

\section{NASTURTIUMS-}

All leading varieties. Each Dozen

2-inch pots ..........\$0.10 $\$ 1.00$

\section{PANDANUS Veitchii-Screw Pine.}

One of the best, most attractive decorative plants for the house or for center plants in urns. The leaves are light green, beautifully marked with stripes of white. Green and white foliage.

Each

4-inch pots $\ldots \ldots \ldots \ldots \ldots \ldots \ldots 1.00$

5 -inch pots .............. 2.00

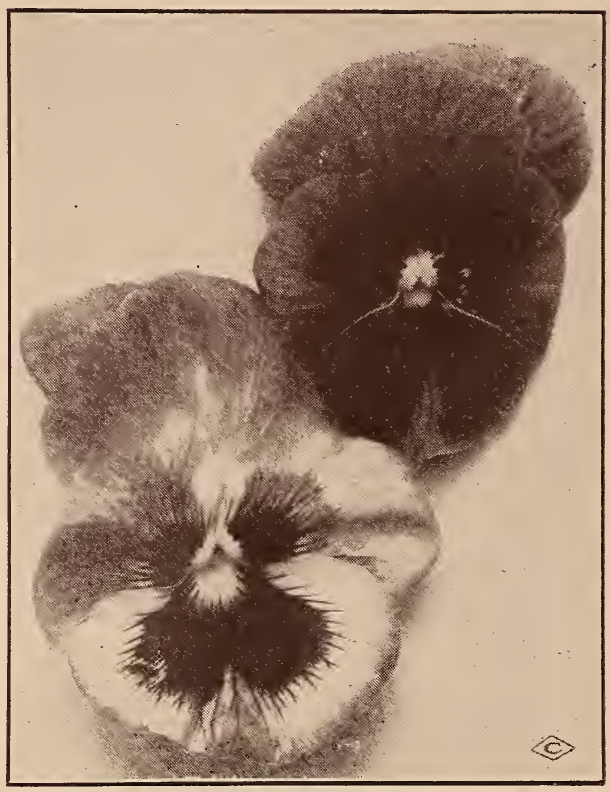

Pansy

\section{PANSIES-}

All colors, mixed.

Each Dozen

Price .............\$0.10 \$0.75

SALVIA-Scariet Sage. America, Zurich and Ostrich Plume.

The showiest and most practical red flowering plant obtainable, for summer flower beds or borders.

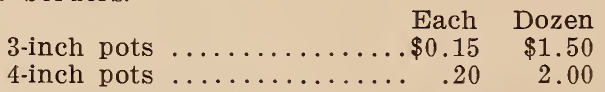

PETUNIA Double Pink, White and Red.

No plant surpasses the Petunia in bloom, can be used in beds, for window boxes or urns. Double pink, red and white.

Each Dozen

3 -inch pots ..........\$0.20 $\$ 2.00$

4 -inch pots ........... .25 2.50 


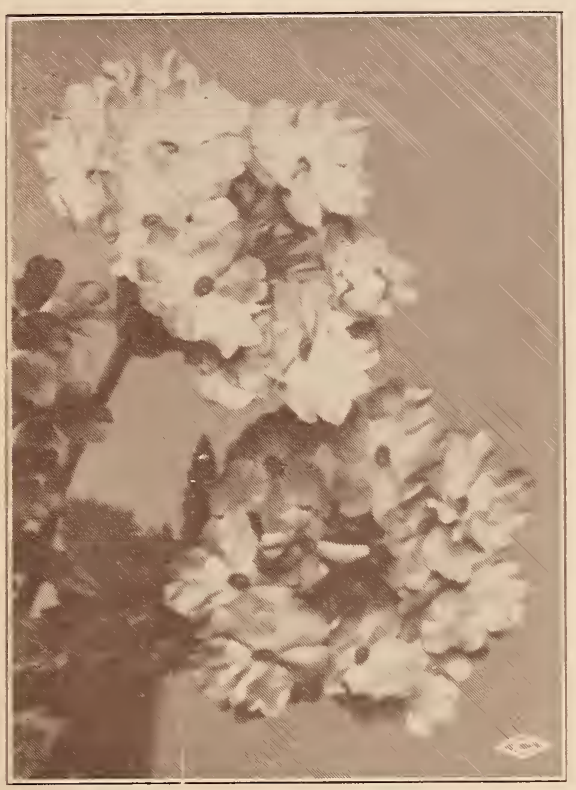

Verbena

P. California Giants.

Each Dozen

4 -inch pots ..........\$0.25 \$2.50

P. Rose Morn.

P. Balcony Rose.

P. Balcony Blue.

P. Balcony Crimson. Each Dozen

4 -inch pots ..........\$0.20 \$2.00

\section{PHILODENDRON Giganteum.}

This plant can be used as a climber or trailing vine in the sun room or conservatory.

Each Dozen

3 -inch pots ..........\$0.35 \$3.50

\section{PLUMBAGO Capensis.}

Flowers at all seasons. A fine plant for pot culture, for window boxes, vases or for the border; producing spikes of pretty light blue flowers.

Each Dozen

3 -inch pots ..........\$0.25 \$2.50

4 -inch pots $\ldots \ldots \ldots \ldots \ldots \ldots \ldots . .50 \quad 5.00$

\section{RUBBER PLANTS-}

5-inch pots. Each...........\$1.00

\section{SANSEVIERIA Zeylanica.}

An ideal decorative plant, will stand more hardship and more abuse than any other plant We know. The leaves are thick and leathery, not affected by gas, dust or heat. The leaves are beautifully striped crosswise.

4 -inch pots. Each...........\$0.75

\section{STOCKS-Gilliflower.}

One of the most popular annuals for brilliancy and diversity of color, fragrance, profusion and duration of bloom it is unsurpassed.

2 -inch pots .........\$ $\begin{aligned} & \text { Each } \\ & \$ 0.10\end{aligned} \begin{aligned} & \text { Dozen } \\ & \$ 1.00\end{aligned}$

\section{THUNBERGIA-Black-eyed Susan.}

Beautiful rapid growing annual climber, used intensively in hanging baskets, vases, low fences, etc. Produce pretty flowers in buff, white, orange, etc., with dark eyes.

2-inch pots ..........\$0.15 $\begin{array}{r}\text { Each } \\ \$ 1.50\end{array}$

\section{TRADESCANTIA-W andering Jew.}

Excellent for window boxes or hanging baskets. Three varieties.

Each Dozen

3 -inch pots ..........\$0.15 \$1.50

\section{VERBENA-}

Five leading rarieties. Assorted colors. Free bloomer.

$21 / 2$-inch pots Each Dozen

\section{VINCA Vines.}

A popular trailing plant for vases, baskets and window boxes. Each Dozen

3-inch pots ..........\$0.20 \$2.00

Large size ............... .35 4.00

\section{VINCA-Periwinkle.}

This plant blooms continuously throughout the summer. It is unexcelled for bedding or borders. Three varieties. Each Dozen

2 -inch pots ..........\$0.10 \$1.00

3 -inch pots ............... $15 \quad 1.50$

\section{ZINNIAS-}

These are old favorites in the garden and are one of the best continuous flowering annuals. All colors.

Each Dozen

2-inch pots ..........\$0.10 \$1.00

\section{SANTOLINA-}

A dwarf plant with silvery white foliage, useful as a border or for carpet bedding.

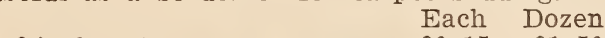

2-inch pots .........\$0.15 $\$ 1.50$

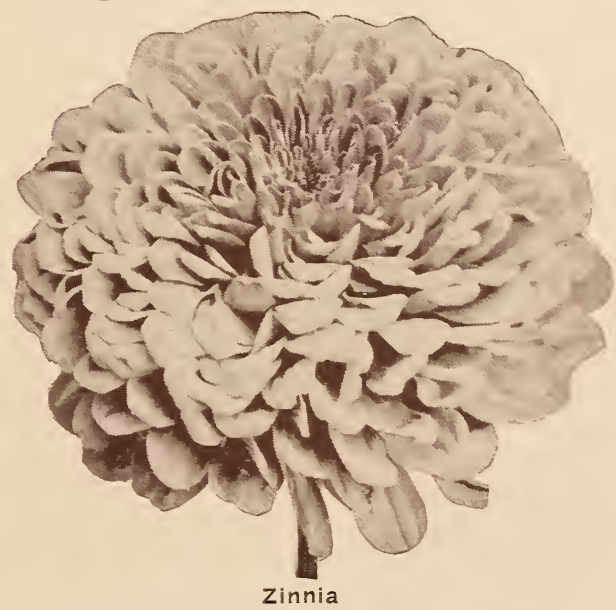

Page Seventy-three 


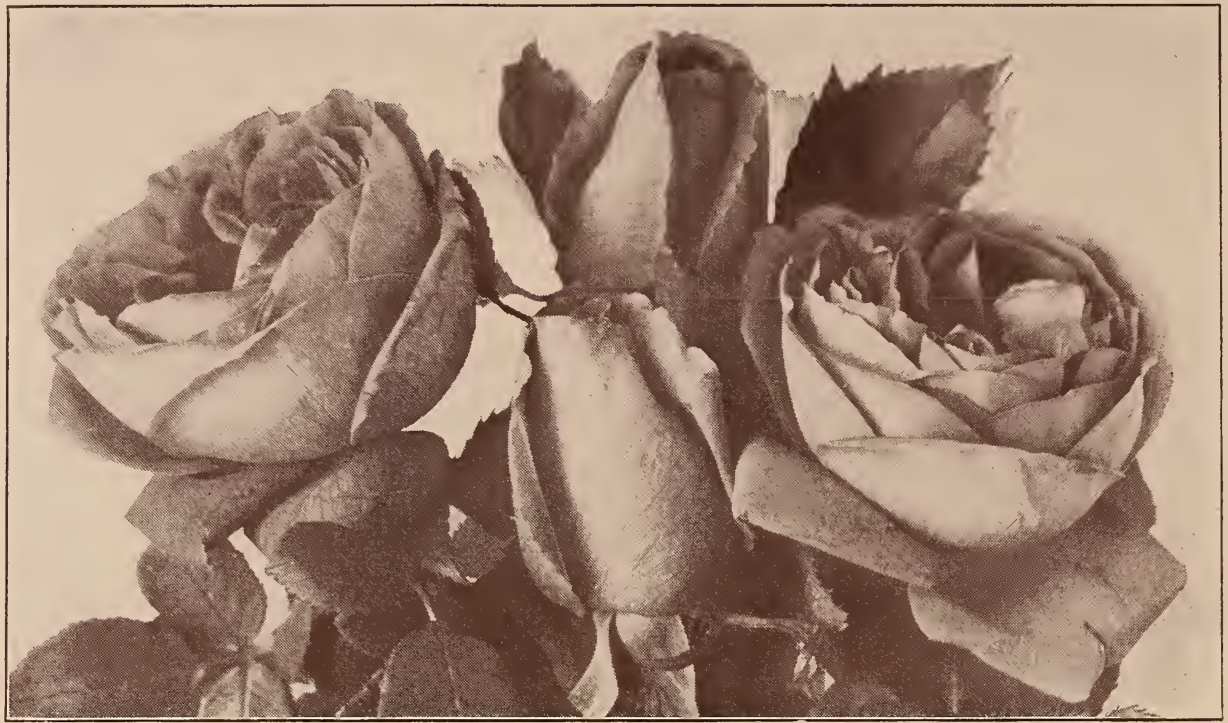

Radiance

\section{ROSES}

\section{HYBRID TEAS}

This type is termed Everblooming Roses as they bloom continuously throughout the season. They require more winter protection than do the Hybrid Perpetuals but will repay the extra care in a goodly supply of fine flowers.

Prices on all Roses:

Each Dozen

2 year, Field grown .......\$0.90 \$ 9.00

2 year, No. 15 -inch pots..... $1.00 \quad 10.00$

1 year, 4 -inch pots........ $.60 \quad 6.00$

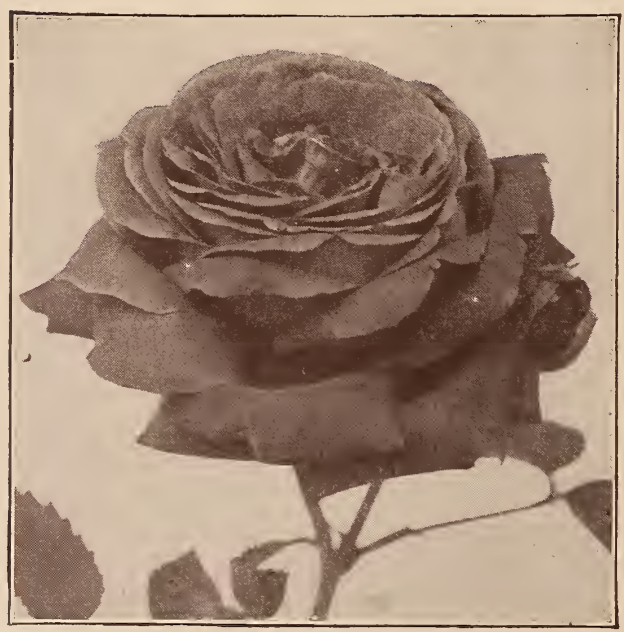

Gruss an Teplitz

\section{Wm. R. Smith.}

Thrives well in almost any situation. Flowers are large, full and double, exquisite in form, with waxy petals, softly curled. Color, cream with flesh tint tips.

\section{Clothilde Soupert.}

Thrives well in almost any situation. Flowers are white shading to deep pink.

\section{Columbia.}

Grows as well in the garden as in the hothouse. Color, a bright pink. Plant is strong and sturdy, with luxuriant foliage, and blooms continually until late fall.

\section{Crusader.}

A new introduction. Its growth is sturdy, canes erect, and has heavy foliage, producing a big crop of large velvety crimson flowers.

\section{Francis Scott Key.}

A big crimson rose, especially good. Hardy and healthy.

\section{Duchess of Wellington.}

One of the best of yellow roses. Very fragrant. Prolific. Indispensable.

\section{Elsie Beckwith.}

Rose pink.

Gen. McArthur.

A brilliant, glowing crimson-scarlet. Very sweet scented.

\section{Gruss an Teplitz.}

The choicest of bright, vivid scarlet roses, shading to crimson. Beautiful foliage. Very fragrant, hardy and strong. Blooms continuously until November. 


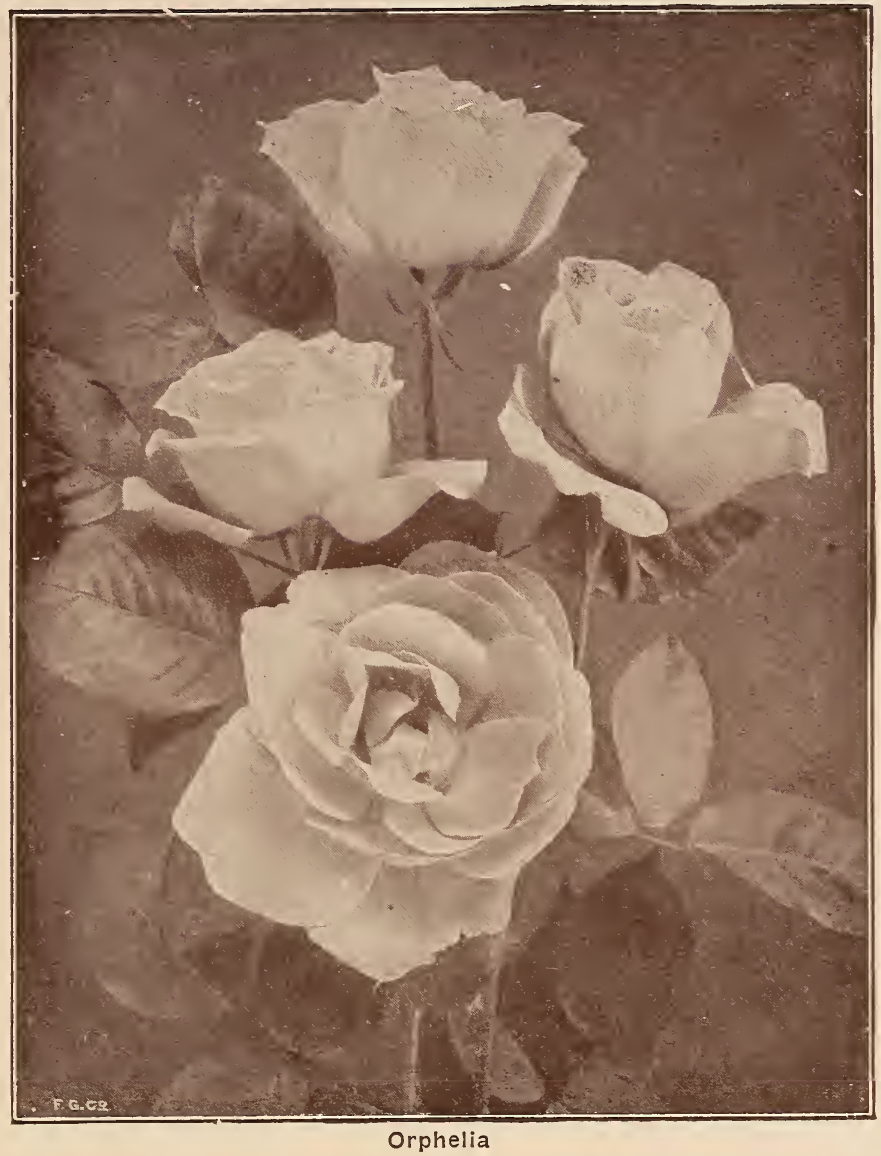

\section{Hadley.}

The large, double blossoms are a rich, deep, velvety crimson.

\section{Hermosa.}

This was one of the most popular roses for years. Daintily cupped flowers of a pretty pink. It is very hardy and ever-blooming.

\section{Jonkheer J. L. Mock.}

A novelty with immense flowers. Sometimes called a glorified La France but it is a stronger grower and blooms constantly.

\section{Kaiserine Augusta Victoria.}

One of the most popular of white roses. Large, pointed buds, and very large, full double flowers of a delicate, creamy-white and delightfully fragrant.

\section{Lady Hillingdon.}

A striking decorative Rose with deep Apricotrellow to orange flowers. It has long buds and is very free flowering.

\section{La France.}

Probably the best known and most loved of all the roses. Flowers and buds of a large size. Beautiful silvery-pink peach-blossom, changing to a deep rose. Most fragrant of any rose. Blooms while very small and continues until stopped by the frost. Must be severely pruned.

\section{Los Angeles.}

An American production that created quite a sensation. Worthy of a place in every American garden. Petals are of a bright pink. Growth is strong.

\section{Maman Cochet.}

Deep rose-pink; inner side of petals a silvery rose. Beautiful in bud or when full bloom.

Mme. Butterfly.

New sport of Ophelia, but stronger in growth and with larger blooms. Strong and vigorous, blooming constantly. Especially effective in masses.

\section{Mme. Caroline Testout.}

A rose that made Portland, Oregon streets famous. Extra large, fragrant blooms of brilliant pink. Very free blooming and hardy.

\section{Mrs. Aaron Ward.}

One of the few hardy. yellow monthly roses. Small dainty flowers of Indian yellow. Foliage, bronze-green. Plant is small, but strong and thrifty in growth. 


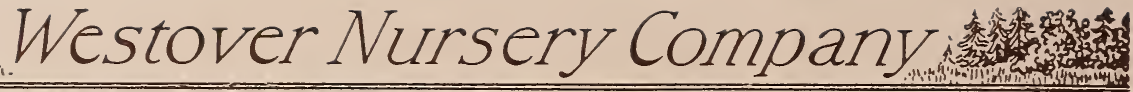

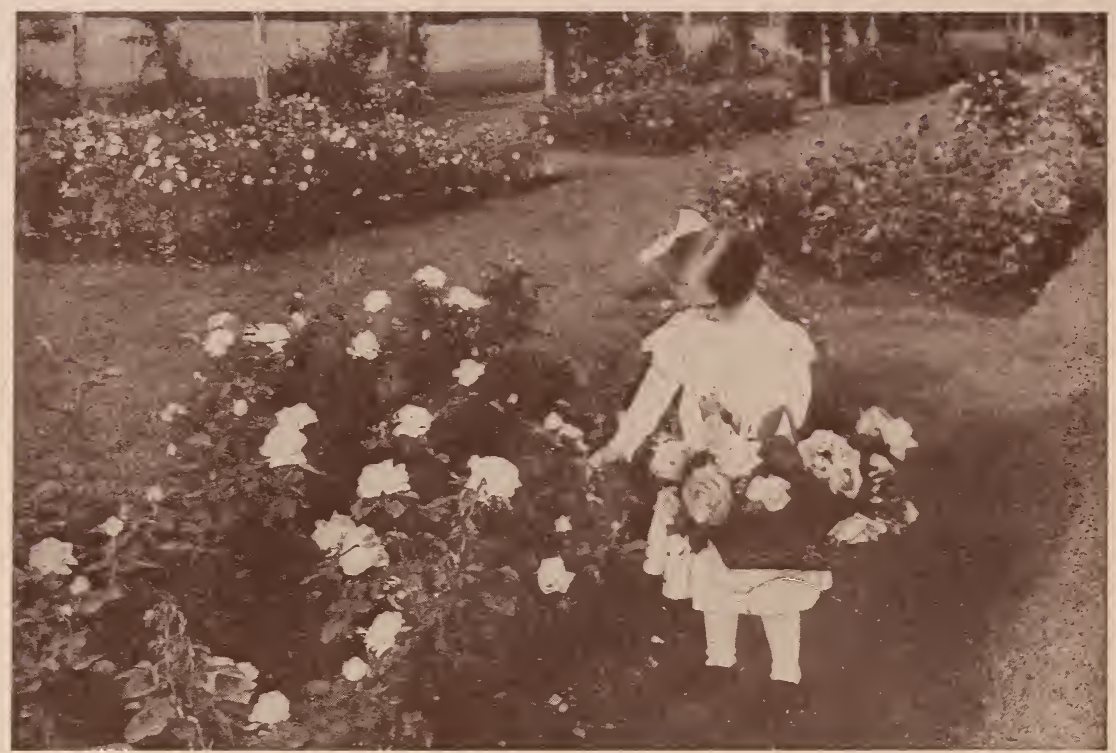

Kais. Augusta Victoria

Ophelia.

A very fragrant salmon rose. Especially beautiful in the bud and when about half open. Flowers are borne on a long stem and blossoms keep a long time after being cut. Vigorous and upright in habit. A hot-house favorite, yet very successful in the garden.

\section{Premier.}

A magnificent new variety of large size and distinct character. Very deep rose color, the broad roll of the outer petals creating most interesting lights and shadows.

Perle des Jardin. (Pearl of the Garden).

This is a clear golden-yellow of a rich and beautiful shade; flowers large, globular in form and of great depth, richly perfumed.

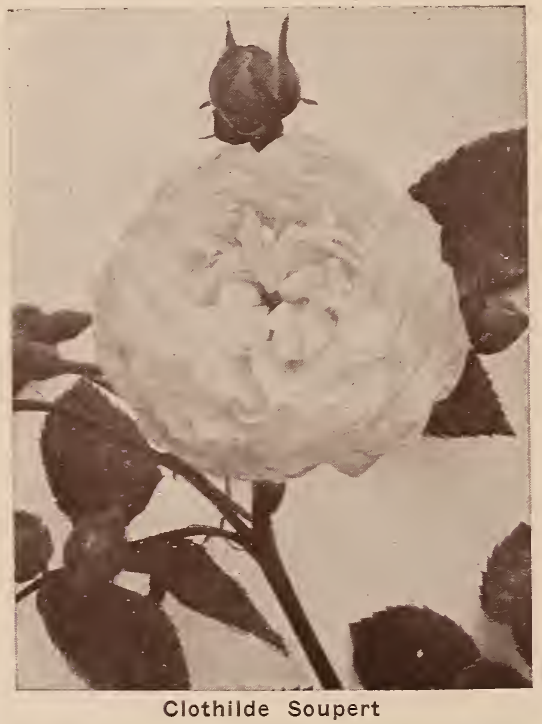

Page Seventy-six

\section{Radiance.}

This is the pink American Beauty. A beautiful blending of bright carmine with shades of opal and copper. Blooms have long stems and are very lasting as cut flowers. One of the hardiest, producing flowers from June until frost.

\section{Sunburst.}

Flowers of golden orange. Attractive, long pointed buds open full and double. A vigorous grower. Constant bloomer.

\section{White Cochet.}

One of the daintiest white roses. Very fragrant. Claimed by many as the best white rose for garden culture.

\section{Lady Alice Stanley.}

Deep coral rose on the outside of petals and pale flesh on the inside. Well shaped buds develop into splendid open blooms. Borne profusely on an unusually vigorous bush. Blooms through the whole season.

\section{Red Radiance.}

Similar in every respect to Radiance, of which it is a sport, differing only in color, which is a rich red that does not fade with age.

\section{Rhea Reid.}

A beautiful rose of scarlet-crimson that never disappoints either in bud or in bloom.

\section{Richmond.}

Free bloomer. Immense, fragrant scarletcrimson fiowers. Valuable for cutting.

\section{Duchesse of Albany.}

Pink. This is often called Red La France. It is two shades darker than its parent, the Pink La France, of which it is a duplicate in size and form. 


\section{HYBRID PERPETUALS}

These are the June Roses so admirably suited for garden culture, the formation of rose beds, hedges, etc. In June and July these lovely roses are covered with brilliant intensely perfumed flowers. The following list of Hybrid Perpetuals are priced as follows:

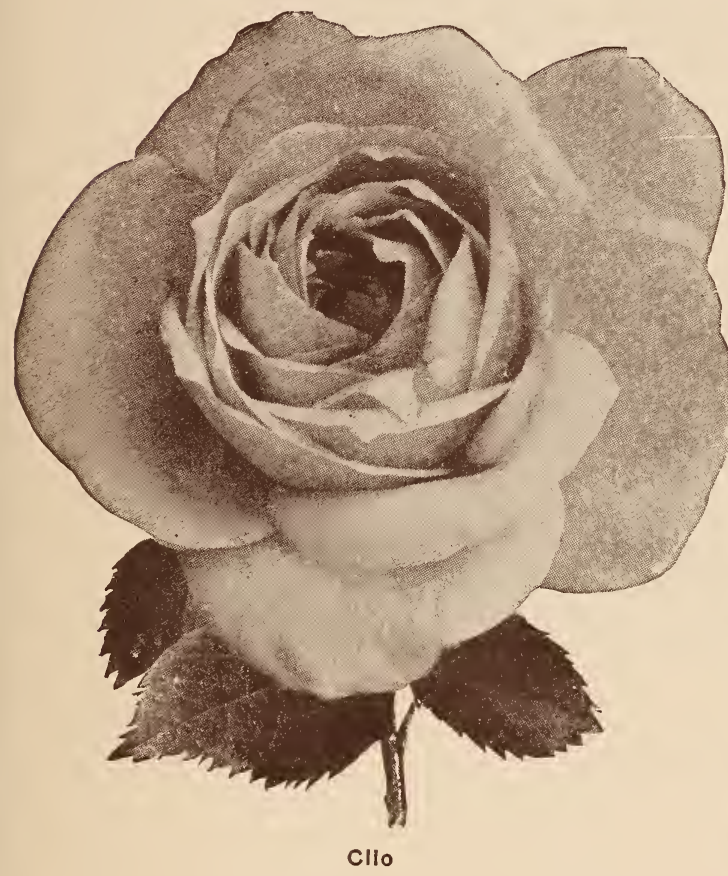

\section{Paul Neyron.}

The largest rose of all. Blossoms of clear pink, shading to rose. Plant is erect in habit and a strong, heavy grower. Blooms repeatedly through the season.

\section{Prince Camille de Rohan.}

One of the darkest red roses-almost black. Buds are well formed and the open fragrant flowers double enough to make it one of the most attractive "blacks."

\section{Ulrich Brunner.}

One with a lively, light distinctive red all its own. Flowers borne on long stems. Very fragrant, full and graceful. One of the most popular.

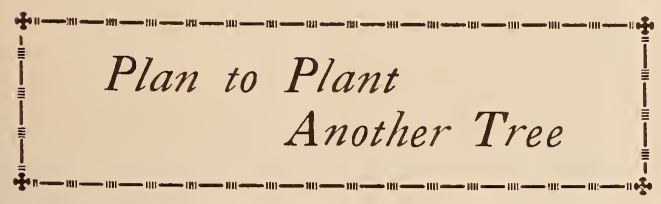

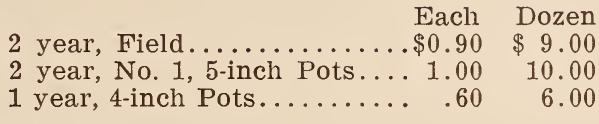

Anne de Diesbach.

Has large, well formed blossoms, deep pink to carmine. Very fragrant. One of the hardiest of the roses. A strong grower.

Clio.

A large globular rose, sweetly fragrant, with a delicate, satiny flesh-color, with pink center. At perfection, are as large as peonies. Strong grower; perfectly hardy.

Gen. Jacqueminot.

The favorite old "Jack Rose." Blooms a rich, velvety crimson. Large petals. Blooms freely. Grows anywhere.

Mrs. John Laing.

Blossoms of soft, clear pink are large and delightfully fragrant. Blooms profusely from June until mid-autumn.

M. P. Wilder.

Bright crimson-scarlet in color. Flowers, full, round and extra large. Very fragrant and desirable in any location.

\section{Magna Charta.}

A rosy pink, full round globular rose of marked fragrance. Profuse bloomer. Valuable for cutting and for this reason is used extensively by florists.

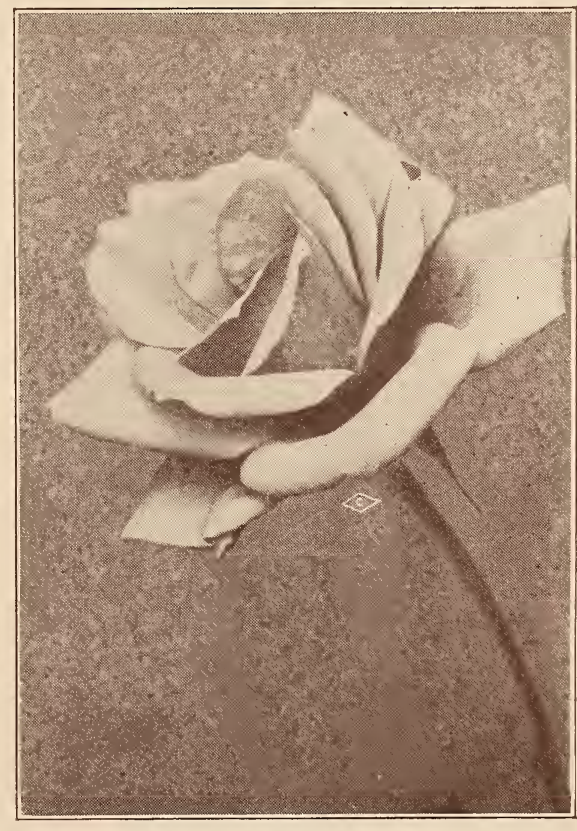

Mad. Butterfly 


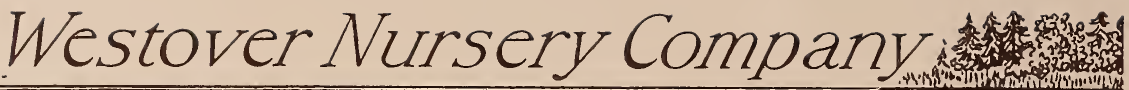

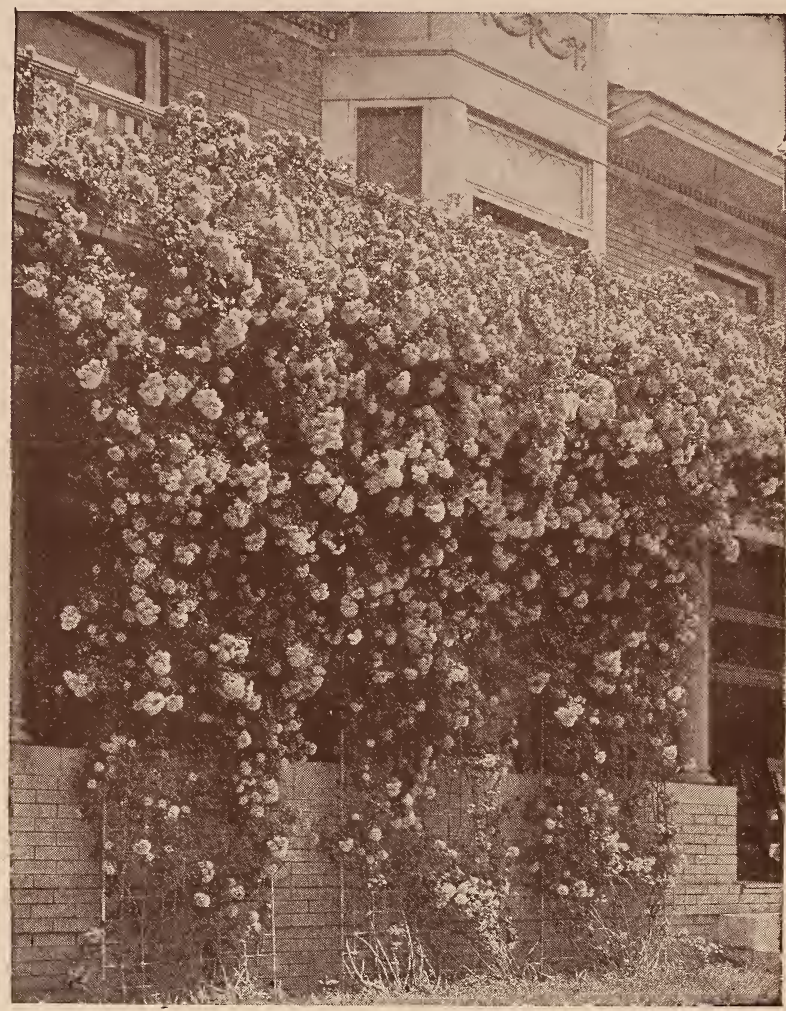

Climbing Dorothy Perkins

DWARF RAMBLERS

\section{Baby Rambler.}

Bush presents the appearance of an assembled bouquet when in bloom, except for a glimpse here and there of the deep, glossy green leaves. Has no superior as a rose-hedge. as a rose-hedge.

\section{Chatillon.}

A comparatively new variety and one of the most effective. Flowers semi-double, produced in great sprays; color a lively silvery crimson pink gradually passing to a white centre.

\section{Echo.}

Pink.

\section{Baby Tausendschon.}

Soft tender shade of pink, blooming throughout the season. Identical to the familiar and popular Tausendschon.

\section{Erna Teschendorf.}

A sport from the crimson rambler, as bright as Gruss and Tepliz, which has been described as the brightest of all roses.

\section{Ellen Poulson.}

New. A very free and vigorous type with large, full and sweet scented clusters of pink blossoms.

\section{Lafayette.}

An entirely new break in the Baby Rambler type, with brilliant cherry crimson flowers as large as Paul's Scarlet Climber; produced in immense branched trusses, free and continuous blooming.

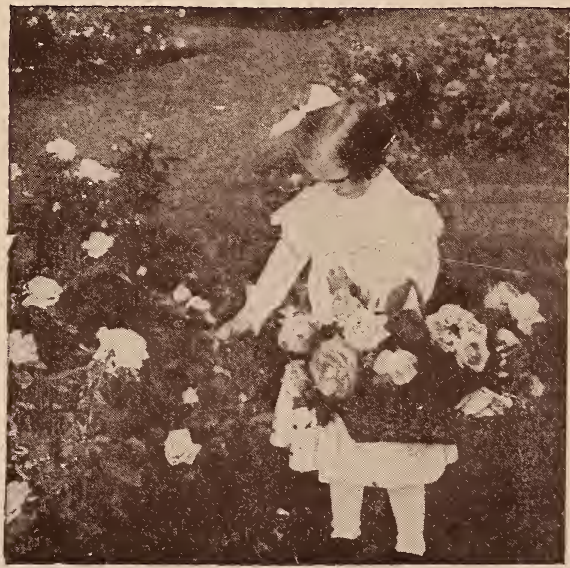




\section{Climbing Roses}

American Pillar.

A true climbing rose. Very large, glossygreen foliage, with enormous trusses of flowers. Silk rose-pink. Striking size and beauty.

\section{Baltimore Belle.}

A rigorous grower. Flowers a pale blush, turning to white, blooming in clusters. Succeeds anywhere.

\section{Bess Lovett.}

Resembles Climbing American Beauty in shape of flower, but is brighter in color, a clear bright red. of good size and of double fullcupped form. A strong, vigorous grower and very fragrant.

\section{Crimson Rambler.}

This was the first of the ramblers introduced from Japan in 1894. Too well known to require a description.

\section{Dorothy Perkins.}

A clear, cherry-pink of sweet fragrance. Always gives satisfaction because it is a rapid grower and always healthy. One of the very best climbers.

\section{Emily Gray.}

In this we have a real yellow Climbing Rose as hardy as Dr. Van Fleet. The buds are long and pointed, of splendid shape. The foliage is dark glossy holly like.

\section{Eugene Jacquet.}

Crimson. This is a very new variety. The flowers which are fragrant are cherry-red, borne profusely in large clusters.

\section{Excelsa.}

This is the Red Dorothy Perkins. Color an intense clear red. Blooms small, perfect and double. Borne in large clusters. Of great rigor and hardiness.

\section{Gruss an Teplitz, Climbing.}

Vivid fiery crimson. An exact duplicate of the bush rose of this name except that it is a vigorous climber producing a sheet of dazzling bloom. Superb for pillars.

\section{Mary Lovett.}

Large well-formed flowers of pure waxy white. streetly scented.

\section{Mary Wallace.}

$\pi$ ell formed, semi-double flowers of a bright rose-pink, with salmon base to the petals. Flowers large and very free flowering.

\section{Lady Gay.}

A beautiful cherry pink, fading to soft white; the flowers, in large, loose trusses, together with the buds and foliage form a mass of beauty from base of vine to tips of branches. Perfectly- hardy.

\section{Tausendschon.}

Entirely different. In a single cluster of blooms, there will be all shades from light pink to a rosy carmine, some almost white, with a suggestion of yellow.

\section{American Beauty (Climber).}

One of the best climbers. Rose pink in color, of splendid form and good substance.

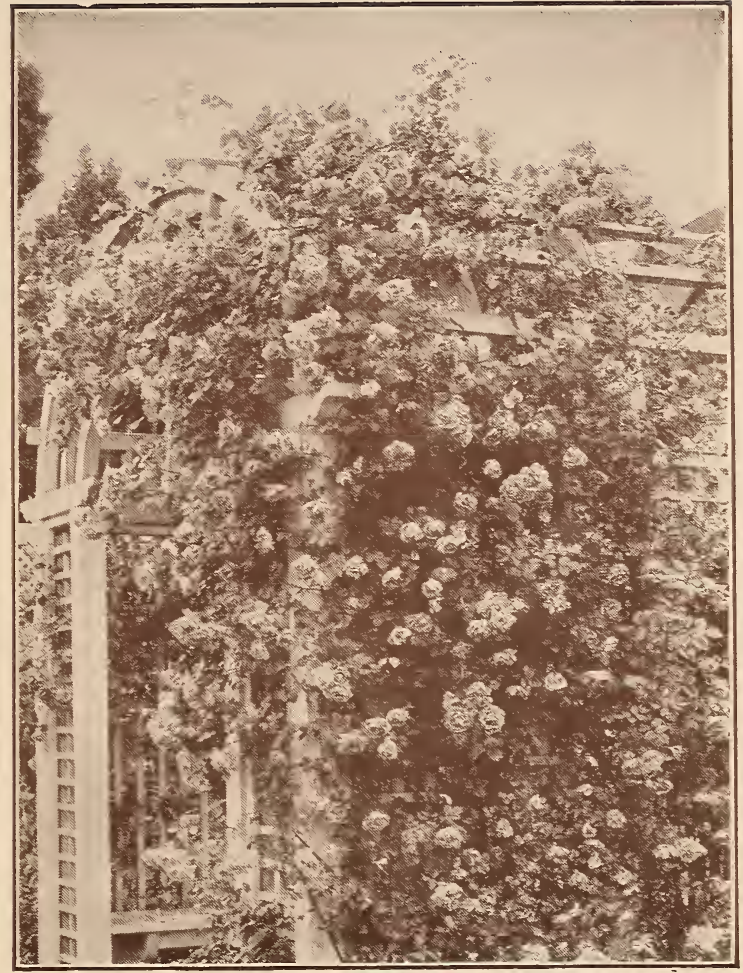

\section{Rosarie.}

Climbing Rosarie

This is a sport from Tausendschon. It is true cerise-pink; a good grower and bloomer. Flower of Fairfield.

Known to many as the everblooming Crimson Rambler. Very desirable.

\section{Gardenia.}

This is often called "The Hardy Marechal Neil." It is bright yellow, opening cream; early flowering. Fragrant and free.

Dr. W. Van Fleet.

This rose appeals to all. Has dainty flesh pink color and exquisitely shaped buds.

\section{Silver Moon.}

Different from all other roses. Has beautiful semi-double flowers four and one-half inches in diameter. Pure white in color.

\section{Paul's Scarlet Climber.}

A new rose of brilliant, vivid scarlet, maintained without burning or bleaching until the petals fall. Semi-double flowers of medium size completely cover the vine.

Wichuriana (Memorial Rose).

A trailing rose that covers the ground with glossy, small green leaves. Single, pure white flowers with yellow anthers in the center. Hardy. Ideal for covering embankments.

\section{Moss Roses}

The beauty of the Moss Rose consists in the delicate mossy covering which surrounds the buds and gives the opening flowers a unique appearance.

Salet.

Rose pinl.
Princess Adelaide. Rose pink.
Mousseline. White. 


\section{GENERAL INDEX}

Classification of Ornamental Shrubs ............27-45 Classification of Ornamental

Trees ................ 8-19 Evergreens
Evergreen Shrubs ..........27 Fruit Department .......46-52 Greenhouse Department...68-79 Bedding Plants and Annuals
Roses $\ldots \ldots \ldots \ldots \ldots \ldots \ldots$ 74-79 Shrubs, Deciduous …...27-45 Transplanting Directions Trees, Deciduous ......... $8-19$ Perennials ................ 55-67 Vines and Climbers..........53-54

\section{VARIETY INDEX}

Abies

Abutilon

20-21

Acalypha ...................... 68

.

Achillea ................. 55

Achyranthes ...........6.68

Adam's Needle .............67

Aesculus $\ldots \ldots \ldots \ldots \ldots \ldots \ldots . .69$

Ageratum ............... 68

Alder

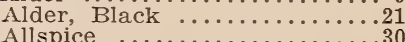

Allspice Almond, Flowering ...............29

Alnus ...................... 9

Alternanthera ............ $27-289$

Alyssum, Annual .......... 27-28-55

Alyssum, Annual $\ldots \ldots \ldots \ldots \ldots 69$

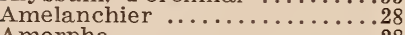

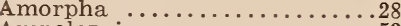

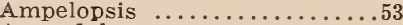

Amygdalus ................23

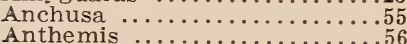

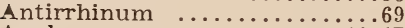

Apples ...............46-47

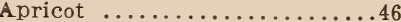

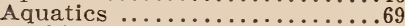

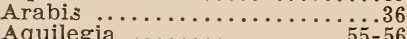

Aquilegia $\ldots \ldots \ldots \ldots \ldots \ldots \ldots \ldots 55-56$

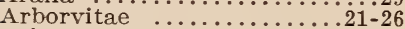

Aristolochia $\ldots \ldots \ldots \ldots \ldots \ldots \ldots 53$

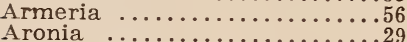

Arrow-Wood ...............44

Asparagus .............. 52-69

Asplenium .................. An

Asters, Annual ........... 69

Ash ......................

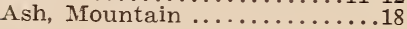

Baby's Breath .............60

Balloon Flower ................66

Baptisia ..................... 56

Barberry .................... 29

Beauty Fruit .....................

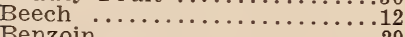

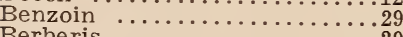

Bergamont $\ldots \ldots \ldots \ldots \ldots \ldots \ldots \ldots \ldots \ldots \ldots$

Betula .................. 9.10

Bignonia $\ldots \ldots \ldots \ldots \ldots \ldots \ldots \ldots \ldots . \ldots \ldots \ldots$

Biota $\ldots \ldots \ldots \ldots \ldots \ldots \ldots \ldots 21$

Birch ...............

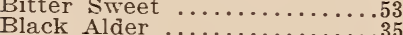

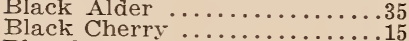

Blackberries ................

Blackhaw ................ 45

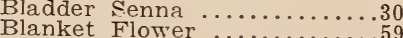

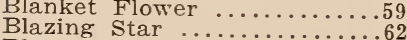

Bleeding Heart . . . . . . . . . .

Blue Bells ...................... 63

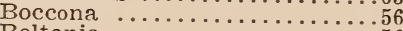

Boltonia ..........................

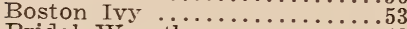

Bridal Wreath $\ldots \ldots \ldots \ldots \ldots \ldots 42$

Buckbrush ................. 42

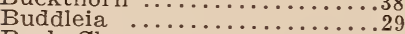

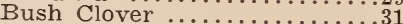

Butterfly Bush .............29

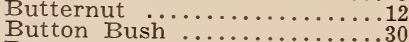

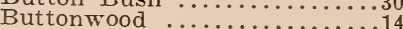

Cabbage Plants .............52

Calendula $\ldots \ldots \ldots \ldots \ldots \ldots \ldots . . \ldots 69$

California Moss ................ . .

Calycanthus $\ldots \ldots \ldots \ldots \ldots \ldots \ldots . . \ldots \ldots$

Campanula ....................
Candvtuft, Hardy ..........60

Cannas ................... . . . . . . . . 59

Canterbury Bells ...........57

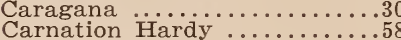

Carolina Allspice ................

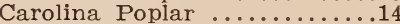

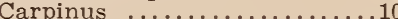

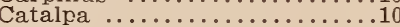

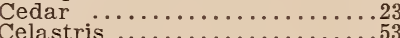

Celastris ................

Celtis ...................... . . . . . . . .

Cephalanthus $\ldots \ldots \ldots . . . . . .30$

Cercis ................................

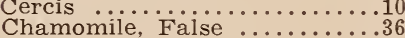

Chaste Tree ................. 45

Cherry $\ldots \ldots \ldots \ldots \ldots \ldots \ldots \ldots .49$

Chestnut, Horse $\ldots \ldots \ldots \ldots \ldots \ldots . . \ldots$

Choke Cherry ..........................

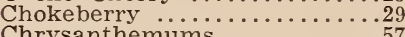

Chrysanthemums ..........5

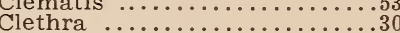

Clove Pinks ......................

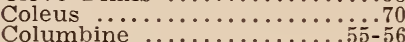

Columbine ............. $55-56$

Cone Flower .............66

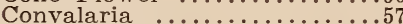

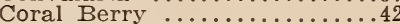

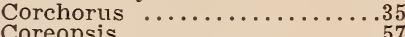

Coreopsis ................. 57

Corn Flower, Hardy.......... 57

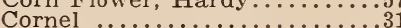

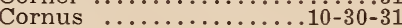

Corylus .....................

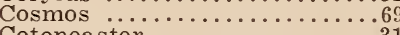

Cotoneaster ..................

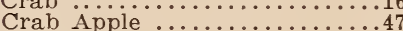

Crataegus $\ldots \ldots \ldots \ldots \ldots \ldots \ldots \ldots . \ldots \ldots \ldots$

Creeping Jenny ...........6. 63

Crow-Foot $\ldots \ldots \ldots 66$

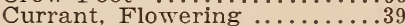

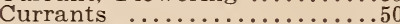

Cupressus $\ldots \ldots \ldots \ldots \ldots \ldots \ldots 21$

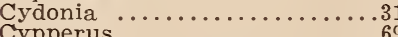

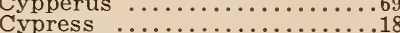

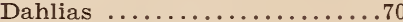

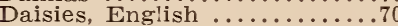

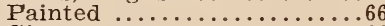

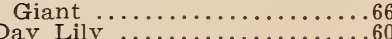

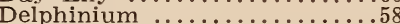

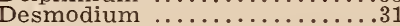

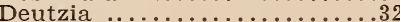

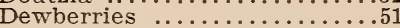

Dianthus $\ldots \ldots \ldots \ldots \ldots \ldots \ldots . \ldots \ldots 8$

Dicentra ............. 58

Diervilla $\ldots \ldots \ldots \ldots \ldots \ldots \ldots 45-46$

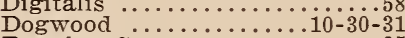

Douglas spruce ...........25

Dracena $\ldots \ldots \ldots \ldots \ldots \ldots \ldots \ldots . \ldots \ldots 70$

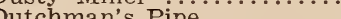

Egg Plants .............. 52

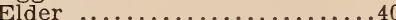

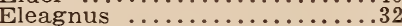

Elm

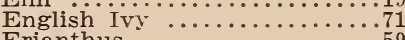

Erianthus $\ldots \ldots \ldots \ldots \ldots \ldots \ldots$

Eryngium $\ldots \ldots \ldots \ldots \ldots \ldots \ldots 58$

Eula lia …......... $27-32-33-54-59$

Eupatorium ….......... 59

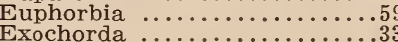

Fagus $\ldots \ldots \ldots \ldots \ldots \ldots \ldots \ldots \ldots \ldots$

False Chamomile ...........56

False Dragon Head ........66

False Indigo ................56
Ferns, Greenhouse ........ . 70

Ferns, Hardy .......... . 59

Cinnamon .................. 59

Ostrich .................... 59

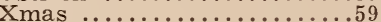

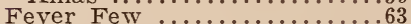

Ficus

Filbert $\ldots \ldots \ldots \ldots \ldots \ldots \ldots \ldots \ldots \ldots \ldots \ldots \ldots \ldots \ldots$

Fire Bush ..........................

Flame Nettle ................70

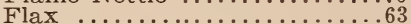

Fleur de Lis............60 60 $61-62$

Floss Flower ..............68

Flowering Crab Apple.........16

Flowering Plum ............16

Forget-me-not $\ldots \ldots \ldots \ldots \ldots \ldots .6334$

Forsythia Fountain Grass ............... $59-70$

Foxglove $\ldots \ldots \ldots \ldots \ldots \ldots \ldots .58$

Fraxinus $\ldots \ldots \ldots \ldots \ldots \ldots \ldots \ldots . . .11-12$

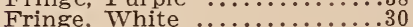

Fuchia

Fuchia $\ldots \ldots \ldots \ldots \ldots \ldots \ldots \ldots \ldots \ldots$
Funkia $\ldots \ldots \ldots \ldots \ldots \ldots \ldots$

Gaillardia ................. 59

Geraniums ................

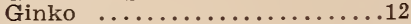

Gleditschia $\ldots \ldots \ldots \ldots \ldots \ldots \ldots \ldots \ldots \ldots \ldots$

Golden Bell ................ 33-34

Golden Chain ...............

Golden Glow .............66

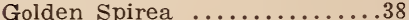

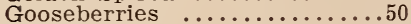

Golden Tuft ..................

Grapes Gra............... 51

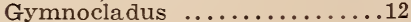

Gypsophilia .................60

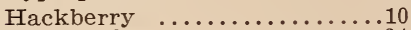

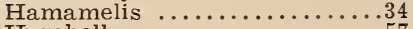

Harebell ..................

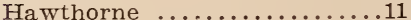

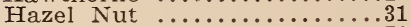

Hedera .................. 71

Helenium $\ldots \ldots \ldots \ldots \ldots .660$

Helichrysum ..............71

Heliopsis ..............60

Heliotrope, Greenhouse ......71

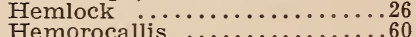

Hemorocallis $\ldots \ldots \ldots \ldots \ldots \ldots 60$

Hibiscus, Hardy ......27-28-60

Hibiscus, Greenhouse .......71

High Bush Cranberry..........

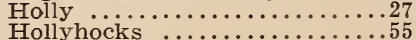

Honey Locust ..............12

Honeysuckle, Bush ...............

Honeysuckle vine ............ . . .

Hornbeam

Horse Chestnut .............

House Leak ................67

Hydrangea ..............34-35

Iberis $\ldots \ldots \ldots \ldots \ldots \ldots \ldots$

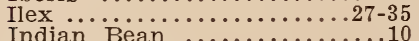

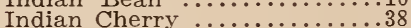

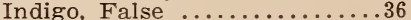

Indigo Shrub ....................

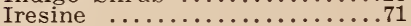

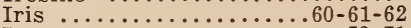

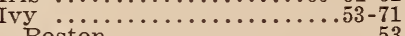

$\ldots \ldots \ldots \ldots \ldots \ldots$

Engelmanni ............. 53

English .................. 71

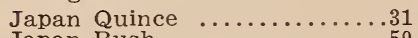

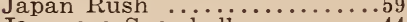

Japanese Snowball .........44

Japanese Spurge ............63

Jerusalem Cross ...............63

Judas Tree .............. 10

June Berry .............................

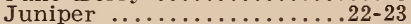

Juniperus $\ldots \ldots \ldots \ldots \ldots \ldots \ldots \ldots 22-23$ 


\section{VARIETY INDEX - Continued}

Kansas Gay Feather.......6. 62 Kentucky Coffee Tree........ 12 Kerria, White $\ldots \ldots \ldots \ldots \ldots \ldots \ldots \ldots$ Koelreuteria $\ldots \ldots \ldots \ldots \ldots \ldots \ldots \ldots \ldots \ldots$ Kudzu vine $\ldots \ldots \ldots \ldots \ldots \ldots \ldots \ldots$

Laburnum ...............13

Lantana ..................

Larch $\ldots \ldots \ldots \ldots \ldots \ldots \ldots \ldots$

Larix ......................

Larkspur $\ldots \ldots \ldots \ldots \ldots \ldots \ldots 68$

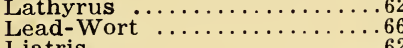

Liatris $\ldots \ldots \ldots \ldots \ldots \ldots \ldots \ldots 6, \ldots \ldots \ldots$

Ligustrum ...........

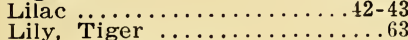

Lily of the Valley..............

Lilies, Hardy ................ 63

Lilium $\ldots \ldots \ldots \ldots \ldots \ldots \ldots \ldots 6$

Linden ...................

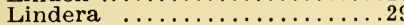

Linum .......................

Liquidamber $\ldots \ldots \ldots \ldots \ldots \ldots 13$

Lirodendron $\ldots \ldots \ldots \ldots \ldots \ldots \ldots$

Lobelia $\ldots \ldots \ldots \ldots \ldots \ldots \ldots \ldots \ldots \ldots \ldots \ldots \ldots+12$

Lombardy Poplar ............

Lonicera ..............36-37-54

Loose-Strife ...................63

Lychnis $\ldots \ldots \ldots \ldots \ldots \ldots \ldots \ldots, \ldots \ldots \ldots$

Lycium $\ldots \ldots \ldots \ldots \ldots \ldots \ldots \ldots \ldots \ldots$

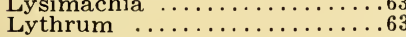

Madonna Lily $\ldots \ldots \ldots \ldots \ldots \ldots 6$

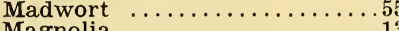

Magnolia $\ldots \ldots \ldots \ldots \ldots \ldots \ldots \ldots$

Mahonia $\ldots \ldots \ldots \ldots \ldots \ldots \ldots \ldots \ldots \ldots \ldots$

Maiden Hair Tree.............12

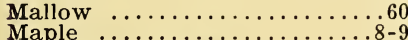

Maple $\ldots \ldots \ldots \ldots \ldots \ldots \ldots .6 \%$

Marguerite ..............71

Marigold ..................71

Matricaria ................63

Meadow Sage $\ldots \ldots \ldots \ldots \ldots \ldots 66$

Meadow Sweet ................

Matrimony Vine $\ldots \ldots \ldots \ldots \ldots \ldots \ldots 4$

Mertensia ................6. 63

Mesembryanthemum ........72

Michaelmas Daisies .........56

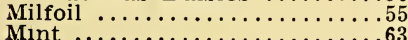

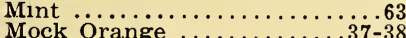

Monarda ..................6. 63

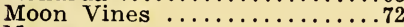

Morus

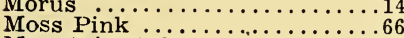

Mountain Ash ................18

Mulberries $\ldots \ldots \ldots \ldots \ldots \ldots \ldots 14$

Myosotis $\ldots \ldots \ldots \ldots \ldots \ldots \ldots \ldots, 63$

Myrtle Trailing $\ldots . . \ldots \ldots \ldots \ldots 67$

Nasturtium $\quad \ldots \ldots \ldots \ldots \ldots \ldots 72$

Ninebark $\ldots \ldots \ldots \ldots \ldots \ldots \ldots \ldots \ldots \ldots \ldots$
Nut Trees

Oak ................16-17

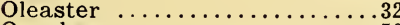

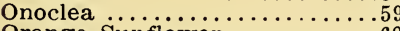

Orange Sunflower $\ldots \ldots \ldots \ldots 60$

Ornamental Fountain Grass..59

Osmonda ..................59

Pachysandra

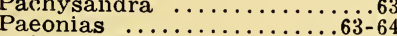

Painted Daisy ..................66

Pampas Grass ............... 59

Pampas Grass $\ldots \ldots \ldots \ldots \ldots \ldots .6 \%$

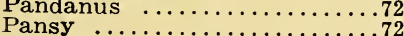

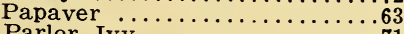

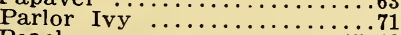

Peach ..................4 $47-48$

Peach, Flowering ...............

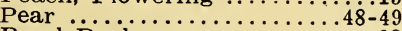

Pearl Bush $. . \ldots \ldots \ldots \ldots \ldots \ldots \ldots \ldots \ldots \ldots+33$

Pennesitum …....... 59-70

Pentstemon $\ldots \ldots \ldots \ldots \ldots \ldots \ldots 65$

Pepper Mint $\ldots \ldots \ldots \ldots \ldots \ldots \ldots \ldots \ldots+62$

Pepper Plants $\ldots \ldots \ldots \ldots \ldots \ldots \ldots 2$

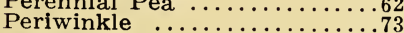

Periwinkle $\ldots \ldots \ldots \ldots \ldots \ldots \ldots \ldots \ldots \ldots$
Petunia $\ldots \ldots \ldots \ldots$

Phalaris

$2-73$
-59
$7-38$
Philodendron

Phlox .........

Physostegia

Picea

Pin Oak ...

Pine

Pinks

Plane

Plantain Lily

Platanus

Platycodon

Plum, Flowering

Plum, Purple Leaf

Plumbago

Plumbago, Greenhouse

Plume Popp

Polygonum

Poplar

Poppy

Populus

Privet

Pseudotsuga

Pueraria

Purple Fringe

Purple Leaf Plum.

Pussy Willow

Pyrus

Quercus

Quince

Quince. Japan

Ranunculus

Raspberries

Raspberry, Flowering

Red Hot Poker

Rhamnus

Rhodotypos

Rhubarb

Ribbon Grass

Ribes .

Rosa

Roses

Climbing

Dwarf Ramblers

Dwarf Wild ........

Hybrid Teas.

Hugonis

Japanese

Meadow

Memorial

Moss

Persian Yellow

Prairie

Red Leaved

Rugosa

Swamp

Sweet Briar

Rose Champion

Rose of Sharon

Rubber Tree

Rubus

Rudbeckia

Russian Olive

Salisburia

Salix

Salvia, Greenhouse

Sambucus

Sanseviera

Scarlet Sage

Scarlet Trumpet

Scotch Pinks

Sea Holly.

Sea Lavender

Sea Pink

Sedum .........

Sempervivum

Senna

Service Berry

Shasta Daisy

Sheepherry

Silver Lace Vine.

Silver Lace Vine...........
Snap-dragon $\ldots \ldots \ldots \ldots \ldots \ldots 69$

Sneeze-Wort ................39

Snowball $\ldots \ldots \ldots \ldots \ldots \ldots \ldots \ldots+\ldots$

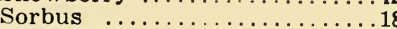

Spearmint $\ldots \ldots \ldots \ldots \ldots \ldots \ldots 63$

Speedwell ....

Spice Bush $\ldots \ldots \ldots \ldots \ldots \ldots \ldots 29$

Spindle Tree $\ldots \ldots \ldots \ldots \ldots \ldots .32$

Spruce ….............23-24

Spurge Japanese ...........63

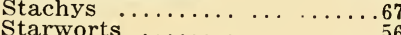

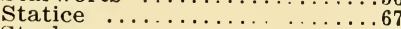

Stocks

Stokesia

Stokes' Aster

Stone Crop

Strawberry Shrub

Strawflower

Sumach

Sunflowers, Hardy

Sweet Alyssum

Sweet Briar

Sweet Gum

Sweet Magnolia

Sweet Pepper Bush.

Sweet Syringa

Sweet Violet

Sweet William

Sycamore

Symphoricarpus

Syringa

Tamarisk

Tamarix

Taxodium

Taxus

(n)

Thorough wort ..............

Thrift ........................

Thunbergia $\ldots \ldots \ldots \ldots \ldots \ldots \ldots 73$

Tiger Lilly . . . . . . . . . . . . . .

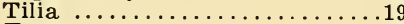

Tomato plants .............. 52

Torch Lily ...................

Tradescantia $\ldots \ldots \ldots \ldots \ldots \ldots 73$

Trillium $\ldots \ldots \ldots \ldots \ldots \ldots \ldots \ldots 67$

Trumpet Vine ................

Tsuga

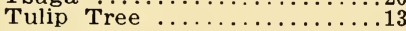

Ulmus $\ldots \ldots \ldots \ldots \ldots \ldots \ldots \ldots$

Umbrella Plant $\ldots \ldots \ldots \ldots \ldots 69$

Umbrella Tree

10

Valerain $\ldots \ldots \ldots \ldots \ldots \ldots \ldots 67$

Valeriana $\ldots \ldots \ldots \ldots \ldots \ldots \ldots 6.67$

Varnish Tree $\ldots \ldots \ldots \ldots \ldots \ldots 13$

Verbena ...................

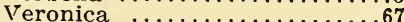

Viburnum $\ldots \ldots \ldots \ldots \ldots \ldots \ldots \ldots \ldots \ldots \ldots \ldots \ldots+45$

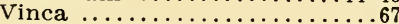

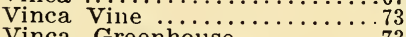

Vinca, Greenhouse ............

Viola $\ldots \ldots \ldots \ldots \ldots \ldots \ldots \ldots \ldots \ldots \ldots \ldots$

Violet, Sweet .............6. 67

Virginia Creeper $\ldots \ldots \ldots \ldots \ldots \ldots 53$
Vitex $\ldots \ldots \ldots \ldots \ldots \ldots \ldots \ldots$

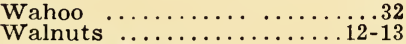

Wandering Jew $\ldots \ldots \ldots \ldots \ldots \ldots .73$

Water Plants .................69

Wayfaring Tree ..............

Weeping Mulberry $\ldots \ldots \ldots \ldots 14$

Weigelia ............. 45-46

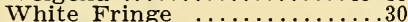

White Kerria $\ldots \ldots \ldots \ldots \ldots \ldots . \cdots \cdots$

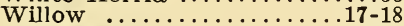

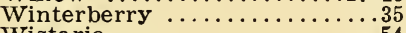

Wistaria $\ldots \ldots \ldots \ldots \ldots \ldots . . \ldots \ldots$

Witch Hazel $\ldots \ldots \ldots \ldots \ldots \ldots .34$

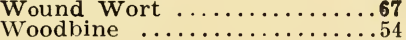

Yarrow .................. 55

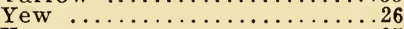

Yucca $\ldots \ldots \ldots \ldots \ldots \ldots \ldots \ldots \ldots \ldots 67$

Zebra Grass $\ldots \ldots \ldots \ldots \ldots \ldots \ldots$
Zinnia $\ldots \ldots \ldots$ 


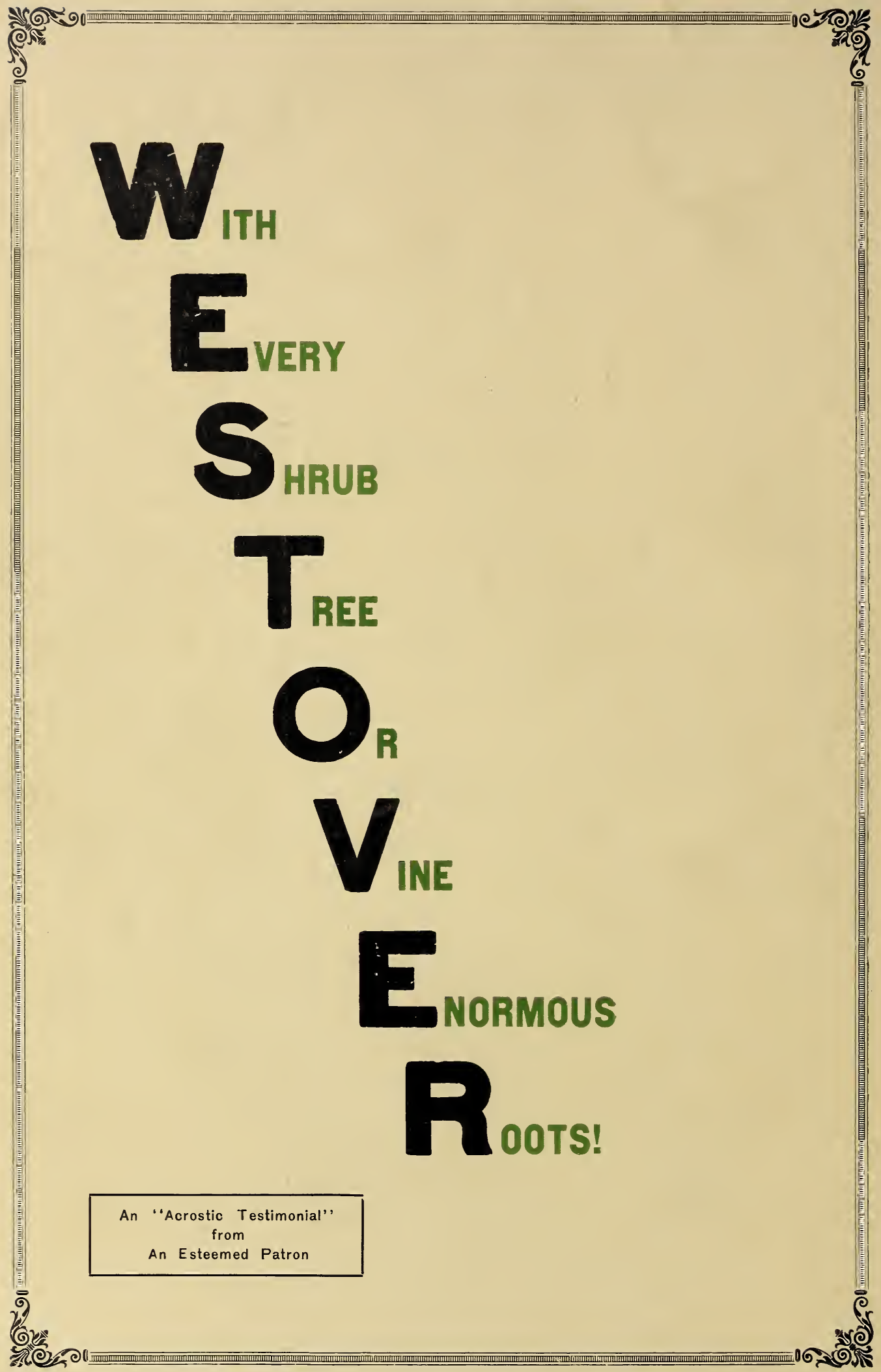

